\title{
NUMÉRO THÉMATIQUE
}

Fonctions exécutives et apprentissages scolaires

\author{
$* * *$ \\ SPECIAL ISSUE \\ Executive Functions and Academic Learning \\ Guest Editors / Directeurs invités \\ PATRICE POTVIN, Ph.D. \\ Université du Québec à Montréal \\ GRÉGOIRE BORST, Ph.D. \\ Université Paris Descartes
}

To cite this issue: Potvin, P., \& Borst, G. (Eds.). (2018). Executive Functions and Academic Learning [Special Issue]. Neuroeducation, 5(2).

Pour citer ce numéro: Potvin, P. et Borst, G. (dir.). (2018). Fonctions exécutives et apprentissages scolaires [Numéro thématique]. Neuroéducation, 5(2).

Issue DOI / DOI du numéro: https://doi.org/10.24046/neuroed.20180502

(C) 2018 - Association for Research in Neuroeducation / Association pour la recherche en neuroéducation 


\title{
INTRODUCTION
}

\section{Executive functions and academic learning}

\author{
Patrice Potvin ${ }^{1 *} \&$ Grégoire Borst ${ }^{2}$
}

\footnotetext{
${ }^{1}$ Université du Québec à Montréal, Faculty of Education Sciences, Department of Didactics, Montreal, Canada

${ }^{2}$ Université Paris Descartes, LaPsyDé, Paris, France

*Author email address: potvin.patrice@uqam.ca
}

To cite this article: Potvin, P., \& Borst, G. (2018). Executive functions and academic learning. Neuroeducation, 5(2), 42-43.

DOI: https://doi.org/10.24046/neuroed.20180502.42

All rights reserved (C) 2018 - Association for Research in Neuroeducation / Association pour la recherche en neuroéducation 
It is increasingly recognized that executive functions (inhibitory control, attention, updating, mental flexibility, reasoning, planning) play an important role in the educational paths of pupils and students. Indeed, learners who present the most developed executive functions are often those who perform and succeed best in school and university. They are also those with the least problems of behavior. However, some studies have also been able to establish convincing links between certain executive functions, which are general in scope, and some more specific difficulties identified by experts in didactics or in special education. Several important questions emerge: How are the EFs involved in such or such disciplinary or specific performance? How can teachers, and more broadly the school systems, take knowledge of EFs into account in their efforts to support learners? Are EFs mere causes of academic learning or can they, in turn, be the effects? Etc.

In this special issue, the Neuroeducation journal has invited researchers to present results of their studies and arguments that are based directly or indirectly on brain functions, and which will provide answers to one or more of these questions.

For example, Marie-Pier Godin, Andréanne Gagné and Nathalie Chapleau, in an article entitled "Phonographic spelling errors in developmental language disorder: Insights from executive functions", present the results of a study conducted on 32 children, some of whom suffered of a language disorder (DLD). The results suggest that some children with DLD have limitations in "updating in working memory", which may lead to slower spelling and more phonographic errors.

For their part, Stella Vosniadou, Dimitrios Pnevmatikos and Nikos Makris, in "The role of executive function in the construction and employment of scientific and mathematical concepts that require conceptual change learning", discuss the general importance of EFs in learning science and mathematics, and particularly in conceptual change processes. Based on their previous research, they illustrate, among other things, the role of inhibition in such processes.

In the results that Bénédicte Willame and Philippe Snauwaert present in their article entitled "Inhibitory control training and chemistry learning in upper secondary education: Fostering a change in conceptual prevalence" (free translation), convincing experimental evidence suggests that training courses designed to generate cognitive conflicts and train the learners in inhibitory control can have positive effects on the learning of chemistry concepts.

In an analysis of "Theoretical perspectives on executive functions in educational context in preschool children" (free translation), Stéphanie Duval, Noémie Montminy and Aimée Gaudette-Leblanc document the evolution of the theoretical considerations that nourish our understanding of the development of executive functions for children aged between 3 and 6 and come up with options for supporting EF skills at the preschool level.
Reuven Babai, Eldad Cohen and Ruth Stavy then present the results of an experimental study of proportional reasoning that compares the measurements obtained with two similar visual tasks that differ in that only one reduces the interference due to comparison of the numbers making up proportionality ratios. The article, titled "Proportional reasoning: Reducing the interference of natural numbers through an intervention based on the problem-solving framework of executive functions", suggests that modes of representation or the order of their presentation may have implications on the learning of proportionality.

And finally, François Thibault and Patrice Potvin, in "Executive function as a predictor of physics-related conceptual change", present the results of an experimental research of which data support the hypothesis that the engineering students who present the best EFs are also those who, more often, will undergo conceptual changes during university courses in mechanics.

In the end, this special issue brings an unprecedented and convincing light on the links initially presumed between executive functions and academic learning. It illustrates how particular EFs seem to intervene in the resolution of distinct problems that come from disciplines that are often very different. It also allows catching a glimpse of the constraints and the hopes that could raise a possible education of executive functions. 
INTRODUCTION

\title{
Fonctions exécutives et apprentissages scolaires
}

\author{
Patrice Potvin $^{1 *}$ et Grégoire Borst ${ }^{2}$
}

\footnotetext{
${ }^{1}$ Université du Québec à Montréal, Faculté des sciences de l'éducation, Département de didactique, Montréal, Canada

${ }^{2}$ Université Paris Descartes, LaPsyDé, Paris, France

*Correspondance avec l'auteur : potvin.patrice@uqam.ca
}

Pour citer cet article: Potvin, P. et Borst, G. (2018). Fonctions exécutives et apprentissages scolaires. Neuroéducation, 5(2), 44-45.

DOI: https://doi.org/10.24046/neuroed.20180502.44

Publié en ligne le 19 septembre 2018.

Neuroéducation, 5(2), 44-45

ISSN: 1929-1833

Tous droits réservés (C) 2018 - Association pour la recherche en neuroéducation / Association for Research in Neuroeducation 
Il est de plus en plus reconnu que les fonctions exécutives (FÉ; contrôle inhibiteur, attention, mise à jour [updating], flexibilité mentale, raisonnement, planification) jouent un rôle important dans le parcours scolaire des élèves et des étudiants. En effet, les apprenants qui présentent les fonctions exécutives les mieux développées sont souvent ceux qui performent et réussissent le mieux à l'école et à l'université. Ce sont aussi ceux qui présentent le moins de problèmes de comportement. Mais certains travaux de recherche ont également pu établir des liens convaincants entre certaines fonctions exécutives, à la portée pourtant générale, et certaines difficultés plus spécifiques qu'ont identifiées les didacticiens ou les spécialistes de l'adaptation scolaire. Plusieurs questions importantes émergent alors : Quelles sont les FÉ impliqués dans telle ou telle performance disciplinaire ou spécifique? Comment les enseignants, et plus largement le système scolaire, peuvent-ils tenir compte des connaissances portant sur les FÉ dans les efforts qu'ils déploient pour soutenir les apprenants? Les FÉ ne sont-elles que des causes de l'apprentissage scolaire ou peuvent-elles aussi, en retour, en être les effets? Etc.

Dans ce numéro spécial, la revue Neuroéducation a invité les chercheurs à présenter des résultats de recherche et des argumentaires qui sont basés directement ou indirectement sur le fonctionnement du cerveau, et qui permettront d'apporter des éléments de réponse à une ou plusieurs de ces questions.

Ainsi, par exemple, Marie-Pier Godin, Andréanne Gagné et Nathalie Chapleau, dans un article intitulé «Phonographic spelling errors in developmental language disorder: Insights from executive functions », présentent les résultats d'une étude menée sur 32 enfants, dont certains souffraient d'un trouble de langage (DLD). Les résultats semblent indiquer que certains enfants atteints de DLD présentent des limitations dans la « mise à jour en mémoire de travail » (updating), ce qui peut entraîner une acquisition plus lente de l'orthographe et causer un plus grand nombre d'erreurs phonographiques.

Stella Vosniadou, Dimitrios Pnevmatikos et Nikos Makris, dans « The role of executive function in the construction and employment of scientific and mathematical concepts that require conceptual change learning », animent quant à eux une discussion sur l'importance générale des FÉ dans l'apprentissage des sciences et des mathématiques, et en particulier dans les processus de changement conceptuel. En s'appuyant sur leurs recherches antérieures, ils illustrent, entre autres, le rôle de l'inhibition dans de tels processus.

Dans les résultats que Bénédicte Willame et Philippe Snauwaert présentent dans leur article intitulé «Entraînement au contrôle inhibiteur et apprentissage en chimie dans le secondaire supérieur: Favoriser un changement de prévalence conceptuelle », on peut trouver une preuve expérimentale convaincante à l'effet que des dispositifs de formation destinés à générer des conflits cognitifs et entraîner les apprenants au contrôle inhibiteur peuvent avoir des effets positifs sur l'apprentissage de concepts de chimie.
Dans une analyse des «Perspectives théoriques à l'égard des fonctions exécutives en contexte éducatif chez les enfants d'âge préscolaire », Stéphanie Duval, Noémie Montminy et Aimée Gaudette-Leblanc documentent quant à elles l'évolution des considérations théoriques qui nourrissent notre compréhension du développement des fonctions exécutives chez les enfants âgés entre 3 et 6 ans et en viennent à proposer des pistes d'intervention permettant de soutenir les habiletés liées aux FÉ au préscolaire.

Par la suite, Reuven Babai, Eldad Cohen et Ruth Stavy présentent les résultats d'une étude expérimentale sur le raisonnement proportionnel qui compare les mesures obtenues à deux tâches visuelles semblables mais qui diffèrent en ce qu'une seule réduit l'interférence due à la comparaison des nombres composant les rapports de proportionnalité. L'article, intitulé « Proportional reasoning: Reducing the interference of natural numbers through an intervention based on the problem-solving framework of executive functions 》, en vient à suggérer que les modes de représentation ou l'ordre de leur présentation peuvent avoir des incidences sur l'apprentissage de la proportionnalité.

Et finalement, François Thibault et Patrice Potvin, dans leur article «Executive function as a predictor of physics-related conceptual change » présentent les résultats d'une recherche expérimentale dont les données appuient l'hypothèse selon laquelle les étudiants en génie qui présentent les meilleures FÉ sont aussi ceux qui, plus souvent, vont vivre des changements conceptuels lors de cours de formation universitaire en mécanique.

En définitive, ce numéro thématique apporte un éclairage inédit et convaincant sur les liens initialement présumés entre les $F E ́$ et les apprentissages scolaires. Il permet d'illustrer comment certaines FÉ semblent intervenir dans la résolution de problèmes distincts et provenant de disciplines qui sont pourtant très différentes. Il permet aussi d'entrevoir les contraintes et les espoirs que pourrait soulever une éventuelle éducation aux fonctions exécutives. 


\title{
Phonographic spelling errors in developmental language disorder: Insights from executive functions
}

\author{
Marie-Pier Godin $^{1 *}$, Andréanne Gagné ${ }^{1}$, Nathalie Chapleau ${ }^{2}$
}

\begin{abstract}
The present study examined the executive functions and spelling performance of children with developmental language disorder (DLD) over a school year. Through a fine-grained spelling error analysis, we investigated whether the measured executive functions would distinguish children's spelling profiles. The study comprised three groups: the DLD-S group (aged 7-9 years), including children with DLD matched on the total number of spelling errors produced on a dictation task with a typically developing group $(n=8)$; the DLD-AM group (aged 79 years), including children with DLD matched on chronological age and phonological awareness skills with the DLD-S group $(n=8)$; and the typically developing group $(n=16$; aged 7-8 years). The results indicated that both DLD groups tended to produce more phonographic errors (i.e., spelling errors that change the phonology of the word) even if the DLD-S group produced a similar number of errors in comparison with the typically developing group. In particular, the DLD-AM group made more phoneme omissions than the other groups. The DLD-AM group also had the smallest spelling improvement over the school year and the weakest updating ability. In contrast, all groups had similar inhibition and cognitive flexibility abilities. This may indicate that some children with DLD present limitations in updating, which may lead to a slower spelling acquisition and a greater number of phonographic errors. Language impairments affect and delay spelling acquisition, and the presence of an updating deficit may exacerbate this delay.
\end{abstract}

\footnotetext{
${ }^{1}$ Université du Québec à Montréal, Faculty of Education Sciences, Department of Language Didactics, Montreal, Canada

${ }^{2}$ Université du Québec à Montréal, Faculty of Education Sciences, Department of Specialized Education and Training

*Author email address: godin.marie-pier@uqam.ca
}

To cite this article: Godin, M.-P., Gagné, A., \& Chapleau, N. (2018). Phonographic spelling errors in developmental language disorder: Insights from executive functions. Neuroeducation, 5(2), 46-61.

DOI: https://doi.org/10.24046/neuroed.20180502.46

Received on November $1^{\text {st }}, 2017$. Received in revised form on April $28^{\text {th }}, 2018$.

Accepted on May $10^{\text {th }}, 2018$. Available online on September $19^{\text {th }}, 2018$.

Neuroeducation, 5(2), 46-61

ISSN: 1929-1833

All rights reserved (C) 2018 - Association for Research in Neuroeducation 


\section{Introduction}

Developmental language disorder (DLD), formerly called specific language impairment (SLI), refers to a disorder affecting oral language despite the absence of a mental or physical handicap, hearing impairment, or environmental deprivation (Bishop et al., 2017; Bishop et al., 2016; Leonard, 2014). It is generally acknowledged that language impairments are associated with difficulties in literacy acquisition (Bishop \& Adams, 1990; Nash et al., 2013). There is also growing evidence that executive functioning (EF) may be involved in the problems characterizing language impairments and could be affected in children with DLD (Henry, Messer, \& Nash, 2011; Montgomery, Magimairaj, \& Finney, 2010; Pauls \& Archibald, 2016). The components of EF, or executive functions (EFs), are described as a set of higher order cognitive processes responsible for purposeful and goaldirected behaviours (Jurado \& Rosselli, 2007; Miyake et al., 2000). EFs are generally associated with writing performance (Altemeier et al., 2006; Berninger, Garcia, \& Abbott, 2009; Drijbooms, Groen, \& Verhoeven, 2015; Hooper et al., 2002; Roebers \& Jäger, 2014) and could discriminate skilled from less skilled spellers (Altemeier, Abbott, \& Berninger, 2008; Altemeier et al., 2006; Roebers \& Jäger, 2014; Walda et al., 2014). However, research on EFs and spelling acquisition in children with DLD is still limited.

\subsection{Executive functions in children with DLD}

Three of the most frequently identified EF components are inhibition, cognitive flexibility, and updating (Diamond, 2013; Miyake et al., 2000). Inhibition is the ability to stop prepotent or ongoing responses (Ibid.), whereas cognitive flexibility, also referred to as shifting, represents the ability to switch or adapt the focus of attention between tasks or problemsolving strategies (Miyake \& Friedman, 2012; Miyake et al., 2000). As for updating, it refers to the ability to monitor and code task-relevant incoming information. Updating also involves mentally working with information held in mind (Best, Miller, \& Jones, 2009; Diamond, 2013; Miyake et al., 2000).

Previous studies have shown inconsistent results regarding inhibition deficits in children with DLD. Some studies (Bishop \& Norbury, 2005; Ebert \& Kohnert, 2011; Finneran, Francis, \& Leonard, 2009; Henry et al., 2011; Pauls \& Archibald, 2016; Spaulding, 2010) pointed out difficulties in children with DLD compared to their typically developing (TD) peers, whereas other studies (Hanson \& Montgomery, 2002; Lukács et al., 2016; Marton et al., 2012; Noterdaeme et al., 2001) did not demonstrate differences between these groups. This divergence could be due to the various tasks used to measure inhibition (Pauls \& Archibald, 2016). Many of these tasks involved language, and it becomes difficult to dissociate language impairments from inhibition deficits.

Inconsistent results have also been observed regarding cognitive flexibility deficits. Some studies pointed out difficulties in children with DLD in comparison with TD children, specifically for tasks involving multivalent stimuli and multiple dimensional shifts (Marton, 2008; Vugs et al., 2013; Weyandt \& Willis, 1994). In contrast, other studies did not show that cognitive flexibility was deficient in children with DLD (Dibbets, Bakker, \& Jolles, 2006; Henry et al., 2011; Im-Bolter, Johnson, \& Pascual-Leone, 2006). As shown by Pauls and Archibald's (2016) meta-analysis, most of the tasks used to assess cognitive flexibility included verbal demands, and differences between DLD and TD children, if any, were probably due to language impairments.

Studies on children with DLD have focused more on updating given the strong links between working memory, language, and phonological skills (Montgomery, 2002; Montgomery et al., 2010). Many studies (e.g., Archibald \& Gathercole, 2006, 2007; Archibald \& Joanisse, 2009; Botting \& Conti-Ramsden, 2001; Graf Estes, Evans, \& Else-Quest, 2007; Montgomery et al., 2010) have shown important phonological loop limitations in the working memory in children with DLD. This phonological loop refers to the ability to temporarily store verbal information and it is generally measured by nonword repetition tasks (Montgomery et al., 2010). A recent metaanalysis (Vugs et al., 2013) has shown that working memory deficits may extend to the visuospatial domain. However, difficulties not only appear in the ability to temporarily store information, but also in its manipulation. In fact, in the DLD population, many children exhibit limitations in updating (Archibald \& Gathercole, 2006, 2007; Archibald, Joanisse, \& Edmunds, 2011; Bishop, 2006; Henry et al., 2011; Im-Bolter et al., 2006; Marton, 2008; Montgomery et al., 2010). Nonetheless, not all children with DLD present updating limitations (Archibald \& Joanisse, 2009). Considering that EF supports spelling, it would be relevant to examine the spelling development and the different spelling profiles of children with DLD, and to determine whether these profiles are only driven by their language abilities or by their EF as well. Before explaining the links between EF and spelling, spelling performance in children with DLD will be presented.

\subsection{Spelling in children with DLD}

Many studies pointed out that children with DLD are highly at risk of developing spelling delays (e.g., Cordewener, Bosman, \& Verhoeven, 2012; Nauclér, 2004; Snowling, Bishop, \& Stothard, 2000). Children with DLD generally produce more spelling errors than their TD peers with the same chronological age (e.g., Broc et al., 2013; Cordewener et al., 2012; Nauclér, 2004; Larkin, Williams, \& Blaggan, 2013). However, little is known about the error types produced. It is therefore difficult to confirm whether the error types made by DLD children are similar to or different from those made by TD children. Furthermore, few studies on children with DLD have examined spelling skills from a developmental perspective (e.g., Cordewener et al., 2012; Nauclér, 2004). Using one-time measurements does not allow for examining the evolution of the error types produced. In contrast, a longitudinal data collection contributes to a better understanding of the delay 
in spelling acquisition in the DLD population. To our knowledge, no study has examined French spelling acquisition in a longitudinal manner in children with DLD.

In order to better understand French spelling acquisition, it is important to note that French orthography is based on transcribing phonemes into graphemes (Jaffré \& Fayol, 2006; Perfetti, 1997). Oral language abilities and, more precisely, phonological skills are crucial for a good phonographic information transcription. In French, the writing system is coded with phonographic, orthographic, and morphographic information (Jaffré \& Fayol, 2006), but, this manuscript only focuses on the phonographic dimension.

Previous studies showed that children with DLD tend to produce more phonographic errors (i.e., phonologically unacceptable errors) than their TD peers (Bishop \& Clarkson, 2003; Broc et al., 2013; Larkin et al., 2014; Larkin \& Snowling, 2008; Nauclér, 2004), and more phonographic errors than younger children matched on spelling age (Larkin et al., 2013), on reading age (Larking \& Snowling, 2008), or on vocabulary level (Bishop \& Clarkson, 2003). Phonographic errors are spelling productions that change the phonology of the word. In contrast, TD children tend to produce more orthographic errors (i.e., phonologically acceptable errors), in which incorrect but plausible graphemes represent the phonology of the word. For example, in English, for the word card, an orthographic error could be kard, whereas a phonographic error could be gard. In French, for the word chaise $/ \int \varepsilon z /$, an orthographic error could be *chaize $/ \int \varepsilon z /$, and *chège $/ \int \varepsilon 3 /$ would be a phonographic error.

Phonographic errors are generally associated with weak or immature phonological awareness skills (Bishop \& Clarkson 2003). These errors tend to persist in the productions of children with DLD until adolescence (Nauclér, 2004). Some studies (Bishop \& Clarkson, 2003; Brizzolara et al., 2011; Larkin \& Snowling, 2008) hypothesize that an updating capacity deficit could also explain these phonographic errors in children with DLD, but no analysis was done to confirm this hypothesis. Observed types of phonographic errors include phoneme substitutions, omissions, and additions (Apel \& Masterson, 2001; Fayol, 2008; Masterson \& Apel, 2000, 2010). Only a single study (Nauclér, 2004) has examined these error types in the phonographic dimension in children with DLD, and it targeted Swedish language. However, it is important to note that some studies (e.g., Mackie \& Dockrell, 2004; Mackie, Dockrell, \& Lindsay, 2012; Silliman, Bahr, \& Peters, 2006) observed omissions, but in the morphographic dimension. These studies show that children with DLD tend to omit more frequently inflectional morphemes in their spelling attempts (e.g. the regular past tense morpheme -ed, the progressive ing morpheme, or the third person singular form - s). In sum, a limited number of studies have observed phonographic error types in children with DLD, and none of them in French. Consequently, spelling performance comprehension in the phonographic dimension is limited. Phonographic errors are generally associated to weak phonological awareness skills (Bishop \& Clarkson, 2003), but some studies (Bishop \&
Clarkson, 2003; Brizzolara et al., 2011; Larkin \& Snowling, 2008) suggest that they could also be associated to updating deficits - an EF component.

\subsection{Links between executive functions and spelling}

EF abilities are responsible for directing, adapting, switching, and monitoring tasks (Miyake et al. 2000), and contribute to writing and spelling productions (Altemeier et al., 2006; Åsberg Johnels, Kopp, \& Gillberg, 2014; Berninger et al., 2009). Most studies examining EF components and their links with spelling analyzed written language skills in a general manner (Hooper et al., 2010; Roebers \& Jäger, 2014; Röthlisberger et al., 2013), and showed that inhibition and cognitive flexibility explained variance in reading and writing performance (Altemeier et al., 2008) without describing each component's role. Nonetheless, few studies established links between each component and spelling acquisition.

With regard to spelling acquisition, inhibition and cognitive flexibility have received substantially less attention in research than updating. Studies suggest that inhibition capacity could suppress irrelevant information, such as phoneme or grapheme representations, and allow for an efficient retrieval of the relevant representations from longterm memory (Altemeier et al., 2008; Kellogg et al., 2013; Ribaupierre, 2002). In contrast, cognitive flexibility allows for switching from an inhibited representation set to an activated one (Kellogg et al., 2013).

Updating capacity plays a central role in the writing process (Berninger et al., 2009) and is involved in spelling acquisition (Caravolas, Hulme, \& Snowling, 2001; Lervåg \& Hulme, 2010; Stage \& Wagner, 1992). Updating enables spellers to maintain phoneme sequences in working memory and to keep track of the accurate and correctly ordered correspondences between phonemes and graphemes. Consequently, spelling represents a heavy processing task for working memory (Lervåg \& Hulme, 2010) and EFs appear to be involved in spelling acquisition. If this set of EF abilities fails, spelling is hampered, and it could also lead to a greater proportion of phonographic errors (Bishop \& Clarkson, 2003; Brizzolara et al., 2011; Larkin \& Snowling, 2008).

To our knowledge, no studies on children with DLD have tried to establish spelling profiles in the phonographic dimension and to examine EF in these different profiles, although several studies pointed out a delay in spelling acquisition (e.g., Cordewener et al., 2012; Nauclér, 2004; Snowling et al., 2000). Language impairments could explain this delay, but limitations in EF could as well. By comparing different groups of children with DLD who have similar language abilities, and by examining more closely the error types, it is possible to determine whether there is a difference in EF components between the DLD groups and whether it corresponds to a difference in spelling profiles. In combination with a longitudinal design, it may also be possible to compare the evolution of spelling skills and find out which abilities underlie the spelling delay of children with DLD. 


\subsection{The present study}

The present study examined the EF and spelling performance of children with DLD throughout a school year. The study comprised three groups: (a) DLD children matched on the total number of spelling errors produced on a dictation task with TD children; (b) DLD children matched with the other DLD children on chronological age and phonological awareness skills but producing a greater number of spelling errors; and (c) TD children. Outlined below are the four goals of this study.

Our first goal was to examine and compare EF between the three groups: Do the measured EF components differ between groups depending on their language abilities and spelling skills? We predicted that both DLD groups would perform similarly to TD children on cognitive flexibility and inhibition tasks based on previous studies (e.g., Dibbets et al., 2006; Finneran et al., 2009; Hanson \& Montgomery, 2002; Henry et al., 2011; Im-Bolter et al., 2006). However, we expected that both DLD groups would have lower scores than TD children on the updating measure (Archibald et al., 2011; Bishop, 2006; Montgomery et al., 2010), but that differences would be found between the DLD groups (Archibald \& Joanisse, 2009), with weaker spellers having weaker updating abilities (Bishop \& Clarkson, 2003; Larkin \& Snowling, 2008; Roebers \& Jäger, 2014).

Our second goal was to compare the evolution of spelling performance throughout the school year between the three groups: Does spelling performance evolve differently between groups in terms of the number of spelling errors produced? Based on their language abilities, we expected that TD children would make greater and faster progress in spelling than the two DLD groups.

Our third goal was to compare the proportions of phonographic errors between the three groups: Regardless of their differences in spelling performance, do the groups differ in the proportion of phonographic errors made? Based on previous studies (Larkin \& Snowling, 2008; Larkin et al., 2013; Nauclér, 2004), we predicted that both DLD groups would produce phonographic errors in greater proportion than their TD peers.

Our last goal was twofold. First, we wanted to examine the types of phonographic errors made by each group based on a fine-grained coding system. Second, we aimed to determine whether the observed patterns of phonographic errors differed between the three groups: Do spelling error patterns emerge in each group and if so, do they differ between groups? We predicted that the phonographic errors made by TD children would most likely be phoneme substitutions. In contrast, we hypothesized that both DLD groups would produce a wider range of error types (i.e., phoneme substitutions, omissions, and additions), which would reflect their inaccurate and unstable phonological representations (Zourou et al., 2010).
In sum, these group comparisons are relevant in two main respects. First, comparing TD children and peers with DLD who make a comparable number of spelling errors allows to determine whether the spelling errors are qualitatively similar between these groups. Second, a comparison between two DLD groups of the same chronological age and with similar phonological awareness skills also allows to observe potential qualitative differences in spelling errors. Importantly, this comparison enables us to observe whether the weaker spellers have weaker EF abilities.

\section{Method}

\subsection{Participants}

The 32 participants attended French schools in the suburbs of Montreal, Quebec, Canada, and had French as their first language. On the Test of Nonverbal Intelligence (TONI-3: Brown, Sherbenou, \& Johnsen, 1997), they all obtained scores within normal limits (i.e., standard scores above 85). All participants were in second grade and none received an intensive training on spelling. According to the teachers, around one hour per week was devoted to spelling. Half were children with DLD, and the other half were TD children. Children with DLD were further divided into two groups of eight participants based on the number of spelling errors produced on a dictation task (the DLD-S and DLD-AM groups). Descriptive statistics are presented in Table 1.

\section{Children with DLD}

In the province of Quebec, many students with DLD attend special language classes (ministère de l'Éducation, du Loisir et $\mathrm{du}$ Sport, 2008) and receive specialized instruction in groups smaller than those in mainstream education. Our sample consisted of 16 children (3 girls, 13 boys) who attended a special language class. Only children with a diagnosis of DLD made by a speech-language pathologist were included. Two had also been diagnosed with childhood apraxia of speech (CAS). Deaf and hearing-impaired children, as well as children with attention deficit hyperactivity disorder (ADHD) and autism syndrome disorder (ASD), were excluded from this study.

As shown in Table 1, the DLD-S and DLD-AM groups were matched on chronological age and phonological awareness skills but differed in the total number of spelling errors produced on an experimental dictation, with the DLD-S group performing significantly better on this dictation and producing less errors. The DLD-S group was matched with the TD group on the total number of spelling errors produced on the experimental dictation. No match on gender was done.

\section{TD children}

The 16 TD children were recruited from mainstream classrooms. This sample consisted of eight girls and eight boys, none of whom had been diagnosed with any learning disability. As mentioned, this group was matched with the DLD-S group on the total number of spelling errors produced on the experimental dictation. TD children had significantly higher scores on the phonological awareness task than both DLD groups. 
Table 1. Median $(\mathrm{M} d n)$ and range of ages, standardized measures, and performance on the experimental dictation for the three participant groups.

\begin{tabular}{|c|c|c|c|c|c|c|c|c|}
\hline \multirow[t]{2}{*}{ Measures } & \multicolumn{2}{|c|}{$\begin{array}{c}\text { TD } \\
(n=16)\end{array}$} & \multicolumn{2}{|c|}{$\begin{array}{l}\text { DLD-S } \\
(n=8)\end{array}$} & \multicolumn{2}{|c|}{$\begin{array}{l}\text { DLD-AM } \\
(n=8)\end{array}$} & \multicolumn{2}{|c|}{$\begin{array}{c}\text { Group } \\
\text { comparison }\end{array}$} \\
\hline & $\mathrm{Mdn}$ & range & $\mathrm{Mdn}$ & range & $\mathrm{Mdn}$ & range & $\chi^{2}(2)$ & $p$ \\
\hline $\begin{array}{l}\text { Chronological age } \\
\text { (years; months) }\end{array}$ & $7 ; 08_{a}$ & $7 ; 02-8 ; 03$ & $8 ; 05$ & $7 ; 04-9 ; 00$ & $8 ; 07_{b}$ & $7 ; 04-9 ; 03$ & 10.5 & .005 \\
\hline $\begin{array}{l}\text { Nonverbal intelligence } \\
\text { (TONI-3, standard score) }\end{array}$ & $97.0_{a}$ & $85.0-124$ & 92.5 & $85.0-100$ & $87.0_{\mathrm{b}}$ & $85.0-97.0$ & 11.7 & .001 \\
\hline $\begin{array}{l}\text { Phonological awareness } \\
\text { (CELF-CDN-F) }\end{array}$ & $63.0_{a}$ & $49.0-76.0$ & $45.5_{\mathrm{b}}$ & $30.0-67.0$ & $44.5_{\mathrm{b}}$ & $38.0-57.0$ & 13.4 & .001 \\
\hline $\begin{array}{l}\text { Spelling skills } \\
\text { Experimental dictation } \\
\text { (number of errors) }\end{array}$ & $38.0_{a}$ & $18.0-55.0$ & $41.5 \mathrm{a}$ & $20.0-52.0$ & $53.5_{b}$ & $49.0-70.0$ & 12.9 & .002 \\
\hline
\end{tabular}

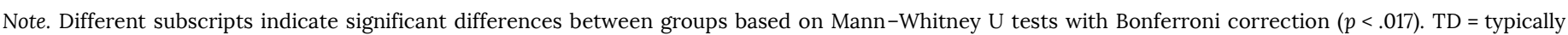

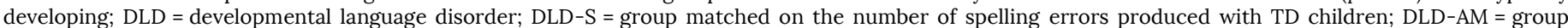

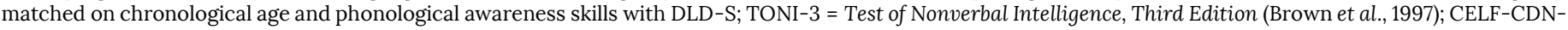
$\mathrm{F}=$ French Canadian version of the Clinical Evaluation of Language Fundamentals, Fourth Edition (Wiig et al., 2009).

\subsection{Measures}

Nonverbal intelligence and phonological awareness

Nonverbal intelligence and phonological awareness were assessed using standardized tests and used as control measures. The tests were administered and scored according to the procedures outlined in the test manuals. To assess nonverbal intelligence, the TONI-3 (Brown et al., 1997) was used. This language-free test measures intelligence, abstract reasoning, and problem solving. To assess phonological awareness skills, the Phonological Awareness subtest from the French-Canadian version of the Clinical Evaluation of Language Fundamentals, Fourth Edition (CELF-CDN-FR: Wiig et al., 2009) was used. Participants were administered 11 graduated tasks of syllable and phoneme manipulations. The test ended when participants failed all the items in a task or succeeded only once during three consecutive tasks.

Executive functions

Three EF components were assessed: updating, cognitive flexibility, and inhibition. All standardized tests corresponded to the participants' age range and were administered according to the procedures in the manuals. To assess updating capacity, the Digit Recall subtest from the French version of the Children's Memory Scale (CMS: Cohen, 2001) was used. There were two parts in this test, and two practice items were given before each part. In the first part, participants were asked to repeat digit strings forward. The first two strings contained two digits, the following two contained three digits, and so on, up to a maximum of nine digits. One point was given for each correctly repeated string (max. 18 points). This part ended when participants failed two consecutive items with the same number of digits. The second part of the test consisted in repeating digit strings backward. This part followed the same procedure as the first one, except that the maximum string length was eight digits, for a maximum of 16 points. On the one hand, the first part of this task measured more specifically the ability to temporarily store verbal information (i.e. the phonological loop). On the other hand, the second part targeted the capacity to maintain and manipulate verbal information held in mind, which is more in line with verbal working memory and updating capacities. A total score (max. 34 points) and subtotals for the two parts were obtained.

To assess cognitive flexibility, the Animal Sorting subtest from the French version of the Developmental Neuropsychological Assessment, Second Edition (NEPSY-II: Korkman, Kirk, \& Kemp, 2012) was used. In this test, participants were asked to sort eight picture cards of animals into two groups of four. No reading or expressive language was required to complete the task. In six minutes, participants had to do as many different sorts as possible. The number of correct sorts and the number of errors were counted.

Finally, to assess inhibition capacity, the Walk Don't Walk subtest from the French version of the Test of Everyday Attention for Children (TEA-Ch: Manly et al., 1999) was used. On a sheet showing paths made up of footprints, participants had to move their pencil one step upon hearing a sound stimulus (the go tone). However, they had to stop if this stimulus was followed by an explosion noise (the no-go tone). The items included three to twelve steps, and the pace increased throughout the task. The test began with four practice items, followed by twenty test items. One point was given for each correctly inhibited sequence (max. 20 points). 
Spelling

To assess spelling skills, an experimental dictation was used. This dictation consisted of 45 isolated words including 11 frequent words, 10 regular words, 14 words with complex or contextual graphemes, and 10 words with a final silent letter. All items were selected based on oral and written frequencies from three lexical databases (i.e., MANULEX: Lété, SprengerCharolles, \& Colé, 2004; ÉOLE: Pothier \& Pothier, 2004; Échelle de vocabulaire oral de Préfontaine: Préfontaine \& Préfontaine, 1968). These databases provide word frequencies on a grade-level basis, and all chosen items were of equivalent Grade 2 frequencies. Items were presented in a random order at each time of measurement. The experimenter said the target word, then said it in a sentence, and then repeated it again in isolation (e.g., Girafe. Mon animal préféré est la girafe. Girafe. [Giraffe. My favourite animal is the giraffe. Giraffe.]). The number of spelling errors was calculated.

To determine if qualitative differences in spelling errors were evident between groups, each error from the experimental dictation was coded. A fine-grained coding system inspired by previous studies (Fayol, 2008; Masterson \& Apel, 2000, 2010) was used. Such an approach allows to examine linguistic factors that lead to different spelling error types (Fayol, 2008; Masterson \& Apel 2000, 2010). Spelling errors were divided into phonographic and orthographic errors. As a reminder, phonographic errors are spelling productions that change the phonology of the word, whereas orthographic errors contain incorrect but plausible graphemes that represent the phonology of the word. In the present study, we examined the types of phonographic errors made by children. Three types of phonographic errors were distinguished: phoneme substitution, phoneme omission, and phoneme addition. Examples for each of them are provided in Table 2. A spelling error could be associated with only one type of phonographic error. Percentages of phonographic errors (among all spelling errors) and phonographic error types (among all phonographic errors) were calculated to examine how participants differed in the proportion of phonographic errors made, and to deeply analyze qualitative differences between groups in phonographic terms.

Table 2. Fine-grained analysis of phonographic spelling errors

\begin{tabular}{ll}
\hline $\begin{array}{l}\text { Type of } \\
\text { phonographic } \\
\text { error }\end{array}$ & Description \\
\hline $\begin{array}{l}\text { Phoneme } \\
\text { substitution }\end{array}$ & $\begin{array}{l}\text { Spellings with a sound substituted by another } \\
\left.\text { (e.g., chaise }- \text { chège; } / \int \varepsilon z / \rightarrow / \int \varepsilon z /\right) .\end{array}$ \\
$\begin{array}{l}\text { Phoneme } \\
\text { omission }\end{array}$ & $\begin{array}{l}\text { Spellings with a sound omitted } \\
\left.\text { (e.g., chaise }- \text { chè; } / \int \varepsilon z / \rightarrow / \int \varepsilon /\right) .\end{array}$ \\
$\begin{array}{l}\text { Phoneme } \\
\text { addition }\end{array}$ & $\begin{array}{l}\text { Spellings with a sound added } \\
(\text { e.g., sortir }- \text { soritir; } / \text { SortiR } / \rightarrow / \text { soRitiR } /) .\end{array}$ \\
\hline
\end{tabular}

\subsection{Procedure}

All children participated with parental consent and were tested three times during the school year: in November (T1), February (T2), and May (T3). For control measures (nonverbal intelligence and phonological awareness) and for EF measures, each child was tested individually during two 45minute sessions in a separate room at T1. The experimental dictation was group-administered in classrooms at the three time points to examine the evolution of spelling performance. At each time point, this spelling test was administered in two sessions and word items were randomly listed to decrease the risk of a habituation effect. No feedback was provided to the students on the words after the dictations.

\section{Results}

Nonparametric tests were used to compare the three groups because of the small sample sizes. The Kruskal-Wallis test, the Mann-Whitney U test, and Friedman's ANOVA were used to provide comparisons between and within groups. A Bonferroni correction was applied when necessary. It is important to mention that the DLD-AM children obtained scores within normal limits for nonverbal intelligence (as seen in Table 1), but that they had a significantly lower score than those from the TD group. Therefore, comparisons between these two groups must be interpreted with great caution, considering that nonverbal intelligence may explain differences in other aspects of cognition and spelling performance.

\subsection{Executive functions}

To address our first research question and compare the three groups on their EF abilities, a series of Kruskal-Wallis tests were used. Mann-Whitney $U$ tests with Bonferroni correction $(p<.017)$ were applied to follow up significant results. Median scores and group comparisons are displayed in Table 3.

For the updating measure (total), a significant difference was found between the three groups. Mann-Whitney $U$ tests showed a significant difference between the TD and DLD-AM groups, $U=14.3, p<.001, r=.69$. No significant difference was noted between the TD and DLD-S groups, $U=4.84, p=.227$, $r=.28$. The difference between the two DLD groups was not significant, $U=9.44, p=.042, r=.58$. However, given the large effect size, a larger sample could lead to a significant difference between the two DLD groups.

These differences between groups were maintained on both parts of the updating task (repeating digits forward or backward). TD children had significantly higher median scores than the DLD-AM group on the forward subtask, $\mathrm{U}=10.6, p=.006, r=.54$, and on the backward subtask, $\mathrm{U}=12.8, p=.001, r=.63$. No significant differences between the TD and DLD-S groups were observed on the forward subtask, $U=4.63, p=.236, r=.25$, and on the backward subtask, $\mathrm{U}=3.53, p=.369, r=.23$. The two DLD groups did 
not differ significantly on the forward subtask, $U=6.00$, $p=.183, r=.36$, and on the backward subtask, $U=9.31$, $p=.040, r=.63$. However, these medium and large effect sizes indicated that the differences between the two DLD groups could be significant with a larger sample. The three groups differed only on the updating measure. No significant differences were found between groups on the cognitive flexibility and inhibition measures. Whereas all groups performed similarly on the cognitive flexibility and inhibition tasks, the DLD-AM group had significantly lower performance on both parts of the updating task.

Table 3. Median $(\mathrm{Mdn})$ and range of executive function measures for the three participant groups

\begin{tabular}{|c|c|c|c|c|c|c|c|c|}
\hline \multirow{2}{*}{$\begin{array}{l}\text { Executive function } \\
\text { measures }\end{array}$} & \multicolumn{2}{|c|}{$\begin{array}{c}\text { TD } \\
(n=16)\end{array}$} & \multicolumn{2}{|c|}{$\begin{array}{l}\text { DLD-S } \\
(n=8)\end{array}$} & \multicolumn{2}{|c|}{$\begin{array}{l}\text { DLD-AM } \\
(n=8)\end{array}$} & \multicolumn{2}{|c|}{$\begin{array}{c}\text { Group } \\
\text { comparisons }\end{array}$} \\
\hline & $\mathrm{Mdn}$ & range & $\mathrm{Mdn}$ & range & $\mathrm{Mdn}$ & range & $\chi^{2}(2)$ & $p$ \\
\hline \multicolumn{9}{|l|}{ Updating (CMS) } \\
\hline Total & $10.0_{\mathrm{a}}$ & $8.00-15.0$ & 9.00 & $8.00-13.0$ & $7.00_{b}$ & $3.00-9.00$ & 12.7 & .002 \\
\hline Forward & $6.00_{\mathrm{a}}$ & $5.00-9.00$ & 5.50 & $5.00-8.00$ & $5.00_{\mathrm{b}}$ & $1.00-6.00$ & 7.50 & .024 \\
\hline \multicolumn{9}{|c|}{ Cognitive flexibility (NEPSY-II) } \\
\hline Number of correct sorts & 5.00 & $2.00-6.00$ & 5.00 & $3.00-7.00$ & 3.00 & $2.00-5.00$ & 3.81 & .149 \\
\hline Number of errors & 2.50 & $0.00-9.00$ & 3.00 & $1.00-13.0$ & 3.50 & $0.00-7.00$ & .664 & .717 \\
\hline
\end{tabular}

Note. Different subscripts indicate significant differences between groups based on Mann-Whitney U tests with Bonferroni correction $(p<.017)$. TD $=$ typically developing; DLD = developmental language disorder; DLD-S = group matched on spelling skills with TD children; DLD-AM = group matched on chronological age and phonological awareness skills with DLD-S; CMS = Children's Memory Scale, Digit Recall subtest (Cohen, 2001); NEPSY-II = Developmental Neuropsychological Assessment, Second Edition, Animal Sorting subtest (Korkman et al., 2012); TEA-Ch = Test of Everyday Attention for Children, Walk Don't Walk subtest (Manly et al., 1999). All subtests were French versions.

\subsection{Evolution of spelling performance}

To address our second research question and compare the three groups on their spelling performance, differences in the number of spelling errors made on the experimental dictation were analyzed using non-parametric tests. Median scores and group comparisons are displayed in Table 4 .

To examine the evolution of spelling performance in each group over the school year, a series of Friedman's ANOVAs were conducted. Results showed that TD children, $\chi^{2}(2)=19.6, p<.001$, the DLD-S group, $\chi^{2}(2)=9.75, p=.008$, and the DLD-AM group, $\chi^{2}(2)=6.75, \quad p=.034$, made significantly less spelling errors throughout the school year. To follow up these findings, Wilcoxon signed-rank tests with Bonferroni correction $(p<.017)$ were applied. Results revealed that the performance of the TD group improved significantly from T2 to T3, $Z=0.875, p=.001, r=.50$, and from $\mathrm{T} 1$ to $\mathrm{T} 3, \mathrm{Z}=-1.56, p<.001, r=.59$. No significant difference was noted from $\mathrm{T} 1$ to $\mathrm{T} 2, \mathrm{Z}=0.688, p=.052, r=.47$. The performance of the DLD-S group improved significantly from $\mathrm{T} 1$ to $\mathrm{T} 3, \mathrm{Z}=1.50, p=.003, r=.46$. No significant differences were found from $\mathrm{T} 1$ to $\mathrm{T} 2, \mathrm{Z}=0.375, p=.453$, $r=.10$, and from $\mathrm{T} 2$ to $\mathrm{T} 3, \mathrm{Z}=1.13, p=.024, r=.63$. In contrast, pairwise comparisons showed no significant difference for the DLD-AM group throughout the school year, from $\mathrm{T} 1$ to $\mathrm{T} 3, \mathrm{Z}=1.13, p=.024, r=.46$.
To compare the number of spelling errors between the three groups at each time of measurement, a series of KruskalWallis tests were used. Statistically significant differences between groups were observed at T1 and T3 (see Table 4). To follow up these results, Mann-Whitney $U$ tests with Bonferroni correction $(p<.017)$ were used. Results revealed that TD children produced significantly less spelling errors than the DLD-AM group at T1, $\mathrm{U}=-14.2, p<.001, r=.70$, and at T3, $\mathrm{U}=-11.2, p=.006, r=.53$. The DLD-S group produced a number of errors similar to that of TD children at T1, $\mathrm{U}=-1.47, p=.717, r=.08$, and at T3, $\mathrm{U}=-3.66, p=.368, r=.22$. The DLD-S group also produced significantly fewer errors than the DLD-AM group at T1, $\mathrm{U}=-12.7, p=.007, r=.68$. This significant difference was not maintained at $\mathrm{T} 3, \mathrm{U}=-7.56$, $p=.107, r=.47$. However, given the large effect size, a larger sample could show a significant difference between the two DLD groups.

In sum, these results showed that the TD and DLD-S groups produced a similar number of errors at each time of measurement during the school year, but TD children were those who progressed the most over the school year. In contrast, the DLD-AM group tended to produce significantly more spelling errors than the other two groups, and they made the least progress over the school year. 
Table 4. Median $(\mathrm{M} d n)$ and range of the number of spelling errors made on the experimental dictation for the three participant groups at the three times of measurement

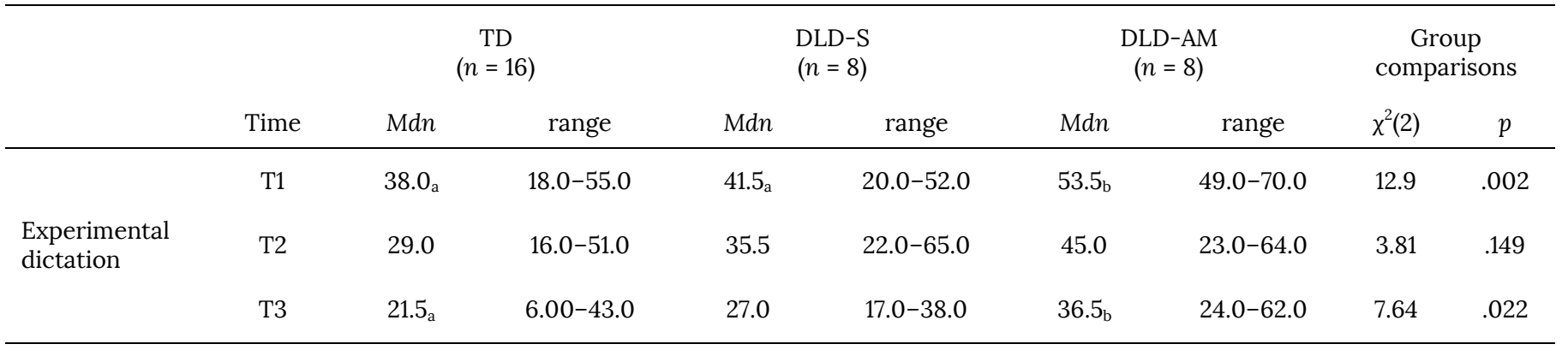

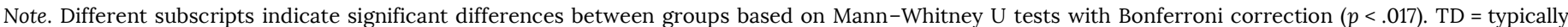

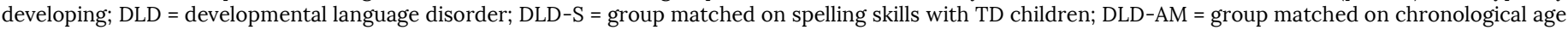
and phonological awareness skills with DLD-S; T1 = November; T2 = February; T3 = May (all in the same school year).

\subsection{Proportion of phonographic errors}

To address our third research question and compare the proportions of phonographic errors between the three groups, differences in the percentage of phonographic errors made on the experimental dictation were analyzed using non-parametric tests. Median percentages and group comparisons are displayed in Table 5.
First, to examine how the proportion of phonographic errors evolved in each group over the school year, a series of Friedman's ANOVAs were used. Results showed that the proportions of phonographic errors remained similar throughout the school year for TD children, $\chi^{2}(2)=3.88$, $p=.144$, for the DLD-S group, $\chi^{2}(2)=4.75, p=.093$, and for the DLD-AM group, $\chi^{2}(2)=4.75, p=.093$.

Table 5. Median (Mdn) and range of the percentage of phonographic errors among all spelling errors made on the experimental dictation for the three participant groups at the three times of measurement

\begin{tabular}{|c|c|c|c|c|c|c|c|c|c|}
\hline & \multirow[b]{2}{*}{ Time } & \multicolumn{2}{|c|}{$\begin{array}{c}\text { TD } \\
(n=16)\end{array}$} & \multicolumn{2}{|c|}{$\begin{array}{l}\text { DLD-S } \\
(n=8)\end{array}$} & \multicolumn{2}{|c|}{$\begin{array}{c}\text { DLD-AM } \\
(n=8)\end{array}$} & \multicolumn{2}{|c|}{$\begin{array}{c}\text { Group } \\
\text { comparisons }\end{array}$} \\
\hline & & $M d n$ & range & $\mathrm{M} d n$ & range & $\mathrm{Mdn}$ & range & $\chi 2(2)$ & $p$ \\
\hline \multirow{2}{*}{$\begin{array}{l}\text { Phonographic } \\
\text { errors }\end{array}$} & $\mathrm{T} 1$ & $29.9_{a}$ & $8.33-46.9$ & $34.9_{\mathrm{a}}$ & $20.0-40.0$ & $62.64_{b}$ & $57.1-75.7$ & 18.398 & $<.001$ \\
\hline & T3 & $33.2_{\mathrm{a}}$ & $0.00-51.2$ & 46.7 & $21.4-70.6$ & $50.24_{b}$ & $29.2-67.2$ & 6.884 & .032 \\
\hline
\end{tabular}

Note. Different subscripts indicate significant differences between groups based on Mann-Whitney U tests with Bonferroni correction $(p<.017)$. TD $=$ typically developing; DLD = developmental language disorder; DLD-S = group matched on spelling skills with TD children; DLD-AM = group matched on chronological age and phonological awareness skills with DLD-S; TC = combined data of T1, T2, T3; T1 = November; T2 = February; T3 = May (all in the same school year).

Second, as shown in Table 5, a series of Kruskal-Wallis tests showed that the proportions of phonographic errors were significantly different between groups at $\mathrm{T} 1, \mathrm{~T} 2$, and $\mathrm{T} 3$. Mann-Whitney U tests with Bonferroni correction $(p<.017)$ were used to follow up this finding. Results revealed that TD children produced significantly less phonographic errors than the DLD-AM group at the three times of measurement (T1, $U=-17.3, p<.001, r=.80 ; \mathrm{T} 2, \mathrm{U}=-14.9, p<.001, r=.76$; T3, $U=-9.81, p=.016, r=.51$ ). In contrast, over the school year, the TD and DLD-S groups tended to differ significantly (TC, $\mathrm{U}=-23.7, p=.001, r=.41$ ), more specifically at $\mathrm{T} 2$, $\mathrm{U}=-13.8, p=.001, r=.68$. However, no difference was noted at $\mathrm{T} 1, \mathrm{U}=-3.94, p=.332, r=.26$, and at $\mathrm{T} 3, \mathrm{U}=-7.19, p=.077$, $r=.34$. Finally, the proportions of phonographic errors between the two DLD groups only differed at T1, $\mathrm{U}=-13.4$, $p=.004, r=.84$, but not at T2, $\mathrm{U}=-1.13, p=.810, r=.03$, T3, $\mathrm{U}=-2.63, p=.576, r=.11$, or throughout the school year (TC, $\mathrm{U}=-18.5, p=.021, r=.36)$.

In sum, the TD and DLD-S groups produced fewer phonographic errors. In contrast, the DLD-AM group produced more phonographic errors. In fact, the spelling performance of the DLD-AM group was weaker than that of TD children throughout the school year. As for the two DLD 
groups, their performance was significantly different at $\mathrm{T} 1$ only. Even if the children in the DLD-S group had better spelling skills, their phonological representations still appeared to be fragile.

\subsection{Phonographic errors: A fine-grained analysis}

To address our fourth research question and compare the proportions of phoneme substitutions, omissions, and additions between the three groups, differences in the percentage of phonographic error types made on the experimental dictation were analyzed using non-parametric tests. Median percentages and group comparisons are displayed in Table 6.
To examine how the proportion of each type of phonographic error evolved in each group over the school year, a series of Friedman's ANOVA were used. Results showed that the percentages of phoneme substitutions of the TD group varied significantly over the year, $\chi^{2}(2)=8.40, p=.015$. Wilcoxon signed-rank tests with Bonferroni correction $(p<.017)$ showed that the percentages of substitutions increased significantly from $\mathrm{T} 1$ to $\mathrm{T} 2, \mathrm{Z}=-.938, p=.008, r=.29$, but not from $\mathrm{T} 1$ to $\mathrm{T} 3, \mathrm{Z}=-.188, p=.596, r=.15$, or from $\mathrm{T} 2$ to $\mathrm{T} 3$, $\mathrm{Z}=.750, p=.034, r=.32$. However, the percentages of phoneme substitutions remained similar for the DLD-S group, $\chi^{2}(2)=1.40, p=.497$ and for the DLD-AM group, $\chi^{2}(2)=.839, p=.657$.

Table 6. Median $(\mathrm{Mdn})$ and range of the percentage of phonographic error types among all phonographic errors made on the experimental dictation for the three participant groups at the three times of measurement

\begin{tabular}{|c|c|c|c|c|c|c|c|c|c|}
\hline \multirow{2}{*}{$\begin{array}{l}\text { Phonographic } \\
\text { error types }\end{array}$} & \multirow{2}{*}{ Time } & \multicolumn{2}{|c|}{$\begin{array}{c}\text { TD } \\
(n=16)\end{array}$} & \multicolumn{2}{|c|}{$\begin{array}{l}\text { DLD-S } \\
(n=8)\end{array}$} & \multicolumn{2}{|c|}{$\begin{array}{c}\text { DLD-AM } \\
(n=8)\end{array}$} & \multicolumn{2}{|c|}{$\begin{array}{c}\text { Group } \\
\text { comparisons }\end{array}$} \\
\hline & & $\mathrm{Mdn}$ & range & $\mathrm{Mdn}$ & range & $\mathrm{Mdn}$ & range & $\chi^{2}(2)$ & $p$ \\
\hline \multirow{4}{*}{ Substitutions } & $\mathrm{TC}$ & $78.2_{\mathrm{a}}$ & $0.00-100$ & $78.4_{a}$ & $41.7-92.9$ & $54.0_{\mathrm{b}}$ & $29.0-70.3$ & 31.5 & $<.001$ \\
\hline & $\mathrm{T} 1$ & $66.7_{\mathrm{a}}$ & $0.00-100$ & 69.5 & $41.7-85.7$ & $53.4_{\mathrm{b}}$ & $29.0-70.3$ & 6.62 & .037 \\
\hline & $\mathrm{T} 2$ & $89.4_{a}$ & $60.0-100$ & 68.6 & $45.5-92.9$ & $51.0_{\mathrm{b}}$ & $34.3-68.0$ & 14.4 & .001 \\
\hline & T3 & $78.4_{\mathrm{a}}$ & $0.00-100$ & $80.9 \mathrm{a}$ & $58.3-88.9$ & $54.0_{\mathrm{b}}$ & $46.2-66.7$ & 13.4 & .001 \\
\hline \multirow{4}{*}{ Omissions } & $\mathrm{TC}$ & $11.1_{a}$ & $0.00-46.7$ & $14.7 \mathrm{a}$ & $0.00-41.7$ & $36.7_{\mathrm{b}}$ & $16.7-58.1$ & 34.3 & $<.001$ \\
\hline & $\mathrm{T} 1$ & $13.6_{a}$ & $0.00-46.7$ & 23.0 & $0.00-41.7$ & $30.9_{b}$ & $24.3-58.1$ & 7.67 & .022 \\
\hline & $\mathrm{T} 2$ & $10.6_{a}$ & $0.00-40.0$ & 14.7 & $7.14-36.4$ & $36.0_{\mathrm{b}}$ & $16.7-53.6$ & 10.0 & .007 \\
\hline & T3 & $11.8_{\mathrm{a}}$ & $0.00-33.3$ & $11.4_{a}$ & $0.00-25.0$ & $42.5_{b}$ & $30.8-53.9$ & 16.4 & $<.001$ \\
\hline \multirow{4}{*}{ Additions } & $\mathrm{TC}$ & 0.00 & $0.00-100$ & 7.74 & $0.00-41.7$ & 5.20 & $0.00-26.1$ & 2.26 & .323 \\
\hline & $\mathrm{T} 1$ & 15.7 & $0.00-100$ & 8.57 & $0.00-41.7$ & 5.93 & $2.63-23.5$ & .124 & .940 \\
\hline & $\mathrm{T} 2$ & 0.00 & $0.00-17.7$ & 6.80 & $0.00-29.7$ & 4.20 & $0.00-26.1$ & 5.58 & .062 \\
\hline & T3 & 4.55 & $0.00-33.3$ & 9.89 & $0.00-16.7$ & 2.08 & $0.00-15.4$ & 1.50 & .471 \\
\hline
\end{tabular}

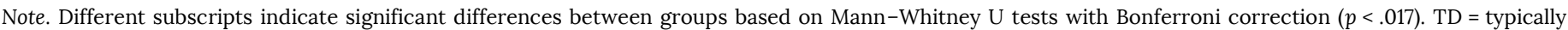

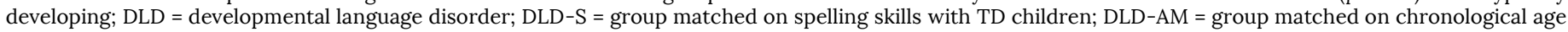
and phonological awareness skills with DLD-S; TC = combined data of T1, T2, T3; T1 = November; T2 = February; T3 = May (all in the same school year).

Regarding phoneme omissions, the percentages were relatively stable throughout the school year for TD children, $\chi^{2}(2)=1.09, \quad p=.581$, for the DLD-S group, $\chi^{2}(2)=.867$, $p=.648$, and for the DLD-AM group, $\chi^{2}(2)=1.23, p=.542$. Regarding phoneme additions, the percentages remained similar throughout the year for the DLD-S group, $\chi^{2}(2)=.207$, $p=.902$, and for the DLD-AM group, $\chi^{2}(2)=2.97, p=.227$. However, the percentages of phoneme additions of TD children varied significantly over the year, $\chi^{2}(2)=6.44$, $p=.040$, but Wilcoxon signed-rank tests with Bonferroni correction $(p<.017)$ did not reveal significant differences from $\mathrm{T} 1$ to $\mathrm{T} 2, \mathrm{Z}=.688, p=.052, r=.33$, from $\mathrm{T} 2$ to $\mathrm{T} 3$, $\mathrm{Z}=-.625, p=.077, r=.07$, and from $\mathrm{T} 1$ to $\mathrm{T} 3, \mathrm{Z}=.062$, $p=.860, r=.27$.

To compare the three groups on the proportion of phonographic error types at each time of measurement, a series of Kruskal-Wallis tests were used, and Mann-Whitney 
U tests with Bonferroni correction $(p<.017)$ were applied to follow up significant results. As shown in Table 6, for phoneme substitutions, significant differences between groups were observed at the three times of measurement. The DLD-S children (TC, $U=30.2, p<.0001, r=.6)$ and the TD children (TC, $\mathrm{U}=38.8, p<.0001, r=.63$ ) produced more phoneme substitutions over the school year in comparison with the DLD-AM children. No difference was noted between the DLD-S and the TD children (TC, $U=8.531, p=.220$, $r=.17)$. Specifically, the TD group produced, in a significantly greater proportion, more phoneme substitutions than the DLD-AM group at T1, $\mathrm{U}=9.84, p=.015, r=.48$, at $\mathrm{T} 2, \mathrm{U}=14.9$, $p<.001, r=.72$, and at T3, $U=13.8, p=.001, r=.67$. In contrast, the TD and DLD-S groups produced similar proportions of phoneme substitutions at T1, $\mathrm{U}=.031, p=.994$, $r=.019$, at $\mathrm{T} 2, \mathrm{U}=8.31, p=.040, r=.45$, and at $\mathrm{T} 3, \mathrm{U}=-.469$, $p=.908, r<.01$. The two DLD groups did not differ significantly at $\mathrm{T} 1, \mathrm{U}=9.81, p=.036, r=.55$, and at $\mathrm{T} 2$, $\mathrm{U}=6.63, p=.156, r=.42$. However, at $\mathrm{T} 1$, the large effect size indicated that the difference could be significant with a larger sample. At T3, the difference between these two groups was significant, $\mathrm{U}=14.3, p=.002, r=.80$.

For phoneme omissions, significant differences between groups were observed at the three times of measurement (see Table 6). The TD and the DLD-S groups produced similar proportions of phoneme omissions at T1, $\mathrm{U}=-3.06, p=.449$, $r=.18$, at $\mathrm{T} 2, \mathrm{U}=-3.00, p=.459, r=.21$, and at $\mathrm{T} 3, \mathrm{U}=-.219$, $p=.957, r=.03$. In contrast, the DLD-AM group produced, in a significantly greater proportion, more phoneme omissions than the TD group, at the three times of measurement (T1, $\mathrm{U}=-11.2, p=.006, r=.54 ; \mathrm{T} 2, \mathrm{U}=-12.8, p=.002, r=.58 ; \mathrm{T} 3$, $\mathrm{U}=-15.4, p<.001, r=.76)$. Over the school year, the two DLD groups differed in the proportion of phoneme omissions (TC, $\mathrm{U}=-33.7, p<.0001, r=.69)$. More specifically, at T3, a difference between these groups was observed, $U=-15.2$, $p=.001, r=0.84$, but no significant differences were noted at $\mathrm{T} 1, \mathrm{U}=-8.13, p=.082, r=.47$, and at $\mathrm{T} 2, \mathrm{U}=-9.75, p=.037$, $r=.64$. However, these large effect sizes indicated that differences could be significant with a larger sample.

Finally, for phoneme additions, no significant differences between groups were noted throughout the school year (see Table 6). In sum, the results showed that the DLD-AM group did more phonographic errors than the TD and DLD-S groups. In particular, the DLD-AM group did significantly more phoneme omissions all year long.

\section{Discussion}

The present study was conducted to investigate the EF and spelling performance of two groups of children with DLD in comparison with TD children: the DLD-S group, matched on the number of spelling errors produced with TD children, and the DLD-AM group, matched on chronological age and phonological awareness with the DLD-S group, but differing in the number of spelling errors produced. Results are discussed in relation to children's EF abilities, phonological awareness skills, and spelling profiles in the phonographic dimension.

\subsection{Executive functions in children with DLD}

Three EF components were assessed: inhibition, cognitive flexibility, and updating. Consistent with previous studies, all children with DLD performed similarly to TD children in the inhibition task (Finneran et al., 2009; Henry et al., 2011) and in the cognitive flexibility task (Dibbets et al., 2006; Henry et al., 2011; Im-Bolter et al., 2006). As a reminder, our inhibition and cognitive flexibility tasks did not involve expressive language. It is important to note that the TD group being approximately one year younger than the DLD groups, it probably highlighted some limits in these EF components in children with DLD. Comparing a TD group matched on chronological age with the DLD groups could be relevant to validate the presence of a delay in cognitive flexibility and inhibition. These results answered our first research question and supported our hypothesis, as no differences were found between groups for these two EF components. However, these components appeared to be fragile for the DLD groups.

As predicted, differences were observed only in the updating task. Many studies (Archibald \& Gathercole, 2006; Bishop, 2006; Montgomery et al., 2010) have demonstrated strong links between language impairments and working memory in children with DLD and hypothesized a deficit in this EF component. However, our results pointed out that it is not all children with DLD who present limitations in their updating capacity, as shown by Archibald and Joanisse (2009). Specifically, it was the children in the DLD-AM group who obtained the lowest scores on the updating task, whether it was on the forward subtask or on the backward one. Although their scores were significantly different only from TD children's scores, a significant difference could also appear between the two DLD groups given the medium and large effect sizes noted. Future studies including larger samples would be needed to confirm this hypothesis. In addition, as a reminder, it is important to note that the DLD-AM group had a lower score on the nonverbal intelligence task, even if it was within normal limits. This could explain the difference between the TD and DLD-AM groups in updating. Future studies should include a nonverbal intelligence matching procedure to better control this possible effect.

\subsection{Spelling performance and progress over the school year}

Even if children in the TD and DLD-S groups produced a similar number of spelling errors, our results showed that their error types could differ and that spelling profiles could be distinguished. Regarding our second research question, the three groups made progress and produced less spelling errors throughout the school year. However, TD children were those who progressed the most. These results supported our hypothesis and indicated that TD children's spelling skills would not remain similar to those of children in the DLD-S group throughout their academic years. Language impairments seem to hinder spelling development, and a 
delay was already noticeable in both DLD groups, particularly in the DLD-AM group.

We observed that the TD and DLD-S groups produced a similar number of spelling errors over the school year. It seems that the proportion of phonographic errors was also similar between these two groups at T1 (November) and T3 (May). At T2 (February), children in the DLD-S group produced more phonographic errors than TD children, and as many as their peers in the DLD-AM group. Therefore, to answer our third research question, results showed that qualitative variations could appear and differentiate the spelling profile of TD children from that of children with DLD-S.

Compared to TD children, children in the DLD-S group may have relied on other knowledge to spell so that they could achieve a quantitatively similar spelling performance. Children in the DLD-S group may have compensated their phonological difficulties by using a logographic procedure rather than an alphabetic procedure. Some children in the DLD-S group were older than TD children, and their greater exposure to written material could have contributed to their spelling performance. However, considering their weaker phonological awareness skills, their phonological representations remained unstable and inaccurate, as evidenced by their greater proportion of phonographic errors at $\mathrm{T} 2$.

\subsection{Phonological awareness skills and updating capacity in spelling performance}

Phonological awareness skills (Caravolas et al., 2001; Lervåg \& Hulme, 2010; Ouellette \& Sénéchal, 2008) and working memory (Lervåg \& Hulme, 2010; Stage \& Wagner, 1992) play a central role in spelling acquisition. Weak phonological awareness skills lead to phonographic errors (Bishop \& Clarkson, 2003). We observed this fact in both DLD groups, who tended to make more of these errors than their TD peers. We noted some differences in phonographic error type productions, and these differences did not seem to be only linked to phonological awareness skills.

First, phoneme substitution errors were produced in a larger proportion for each group compared to other error types. We observed that when the TD group produced substitutions, it was often due to the presence of a complex or contextual grapheme. For example, for the word girafe /ziraf/ (giraffe), a TD child who did not master the contextual grapheme $<\mathrm{g}>$, could have chosen another grapheme associated to this orthographic rule, thus also inadvertently affecting the phonology of the word, like in *guirafe /giraf/. This kind of substitution is more particularly associated to a lack of knowledge of the orthographic code rather than a symptom of weaker phonological awareness skills. In contrast, when the DLD groups produced phoneme substitutions, the children tended to choose phonemes close to the targeted ones (e.g., boulanger /bulanze/ - *poulancher /pulanfe/; argent /arzad/ - *azon /azon/). Their phoneme substitutions reflected a weaker phoneme manipulation.
Second, different spelling profiles emerged from the phoneme omission error proportions. Children in the DLDAM group were those who produced the largest proportion of phoneme omissions, all year long. In contrast, the other groups produced, anecdotally, some phoneme omissions at each time of measurement. It is interesting to note that the TD and DLD-S groups had similar updating capacities. We can hypothesize that children in the DLD-S group were more able to manipulate and update information in working memory than their peers in the DLD-AM group. Children in the DLD-S group seemed to be able, like their TD peers, to keep track of the coupling of phonemes to graphemes, without omitting phonemes, as evidenced by their smaller proportion of omissions. Their phoneme substitutions may hint at confusions with similar-sounding phonemes, rather than a weak phonological information manipulation in working memory. Therefore, it seems that their updating capacity supported their spelling, and their phonographic productions as predicted by previous studies (Bishop \& Clarkson, 2003; Brizzolara et al., 2011; Larkin \& Snowling, 2008).

On the other hand, considering that both DLD groups had similar phonological skills, it is difficult to argue that the greater proportion of phonographic errors made by children in the DLD-AM group (and, more precisely, their greater production of phoneme omissions) were due to their phonological impairments. In fact, it appears that children in the DLD-AM group presented limited updating capacity, as shown by their scores on the digit recall task. It is possible that their poorer updating capacity restrained their ability to maintain and segment a phonological sequence in working memory, and to associate each phoneme with the correct grapheme in the right order. Therefore, manipulating information in working memory seems to be more difficult for certain children with DLD, and this difficulty is likely to have led to the greater proportion of phoneme omissions observed in their spelling.

In addition, limited updating capacities could also lead to specific phoneme addition errors. Even if there were no difference in phoneme addition productions between the groups, these additions differed qualitatively. On the one hand, phoneme additions produced by the TD and DLD-S groups showed that they focus on the orthographic code and oversegment the phoneme structure (e.g., sortir /sortir/ *soretir /soratir/; partir /partir/- *paretir /paratir/). On the other hand, the DLD-AM group seemed to be overwhelmed by the phoneme-grapheme storage and processing, which led to illogical phoneme addition errors (e.g., beau, /bo/ - *bor, /bor/; cour /kur/ - *croure /krur/). Consequently, the DLD-AM phoneme additions and, more particularly, phoneme omissions highlight limited updating capacities which restrain the ability to maintain phoneme sequences in working memory, and to convert each phoneme into the right grapheme.

Children with DLD are generally able to manipulate phonological units in isolated and decontextualized tasks 
(Zourou et al., 2010). However, when they have to properly use and transfer these abilities in a complex and authentic task, like spelling words, they are experiencing difficulties. Spelling is not only a matter of maintaining a phonological sequence in working memory; it also implies a phoneme segmentation and a conversion of each correct phoneme into the correct grapheme stored in long-term memory. In the context of an isolated-word dictation-where cognitive resources are not required by processing syntactic structures, grammar, or the organization of ideas, as they would be in written text production-it appears that children in the DLD-AM group were already overwhelmed by the spelling task. Spelling represents a heavy processing task (Lervåg \& Hulme, 2010), even in a decontextualized form, because it draws on many cognitive and linguistic abilities simultaneously. Regarding spelling acquisition, our results help to clarify the updating capacity in children with DLD by suggesting that impairments in this EF component may have led to different spelling profiles and particular error patterns, such as a greater proportion of phoneme omissions. These results answered our fourth research question. Language impairments affect and delay the spelling development of children with DLD, and the presence of an updating deficit may exacerbate this delay. Future studies with larger samples would be needed to confirm this hypothesis and, as explained previously, a better control of nonverbal intelligence could be recommended.

Only a handful of studies have examined updating capacity in relation to spelling skills, and most of them targeted the TD children population (e.g., Caravolas et al., 2001; Lervåg \& Hulme, 2010). To our knowledge, the present study appears to be one of the first to distinguish spelling profiles in the DLD population, in relation to updating capacity. Our results suggest that weaker phonological awareness skills lead to a greater propensity for phonographic errors, and that weaker updating capacity does not allow for maintaining, manipulating, and correctly converting all phonemes into graphemes without omitting certain phonemes in spelling. Updating capacity could discriminate skilled from less skilled spellers, as shown by the examination of children's written productions (Roebers \& Jäger, 2014). In addition, through a longitudinal design, this study contributes to a better understanding of the delay in spelling acquisition of children with DLD. More longitudinal studies spanning longer periods are needed to clarify the nature of this delay.

\section{Conclusion}

The present study examined the EF and spelling performance of two groups of children with DLD in comparison with TD children. Our research showed that the three groups had similar EF abilities, except for the DLD-AM group which was weaker on the updating task. These difficulties probably led to the weaker spelling performance of children in the DLDAM group. These results help to clarify the updating capacity in children with DLD, and they suggest that impairments in this EF component possibly lead to different spelling profiles.

\subsection{Limitations}

There are two main limitations to the present study. First, larger samples would increase statistical power and allow for parametric analyses as well as correlation and regression analyses. Of note, the large and medium effect sizes reported here pointed to possible distinctions between the two DLD groups, and larger samples could lead to significant differences. Second, to measure updating, we used only a digit recall task, and that is not enough to get a global picture of children's updating capacities. Including additional updating tasks, such as verbal and nonverbal measures, could be relevant in future studies.

\subsection{Theoretical and clinical implications}

Our findings are in line with the view that children with DLD present a delay in spelling acquisition (Cordewener et al., 2012; Nauclér, 2004; Snowling et al., 2000). We highlight the possibility of an exacerbated delay linked to a deficit in updating capacity. Additional research is required to more fully understand how oral language and updating abilities influence spelling and its learning.

The overarching goal of the present study was to enhance our understanding of spelling performance. Our results indicate that children who exhibit language impairments and limitations in updating capacity tend to omit phonemes more frequently when spelling words, and that their phonological representations seem to be more fragile. Interventions should focus on the development of phonological awareness, but also on revision and rereading spelled words as strategies. In addition, it could be pertinent to guide children toward larger phonological units, such as morphemes, to develop their morphological awareness and enhance their spelling skills. Finally, future studies testing interventions that combine learning to spell and enhancing updating capacities could be relevant.

\section{References}

Altemeier, L. E., Abbott, R. D., \& Berninger, V. W. (2008). Executive functions for reading and writing in typical literacy development and dyslexia. Journal of Clinical and Experimental Neuropsychology, 30(5), 588-606. https://doi.org/10.1080/13803390701562818

Altemeier, L. E., Jones, J., Abbott, R. D., \& Berninger, V. W. (2006). Executive functions in becoming writing readers and reading writers: Note taking and report writing in third and fifth graders. Developmental Neuropsychology, 29(1), 161-173. https://doi.org/10.1207/s15326942dn2901_8

Apel, K., \& Masterson, J. J. (2001). Theory-guided spelling assessment and intervention: A case study. Language, Speech \& Hearing Services in Schools, 32(3), 182-195. https://doi.org/10.1044/0161-1461(2001/017) 
Archibald, L. M. D., \& Gathercole, S. E. (2007). The complexities of complex memory span: Storage and processing deficits in specific language impairment. Journal of Memory and Language, 57(2), 177-194. https://doi.org/10.1016/j.jml.2006.11.004

Archibald, L. M. D., \& Gathercole, S. E. (2006). Short-term and working memory in specific language impairment. International Journal of Language $\mathcal{E}$ Communication Disorders, 41(6), 675-693. https://doi.org/10.1080/13682820500442602

Archibald, L. M. D., \& Joanisse, M. F. (2009). On the sensitivity and specificity of nonword repetition and sentence recall to language and memory impairments in children. Journal of Speech, Language, and Hearing Research, 52(4), 899-914. https://doi.org/10.1044/1092-4388(2009/08-0099)

Archibald, L. M. D., Joanisse, M., \& Edmunds, A. (2011). Specific language or working memory impairments: A small scale observational study. Child Language Teaching \& Therapy, 27(3), 294-312. https://doi.org/10.1177/0265659010396779

Åsberg Johnels, J., Kopp, S., \& Gillberg, C. (2012). Spelling difficulties in school-aged girls with attentiondeficit/hyperactivity disorder. Journal of Learning Disabilities, 47(5), 424-434. https://doi.org/10.1177/0022219412467058

Berninger, V. W., Garcia, N. P., \& Abbott, R. D. (2009). Multiple processes that matter in writing instruction and assessment. In G. A. Troia (Ed.), Instruction and assessment for struggling writers: Evidence-based practices (pp. 15-50). New York, NY: Guilford Press.

Best, J. R., Miller, P. H., \& Jones, L. L. (2009). Executive functions after age 5: Changes and correlates. Developmental Review, 29(3), 180-200. https://doi.org/10.1016/j.dr.2009.05.002

Bishop, D. V. M. (2006). What causes specific language impairment in children? Current Directions in Psychological Science, 15(5), 217-221. https://doi.org/10.1111/j.1467-8721.2006.00439.x

Bishop, D. V. M., \& Adams, C. (1990). A prospective study of the relationship between specific language impairment, phonological disorders and reading retardation. Journal of Child Psychology and Psychiatry, 31(7), 1027-1050. https://doi.org/10.1111/j.1469-7610.1990.tb00844.x

Bishop, D. V. M., \& Clarkson, B. (2003). Written language as a window into residual language deficits: A study of children with persistent and residual speech and language impairments. Cortex, 39(2), 215-237. https://doi.org/10.1016/s0010-9452(08)70106-0
Bishop, D. V. M., \& Norbury, C. F. (2005). Executive functions in children with communication impairments, in relation to autistic symptomatology: II: Response inhibition. Autism, 9(1), 29-43. https://doi.org/10.1177/1362361305049028

Bishop, D. V. M., Snowling, M. J., Thompson, P. A., Greenhalgh, T. and the CATALISE-2 consortium. (2017). Phase 2 of CATALISE: A multinational and multidisciplinary Delphi consensus study of problems with language development: Terminology. Journal of Child Psychology and Psychiatry, 58(10), 1068-1080. https://doi.org/10.1111/jcpp.12721

Bishop, D. V. M., Snowling, M. J., Thompson, P. A., Greenhalgh, T. and CATALISE consortium (2016). CATALISE: A multinational and multidisciplinary Delphi Consensus study. Identifying language impairments in children. PLOS ONE, 11(7), e0158753. https://doi.org/10.1371/journal.pone.0158753

Botting, N., \& Conti-Ramsden, G. (2001). Non-word repetition and language development in children with specific language impairment (SLI). International Journal of Language E Communication Disorders, 36(4), 421-432. https://doi.org/10.1080/13682820110074971

Brizzolara, D., Gasperini, F., Pfanner, L., Cristofani, P., Casalini, C., \& Chilosi, A. M. (2011). Long-term reading and spelling outcome in Italian adolescents with a history of specific language impairment. Cortex, 47(8), 955-973. https://doi.org/10.1016/j.cortex.2011.02.009

Broc, L., Bernicot, J., Olive, T., Favart, M., Reilly, J., Quémart, P., \& Uzé, J. (2013). Lexical spelling in children and adolescents with specific language impairment: Variations with the writing situation. Research in Developmental Disabilities, 34(10), 3253-3266. https://doi.org/10.1016/j.ridd.2013.06.025

Brown, L., Sherbenou, R. J., \& Johnsen, S. K. (1997). Test of nonverbal intelligence (TONI-3). ( $3^{\text {rd }}$ ed.). Austin, TX: ProEd.

Caravolas, M., Hulme, C., \& Snowling, M. J. (2001). The foundations of spelling ability: Evidence from a 3-year longitudinal study. Journal of Memory and Language, 45(4), 751-774. https://doi.org/10.1006/jmla.2000.2785

Cohen, M. J. (2001). Échelle clinique de mémoire pour enfants (CMS). Toronto, ON: Pearson.

Cordewener, K. A. H., Bosman, A. M. T., \& Verhoeven, L. (2012). Specific language impairment affects the early spelling process quantitatively but not qualitatively. Research in Developmental Disabilities, 33(4), 1041-1047. https://doi.org/10.1016/j.ridd.2012.01.011 
Diamond, A. (2013). Executive functions. Annual Review of Psychology, 64(1), 135-168.

https://doi.org/10.1146/annurev-psych-113011-143750

Dibbets, P., Bakker, K., \& Jolles, J. (2006). Functional MRI of task switching in children with specific language impairment (SLI). Neurocase, 12(1), 71-79. https://doi.org/10.1080/13554790500507032

Drijbooms, E., Groen, M. A., \& Verhoeven, L. (2015). The contribution of executive functions to narrative writing in fourth grade children. Reading and Writing, 28(7), 9891011. https://doi.org/10.1007/s11145-015-9558-z

Ebert, K. D., \& Kohnert, K. (2011). Sustained attention in children with primary language impairment: A metaanalysis. Journal of Speech, Language, and Hearing Research, 54(5), 1372-1384. https://doi.org/10.1044/1092-4388(2011/10-0231)

Fayol, M. (2008). Les erreurs : manière d'appréhender la production orthographique. In M. Fayol, \& J.-P. Jaffré (Eds.), Orthographier (pp. 123-136). Paris, France: Presses universitaires de France.

Finneran, D. A., Francis, A. L., \& Leonard, L. B. (2009). Sustained attention in children with specific language impairment (SLI). Journal of Speech, Language, and Hearing Research, 52(4), 915-929. https://doi.org/10.1044/1092-4388(2009/07-0053)

Graf Estes, K., Evans, J. L., \& Else-Quest, N. M. (2007). Differences in the nonword repetition performance of children with and without specific language impairment: A meta-analysis. Journal of Speech, Language, and Hearing Research, 50(1), 177-195. https://doi.org/10.1044/1092-4388(2007/015)

Hanson, R. A., \& Montgomery, J. W. (2002). Effects of general processing capacity and sustained selective attention on temporal processing performance of children with specific language impairment. Applied Psycholinguistics, 23(1), 75-93. https://doi.org/10.1017/s0142716402000048

Henry, L. A., Messer, D. J., \& Nash, G. (2011). Executive functioning in children with specific language impairment. Journal of Child Psychology and Psychiatry, 53(1), 37-45. https://doi.org/10.1111/j.1469-7610.2011.02430.x

Hooper, S. R., Costa, L. J., McBee, M., Anderson, K. L., Yerby, D. C., Knuth, S. B., \& Childress, A. (2010). Concurrent and longitudinal neuropsychological contributors to written language expression in first and second grade students. Reading and Writing, 24(2), 221-252. https://doi.org/10.1007/s11145-010-9263-x

Hooper, S. R., Swartz, C. W., Wakely, M. B., de Kruif, R. E. L., \& Montgomery, J. W. (2002). Executive functions in elementary school children with and without problems in written expression. Journal of Learning Disabilities, 35(1), 57-68. https://doi.org/10.1177/002221940203500105
Im-Bolter, N., Johnson, J., \& Pascual-Leone, J. (2006). Processing limitations in children with specific language impairment: The role of executive function. Child Development, 77(6), 1822-1841. https://doi.org/10.1111/j.1467-8624.2006.00976.x

Jaffré, J.-P., \& Fayol, M. (2006). Orthography and literacy in French. In R. M. Joshi, \& P. G. Aaron (Eds.), Handbook of Orthography and Literacy (pp. 81-104). New Jersey: Lawrence Erlbaum Associates.

Jurado, M. B., \& Rosselli, M. (2007). The elusive nature of executive functions: A review of our current understanding. Neuropsychology Review, 17(3), 213-233. https://doi.org/10.1007/s11065-007-9040-z

Kellogg, R. T., Whiteford, A. P., Turner, C. E., Cahill, M., \& Mertens, A. (2013). Working memory in written composition: A progress report. Journal of Writing Research, 5(2), 159-190. https://doi.org/10.17239/jowr2013.05.02.1

Korkman, M., Kirk, U., \& Kemp, S. (2012). Bilan neuropsychologique de l'enfant (NEPSY-II) (2 ${ }^{\text {nd }}$ ed.). Toronto, ON: Pearson.

Larkin, R. F., \& Snowling, M. J. (2008). Comparing phonological skills and spelling abilities in children with reading and language impairments. International Journal of Language E Communication Disorders, 43(1), 111-124. https://doi.org/10.1080/13682820601178584

Larkin, R. F., Williams, G. J., \& Blaggan, S. (2013). Delay or deficit? Spelling processes in children with specific language impairment. Journal of Communication Disorders, 46(5-6), 401-412. https://doi.org/10.1016/j.jcomdis.2013.07.003

Leonard, L. B. (2014). Children with specific language impairment ( $2^{\text {nd }}$ ed.). Cambridge, MA: The MIT Press.

Lervåg, A., \& Hulme, C. (2010). Predicting the growth of early spelling skills: Are there heterogeneous developmental trajectories? Scientific Studies of Reading, 14(6), 485-513. https://doi.org/10.1080/10888431003623488

Lété, B., Sprenger-Charolles, L., \& Colé, P. (2004). MANULEX: A grade-level lexical database from French elementary school readers. Behavior Research Methods, Instruments, E Computers, 36(1), 156-166. https://doi.org/10.3758/bf03195560

Lukács, Á., Ladányi, E., Fazekas, K., \& Kemény, F. (2016). Executive functions and the contribution of short-term memory span in children with specific language impairment. Neuropsychology, 30(3), 296-303. https://doi.org/10.1037/neu0000232

Mackie, C. J., \& Dockrell, J. E. (2004). The nature of written language deficits in children with SLI. Journal of Speech, Language, and Hearing Research, 47(6), 1469-1483. https://doi.org/10.1044/1092-4388(2004/109) 
Mackie, C. J., Dockrell, J., \& Lindsay, G. (2012). An evaluation of the written texts of children with SLI: the contributions of oral language, reading and phonological short-term memory. Reading and Writing, 26(6), 865888. https://doi.org/10.1007/s11145-012-9396-1

Manly, T., Robertson, I. H., Anderson, V., \& Nimmo-Smith, I. (1999). TEA-Ch: Test d'évaluation de l'attention chez l'enfant. Toronto, ON : Pearson.

Marton, K. (2008). Visuo-spatial processing and executive functions in children with specific language impairment. International Journal of Language $\mathcal{E}$ Communication Disorders, 43(2), 181-200. https://doi.org/10.1080/16066350701340719

Marton, K., Campanelli, L., Scheuer, J., Yoon, J., \& Eichorn, N. (2012). Executive function profiles in children with and without specific language impairment. Journal of Applied Psycholinguistics, 12(3), 57-73. PMID: 25302062

Masterson, J. J., \& Apel, K. (2010). The spelling sensitivity score: Noting developmental changes in spelling knowledge. Assessment for Effective Intervention, 36(1), 35-45. https://doi.org/10.1177/1534508410380039

Masterson, J. J., \& Apel, K. (2000). Spelling assessment: Charting a path to optimal intervention. Topics in Language Disorders, 20(3), 50-65.

https://doi.org/10.1097/00011363-200020030-00007

Ministère de l'Éducation, du Loisir et du Sport (2008). Déclaration des effectifs scolaires, 2005-2006 et 20062007. Québec: Gouvernement du Québec.

Miyake, A., \& Friedman, N. P. (2012). The nature and organization of individual differences in executive functions: Four general conclusions. Current Directions in Psychological Science, 21(1), 8-14.

https://doi.org/10.1177/0963721411429458

Miyake, A., Friedman, N. P., Emerson, M. J., Witzki, A. H., Howerter, A., \& Wager, T. D. (2000). The unity and diversity of executive functions and their contributions to complex "frontal lobe" tasks: A latent variable analysis. Cognitive Psychology, 41(1), 49-100.

https://doi.org/10.1006/cogp.1999.0734

Montgomery, J. W. (2002). Understanding the language difficulties of children with specific language impairments: Does verbal working memory matter? American Journal of Speech-Language Pathology, 11(1), 7791. https://doi.org/10.1044/1058-0360(2002/009)

Montgomery, J. W., Magimairaj, B. M., \& Finney, M. C. (2010). Working memory and specific language impairment: An update on the relation and perspectives on assessment and treatment. American Journal of Speech-Language Pathology, 19(1), 78-94. https://doi.org/10.1044/10580360(2009/09-0028)
Nash, H. M., Hulme, C., Gooch, D., \& Snowling, M. J. (2013). Preschool language profiles of children at family risk of dyslexia: Continuities with specific language impairment. Journal of Child Psychology and Psychiatry, 54(9), 958968. https://doi.org/10.1111/jcpp.12091

Nauclér, K. (2004). Spelling development in Swedish children with and without language impairment. Journal of Multilingual Communication Disorders, 2(3), 207-215. https://doi.org/10.1080/14769670400018315

Noterdaeme, M., Amorosa, H., Mildenberger, K., Sitter, S., \& Minow, F. (2001). Evaluation of attention problems in children with autism and children with a specific language disorder. European Child \& Adolescent Psychiatry, 10(1), 58-66. https://doi.org/10.1007/s007870170048

Ouellette, G. P., \& Sénéchal, M. (2008). A window into early literacy: Exploring the cognitive and linguistic underpinnings of invented spelling. Scientific Studies of Reading, 12(2), 195-219. https://doi.org/10.1080/10888430801917324

Pauls, L. J., \& Archibald, L. M. D. (2016). Executive functions in children with specific language impairment: A metaanalysis. Journal of Speech, Language, and Hearing Research, 59(5), 1074-1086. https://doi.org/10.1044/2016_jslhr-1-15-0174

Perfetti, C. A. (1997). Psycholinguistique de l'orthographe et de la lecture. In L. Rieben, M. Fayol, \& C. A. Perfetti (Eds.), Des orthographes et leur acquisition (pp. 37-56). Lausanne/Paris: Delachaux et Niestlé.

Pothier, B., \& Pothier, P. (2004). Échelle d'acquisition en orthographe lexicale. Paris, France: Retz.

Préfontaine, R.-T., \& Préfontaine, G. (1968). Vocabulaire oral des enfants de 5 à 8 ans au Canada français: Méthodologie de l'enseignement de l'orthographe par la méthode "Le Sablier". Montreal, QC: Librairie Beauchemin.

Ribaupierre, A. D. (2002). Working memory and attentional processes across the lifespan. In P. Graf \& N. Ohta (Eds.), Lifespan development of human memory (pp. 59-80). Cambridge: MIT Press.

Roebers, C. M., \& Jäger, K. (2014). The relative importance of fine motor skills, intelligence, and executive functions for first graders' reading and spelling skills. Perspectives on Language and Literacy, 40(2), 13-17.

Röthlisberger, M., Neuenschwander, R., Cimeli, P., \& Roebers, C. M. (2013). Executive functions in 5- to 8-year olds: Developmental changes and relationship to academic achievement. Journal of Educational and Developmental Psychology, 3(2), 153-167. https://doi.org/10.5539/jedp.v3n2p153 
Silliman, E. R., Bahr, R. H., \& Peters, M. L. (2006). Spelling patterns in preadolescents with atypical language skills: Phonological, morphological, and orthographic factors. Developmental Neuropsychology, 29(1), 93-123. https://doi.org/10.1207/s15326942dn2901_6

Spaulding, T. J. (2010). Investigating mechanisms of suppression in preschool children with specific language impairment. Journal of Speech, Language, and Hearing Research, 53(3), 725-738. https://doi.org/10.1044/10924388(2009/09-0041)

Snowling, M., Bishop, D. V. M., \& Stothard, S. E. (2000). Is preschool language impairment a risk factor for dyslexia in adolescence? Journal of Child Psychology and Psychiatry, 41(5), 587-600. https://doi.org/10.1017/s0021963099005752

Stage, S. A., \& Wagner, R. K. (1992). Development of young children's phonological and orthographic knowledge as revealed by their spellings. Developmental Psychology, 28(2), 287-296. https://doi.org/10.1037//0012-1649.28.2.287

Vugs, B., Cuperus, J., Hendriks, M., \& Verhoeven, L. (2013). Visuospatial working memory in specific language impairment: A meta-analysis. Research in Developmental Disabilities, 34(9), 2586-2597.

https://doi.org/10.1016/j.ridd.2013.05.014
Walda, S. A. E., van Weerdenburg, M., Wijnants, M. L., \& Bosman, A. M. T. (2014). Progress in reading and spelling of dyslexic children is not affected by executive functioning. Research in Developmental Disabilities, 35(12), 3431-3454. https://doi.org/10.1016/j.ridd.2014.08.013

Weyandt, L. L., \& Willis, W. G. (1994). Executive functions in school-aged children: Potential efficacy of tasks in discriminating clinical groups. Developmental Neuropsychology, 10(1), 27-38. https://doi.org/10.1080/87565649409540564

Wiig, E. H., Secord, W. A., Semel, E., Boulianne, L., \& Labelle, M. (2009). Évaluation clinique des notions langagières fondamentales - version pour francophones du Canada (CELF-CDN-F). Toronto, ON : Pearson.

Zourou, F., Ecalle, J., Magnan, A., \& Sanchez, M. (2010). The fragile nature of phonological awareness in children with specific language impairment: Evidence from literacy development. Child Language Teaching and Therapy, 26(3), 347-358. https://doi.org/10.1177/0265659010369288 


\title{
THEORETICAL REVIEW
}

\section{The role of executive function in the construction and employment of scientific and mathematical concepts that require conceptual change learning}

\author{
Stella Vosniadou ${ }^{1,2^{\star}}$, Dimitrios Pnevmatikos ${ }^{3}$, Nikos Makris $^{4}$
}

\begin{abstract}
We discuss the theoretical rationale and behavioral evidence for the involvement of Executive Function (EF) skills in the construction and employment of scientific and mathematical concepts that require conceptual changes for their formation. It is argued that conceptual changes such as knowledge revision and the formation of new and counter-intuitive concepts require extensive attention, increased comprehension monitoring, adoption of multiple perspectives, comparison of new information with prior knowledge and inhibition of prior knowledge and thus are very likely to recruit the EF skills of working memory, shifting and inhibition. The results of empirical research have shown that EF skills are indeed recruited in the construction and employment of such tasks. Particular emphasis has been paid to the role of inhibition which seems to be specifically recruited in tasks in which the use of a scientific or mathematical concept contradicts an initial concept which must be rejected. Further research is needed with an emphasis on training studies to investigate the effects on student learning of different kinds of interventions that integrate EF training with the teaching of science and mathematics.
\end{abstract}

\footnotetext{
${ }^{1}$ National \& Kapodistrian University of Athens, Department of Philosophy and History of Science, Athens, Greece

${ }^{2}$ The Flinders University of South Australia, School of Education, Adelaide, Australia

${ }^{3}$ University of Western Macedonia, Florina, Greece

${ }^{4}$ Democritus University of Thrace, Nea Chili, Alexandroupolis, Greece

* Author email address: stella.vosniadou@flinders.edu.au
}

To cite this article: Vosniadou, S., Pnevmatikos, D., \& Makris, N. (2018). The role of executive function in the construction and employment of scientific and mathematical concepts that require conceptual change learning. Neuroeducation, 5(2), 62-72.

DOI: https://doi.org/10.24046/neuroed.20180502.62

Received on November $22^{\text {nd }}$, 2017. Received in revised form on April $28^{\text {th }}, 2018$.

Accepted on May 10 ${ }^{\text {th }}, 2018$. Available online on September $19^{\text {th }}, 2018$.

Neuroeducation, 5(2), 62-72

ISSN: 1929-1833

All rights reserved (C) 2018 - Association for Research in Neuroeducation 


\section{Introduction}

The complex knowledge involved in the construction and employment of science and mathematics concepts is represented in distributed networks located in different parts of the adult brain, making executive control indispensable for deciding what to access and what to suppress (Allan et al., 2014; Jacob \& Parkinson, 2015). Executive function (EF) skills such as working memory, task switching or shifting, and inhibitory control are fundamental for engaging in the goaldirected control of thought and behavior, for managing existing knowledge networks, and for the inhibition of learned responses in order to acquire the new and counterintuitive concepts of currently accepted science and mathematics.

Functional magnetic resonance imaging studies have established a link between EF skills and well-defined areas of the prefrontal cortex (PFC) and specifically the dorsal lateral prefrontal cortex (DLPFC) and the anterior cingulate cortex (ACC) (Fuster, 2015). Developmental studies indicate that even infants can use aspects of the frontal system to suppress inappropriate responses in order to support task appropriate behavior (Bell \& Fox, 1992). Nevertheless, there is a protracted development of these regions which has been interpreted to support the creation of increasingly more abstract goal representations. These abstract goal representations enable children and adolescents to improve their cognitive control both in reaction to environmental signals and in pro-active preparation for such control (Munakata, Snyder, \& Chatham, 2012).

EF skills have been found to be significantly related to academic achievement even when intelligence and prior knowledge are controlled for (for meta-analyses, see Allan et al., 2014; Jacob \& Parkinson, 2015), including performance in reading, (Kieffer, Vukovic, \& Berry, 2013; van de Sluis, De long, \& Van Der Leij, 2007); in math (Blair \& Razza, 2007; Bull, Epsy, \& Wiebe, 2008; Siegler \& Pyke, 2013; Vukovic et al., 2014); and in science (Mayer et al., 2014). This is not a surprising result in view of the importance of persistent attention, working memory and cognitive flexibility for success in classroom learning (Lyons \& Zelazo, 2011; Zelazo, Blair, \& Willoughby, 2017).

In this article, we focus specifically on a subset of academic tasks that use science and mathematics concepts which required conceptual changes for their construction. In the pages that follow we will define what we mean by conceptual changes in science and mathematics and describe the theoretical rationale and behavioral evidence for the involvement of EF skills in their construction and employment.

\section{Conceptual changes in the learning of science and mathematics}

Conceptual change research investigates the kind of learning that requires considerable changes in existing knowledge and the formation of new concepts, new representations, and new ontological categories. A great deal of learning can be accomplished by incorporating new information to existing conceptual structures. However, sometimes the acquisition of new information cannot be simply added on what is already known; in fact, it might come in direct conflict with what is already known. In these cases, learning requires the revision of prior knowledge. Often the Piagetian terms 'assimilation' and 'accommodation' have been used to refer to the distinction between adding new information to existing knowledge structures as opposed to altering or revising existing knowledge structures (Piaget, 1985). Conceptual change research has been instrumental in describing the different kinds of knowledge revision that take place with development and learning, such as the differentiation of concepts, (e.g., the differentiation of the concept of heat from temperature, Wiser \& Carey, 1983), the re-assignment of a concept to a new ontological category (e.g., the reassignment of the concept of force from the category of substances to the category of interactions, Chi, 2013); and of the creation of new concepts, new categories or new representations. For example, the construction of even the simple concept of the spherical earth and the explanation of the day/night cycle require considerable conceptual changes over young children's initial geocentric representation of the Earth as a flat physical object with a moving Sun and Moon located in the sky above and hiding behind mountains or clouds (Vosniadou \& Brewer, 1992, 1994). These conceptual changes require, amongst others, the creation of new counter-intuitive representations of the Earth, the Sun and the Moon, in a heliocentric solar system and the recategorization of the Earth in the category of astronomical as opposed to non-astronomical objects (Vosniadou, 2013; Vosniadou \& Skopeliti, 2013).

The construction of scientific and mathematical concepts often requires conceptual changes in prior knowledge because children form initial understandings of the physical and social world on the basis of their observations and lay culture before they are exposed to scientific and mathematical concepts. These experientially based, initial constructions are usually very different from the currently culturally accepted scientific and mathematical concepts, which can be rather counter-intuitive. Let us not forget that it took hundredths of years of research and several scientific revolutions to establish many of the scientific concepts which students are taught in schools today. As a result, the learning of science and mathematics can be quite taxing for students who must undertake considerable conceptual changes in their initial conceptual structures in order to achieve it (Carey, 1985; Chi, 2013; Vosniadou, 2013).

For a long time, conceptual change researchers implicitly assumed that when scientific explanations and theories are acquired, they replace initial understandings. Although some researchers had suggested that this may not be the case some time ago (e.g., Caravita \& Halldén, 1994; Inagaki \& Hatano, 2004), it is only recently that a body of evidence started to be accumulated demonstrating the co-existence of initial 
understandings and scientific explanations in a number of different knowledge domains (physics, biology, medicine, psychology, mathematics), different cultures (American, European, African, indigenous populations), and using different methodologies (interviews, questionnaires, reaction time studies, neuroimaging).

The bulk of this evidence comes from a series of psychological studies which investigate the employment of science concepts after they have been constructed. These studies have shown that both children and adults, across many different cultures, frequently use, amongst others, both natural and supernatural explanations of phenomena such as creationist vs. evolutionary accounts of the origin of species (Evans \& Lane, 2011), biological vs. supernatural explanations for the transmission and cure of serious illnesses (Legare \& Gelman, 2008, 2009), supernatural vs. scientific accounts of death (Legare et al., 2012), and dualistic vs. materialistic explanations for the mind (Preston, Ritter, \& Hepler, 2013).

Further evidence comes from reaction time studies which show that both children and adults are slower (and sometimes less accurate) in tasks that require reasoning in situations in which the experimental stimuli are consistent with scientific but inconsistent with initial conceptions compared to cases where scientific and initial conceptions are consistent with each other. For example, Babai and Amsterdamer (2008) found that ninth graders were less accurate and slower when they classified as solids non-rigid solids (e.g., wax) and powders (e.g., salt) compared to rigid solids (e.g., diamonds), and as liquids dense liquids (e.g., honey) compared to runny ones (e.g., milk). Similarly, Potvin, Masson, Lafortune, and Cyr (2014) showed that secondary school students take more time to decide which of two objects will sink when the correct response involves the lighter as opposed to the heavier object, going against the common misconception that 'heavier objects sink more'. These results have been interpreted to indicate that initial (also known as naïve or intuitive) concepts co-exist with scientific ones and interfere in their employment. It has also been suggested that the extra time required in the employment of such scientific concepts is used to inhibit the interfering initial concept.

In another series of experiments Kelemen and her colleagues examined whether under speeded conditions adults endorse teleological - or purpose-based - explanations of natural phenomena of the kind that are commonly given by children. Children often attribute intentional causality to explain natural phenomena and endorse teleological over physicalcausal explanations, such as that rocks are pointy so that animals won't sit on them. Adults overgrow such purposebased initial explanations but do not seem to completely replace them with physical-causal ones. Kelemen and Rossett (2009) found that undergraduates accepted significantly more scientifically unwarranted teleological explanations (such as that the sun radiates heat because warmth nurtures life) under speeded conditions compared to moderate or unspeeded conditions, concluding that schooled adults preserve the tendency to see purpose in nature and to exhibit this tendency when executive control is poor. In subsequent research Kelemen, Rottman \& Seston (2013) showed that academic scholars in the humanities as well as actively publishing physical scientists in leading US universities, who explicitly rejected unwarranted teleological explanations about nature, nevertheless endorsed them under speeded conditions, indicating that there is a threshold to the revision of agentive and intentional conceptualizations of nature. Shtulman and Valcarcel (2012) also tested the co-existence hypothesis not in one but in 10 different domains of knowledge from the life sciences to the physical sciences to mathematics. Their results showed that undergraduates verified statements whose truth value differed across naïve and scientific theories significantly less accurately and more slowly than statements whose truth value was the same across both theories, suggesting that the co-existence of naïve and scientific theories extends across multiple domains of knowledge.

Similar results have been obtained in the domain of mathematics learning. In two experiments, DeWolf and Vosniadou (2015) investigated the effects of the whole number bias in timed fraction magnitude comparison tasks with skilled adults. The whole number bias refers to the application of whole number knowledge in situations in which this is not appropriate (see Ni \& Zhou, 2005). The results showed that both accuracy and response time depended on whether the fraction magnitudes were consistent or not with whole number ordering indicating that even skilled adults do not have direct access to the fraction magnitudes on the number line when the distance between the fraction pairs is very small. These results are consistent with the findings of other experiments which show that the whole number parts of which fractions are composed (the numerator and denominator) interfere with their processing (see Meert Grégoire, \& Noël, 2009, 2010; Obersteiner et al., 2013; Vamvakoussi, Van Dooren, \& Verschaffel, 2012). In a series of studies that used intensive training Kallai and Tzelgov $(2009,2012)$ found that despite that fractional values could be learned to be processed efficiently, the process did not reach automaticity. On the contrary, the whole number fraction components interfered and in fact dominated the automatic processing.

\section{The role of EF skills in the employment of science and mathematics concepts which require conceptual changes}

If initial concepts co-exist with scientific and mathematical concepts, it makes sense to hypothesize that the employment of such concepts should depend on cognitive processes that require continuous comparisons between them, the adoption of different perspectives, the adjustment of decision making to changing contexts, the ability to keep information in working memory, extensive attention, and the inhibition of initial concepts when necessary. All these cognitive processes depend heavily on the recruitment of EF skills such as working memory, shifting, and inhibition. Working memory would be required to keep the two concepts/ representations/explanations in mind and continuous 
shifting to compare them and decide which one to use in the current context. Finally, inhibitory control would be needed to suppress the inappropriate representation.

Although there are good theoretical reasons to hypothesize that all EF skills would be recruited in the construction and employment of science and mathematics concepts, most of the empirical research has focused on the investigation of the role of inhibition, for reasons that are explained below. In the pages that follow the relevant research will be reviewed.

\subsection{The role of inhibition}

Inhibitory control has been specifically related to conceptual change in science and mathematics learning because the construction of new representations and new ontological categories in these areas often requires overcoming the strong pull of initial belief systems (Babai, Younis, \& Stavy, 2014; Masson et al., 2014; Van Dooren \& Inglis, 2015). Preliminary results coming from neuroimaging studies indicate that there might be differences in brain activation between novices and experts when they must evaluate counter-intuitive scientific stimuli. Experts seem to activate brain areas involved in inhibition, indicating that they are actively suppressing contradictory evidence to answer scientifically (Fugelsang \& Mareschal, 2014). Masson et al., (2014) used functional magnetic resonance imaging (fMRI) to compare brain activation in experts and novices when evaluating the correctness of simple electric circuits. The results showed that experts more than novices activate brain areas involved in inhibition when evaluating erroneous stimuli, suggesting that they are suppressing misconceptions encoded in the neural networks of their brain.

Behavioral studies in mathematics learning have also shown that inhibitory control is significantly related to general mathematics achievement (e.g., Blair \& Razza, 2007; Bull \& Scerif, 2001; Espy et al., 2004; St. Clair-Thompson \& Gathercole, 2006; Siegler \& Pyke, 2013). Siegler and Pyke (2013) found relations between general mathematics achievement and inhibitory control in sixth and eighth grade students, while Gilmore et al. (2013) found that inhibition was related to mathematical procedural knowledge in younger participants and conceptual knowledge in older participants (see also Cragg et al., 2017).

\subsection{Behavioral evidence for the recruitment of inhibition in conceptual change processes}

Is there any behavioral evidence to support the hypothesis that inhibition is recruited in the employment of science and mathematics concepts which require conceptual changes for their construction? An explicit link between inhibition and a type of conceptual change learning has been shown in an experiment which investigated the employment of linear vs. logarithmic number estimations in adults (Laski \& Dulaney, 2015).

Research has shown a change from logarithmic to linear number estimations with age. For example, kindergarten children produce number line estimates of numbers ranging from 0 to 100 that are better fit by a logarithmic function than by linear one, while second graders produce number line estimates that are better fit by a linear function (Booth \& Siegler, 2006; Opfer \& Thompson, 2008). The development of new representations of numerical magnitude has not been treated as an instance of conceptual change learning by Sielger and his colleagues, but it does meet the definition of conceptual change discussed earlier, namely, learning that requires the substantial revision of prior knowledge, and the creation of new representations.

Laski and Dulaney (2015) argued that adults activate both linear and logarithmic number estimations and that the employment of a linear numerical representations requires the suppression of the interfering logarithmic one. To test this hypothesis, they compared the performance of adult participants in an easy and familiar number line estimation task, with standard endpoints involving powers of 10 $(0-1,000)$ and one with unfamiliar, non-standard endpoints (364-1,364). The results showed that the participants generated estimates with greater fit to the logarithmic function on the non-standard number line task compared to the standard one. This result was interpreted to support the hypothesis that adults possess both kinds of representations and activate the initial, logarithmic one when confronted with difficult tasks. The results also showed that the adults' ability to inhibit numerical responses in a number-quantity Stroop task was related to the degree to which their estimates fit the logarithmic function in the case of the non-standard number line task, even when the tendency to use logarithmic representations on number lines with standard number line tasks was controlled for.

In summary, the results of the studies reviewed so far show longer reaction times in the employment of science and mathematics concepts when they are inconsistent as opposed to consistent with an initial concept that contradicts them. This result suggests that the participants need the extra time to inhibit the interfering initial concepts.

The above raise several questions regarding the relation between conceptual change learning and EF skills, such as the following: 1) Is inhibition the only EF skill recruited in the employment of science and mathematics concepts that require conceptual changes for their construction? 2) Is inhibition recruited in the employment of science and mathematics concepts in situations in which there is no need to reject a conflicting initial concept? In an attempt to start answering some of these questions we conducted a series of studies which compared the performance of elementary and high school students in two online conceptual understanding and change (CU\&C) reaction time tasks and two Stroop-like EF tasks (Vosniadou et al., 2015, in press, submitted).

\subsection{Studies in our lab}

The CU\&C tasks investigated conceptual change learning in 3 areas of science (physics, biology and chemistry and one area of mathematics (rational number). The Re-Categorization 
task (Re-Cat) investigated individuals' ability to categorize a target concept (a word or a number) in initial or scientific categories. The Sentence-Picture Verification task (Sp-Ver) investigated individuals' abilities judge the truth or falsity of initial (common-sense) vs. scientific statements in relation to a situation in the world (picture) to which they referred. The statements were either consistent with both initial and scientific views or inconsistent with one of them. Examples from the mathematics items of the two tasks can be found in figures 1 and 2 .
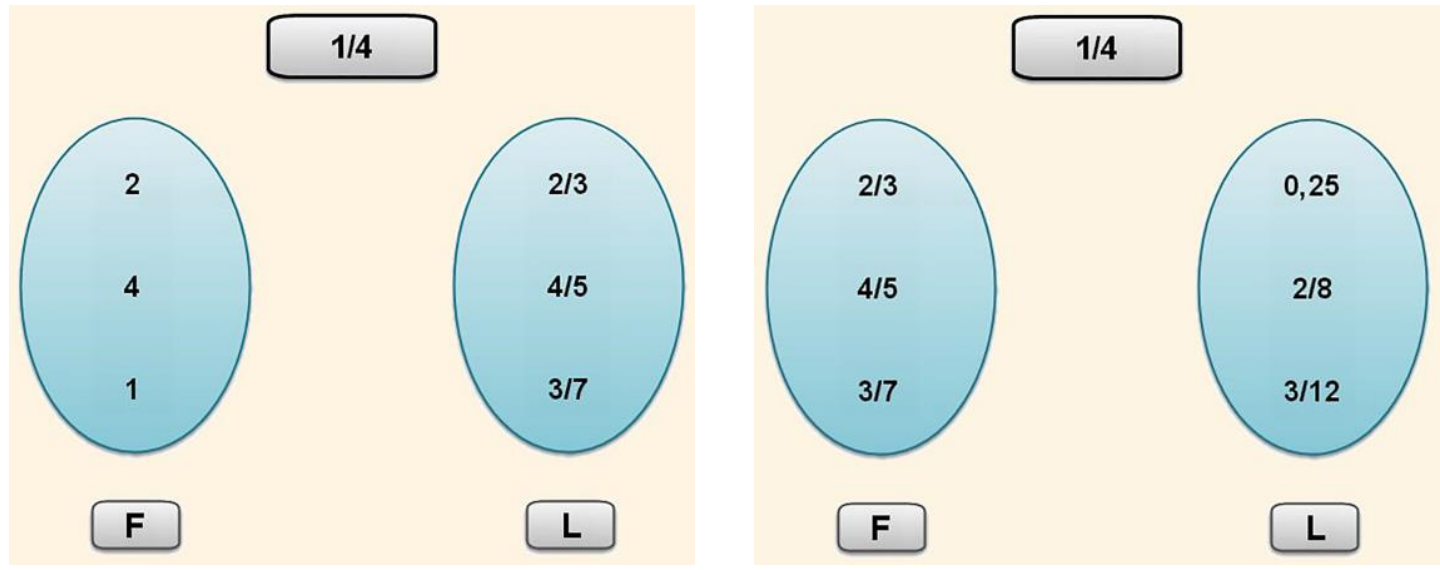

Figure 1. Examples from the mathematics items of Re-Cat task in the initial and scientific conditions

\begin{tabular}{|c|c|c|c|}
\hline $\begin{array}{l}\text { True Initial/ } \\
\text { True Scientific }\end{array}$ & $\begin{array}{l}\text { False Initial/ } \\
\text { False Scientific }\end{array}$ & $\begin{array}{l}\text { True Initial/ } \\
\text { False Scientific }\end{array}$ & $\begin{array}{l}\text { False Initial/ } \\
\text { True Scientific }\end{array}$ \\
\hline $2 / 3$ is larger than $1 / 3$ & $2 / 4$ is larger than $3 / 4$ & $1 / 7$ is larger than $1 / 5$ & $1 / 3$ is larger than $1 / 5$ \\
\hline$\frac{2}{3}>\frac{1}{3}$ & $\frac{2}{4}>\frac{3}{4}$ & $\frac{1}{7}>\frac{1}{5}$ & $\frac{1}{3}>\frac{1}{5}$ \\
\hline & $y=0$ & & YES \\
\hline
\end{tabular}

Figure 2. Examples from the mathematics items of the SP-Ver task in the two consistent and two inconsistent conditions

The Sp-Ver and Re-Cat tasks were validated by experts and by primary and secondary school students and were administered to 512 participants, ranging in age from elementary school students to university undergraduates (Vosniadou et al., submitted). CFAs on both accuracy and reaction times revealed that both tasks converged into two second-order factors - initial and scientific - and a common third order factor - conceptual understanding and conceptual change. The results also showed that the participants were less accurate and took more time to categorize the target concept in the scientific compared to the initial conditions of the Re-Cat and to verify the sentence/picture combinations in the consistent compared to the inconsistent conditions of the Sp-Ver.
The first study (Vosniadou et al., 2015) investigated whether performance in the two combined CU\&C tasks would be predicted by the participants' performance in two EF tasks, which investigated inhibition and shifting in three modes (verbal, spatial, and numerical). Shifting was investigated because the tasks required the comparison of initial and scientific stimuli and we hypothesized that shifting might be recruited. The participants were $694^{\text {th }}$ and $6^{\text {th }}$-grade children. Only accuracy performance was investigated. A path model showed that accuracy performance in the combined scores of the incongruent conditions of the two EF tasks predicted accuracy performance in both the initial/consistent and the scientific/inconsistent trials of the combined CU\&C tasks. Accuracy performance was also 
predicted by intellectual ability measured by Raven's Progressive Matrices (Raven, Court, \& Raven, 1985), while EF and the Raven were correlated with each other. A prediction analysis (Froman \& Hubert, 1980) confirmed that the participants at the high and medium percentile of EF accuracy were much more likely to be high achievers in the conceptual change tasks compared to the participants in the low percentile of EF accuracy.

A subsequent study with $1334^{\text {th- }}$ and $6^{\text {th }}$-grade children investigated in greater detail the distinct roles of inhibition and shifting in the employment of scientific and mathematical concepts in the two conceptual change tasks separately (Vosniadou et al., in press). The two conceptual change tasks used in Vosniadou et al. (2015) were different in some important respects. The Sentence-Picture Verification task (thereafter Sp-Ver) was similar in kind to tasks used in previous research. As mentioned earlier, in this task the participants were asked to verify sentence-picture combinations in a consistent and an inconsistent condition. In the consistent condition, the scientific statements and the corresponding pictures were consistent with an initial, common-sense concept (they were both either true or false). In the inconsistent condition, the scientific statements and pictures were inconsistent with an initial concept (when one was true, the other was false). In the inconsistent condition the acceptance of the scientific statement required the participants to reject the initial, common-sense statement as false. Thus, in the Sp-Ver, the task demands differed between the experimental and control conditions. This was not, however, the case in the Re-Cat task.

The Re-Categorization task (thereafter Re-Cat) was different from the tasks used in previous research. In this task, the participants were presented with a target concept and were asked to decide to which of two categories it belonged best. In the initial condition, the participants had to decide between two categories that represented initial, commonsense, categorizations. In the scientific condition, they had to decide between two categories that represented an initial and a scientific categorization. Thus, in the Re-Cat the task demands were the same in the experimental and control conditions. In both cases, the participants had to compare the items that belonged to two different categories and decide which one is more similar to the target concept. In both cases, one of these two categories was better than the other and selection of one did not necessitate the falsification of the other. Both could be true.

The question of interest was whether the difference in task demands in the $\mathrm{Re}$-Cat and Sp-Ver would influence the cognitive processes involved and therefore the EF skills employed. In the Sp-Ver task, accurate performance in the experimental but not in the control condition required the rejection of the initial concept as false. As such, we would expect the recruitment of inhibition in the experimental condition of this task only. In the Re-Cat task, the participants in both the experimental and control conditions had to compare the items in the two categories and decide to which category the target item belonged. While one category was always better than the other (based on the $100 \%$ agreement of experts) the selection of one category did not require the concomitant rejection of the other as false. As such, we would expect that shifting and maybe inhibition would be recruited in both the experimental and the control conditions in this task.

A regression analysis showed that inhibition was recruited only in the experimental condition of the Sp-Ver task, in which the rejection of the initial, common-sense statement was required. In this task inhibition accuracy predicted $\mathrm{Sp}-$ Ver accuracy. Shifting was recruited in all the tasks. Shifting accuracy predicted accuracy performance and RTs predicted RTs in both conditions of the Re-Cat task and in the consistent condition of the Sp-Ver task. Additionally, shifting RTs predicted accuracy performance in the experimental condition of the Sp-Ver task. In other words, the participants who were faster in shifting were significantly more likely to reject the initial, common-sense concepts in favor of the scientific ones. We interpreted this finding to mean that cognitive flexibility is important in this case because it gives more time to the executive system to inhibit the incorrect response (Vosniadou et al., in press). It should be mentioned here that the cognitive demands of the Sp-Ver task were significant and it is probable that working memory was also recruited. Future research will need to investigate the role of working memory in conceptual change tasks.

The above results were replicated in a third experiment with $2037^{\text {th }}$ - and $9^{\text {th }}$-grade students (Pnevmatikos et al., in preparation). The results again showed greater accuracy and slower RTs in the initial and consistent conditions than in the scientific and inconsistent conditions in the Re-Cat and SpVer tasks respectively. However, a trade-off was also observed between accuracy and RTs. A significant condition by grade interaction showed that the participants increased their accuracy in the inconsistent condition of the Sp-Ver but not in the consistent condition. At the same time RTs became faster with age in the initial condition of the Re-Cat and the consistent condition of the Sp-Ver. For a more in-depth investigation of this trade-off, an efficiency performance score was constructed based on the accuracy/RT ratio (i.e., the proportion of the accurate responses to the time spent to complete each item). A series of regression analyses showed that inhibition was the predictor only for the inconsistent condition of the Sp-Ver task. Shifting was the predictor of efficiency performance in both conditions of the Re-Cat task and the consistent condition of the Sp-Ver.

To conclude and summarize, the results of the three experiments reviewed above showed that different cognitive processes were involved in the two tasks and that these processes recruited different EF skills. Inhibition was recruited specifically in the tasks in which the employment of the scientific concepts required the rejection of a contradictory initial concept as false. This result suggests that inhibition might be a more specialized EF skill that is recruited in certain kinds of conceptual change processes in which the rejection of initial, common-sense concepts or explanations is required. In these kinds of tasks, the speed of 
shifting was also an important predictor of performance. Shifting was recruited in all the tasks in both the scientific and the initial conditions, suggesting that it is a more general EF skill important for tasks that require the making of comparisons, the detection of anomalies and the employment of different perspectives.

Future research needs to also investigate the recruitment of working memory in conceptual change tasks.

\section{The role of $E F$ in the construction of science and mathematics concepts that require conceptual changes}

Carey and her colleagues (Carey, Zaitchik, \& Bascandziev, 2015; Zaitchik, Iqbal, \& Carey, 2013) have argued that the construction of concepts that require conceptual change is different from the construction of concepts which do not. Cases of conceptual change, they claim, require specific cognitive mechanisms to be accomplished, such as bootstrapping, i.e., a cognitive process that involves a kind of analogical reasoning, and these are the cognitive mechanisms that make heavy demands on EF skills. The argument for distinguishing the mechanisms that make conceptual change possible from the mechanisms that involve the accretion of facts is further strengthened by empirical evidence from studies of adults with Williams syndrome (a neurological disorder that causes mental retardation but allows for the development of language and factual knowledge). Adults with Williams syndrome fail to acquire a vitalist biology but develop normal factual biological understanding (Johnson \& Carey, 1998). According to Carey et al., (2015; see also Zaitchik et al., 2013) the construction of vitalist biology in elementary school children constitutes an instance of conceptual change, over a previous agent-centered understanding of life by preschool children (see also Carey, 1985; Johnson \& Carey, 1998; Carey et al., 2015). Young children identify life with movement and activity and thus attribute it only to animals and people (as well as to some inanimate objects that appear to be causal and intentional agents, like the Sun and the Moon) but not to plants. The construction of a vitalist biology requires considerable conceptual changes in preschool children's agent-based theory of life, including the differentiation of alive from active and dead, of animate from inanimate and the coalescence of animal and plant into the single ontological category of living thing. Zaitchick et al. (2014) hypothesized the reason why adults with Williams syndrome do not construct a vitalist biology is impairment in the mechanisms of EF and that these very EF mechanisms are necessary for the construction and expression of theoretical knowledge.

Is there any behavioral evidence for the recruitment of EF skills in the construction of science and mathematics concepts that require conceptual change? Zaitchik et al., (2013) investigated the hypothesis that individual differences in EF skills can explain, at least partly, the construction of a vitalist biology in young children. Their participants were 79 children, ranging in age from 5 to 7 years. The results showed that the children's scores in a battery of EF tasks significantly predicted their vitalist biology knowledge, even after controlling for age and verbal IQ. Although this study confirmed that there is a relation between EF skills and vitalistic biology, it was inconclusive as to whether the EF skills tested were recruited in the construction of biological knowledge or in the demonstration or employment of this biological knowledge after it had been constructed. Furthermore, the EF tasks (Hearts \& Flowers, Flanker Fish, and Color Words) and measures used (a combined measure of accuracy in some of the conditions and failures to respond to stimulus) were not exact enough to draw inferences as to which specific EF skill might have been involved.

Laski and Dulaney (2015) in the paper discussed earlier which investigated the employment of linear vs. logarithmic numerical investigations, also investigated the hypothesis that individual differences in inhibitory control are related to the rate to which children benefit from instruction relevant to number estimation. They hypothesized that the children with better inhibitory control are better at inhibiting their bias towards the logarithmic representation more readily in order to construct a linear representation. Their results showed that individual differences in inhibitory control did predict the rate at which playing a numerical board game improved number line estimates in children. The children with above average inhibitory control demonstrated rapid improvement in the linearity of their number line estimates as opposed to children with below average inhibitory control who demonstrated no improvement. This relation between inhibitory control and learning existed after controlling for pretest estimation performance.

Although this study is correlational in nature, it suggests that inhibitory control is recruited in the construction of linear representations of numerical magnitude in off-line tasks. A limitation of the study is that it did not control for the influence of other EF skills such as shifting and working memory, and other factors such as IQ. More importantly, it did not test whether there are causal relations between inhibition and numerical line estimation.

\section{Implications for Education}

Our studies of conceptual change in science and mathematics (see Vosniadou \& Skopeliti, 2013) show that it might not be necessary to posit qualitatively different cognitive mechanisms to account for the construction or employment of science and mathematics concepts that require conceptual changes. Considerable knowledge revision can be achieved by relying on the use of constructive, additive cognitive mechanisms. However, it is possible that the cognitive mechanisms that produce knowledge revision place heavier quantitative demands on the efficient use of EF skills and specifically of inhibitory control. While inhibition might be used in many other instances of learning, it seems to carry important weight in the kind of learning that requires the suppression of what is known in order to learn something new. 
This hypothesis is supported by research indicating that conceptual change learning does not usually take place through radical, Gestalt type knowledge restructurings but is a slow and gradual affair. It appears that one way children might eventually produce conceptual change learning is by constructing new beliefs and new mental representations gradually by adding the new, incompatible scientific information to what they already know, often producing misconceptions. This gradual, constructive learning process does nevertheless require that some prior beliefs are rejected as false or are accepted as belonging to a different explanatory framework. Such evidence can be found, for example, in Wiser and Smith's (2008) description of the development of children's understanding of matter, Vosniadou and Brewer's $(1992,1994)$ description of the development of children's representations of the shape of the Earth and of the day/night cycle, Evans' (2008) description of developmental changes in children's biological explanations as well as in Shtulman's (2006) account of the subtle differences in adults' understanding of evolution.

The research reviewed in this paper shows that EF skills such as inhibition and shifting are recruited in conceptual change tasks and that inhibition seems to play a unique role in the cases in which scientific information is inconsistent with initial concepts and requires their rejection as false. However, causal relations have not been established. In order to do so, studies are required which will provide training in inhibition and/or other EF skills and then examine whether subsequent improvements in the EF skills provided have an effect on the construction and employment of science and mathematics concepts in conceptual change tasks.

Existing research has shown that although inhibitory control and other EF skills can be improved through training (Diamond, 2012), the effects of this type of training are limited and do not often transfer even to different, non-trained, inhibition tasks (Kray \& Ferdinand, 2013). On the other hand, there is also evidence that the learning environment can influence the development of EF skills (see Zelazo, Blair, \& Willoughby, 2016). Thus, there might be a bi-directional causal relation between EF skills and the learning of counterintuitive science and math concepts, such as that improvement in one can have positive effects on the other. Reviews of the effectiveness of training studies agree in general with the recommendation that more generalized benefits are likely to result when EF training is embedded within the curriculum (Diamond \& Lee, 2011; Holmes \& Gathercole, 2013). Future research needs to carefully investigate the effects of different kinds of EF training on the construction and employment of science and mathematics concepts that require conceptual changes. This might open a new path of effective interventions in school settings aiming at the early integration of executive function training with the teaching of science and mathematics in order to improve students' learning and academic achievement.

\section{References}

Allan, N. P., Hume, L. E., Allan, D. M., Farrington, A. L., \& Lonigan, C. J. (2014). Relations between inhibitory control and the development of academic skills in preschool and kindergarten: A meta-analysis. Developmental Psychology, 50(10), 2368-2379. https://doi.org/10.1037/a0037493

Babai, R., \& Amsterdamer, A. (2008). The persistence of solid and liquid naive conceptions: A reaction time study. Journal of Science Education and Technology, 17(6), 553559. https://doi.org/10.1007/s10956-008-9122-6

Babai, R., Younis, N., \& Stavy, R. (2014). Involvement of inhibitory control mechanisms in overcoming intuitive interference. Neuroeducation, 3(1), 1-9. https://doi.org/10.24046/neuroed.20140301.1

Bell, M. A., \& Fox, N. A. (1992). The relations between frontal brain electrical activity and cognitive development during infancy. Child Development, 63(5), 1142-1163. https://doi.org/10.2307/1131523

Blair, C., \& Razza, R. P. (2007). Relating effortful control, executive function, and false belief understanding to emerging math and literacy ability in kindergarten. Child Development, 78(2), 647-663. https://doi.org/10.1111/j.1467-8624.2007.01019.x

Booth, J. L., \& Siegler, R. S. (2006). Developmental and individual differences in pure numerical estimation. Developmental Psychology, 42(1), 189-201. https://doi.org/10.1037/0012-1649.41.6.189

Bull, R., Espy, K. A., \& Wiebe, S. A. (2008). Short-term memory, working memory, and executive functioning in preschoolers: Longitudinal predictors of mathematical achievement at age 7 years. Developmental Neuropsychology, 33(3), 205-228. https://doi.org/10.1080/87565640801982312

Bull, R., \& Scerif, G. (2001). Executive functioning as a predictor of children's mathematics ability: Inhibition, switching, and working memory. Developmental Neuropsychology, 19(3), 273-293. https://doi.org/10.1207/s15326942dn1903_3

Caravita, S., \& Halldén, O. (1994). Re-framing the problem of conceptual change. Learning and Instruction, 4(1), 89-111. https://doi.org/10.1016/0959-4752(94)90020-5

Carey, S. (1985). Conceptual change in childhood. Cambridge, MA: MIT Press.

Carey, S., Zaitchik, D., \& Bascandziev, I., (2015) Theories of development: In dialog with Jean Piaget. Developmental Review, 38, 36-54. https://doi.org/10.1016/j.dr.2015.07.003 
Chi, M. (2013). Two kinds and four sub types of misconceived knowledge, ways to change it and the learning outcomes. In S. Vosniadou (Ed.) International Handbook of Research on Conceptual Change ( $2^{\text {nd }}$ ed, pp. 49-71). New York, NY: Routledge. https://doi.org/10.4324/9780203154472.ch3

Cragg, L., Keeble, S., Richardson, S., Roome, H. E., \& Gilmore, C. (2017). Direct and indirect influences of executive functions on mathematics achievement. Cognition, 162, 12-26. https://doi.org/10.1016/j.cognition.2017.01.014

DeWolf, M., \& Vosniadou, S. (2015). The representation of fraction magnitudes and the whole number bias reconsidered. Learning and Instruction, 37, 39-49. https://doi.org/10.1016/j.learninstruc.2014.07.002

Diamond, A. (2012). Activities and programs that improve children's executive functions. Current Directions in Psychological Science, 21(5), 335-341. https://doi.org/10.1177/0963721412453722

Diamond, A., \& Lee, K. (2011). Interventions shown to aid executive function development in children 4 to 12 years old. Science, 333(6045), 959-964. https://doi.org/10.1126/science.1204529

Espy, K. A., McDiarmid, M. M., Cwik, M. F., Stalets, M. M., Hamby, A., \& Senn, T. E. (2004). The contribution of executive functions to emergent mathematic skills in preschool children. Developmental Neuropsychology, 26(1), 465-486. https://doi.org/10.1207/s15326942dn2601_6

Evans, E. M. (2008). Conceptual change and evolutionary biology: A developmental analysis. In S. Vosniadou (Ed.), International Handbook of Research on Conceptual Change (pp. 263-294) New York, NY: Routledge.

Evans, E. M., \& Lane, J. D. (2011). Contradictory or complementary? Creationist and evolutionist explanations of the origin (s) of species. Human Development, 54(3), 144-159. https://doi.org/10.1159/000329130

Froman, T., \& Hubert, L. J. (1980). Application of prediction analysis to developmental priority. Psychological Bulletin, 87(1), 136-146. https://doi.org/10.1037/0033-2909.87.1.136

Fugelsang, J., \& Mareschal, D. (2014). The development and application of scientific reasoning. In D. Mareschal, B. Butterworth \& A. Tolmie (Eds.), Educational Neuroscience (pp. 237-267). Chichester, UK: Wiley-Blackwell.

Fuster, J. M. (2015). The prefrontal cortex ( $5^{\text {th }}$ ed.). London, UK: Academic Press.

Gilmore, C., Attridge, N., Clayton, S., Cragg, L., Johnson, S., Marlow, N., \& Inglis, M. (2013). Individual differences in inhibitory control, not non-verbal number acuity, correlate with mathematics achievement. PloS One, 8(6), e67374. https://doi.org/10.1371/journal.pone.0067374

Holmes, J., \& Gathercole, S. E. (2013). Taking working memory training from the laboratory into schools. Educational Psychology, 34(4), 440-450.

https://doi.org/10.1080/01443410.2013.797338
Inagaki, K., \& Hatano, G. (2004). Vitalistic causality in young children's naive biology. Trends in Cognitive Sciences, 8(8), 356-362. https://doi.org/10.1016/j.tics.2004.06.004

Jacob, R., \& Parkinson, J. (2015). The potential for schoolbased interventions that target executive function to improve academic achievement: A review. Review of Educational Research, 85(4), 512-552. https://doi.org/10.3102/0034654314561338

Johnson, S. C., \& Carey, S. (1998). Knowledge enrichment and conceptual change in folkbiology: Evidence from Williams syndrome. Cognitive Psychology, 37(2), 156-200. https://doi.org/10.1006/cogp.1998.0695

Kallai, A. Y., \& Tzelgov, J. (2012). When meaningful components interrupt the processing of the whole: The case of fractions. Acta Psychologica, 139(2), 358-369. https://doi.org/10.1016/j.actpsy.2011.11.009

Kallai, A. Y., \& Tzelgov, J. (2009). A generalized fraction: An entity smaller than one on the mental number line. Journal of Experimental Psychology: Human Perception and Performance, 35(6), 1845-1864.

https://doi.org/10.1037/a0016892

Kelemen, D., \& Rosset, E. (2009). The human function compunction: Teleological explanation in adults. Cognition, 111(1), 138-143. https://doi.org/10.1016/j.cognition.2009.01.001

Kelemen, D., Rottman, J., \& Seston, R. (2013). Professional physical scientists display tenacious teleological tendencies: Purpose-based reasoning as a cognitive default. Journal of Experimental Psychology: General, 142(4), 1074-1083. https://doi.org/10.1037/a0030399

Kieffer, M.J., Vukovic, \& Berry, D. (2013). Roles of Attention Shifting and Inhibitory control in fourth-grade reading comprehension. Reading Research Quarterly, 48(4), 333348. https://doi.org/10.1002/rrq.54

Kray, J., \& Ferdinand, N. K. (2013). How to improve cognitive control in development during childhood: Potentials and limits of cognitive interventions. Child Development Perspectives, 7(2), 121-125. https://doi.org/10.1111/cdep.12027

Laski, E. V., \& Dulaney, A. (2015). When prior knowledge interferes, inhibitory control matters for learning: The case of numerical magnitude representations. Journal of Educational Psychology, 107(4), 1035-1050. https://doi.org/10.1037/edu0000034

Legare, C. H., Evans, E. M., Rosengren, K. S., \& Harris, P. L. (2012). The coexistence of natural and supernatural explanations across cultures and development. Child Development, 83(3), 779-793.

https://doi.org/10.1111/j.1467-8624.2012.01743.x 
Legare, C. H., \& Gelman, S. A. (2009). South African children's understanding of AIDS and flu: Investigating conceptual understanding of cause, treatment and prevention. Journal of Cognition and Culture, 9(3), 333-346. https://doi.org/10.1163/156770909x12518536414457

Legare, C. H., \& Gelman, S. A. (2008). Bewitchment, biology, or both: The co-existence of natural and supernatural explanatory frameworks across development. Cognitive Science, 32(4), 607-642. https://doi.org/10.1080/03640210802066766

Lyons, K. E., \& Zelazo, P. D. (2011). Monitoring, metacognition, and executive function: Elucidating the role of selfreflection in the development of self-regulation. In J. B. Benson (Ed.), Advances in Child Development and Behavior (Vol. 40, pp. 379-412). London, UK: Academic Press. https://doi.org/10.1016/b978-0-12-386491-8.00010-4

Masson, S., Potvin, P., Riopel, M., \& Brault Foisy, L.-M. (2014). Differences in brain activation between novices and experts in science during a task involving a common misconception in electricity. Mind, Brain, and Education, 8(1), 44-55. https://doi.org/10.1111/mbe.12043

Mayer, D., Sodian, B., Koerber, S., \& Schwippert, K. (2014). Scientific reasoning in elementary school children: Assessment and relations with cognitive abilities. Learning and Instruction, 29, 43-55. https://doi.org/10.1016/j.learninstruc.2013.07.005

Meert, G., Grégoire, J., \& Noël, M. P. (2010). Comparing the magnitude of two fractions with common components: Which representations are used by 10-and 12-year-olds? Journal of Experimental Child Psychology, 107(3), 244-259. https://doi.org/10.1016/j.jecp.2010.04.008

Meert, G., Grégoire, J., \& Noël, M. P. (2009). Rational numbers: Componential versus holistic representation of fractions in a magnitude comparison task. The Quarterly Journal of Experimental Psychology, 62(8), 1598-1616. https://doi.org/10.1080/17470210802511162

Munakata, Y., Snyder, H. R., \& Chatham, C. H. (2012). Developing cognitive control: Three key transitions. Current Directions in Psychological Science, 21(2), 71-77. https://doi.org/10.1177/0963721412436807

Ni, Y., \& Zhou, Y. D. (2005). Teaching and learning fraction and rational numbers: The origins and implications of whole number bias. Educational Psychologist, 40(1), 27-52. https://doi.org/10.1207/s15326985ep4001_3

Obersteiner, A., Van Dooren, W., Van Hoof, J., \& Verschaffel, L. (2013). The natural number bias and magnitude representation in fraction comparison by expert mathematicians. Learning and Instruction, 28, 64-72. https://doi.org/10.1016/j.learninstruc.2013.05.003

Opfer, J. E., \& Thompson, C. A. (2008). The trouble with transfer: Insights from microgenetic changes in the representation of numerical magnitude. Child Development, 79(3), 788-804. https://doi.org/10.1111/j.1467-8624.2008.01158.x
Piaget, J. (1985). The equilibration of cognitive structures. Chicago, IL: University of Chicago Press. (Original work published 1975).

Pnevmatikos, D., Makris, N., Vosniadou, S., Eikospentaki, K., Lepenioti, D., Chountala, A., \& Kyrianakis, G. (in preparation). Executive Function's involvement in efficient conceptual change processes during adolescence.

Potvin, P., Masson, S., Lafortune, S., \& Cyr, G. (2014). Persistence of the intuitive conception that heavier objects sink more: A reaction time study with different levels of interference. International Journal of Science and Mathematics Education, 13(1), 21-43. https://doi.org/10.1007/s10763-014-9520-6

Preston, J. L., Ritter, R. S., \& Hepler, J. (2013). Neuroscience and the soul: Competing explanations for the human experience. Cognition, 127(1), 31-37.

https://doi.org/10.1016/j.cognition.2012.12.003

Raven, J. C., Court, J. H., \& Raven, J. (1985). A manual for Raven's Progressive Matrices and Vocabulary Scales. London, UK: H.K. Lewis.

Shtulman, A. (2006). Qualitative differences between naïve and scientific theories of evolution. Cognitive Psychology, 52(2), 170-194. https://doi.org/10.1016/j.cogpsych.2005.10.001

Shtulman, A., \& Valcarcel, J. (2012). Scientific knowledge suppresses but does not supplant earlier intuitions. Cognition, 124(2), 209-215. https://doi.org/10.1016/j.cognition.2012.04.005

Siegler, R. S., \& Pyke, A. A. (2013). Developmental and individual differences in understanding of fractions. Developmental Psychology, 49(10), 1994-2004. https://doi.org/10.1037/a0031200

St. Clair-Thompson, H. L., \& Gathercole, S. E. (2006). Executive functions and achievements in school: Shifting, updating, inhibition, and working memory. The Quarterly Journal of Experimental Psychology, 59(4), 745759. https://doi.org/10.1080/17470210500162854

Vamvakoussi, X., Van Dooren, W., \& Verschaffel, L. (2012). Naturally biased? In search for reaction time evidence for a natural number bias in adults. The Journal of Mathematical Behavior, 31(3), 344-355. https://doi.org/10.1016/j.jmathb.2012.02.001

Van de Sluis, S., De Jong, P.F., \& Van der Leij, A. (2007). Executive functioning in children, and its relations with reasoning, reading, and arithmetic. Intelligence, 35(5), 427-449. https://doi.org/10.1016/j.intell.2006.09.001

Van Dooren, W., \& Inglis, M. (2015). Inhibitory control in mathematical thinking, learning and problem solving: a survey. ZDM, 47(5), 713-721. https://doi.org/10.1007/s11858-015-0715-2 
Vosniadou, S. (2013). Conceptual change in learning and instruction: The framework theory approach. In $\mathrm{S}$. Vosniadou (Ed.), International Handbook of Research on Conceptual Change (2nd ed., pp. 11-30). New York, NY. Routledge. https://doi.org/10.4324/9780203154472.ch1

Vosniadou, S., \& Brewer, W. F. (1994). Mental models of the day/night cycle. Cognitive Science, 18(1), 123-183. https://doi.org/10.1016/0364-0213(94)90022-1

Vosniadou, S., \& Brewer, W. F. (1992). Mental models of the earth: A study of conceptual change in childhood. Cognitive Psychology, 24(4), 535-585. https://doi.org/10.1016/0010-0285(92)90018-w

Vosniadou, S., Pnevmatikos, D., Makris, N., Ikospentaki, K., Lepenioti, D., \& Chountala, A. (2015). Executive functions and conceptual change in science and mathematics learning. In L. Carlson, C. Hoelscher, \& T. F. Shipley (Eds.), Proceedings of the 37th Annual Meeting of the Cognitive Science Society, Pasadena, California, USA.

Vosniadou, S., Pnevmatikos, D., Makris, N., Ikospentaki, K., Lepenioti, D., Chountala, A., \& Kyrianakis, G. (submitted). More on the co-existence of scientific theories and initial belief systems.

Vosniadou, S., Pnevmatikos, D., Makris, N., Ikospentaki, K., Lepenioti, D., Chountala, A., \& Kyrianakis, G. (in press). The recruitment of shifting and inhibition in on-line science and mathematics tasks. Cognitive Science.
Vosniadou, S., \& Skopeliti, I. (2013). Conceptual change from the framework theory side of the fence. Science and Education, 23(7), 1427-1445. https://doi.org/10.1007/s11191-013-9640-3

Vukovic, R. K., Fuchs, L. S., Geary, D. C., Jordan, N. C., Gersten, R., \& Siegler, R. S. (2014). Sources of individual differences in children's understanding of fractions. Child Development, 85(4), 1461-1476. https://doi.org/10.1111/cdev.12218

Wiser, M., \& Carey, S. (1983). When heat and temperature were one. In D. Gentner, \& A. L. Stevens (Eds.), Mental Models (pp. 267-297). Hillsdale, NJ: Lawrence Erlbaum.

Wiser, M., \& Smith, C. L. (2008). Learning and teaching about matter in grades K-8: When should the atomic-molecular theory be introduced? In S. Vosniadou (Ed.), International Handbook of Research on Conceptual Change (pp. 205239). New York, NY: Routledge.

Zaitchick, D., Iqbal, Y., \& Carey, S. (2013). The effect of executive function on biological reasoning in young children: an individual differences study. Child Development, 85(1), 160175. https://doi.org/10.1111/cdev.12145

Zelazo, P. D., Blair, C. B., \& Willoughby, M. T. (2016). Executive function: Implications for education (NCER 2017-2000). Washington, DC: National Center for Education Research Institute of Education Sciences, U.S. Department of Education. 


\title{
Entrainement au contrôle inhibiteur et apprentissage en chimie dans le secondaire supérieur : Favoriser un changement de prévalence conceptuelle
}

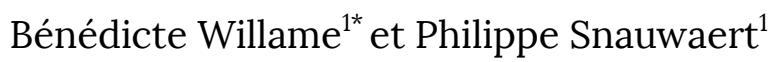

\begin{abstract}
RÉSUMÉ
L'apprentissage des modèles chimiques n'est pas simple d'autant plus que le passage du niveau macroscopique au niveau microscopique de la matière est compliqué par l'utilisation de représentations symboliques. Une habitude intuitive telle que « More A then more B » souvent utilisée chez les plus jeunes apprenants peut être abandonnée par les plus experts en chimie au profit de l'utilisation, parfois erronée, de modèles chimiques proposés lors du cursus scolaire. Dans le contexte de la dissolution d'un soluté dans un solvant, cette habitude est pourtant la stratégie de réponse efficace pour acquérir que le volume de solution est supérieur au volume de solvant et pouvoir ainsi calculer correctement la concentration en soluté (grandeur qui se rapporte au volume de solution). Notre recherche vise à améliorer l'apprentissage de ce concept, grandeur fondamentale en chimie. Nous avons élaboré un dispositif didactique expérimental basé sur l'utilisation d'outils permettant un conflit cognitif et un entrainement à la fonction exécutive de contrôle inhibiteur des conceptions non pertinentes dans le contexte de la dissolution d'un sel dans l'eau. L'objectif est de permettre une (ré)activation de la stratégie de réponse « More A then more $B$ » afin de la rendre prévalente dans ce contexte. Cette étude confronte les scores obtenus par deux groupes d'élèves de grade 10 (15-17 ans) : l'un soumis à une activité de remédiation impliquant un conflit perceptocognitif seul et un autre groupe ayant réalisé cette même activité, mais suivie d'un entrainement à l'inhibition des conceptions non pertinentes dans le contexte de la dissolution d'un sel dans l'eau et du calcul d'une concentration. Les résultats obtenus montrent un impact positif du conflit cognitif suivi d'un apprentissage métacognitif à l'inhibition pour l'acquisition d'un concept de chimie pour des élèves du secondaire. Ils mettent également en évidence que des liens cognitifs privilégiés semblent exister lors du changement de prévalence conceptuelle.
\end{abstract}

\footnotetext{
${ }^{1}$ Université de Namur, Unité de didactique de la chimie, Namur, Belgique

* Correspondance avec l'auteure : benedicte.willame@ismcouvin.eu
}

Pour citer cet article : Willame, B. et Snauwaert, P. (2018). Entrainement au contrôle inhibiteur et apprentissage en chimie dans le secondaire supérieur : Favoriser un changement de prévalence conceptuelle. Neuroéducation, 5(2), 73-92.

DOI: https://doi.org/10.24046/neuroed.20180502.73

Reçu le 31 octobre 2017. Révision reçue le 29 avril 2018.

Accepté le 10 mai 2018. Publié en ligne le 19 septembre 2018.

Neuroéducation, 5(2), 73-92

ISSN: 1929-1833

Tous droits réservés (C) 2018 - Association pour la recherche en neuroéducation 


\section{Introduction}

La chimie est une science qui a pour objectif de comprendre et d'expliquer la matière, ses comportements et ses modifications. Acquérir les modèles conçus par les chimistes n'est pas simple d'autant plus que le passage du niveau macroscopique au niveau microscopique en utilisant les représentations iconographiques complique leur apprentissage (Johnstone, 1993; Tsaparlis et Sevian, 2013).

Dans son laboratoire, le chimiste manipule des solutions qu'il prépare en dissolvant un soluté dans un solvant. La grandeur qui lui permet de connaitre la quantité de soluté qu'il a dissout par rapport au volume total de solution est fondamentale. Cette grandeur, appelée concentration chimique, impose au chimiste qui manipule la solution d'être conscient que le volume de solution est supérieur au volume de solvant. Dans un précédent article, nous avons proposé les résultats d'une étude diagnostique qui met en évidence que l'assimilation entre le volume de solvant et celui de solution est récurrente chez les apprenants (Willame et Snauwaert, 2015).

Notre recherche a pour objectif d'élaborer une stratégie didactique permettant de remédier aux difficultés d'apprentissage du concept de concentration chimique. Nous nous situons après l'apprentissage de ce concept. Les outils didactiques tels que ceux envisagés par les courants théoriques du changement conceptuel proposent de créer un conflit cognitif chez l'apprenant en difficulté afin que sa conception erronée soit remplacée par une conception plus conforme au savoir savant (Astolfi et al., 2008).

Limagerie fonctionnelle du cerveau a permis aux neuroscientifiques de mettre en évidence que réaliser un changement de conception consisterait davantage à inhiber les réseaux neuronaux menant à des réponses inappropriées (Houdé, 2004, 2016b; Masson, 2012, 2016). Le modèle récent de prévalence conceptuelle postule que plusieurs conceptions coexisteraient et qu'une inhibition des conceptions non pertinentes dans le contexte de la question permettrait de répondre correctement à la question (Potvin, 2013; Potvin, Sauriol et Riopel, 2015).

L'étude proposée dans cet article confronte les réponses apportées par des élèves à des questions sur la concentration chimique selon qu'ils aient ou non suivi des activités basées sur un conflit cognitif seul ou sur un conflit cognitif suivi d'un entrainement à la fonction exécutive de contrôle inhibiteur des conceptions non pertinentes.

Dans la première partie, nous aborderons les cadres théoriques de notre recherche : tant ceux liés aux modèles utilisés en chimie pour décrire la dissolution d'un soluté dans un solvant que les fondements des outils didactiques et neuroscientifiques qui nous ont permis d'élaborer les activités de remédiation. Dans la seconde partie, après avoir posé les questions de recherche, nous présentons la méthodologie adoptée pour mesurer limpact de nos outils. Les résultats et une discussion ainsi que des propositions pour l'enseignement feront l'objet de la troisième et dernière partie.

\section{Cadres théoriques de la recherche}

2.1 Les modèles chimiques utilisés pour expliquer la dissolution d'un soluté et calculer sa concentration au sein d'une solution

Peu avant d'étudier le concept de concentration, l'élève appréhende d'abord le phénomène de dissolution où un soluté est dissout dans un solvant pour former une solution. Cette dissolution visible au niveau macroscopique s'explique au niveau microscopique par des modèles proposés par les chimistes.

Pour expliquer la dissolution d'un composé ionique comme du sel de cuisine dans l'eau, le chimiste assimile le sel de cuisine à une substance pure, le chlorure de sodium. Les cristaux cubiques observables à l'échelle macroscopique sont décrits à l'échelle microscopique par un réseau d'ions chlorure $\mathrm{Cl}^{-}$et d'ions sodium $\mathrm{Na}^{+}$souvent représenté par l'alternance de boules vertes négatives et de boules noires positives (figure 1a).

La dissolution du chlorure de sodium dans l'eau peut être modélisée par une dissociation des ions du cristal. Les molécules d'eau s'orientent de telle façon que leur pôle négatif interagit avec les ions $\mathrm{Na}^{+}$et leur pôle positif avec les ions $\mathrm{Cl}^{-}$ (figure 1b). L'attraction entre les ions en surface du cristal et les dipôles des molécules d'eau étant supérieure à la force d'attraction électrostatique entre les ions de sodium et de chlorure, les ions $\mathrm{Na}^{+}$et $\mathrm{Cl}^{-}$passent en solution entourés d'une «sphère de solvatation» (figures 1c et 1d) (Arnaud, 1989; Nivaldo, 2011). La place occupée par les ions du sel dissout a fait augmenter le volume initial de liquide. Le volume de solution est supérieur au volume de solvant.

Pour expliquer la dissolution de composés covalents polaires tels que le saccharose (sucre ajouté dans le café) ou l'éthanol (alcool du vin), le modèle établi par les chimistes se réfère à des liaisons intermoléculaires comme les ponts hydrogène entre les pôles du solvant et ceux du soluté.

Pour aborder les niveaux macroscopique et microscopique (ou sous-microscopique), la représentation symbolique est très souvent utilisée en chimie. Les didacticiens de la chimie intègrent totalement cette représentation comme faisant partie des niveaux de savoir en chimie (Johnstone, 1993). Les choix réalisés dans les représentations de la matière sont variés. C'est ainsi que les représentations iconographiques telles que des formes géométriques sont utilisées pour représenter les solutions. Afin de représenter un soluté qui se dissout dans un solvant, la matière est souvent symbolisée par des ronds en deux dimensions (2D) qui, eux-mêmes, représentent des boules en 3D.

Les concentrations massiques et molaires sont celles principalement développées en grades 9 et 10 du secondaire supérieur en Belgique francophone. Celles-ci se définissent comme le rapport entre la masse (concentration massique) ou la quantité de matière (concentration molaire) et le volume de solution. En d'autres termes, la concentration chimique indique une proportion de soluté dans la solution. Il s'agit d'une grandeur intensive.

\footnotetext{
${ }^{1}$ Une grandeur intensive n'est pas dépendante de la taille, de l'étendue du système (Legrand, 2006). En tout point d'un système homogène, la mesure d'une grandeur intensive est identique.
} 


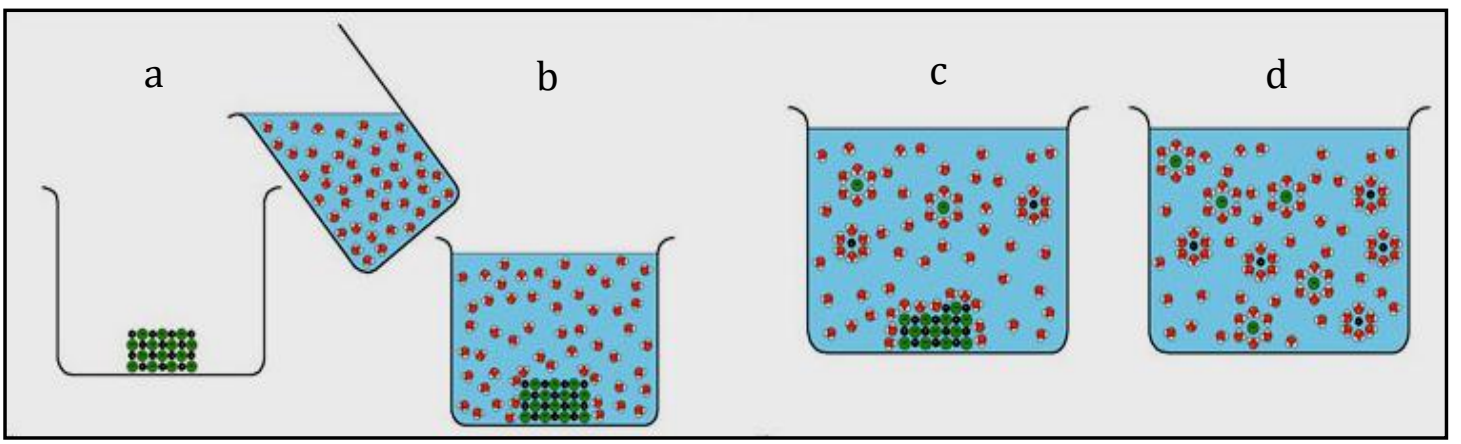

Figure 1. Représentation iconographique du modèle chimique de dissolution du chlorure de sodium dans l'eau (IUPAC, 2016)

La littérature scientifique qui traite de l'apprentissage du concept de concentration étudie principalement les difficultés liées au caractère intensif de la concentration chimique (Gandillet et Le Maréchal, 2003; Khang et Sai, 1987; Tsoumpelis et Gréa, 1995) ou celles liées aux représentations submicroscopiques (SMR) de la matière dissoute dans une solution (de Berg, 2012; Devetak, Vogrinc et Glažar, 2008).

Dans un précédent article (Willame et Snauwaert, 2015), nous avons proposé les résultats d'une étude diagnostique qui met en évidence cinq difficultés récurrentes auxquelles les apprenants sont confrontés lorsqu'ils répondent à des questions sur la concentration chimique. La première est liée au caractère intensif de la concentration chimique, une seconde à la confusion entre le volume de solvant et celui de solution et une troisième, au vocabulaire spécifique utilisé pour exprimer ce concept. Les deux autres sont plus générales aux sciences (erreurs de calculs et choix des unités).

Dans ce présent article, nous nous limitons à présenter les outils didactiques utilisés pour remédier à la confusion entre le volume de solvant et celui de la solution. Le calcul d'une concentration massique ou molaire demande de rapporter la quantité de soluté au volume total de la solution. Pour concrétiser l'erreur commise dans le calcul d'une concentration si le volume occupé par le soluté est négligé, citons cet exemple : le volume de solution après ajout de $100 \mathrm{~g}$ de chlorure de sodium (sel de cuisine) dans $500 \mathrm{~mL}$ d'eau déminéralisée est d'environ $550 \mathrm{~mL}$ à température ambiante ; l'augmentation de volume n'est pas négligeable. En prenant en compte le volume de solution, la concentration massique de chlorure de sodium n'est pas de $200 \mathrm{~g} / \mathrm{L}$ (100 g dans $500 \mathrm{~mL}$ d'eau), mais d'environ $182 \mathrm{~g} / \mathrm{L}$ (100 g dans $550 \mathrm{~mL}$ de solution). L'erreur commise sur le calcul de la concentration massique avoisine donc les $10 \%$.

\subsection{Les conceptions, le changement conceptuel et le changement de prévalence conceptuelle}

\subsubsection{Les conceptions en didactique}

Notre recherche se situe dans le cadre théorique du changement conceptuel. Nous reprenons la définition classique donnée en didactique pour la «conception» comme une construction intellectuelle du sujet qui est mobilisée spontanément face à une question ou un problème. Le sujet se réfère à des systèmes de connaissances pour résoudre une thématique qui a fait l'objet ou non d'un apprentissage (Reuter et al., 2013).

Les conceptions peuvent être exprimées explicitement par les élèves dans leurs productions. Si ce n'est pas le cas, le chercheur doit tenter de les identifier. Or les productions des apprenants sont réalisées dans un contexte particulier ; elles répondent à une question dans des conditions précises. Leur interprétation est donc liée à la fois aux conditions de la production et aussi au filtre qu'exerce le chercheur à travers ses propres cadres conceptuels et ses propres positions théoriques (« hypothèses de représentation », Astolfi, 1992).

Les conceptions des élèves peuvent être compatibles avec les connaissances scientifiques que l'école cherche à enseigner, mais elles peuvent aussi les contredire partiellement ou totalement. Christian Orange et Denise Orange-Ravachol (2013) résument les points importants concernant les apprentissages scientifiques :

L'apprentissage ne se fait pas à partir de rien : l'élève a des façons de penser les questions scientifiques et des connaissances avant enseignement, de sorte que celui-ci ne vise pas simplement à apporter des connaissances mais à changer les conceptions des élèves.

Ces conceptions ont une résistance au changement car elles sont, dans une certaine mesure, cohérentes et efficaces [...]. (p.49-50)

Selon les auteurs, il existe des divergences de vue sur l'origine des conceptions et c'est pourquoi ils proposent des chemins différents pour amener l'apprenant à se rapprocher du concept savant ou tout du moins du concept transposé pour son enseignement.

Tous ces auteurs convergent toutefois vers une idée commune : les élèves ne sont pas passifs, mais construisent leurs propres connaissances (Viennot, 2008). 


\subsubsection{La théorie classique du changement conceptuel}

Le modèle de Posner, Strike, Hewson et Gertzog

Selon George J. Posner, Kenneth A. Strike, Peter W. Hewson et William A. Gertzog (1982), l'apprentissage est pensé comme un « changement conceptuel» (« conceptual change »). Pour proposer ce nouveau paradigme en didactique, ils se basent, entre autres, sur les travaux de l'épistémologiste Thomas S. Kuhn (1983) qui compare les changements de conceptions aux « révolutions scientifiques » (vues comme des « crises ») dans l'histoire des sciences. Ils se basent également sur les travaux du suisse Jean Piaget qui définit le développement d'un individu comme un processus continu, progressif et évolutif dirigé par des nécessités internes d'équilibre. Selon Piaget, l'adaptation de l'individu à son milieu se fait par une dynamique « assimilation » et « accommodation ». L'assimilation est le processus par lequel un objet de l'environnement avec lequel l'individu est en interaction est directement intégré par la structure mentale de celui-ci. Inversement, l'accommodation est le processus par lequel la structure mentale de l'individu se modifie pour s'adapter à son environnement (Houdé, 2004, p. 10).

Ainsi, Posner et al. (1982) pensent que, tout comme le scientifique doit comprendre et expliquer de nouveaux concepts en révisant (en « révolutionnant ») sa façon de voir le monde, l'apprenant doit également s'engager à changer ses conceptions via les processus d'assimilation et d'accommodation.

[T] he scientist must acquire new concepts and a new way of seeing the world. Kuhn terms this kind of conceptual change a "scientific revolution". [...] We believe there are analogous patterns of conceptual change in learning. Sometimes students use existing concepts to deal with new phenomena. This variant of the first phase of conceptual change we call assimilation. Often, however, the students' current concepts are inadequate to allow him to grasp some new phenomenon successfully. Then the student must replace or reorganize his central concepts. This more radical form of conceptual change we call accommodation. (Posner et al., 1982, p. 212)

Selon Posner et al., le changement conceptuel ne peut avoir lieu que si quatre conditions sont réunies. La première condition posée par Posner et al. est l'«insatisfaction »dans le sens où l'apprenant doit être conscient que ses propres conceptions ne permettent plus d'expliquer un nouveau phénomène auquel il est confronté.

Une seconde condition est liée à l'«intelligibilité » des nouvelles conceptions: elles doivent être amenées à l'apprenant de telle façon qu'il soit capable de les comprendre et de se les représenter. Ces mêmes conceptions doivent être «plausibles » c'est-à-dire cohérentes par rapport au problème donné de façon à pouvoir le résoudre. Enfin, la dernière condition est que ces nouvelles conceptions soient «fécondes » c'est-à-dire efficaces pour expliquer d'autres phénomènes. Selon ce modèle, ces quatre conditions sont nécessaires pour permettre l'accommodation. Celle-ci est certes un changement radical à réaliser, mais il se fait graduellement par petits ajustements successifs.

Posner et al. précisent l'écologie du changement conceptuel : en classe, il est impératif d'avoir recours au conflit cognitif, sorte de crise scientifique comme l'entendait Kuhn, pour obtenir l'accommodation.

Jean-Pierre Astolfi, Eliane Darot, Yvette Ginsburger-Vogel et Jacques Toussaint (2008) définissent ainsi le conflit cognitif :

Un conflit cognitif se développe lorsqu'apparaît, chez un individu, une contradiction ou une incompatibilité entre ses idées, ses représentations, ses actions. Cette incompatibilité, perçue comme telle ou, au contraire, d'abord inconsciente, devient la source d'une tension qui peut jouer un rôle moteur dans l'élaboration de nouvelles structures cognitives. (p. 35)

Le modèle de Posner et al. (1982), rejoint celui de Nussbaum et Novick (1982) qui, au même moment, proposent également le conflit cognitif pour permettre le changement conceptuel. D'un point de vue pratique, ces auteurs pensent qu'il est indispensable de produire un déséquilibre chez l'apprenant, une prise de conscience parfois brutale qui lui permette de se rendre compte des limites de ses conceptions. Ils proposent trois étapes à suivre: «(1) exposing alternative frameworks, (2) creating conceptual conflict, (3) encouraging cognitive accommodation 》 (Nussbaum et Novick, 1982, p. 183).

En 1992, Strike et Posner révisent leur modèle trop centré sur les processus cognitifs de l'apprenant et ils ajustent leur idée d'écologie conceptuelle en y incorporant des composantes affectives (comme la motivation) et sociales :

This theory of conceptual change is embedded in a set of epistemological assumptions that are far more generalizable than our application to misconceptions has exploited. These epistemological assumptions suggest that the basic problem of understanding cognitive development is to understand how the components of an individual's conceptual ecology interact and develop and how the conceptual ecology interacts with experience. (Strike et Posner, 1992, p. 155-156)

De plus, les conceptions des élèves étaient initialement vues comme des objets auxquels l'écologie conceptuelle s'appliquait. Strike et Posner les reconnurent comme faisant partie de l'écologie conceptuelle. Selon eux, les conceptions sont un outil de pensée à la disposition de l'individu pour appréhender le monde et peuvent donc en déformer la perception lorsqu'elles sont erronées. Ils préconisent alors de «déraciner» les éléments de l'écologie conceptuelle qui favorisent les conceptions erronées et de les remplacer.

Les modèles «Knowledge-as-theory » et « Knowledge-in-pieces 》

Les modèles qui suivent s'orientent davantage sur l'origine des conceptions des apprenants pour mieux comprendre les processus mentaux à l'origine du changement conceptuel : les conceptions faisant partie de référentiels rigides (modèle 
«Knowledge-as-theory ») et les conceptions comme des habitudes spontanées isolées («Knowledge-in-pieces 》).

Selon Stella Vosniadou, les élèves se construisent très tôt un référentiel relativement rigide formé de présuppositions ontologiques et épistémologiques dans lequel ils chercheront par la suite à inscrire les nouveaux apprentissages (Vosniadou et Brewer, 1992). Ce référentiel serait formé d'un certain nombre de croyances ou «Cadres théoriques naïs » («Framework theory»). Un exemple de cadre théorique naif est : « Ce qui ne se voit plus, n'existe plus » (Potvin, 2011). Pour Stella Vosniadou, le changement conceptuel aura lieu si les modèles mentaux sont révisés par les élèves puis finalement remplacés par les modèles scientifiques reconnus. Pour les défenseurs de cette perspective «Knowledge-as-theory », le conflit cognitif permet le changement conceptuel.

Un autre courant propose le modèle de «Connaissances en pièces » («Knowledge-in-pieces »). Andrea diSessa (1983, 2013) en est l'un des principaux défenseurs. Selon cet auteur, les élèves ne formulent pas leurs conceptions à partir de théories bien élaborées, mais plutôt à partir d'habitudes interprétatives intuitives et élémentaires. Il nomme ces habitudes des «p-prims» ("phenomenological primitives » ou «primitives phénoménologiques »). Les élèves jugent pertinent d'utiliser une $p$-prim sur la seule base des apparences et de leurs impressions afin de produire des explications et prendre des décisions. Ruth Stavy et Dina Tirosh (2000) utilisent le terme «intuitive rules » ("règles intuitives ») pour nommer ces habitudes spontanées. Citons également les «core intuitions » («intuitions de base ») de Brown (1993).

Un exemple de $p$-prim mis en évidence par diSessa (2006) lors de l'apprentissage de la loi d'Ohm: «More effort begets more results » (p. 274). Cette habitude appelée «causalité proportionnelle » est également citée par Stavy et Tirosh (2000) sous la forme : «More A then more B » (p. 1) : « Si la valeur de A augmente alors celle de B augmente aussi ».

Selon diSessa, les $p$-prims s'accumulent jour après jour suite aux expériences de la vie, aux interactions physiques et psychologiques avec l'environnement naturel et social. Le terme «phénoménologique» (du grec: «étude de ce qui apparaît ») découle de ce que chacun voit et retient de ses expériences quotidiennes. Le mot «primitive » est donné du fait que ces habitudes sont à l'origine des conceptions comme le génotype est à l'origine du phénotype en génétique.

Les auteurs insistent aussi sur le caractère intuitif de ces habitudes dans le sens où l'individu est incapable de les expliquer puisqu'elles lui paraissent évidentes. Les mêmes habitudes interprétatives peuvent être «bonnes» dans certains contextes et «mauvaises » dans d'autres. L'expert est censé utiliser la bonne habitude dans un certain contexte, ce que ne réalise pas toujours le novice. Le contexte a d'ailleurs dans ce modèle une influence majeure, ce qui explique le caractère incohérent des réponses des élèves pour un même concept scientifique par simple modification du contexte.
Comme pour le modèle de Vosniadou, si l'enseignant ne tient pas compte de ces habitudes intuitives, l'apprenant ne pourra pas «accommoder» à long terme les nouveaux concepts dans sa structure cognitive.

Pour diSessa, un raisonnement est toujours logique, seule(s) une (des) habitude(s) pour le mener est (sont) erronée(s). Une solution est d'analyser avec l'apprenant tous les éléments de son raisonnement en cherchant à trouver ceux qui sont à l'origine de l'erreur de façon à les réviser.

Ainsi, selon cette optique, l'élève ne raisonnerait pas en référence à un cadre théorique cohérent (« Knowledge-astheory »), mais en puisant dans une collection non structurée d'éléments simples («Knowledge-in-pieces »). De ce point de vue, le changement conceptuel résulte davantage du passage d'un savoir fragmenté à un savoir structuré (par ajout, suppression, révision des éléments qui constituent le répertoire de $p$-prims afin de développer une classe de coordination plus conforme au savoir scientifique) plutôt que d'une modification profonde de son cadre théorique de pensée.

D'autres auteurs proposent des variantes de ces modèles comme les «conceptions d'ancrage » (Clement, Brown et Zietsman, 1989), les conceptions faisant partie d'une 《structure conceptuelle» (Duit et Treagust, 2003), le concept de «facettes », selon lequel une classification des idées spontanées des apprenants est réalisée (Minstrell, 2001).

Nous ne développons pas ces modèles, dont la liste n'est d'ailleurs pas exhaustive. Les lunettes à travers lesquelles nous étudions les conceptions des apprenants dans la suite de notre texte sont celles fournies par le modèle de diSessa. Une étude diagnostique sur les difficultés d'acquisition du concept de concentration a été réalisée dans la phase qui précède celle dont traite ce présent article. Elle nous a permis de mettre en évidence le caractère intuitif des réponses données par les élèves interrogés sur le volume de solution, comme des «réflexes » mobilisés sans raisonnement structuré. Les élèves interrogés semblaient utiliser une heuristique qui leur permettait de répondre rapidement à la question sans appui sur une théorie élaborée et rigide. Une modification mineure de l'énoncé, sans conséquence sur le raisonnement à utiliser ni sur le résultat, les amenait à utiliser une heuristique parfois opposée (Willame et Snauwaert, 2015).

2.2.3 L'apport des neurosciences cognitives au modèle du changement conceptuel

L'utilisation des techniques d'imagerie fonctionnelle cérébrale a permis d'étudier les régions du cerveau qui s'activent lors de la réalisation de tâches cognitives.

Jonathan A. Fugelsang et Kevin N. Dunbar font partie des premiers chercheurs en didactique à se tourner vers l'utilisation de l'imagerie cérébrale. Ils constatent en effet la difficulté à obtenir un changement conceptuel. Ils ont voulu 
établir un lien entre le conflit cognitif et les régions du cerveau qui y sont associées. Leur approche est d'examiner le recrutement des circuits neurologiques cérébraux qui sont impliqués lorsque les individus reçoivent des données incohérentes avec leurs propres conceptions. Leurs résultats d'expériences publiées en 2005 (Fugelsang et Dunbar, 2005) montrent que lorsqu'un sujet est mis en situation de conflit cognitif, il traite l'information comme une erreur et il détourne son attention. Au final, le sujet n'assimile pas la nouvelle conception proposée. Selon Dunbar, cette expérience démontre l'une des raisons pour laquelle le changement conceptuel soit difficile à obtenir.

Plutôt que de comparer l'activité cérébrale avant et après la réalisation d'un changement conceptuel, une stratégie d'étude consiste à comparer l'activité cérébrale d'un groupe d'experts qui semblent avoir réalisé un changement conceptuel avec un groupe de novices ne l'ayant pas réalisé. C'est de cette façon que Dunbar, Fugelsang et Stein procèdent à de nouvelles expérimentations publiées en 2007. Ils constatent que les conceptions erronées sont toujours présentes même chez un expert mais que celui-ci est capable d'activer certaines zones cérébrales pour, semble-t-il, inhiber les théories naïves et donc proposer une réponse correcte :

Yet the results of the experiments reported in this chapter indicate that even when conceptual change appears to have taken place, students still have access to the old naïve theories and that these theories appear to be actively inhibited rather than reorganized and absorbed into the new theory. (Dunbar, Fugelsang et Stein, 2007, p. 202)

Steve Masson en 2012 arrive aux mêmes conclusions. Il observe que les experts possèdent toujours la trace de leurs fausses conceptions, mais qu'ils les inhibent, ce qui leur permet de résoudre scientifiquement des problèmes :

Plus précisément, notre interprétation des résultats obtenus appuie l'idée selon laquelle les experts possèderaient toujours dans leur cerveau la trace d'une conception inappropriée [...] et que, suite à leur formation scientifique, ils auraient développé une conception plus conforme aux savoirs scientifiques, mais n'auraient pas effacé de leur cerveau leur conception initiale qu'ils doivent alors inhiber. (Masson, 2012, p. 111)

Déjà en 1999, Olivier Houdé étudie le comportement de jeunes enfants et il envisage que le développement de l'intelligence ne consiste pas seulement à construire et à activer des stratégies cognitives nouvelles, comme le pensait Jean Piaget. L'enfant doit aussi apprendre à bloquer, inhiber la stratégie inadéquate. En parlant de la tâche de la conservation du nombre, Houdé explique :

Cette tâche a été reprise de façon informatisée en IRMf avec des enfants d'école maternelle et élémentaire, révélant qu'elle mobilisait non seulement les régions du cerveau dédiées au nombre (le cortex pariétal), mais aussi les régions du cortex préfrontal dédiées à l'inhibition des automatismes : ici l'automatisme selon lequel en général la longueur varie avec le nombre. Cela amène à réviser la théorie de Piaget en y ajoutant le rôle clé de l'inhibition cognitive comme mécanisme positif du développement de l'intelligence de l'enfant. (Houdé, 2016a, p. 21)

Selon Houdé, le modèle le plus adapté pour expliquer le développement cognitif semble le modèle de « vagues qui se chevauchent 》 (《 overlapping waves ») proposé par Robert S. Siegler (1996): au cours de son développement, l'enfant accumule un réservoir de stratégies où il puise celle qu'il juge la plus efficace dans le contexte où il se trouve. Houdé et son équipe traduisent ce modèle en y ajoutant une composante liée à l'inhibition. L'individu met au point et accumule des heuristiques qui lui permettent de réagir rapidement à diverses situations. Chaque stratégie ayant son propre champ d'application, l'individu est donc amené à inhiber l'une des stratégies et à en activer une autre afin de répondre au mieux à une situation donnée. Si l'inhibition n'est pas correctement effectuée, la réponse à une question impliquant une conception erronée sera erronée.

Lors du processus de contrôle inhibiteur lié au raisonnement conditionnel, Houdé et al. (2000) expliquent :

We demonstrate how a set of left-prefrontal regions recruited by the executive component of object, spatial, and verbal working memory, and a rightprefrontal region ensuring the emotionalmotivational aspects of decision making, all work together in a dynamic way to inhibit a perceptual bias and activate a deductive reasoning process. (p. 725)

Avec l'utilisation de l'imagerie cérébrale, Houdé et TzourioMazoyer (2003) montrent qu'un apprentissage à l'inhibition permet une reconfiguration des zones d'activation cérébrale qui se sont déplacées de la partie postérieure du cerveau à sa partie antérieure (au cortex préfrontal).

Le modèle de prévalence conceptuelle (Potvin, 2013 ; Potvin, Sauriol et Riopel, 2015) tente un ajustement de la théorie classique du changement conceptuel par l'apport des études en neurosciences et psychologie cognitives et il propose des conditions pour l'apprentissage en classe. Selon ce modèle, l'apprentissage ne se réalise qu'en situation de compétition entre différentes conceptions. Ainsi, il ne faut pas produire de conflit cognitif chez l'apprenant tant qu'il n'accorde pas de crédit à une autre stratégie possible. Dans un deuxième temps, lorsque l'apprenant est conscient des insuffisances de certaines conceptions dans certains contextes, il doit installer des signaux d'alerte inhibitifs («inhibitive stop signs ») pour bloquer leur utilisation. L'apprenant doit ensuite automatiser le procédé d'inhibition de la (des) conception(s) non pertinente(s) dans le contexte de la question par un 
entrainement métacognitif à l'inhibition. Dans le modèle de prévalence conceptuelle, le rôle du conflit cognitif est donc envisagé différemment :

[...] le conflit cognitif aurait d'abord et avant tout pour but de rendre explicite la conception initiale de manière à permettre qu'on développe éventuellement une bonne capacité à la reconnaître distinctement lorsqu'elle se manifeste, ainsi que celle de pouvoir choisir de refuser, consciemment, puis éventuellement de manière automatisée, de la mobiliser. (Potvin, 2011, p. 218).

Ainsi, les recherches en neurosciences ont permis de proposer un nouveau modèle : il ne s'agirait pas de changer les conceptions, autrement dit «d'effacer» ou de restructurer de façon approfondie les réseaux neuronaux en place, mais plutôt d'apprendre à « inhiber » ceux menant à la formulation de réponses inappropriées et d'activer ceux conduisant à la conception experte (Babai, Younis et Stavy, 2014 ; Brault Foisy et al., 2015 ; Houdé, 2016a ; Masson, 2012 ; Potvin, Riopel et Masson, 2007).

Plusieurs études rapportent l'importance du contrôle inhibiteur comme fonction exécutive dans l'acquisition de connaissances en mathématiques, orthographe ou lors de l'exécution de consignes (Borst, Moutier et Houdé, 2014 ; Cassotti et Moutier, 2010 ; Lubin et al., 2012 ; Rossi et al., 2012). Le sujet doit apprendre à bloquer certaines réponses intuitives erronées dans le contexte de la question pour progresser dans l'apprentissage du concept envisagé. L'élève doit s'entrainer à corriger ses erreurs à l'aide d'alertes et, pour ce faire, il manipule un dispositif tel qu'un «attrape-piège ». Rossi et al. (2012) décrivent ainsi leur attrape-piège :

Il se matérialise par une planche sur laquelle est apposé un transparent que l'enfant peut soulever et replacer à sa guise. Sur ce transparent apparaît une zone hachurée qui matérialise les processus attentionnels d'inhibition, sous laquelle l'enfant va être amené à placer la réponse erronée. Ce transparent est troué en son centre laissant apparaitre une zone d'activation attentionnelle non hachurée dans laquelle l'enfant va être amené à placer la réponse correcte. Les cartons réponses, d'autres alertes visuo-spatiales, sont colorés en rouge ou vert selon qu'ils représentent la mauvaise ou la bonne réponse. (p. 40).

Les résultats de ces études encouragent à développer l'apprentissage à l'inhibition en classe.

\section{Questions de recherche}

\subsection{Origine des questions de recherche}

Une des phases de notre recherche a consisté à comprendre l'origine de la non considération de l'augmentation de volume de la solution lorsqu'un soluté est dissout dans un solvant. Pour ce faire, une première étape a été de poser une question simple à 135 élèves de différents niveaux scolaires (tous issus du système scolaire belge francophone) : «Que fait le niveau de liquide si du sel de cuisine est ajouté puis dissout (après agitation) dans un volume d'eau? ». La question était accompagnée d'un support matériel: un tube à essais contenant de l'eau et un second avec quelques grammes de sel. Les prévisions des interrogés sont proposées dans le tableau 1.

Ainsi, 91 \% des élèves de première primaire, non experts en chimie, répondent correctement à cette question contre $37,5 \%$ des élèves de quatrième secondaire et $34,5 \%$ des futurs enseignants de sciences.

Dans une deuxième étape, des entretiens d'explicitation (Vermersch, 2011) ont permis de mettre en évidence que la plupart des enfants de 6-7 ans utilisent la stratégie «Plus de matière donc plus de volume »; stratégie que nous associons à la $p$-prim de causalité proportionnelle «More $\mathrm{A}$ then more $\mathrm{B}$ 》.

La majorité des élèves plus âgés qui ont suivi des enseignements en chimie n'utilisent plus cette stratégie pourtant efficace dans le contexte de la dissolution d'un soluté dans un solvant et donc du calcul d'une concentration chimique.

Tableau 1. Prévisions selon la classe des interrogés à la question «Que fait le niveau de liquide si du sel de cuisine est ajouté puis dissout (après agitation) dans un volume d'eau? »

\begin{tabular}{|c|c|c|c|c|}
\hline \multirow[b]{3}{*}{ Classe des interrogés } & & & & \\
\hline & \multicolumn{4}{|c|}{ Prévisions } \\
\hline & Effectif & $\begin{array}{c}\text { Le niveau reste le } \\
\text { même }\end{array}$ & $\begin{array}{l}\text { Le niveau monte } \\
\text { (réponse correcte) }\end{array}$ & Le niveau baisse \\
\hline $1^{\text {ère }}$ primaire (6-7 ans) & 36 & $3 \%$ & $91 \%$ & $6 \%$ \\
\hline $6^{\mathrm{e}}$ primaire (11-12 ans) & 30 & $40 \%$ & $47 \%$ & $13 \%$ \\
\hline $4^{\mathrm{e}}$ secondaire (15-16 ans) & 40 & $60 \%$ & $37,5 \%$ & $2,5 \%$ \\
\hline $\begin{array}{l}\text { Futurs enseignants de sciences } \\
\text { ( } 6 \text { ans d'études supérieures en sciences) }\end{array}$ & 29 & $62 \%$ & $34,5 \%$ & $3,5 \%$ \\
\hline
\end{tabular}


Les explications données par les élèves de 15-16 ans (grade 10) qui répondent de façon incorrecte que le niveau reste le même sont probablement liées à des utilisations ou interprétations erronées des modèles chimiques et de leurs représentations iconographiques. Selon de Berg (2012), la visualisation du modèle de particules de la matière, qui est déterminante pour comprendre le concept de concentration, est connue pour présenter des difficultés pour les étudiants. Selon lui, les locutions verbales associées aux modèles chimiques ne permettent pas à tous les apprenants en chimie de déclencher une image moléculaire visuelle d'où l'utilisation des représentations submicroscopiques (SMR pour 《submicroscopic representations »). Mais ces visualisations du modèle particulaire de la matière peuvent elles-mêmes poser des difficultés aux apprenants. De même, Tümay (2016) ajoute qu'une autre difficulté dans l'apprentissage de la chimie est liée à la compréhension des interactions entre les entités qui constituent la matière. Celles-ci dépendent de nombreux paramètres et les élèves ont des difficultés à considérer plusieurs données microscopiques ensemble pour comprendre les modèles proposés par les experts.

Citons quelques exemples de stratégies que les élèves interrogés ont explicitées et qui seraient à l'origine de la non considération de la place occupée par le soluté dissout :

\section{1. « car le sel se dissout ».}

Le fait de se dissoudre est une justification en soi. La dissolution permet d'obtenir un mélange homogène. Pour ces élèves, cela signifie que le soluté « disparait » et ils semblent en déduire qu'il n'existe plus. Le volume de soluté serait donc négligé et le volume de solvant est dès lors considéré comme le volume de solution. Ces élèves restent sur une vision macroscopique de la solution.

\section{2. «car le sel absorbe l'eau ».}

Cette réponse est peut-être liée à des expériences de la vie (scolaire ou non) où des poudres «pompent» des liquides sans qu'un volume supplémentaire ne paraisse occupé. Tout comme les élèves du point précédent, leur raisonnement se base sur une vision macroscopique de la matière: ils n'envisagent pas les entités de soluté comme des entités individuelles capables de réaliser des liaisons avec l'eau. Ils s'en tiennent à la matière «sel » en tant qu'« ensemble ».

3. «car les entités de sel vont combler l'espace entre les molécules d'eau ».

Pour les élèves qui utilisent cette stratégie de réponse, la vision microscopique de la solution détermine leur raisonnement puisqu'ils envisagent, à l'inverse des élèves précédents, la solution comme un ensemble d'entités bien distinctes : les molécules d'eau et les entités de soluté. Pour eux, le soluté ne disparait pas, mais il prend la place qui existe entre les molécules d'eau. Pour ces élèves, il est possible que les représentations iconographiques des molécules d'eau en forme de ronds mènent à cette conception. Cette stratégie est logique et en partie vraie puisque le volume de sel avant dissolution additionné au volume d'eau de départ est supérieur au volume de solution une fois le sel dissout dans l'eau.

Pour les futurs enseignants de sciences qui répondent majoritairement de façon incorrecte que le niveau de liquide reste le même, les explications sont extrêmement variées. Les nombreuses justifications différentes proposées par les étudiants universitaires interrogés ont toutefois un point commun : elles utilisent un langage issu de la chimie et se réfèrent à de multiples modèles chimiques. Les étudiants s'expriment en utilisant les termes «interactions entre les ions sodium et chlorure », «solvatation des ions présents », 《polarité de la molécule d'eau », « saturation de l'eau en sel », 《 réactions chimiques », «masse volumique », etc.

Deux précédentes publications développent les différentes conceptions des différents groupes d'interrogés (Willame et Snauwaert, 2016 ; Willame, 2017).

\subsection{Nos questions de recherche}

Pour utiliser correctement le concept de concentration chimique, l'apprenant doit prendre conscience que le volume de solution est supérieur au volume de solvant. Il doit activer (ou réactiver) cette $p$-prim: «Plus de matière donc plus de volume » dans le contexte de calculs de la concentration d'un soluté au sein d'une solution. Pour ce faire, des outils didactiques et neuroscientifiques utilisant le conflit cognitif et l'entrainement à la fonction exécutive de contrôle inhibiteur des conceptions non pertinentes doivent être construits, testés et confrontés. Notre objectif est d'améliorer les scores obtenus par les élèves interrogés dans ce contexte.

Trois questions de recherche ont été posées :

- Les scores des apprenants sont-ils améliorés après un conflit cognitif?

- Les scores des apprenants sont-ils améliorés si le conflit cognitif est suivi d'un entrainement à l'inhibition des conceptions non pertinentes?

- Quel que soit le type de question posée à un apprenant, l'entrainement à l'inhibition a-t-il le même effet sur la réponse finale?

\section{Méthodologie}

\subsection{Participants}

Notre étude a été réalisée dans deux écoles de Belgique francophone entre mars 2015 et mars 2016. Huit classes de grade 10 (élèves entre 15 et 17 ans) ont participé à la recherche pour un total de 150 élèves. Tous les élèves étaient issus de classes mixtes ayant un cours de 5 heures par semaine en sciences (classes dites « en option sciences ») dont 2 heures de chimie. Ils avaient tous suivi, dans l'année, l'apprentissage du concept de concentration chimique. 
Quatre classes ont suivi l'activité impliquant un conflit cognitif seul soient 72 élèves (groupe CC pour «Conflit Cognitif ») et quatre classes ont suivi l'activité impliquant un conflit cognitif suivi d'un entrainement à la fonction exécutive de contrôle inhibiteur des conceptions non pertinentes soient 78 élèves (groupe $\mathrm{CC}+\mathrm{EI}$ pour «Conflit Cognitif » et « Entrainement à l'Inhibition »).

\subsection{Chronologie de l'expérimentation et conditions de passation}

Chaque élève a été soumis à un pré-test comprenant quatre questions à propositions multiples et choix unique (annexe 1). Pour répondre correctement à ces questions sur la concentration chimique, l'interrogé doit avoir pris conscience que le volume de solution est supérieur au volume de solvant et que pour calculer une concentration, le volume de solution doit être utilisé. Chaque groupe a ensuite été soumis à une activité : le groupe $\mathrm{CC}$ a été soumis à une activité impliquant un conflit cognitif et le groupe CC+EI a été soumis à une activité impliquant un conflit cognitif suivi d'un entrainement à linhibition des conceptions non pertinentes dans le contexte de la concentration chimique. Chaque élève a ensuite répondu à un post-test (quatre questions similaires à celles du pré-test). Le post-test a été proposé juste après l'activité.

Ces activités se veulent utilisables en situation de classes réelles et leur durée de réalisation ne dépasse pas une période de cours soit 50 minutes. Chacune des étapes de l'expérimentation était décrite sur des feuilles séparées et fournies au fur et à mesure que l'élève avait fini une étape. L'élève était seul pour répondre aux différentes étapes sans possibilité de communiquer avec ses pairs.

\subsection{Outil visant le conflit cognitif}

Lors de la phase diagnostique, notre recherche a montré que de nombreux élèves considèrent le volume de solvant et non de solution pour le calcul de la concentration en soluté. Les entretiens d'explicitation ont mis en évidence que ces apprenants n'envisagent pas la place supplémentaire occupée par le soluté. L'activité construite (annexe 2) s'appuie sur ces résultats. Elle fait appel à une manipulation simple: deux tubes à essais sont présentés à l'élève. Le premier contient 20 millilitres d'eau (niveau d'eau marqué par un trait sur le tube) et le second contient 3 grammes de sel de cuisine (chlorure de sodium). Il est demandé à l'apprenant de prévoir ce que va devenir le niveau de solution suite à la dissolution du sel dans l'eau. L'élève réalise ensuite la manipulation et confronte sa prévision à son observation. Le niveau de liquide augmente de façon très visible (élévation du niveau de liquide dans le tube de $0,5 \mathrm{~cm}$ ). Si l'élève observe une différence, un conflit perceptivo-cognitif devrait se réaliser.

Suite à cette activité, afin d'institutionnaliser l'importance du volume de solution dans le calcul d'une concentration, un texte est donné à chaque élève. Il lui est rappelé que :

1. le volume de solution est supérieur au volume de solvant ;
2. pour calculer la concentration d'un soluté, il faut considérer le volume de solution et pas celui de solvant ;

3. si le volume total de la solution n'est pas connu, il est impossible de calculer la concentration du soluté.

4.4 Outil visant l'entrainement à la fonction exécutive de contrôle inhibiteur des conceptions non pertinentes

L'activité doit permettre de réactiver la prévalence d'une habitude intuitive que la plupart des apprenants utilisent spontanément lorsqu'ils sont encore en première primaire à savoir « More A then more B ». Elle n'est plus prévalente dans le contexte de la dissolution d'un sel dans l'eau au fur et à mesure que les apprenants approfondissent les modèles chimiques utilisant les représentations symboliques des constituants de la matière et de leurs interactions (tableau 1).

L'activité amenant l'élève à s'entrainer à inhiber les conceptions non pertinentes dans le contexte de la dissolution d'un soluté dans un solvant et du calcul d'une concentration chimique consiste, dans un premier temps, à faire prendre conscience à l'apprenant de la compétition entre deux conceptions :

- Conception «Vsolution» (pertinente dans les contextes de la dissolution d'un soluté dans un solvant et du calcul d'une concentration chimique) : «Après dissolution d'un soluté dans un solvant, le volume de solution est supérieur au volume de solvant »,

- Conception «Vsolvant» (non pertinente dans les mêmes contextes) : «Après dissolution d'un soluté dans un solvant, le volume de solution est égal ou inférieur au volume de solvant ».

L'élève est alors invité à activer celle pertinente dans le contexte du calcul d'une concentration (conception «Vsolution») et mis en garde de ne pas employer la conception non adéquate (conception «Vsolvant »).

Dans un deuxième temps, l'élève de grade 10 est amené à automatiser l'activation de la conception pertinente «Vsolution » et l'inhibition de la conception non pertinente «Vsolvant ». Nous avions opté pour un dispositif d'« attrapepiège » fait d'un cache avec fenêtre, d'un carton rouge (conception à inhiber: «Je calcule la concentration en utilisant le volume de solvant») et d'un carton vert (conception à activer: «Je calcule la concentration en utilisant le volume de solution ») de Rossi et al. (2012). Suite aux premiers essais, nous avons constaté que les adolescents de grade 10 interrogés ne suivaient pas la consigne de répéter l'opération pour chacune des questions posées. L'automatisation du processus d'inhibition n'a donc pas été réalisée. Cette constatation a également été faite avec des élèves de grade 9 lors d'un master en sciences de l'éducation (Van Lerberghe, 2017).

Nous avons préféré construire un autre dispositif qui conviendrait davantage à l'âge des élèves ciblés par notre étude (adolescents de 16-17 ans) dont l'utilisation serait 
inévitable à chaque question posée et où l'élève en remédiation pourrait être lui-même un « attrape-piège ».

L'élève de grade 10 est invité à vérifier la copie d'un élève de grade 9, prénommé Alex, qui a écrit cinq affirmations en lien avec le volume considéré dans le calcul d'une concentration. L'élève de grade 10 en activité doit contrôler, pour chaque phrase écrite par Alex, que celui-ci a bien activé la conception pertinente «Vsolution » pour le calcul d'une concentration et inhibé la conception non pertinente «Vsolvant». De cette façon, l'adolescent de grade 10 est responsabilisé à vérifier que l'un de ses pairs progresse correctement dans son apprentissage.

La figure 2 donne une partie du tableau que l'élève en activité doit compléter (tableau complet en annexe 3).

Les trois premières des cinq phrases sont suivies d'une correction. Les première et troisième phrases sont erronées ; le volume considéré n'est pas celui de la solution mais celui du solvant. Il ne faut pas que l'élève en remédiation commette lui aussi les mêmes erreurs qu'Alex et il doit donc vérifier que l'examen qu'il fait des phrases d'Alex est correct. Si l'élève en activité a mal corrigé Alex, il est mis en garde pour la suite : «Si tu as mal corrigé Alex, reste vigilant pour la suite : active bien la conception : la concentration se ramène au volume de solution. ».

\begin{tabular}{|l|l|l|}
\hline \multicolumn{1}{|c|}{ Phrases écrites par Alex } & $\begin{array}{c}\text { Activation de } \\
\text { Vsolution } \\
\text { Bien! }\end{array}$ & $\begin{array}{c}\text { Non activation de } \\
\text { Vsolution } \\
\text { Pas bien! }\end{array}$ \\
\hline $\begin{array}{l}\text { 1. La concentration en sel est le } \\
\text { rapport entre la quantité de sel et le } \\
\text { volume d'eau. }\end{array}$ & & \\
\hline $\begin{array}{l}\text { 2. Si je mets du sucre dans de l'eau, } \\
\text { je calcule la concentration en sucre } \\
\text { en divisant la quantité de sucre par } \\
\text { le volume d'eau sucrée. }\end{array}$ & & \\
\hline $\begin{array}{l}\text { 3. Pour préparer 1 litre d'une } \\
\text { solution de sel dont la concentration } \\
\text { sera 120 g/L, je dois mettre 1 litre } \\
\text { d'eau dans une fiole de 1 litre puis } \\
\text { rajouter 120 g de sel. }\end{array}$ & & \\
\hline
\end{tabular}

Figure 2. Partie du tableau que l'élève de grade 10 doit compléter lors de l'activité d'entrainement à l'inhibition de la conception non pertinente «Vsolvant »

Puis il poursuit avec les deux dernières phrases où la quatrième est erronée (une correction suit également ces deux phrases).

Nous avons donné un prénom à cet élève imaginaire (Alex) et associé une photo d'un jeune en âge d'être en grade 9 dans le but de motiver et d'impliquer davantage l'élève en remédiation. Le prénom «Alex » a été choisi, car il est court et il correspond à un prénom raccourci donné par les amis à une personne qui leur est proche. Ceci pour renforcer l'affectivité.
Nous nous basons sur les études des équipes de Damasio (1994), Smith et Lazarus (1990) et Houdé et al. (2001) qui ont mis en évidence que les émotions jouent un rôle biologique dans le raisonnement et la prise de décision. Smith et Lazarus précisent que l'émotion dépend d'une combinaison entre motivation, intérêt et environnement, induisant l'individualisation de la décision. Nous pensons donc que notre outil faisant appel à l'émotion devrait permettre un apprentissage optimisé.

\subsection{Analyses des données}

Les résultats des pré- et post-tests permettent d'établir des scores en fonction du nombre de réponses correctes. Nous appelons «gain conceptuel », la variation des scores entre les pré- et post-tests.

Les résultats sont analysés selon deux aspects: le gain conceptuel par élève et le gain conceptuel par question.

Gain conceptuel par élève : pour chaque élève ayant répondu aux 4 questions des pré- et post-tests, un gain conceptuel, compris entre -4 et +4 a été calculé $:$ un gain de +4 correspond à 4 réponses incorrectes au pré-test qui deviennent toutes correctes au post-test. Un 《gain 》 de -4 correspond à 4 réponses correctes au pré-test qui deviennent toutes incorrectes au post-test. Une valeur intermédiaire telle que +2 est calculée si l'élève qui répondait correctement à une question au pré-test répond correctement à trois questions au post-test. Une moyenne du gain pour l'ensemble des élèves a ensuite été calculée.

Gain conceptuel par question: pour chacune des quatre questions des pré- et post-tests et pour l'ensemble des élèves, la fréquence de réponses erronées avant l'activité qui deviennent correctes après l'activité a été calculée. Le gain conceptuel par question correspond à cette fréquence en pourcentage.

Une analyse statistique a permis de déterminer si les gains sont significatifs: distribution $t$ de Student pour le gain conceptuel par élève et distribution $\chi^{2}$ de Pearson pour le gain conceptuel par question.

\section{Résultats}

\subsection{Les conflits cognitifs apparents réalisés}

L'outil visant le conflit cognitif consiste à demander à lélève de prévoir ce que fera le niveau de liquide après l'ajout d'une quantité visible de sel dans un tube à essais contenant de l'eau, dont le niveau est marqué par un trait. Lorsque le niveau prévu par l'élève avant la manipulation est différent de ce qu'il observe après avoir réalisé la manipulation (prévision incorrecte), un conflit percepto-cognitif doit avoir lieu.

Sur base des explications de l'élève, écrites avant et après la manipulation, nous avons déterminé si un conflit cognitif 
apparent a eu lieu ${ }^{2}$. Nous préférons ajouter le terme «apparent », car nous ne pouvons pas nous placer dans la tête de l'apprenant. Nous déduisons un éventuel conflit cognitif uniquement sur la base de ce que l'élève écrit.

Nous donnons la dénomination :

« Conflit cognitif positif » («CC+ ») si l'explication de l'élève est en adéquation avec une conception experte. Nous avons attribué un CC+ aux explications où l'apprenant admet que « le sel prend de la place » ou s'il admet que «plus de matière amène plus de volume » (utilisation pertinente de la $p$-prim «More A then more B »).

Par exemple, un élève écrit « Les molécules de sel prennent de la place donc le niveau de la solution augmente » : il se rend compte que le niveau monte et justifie correctement que le sel prend de la place. Sa conception semble avoir évolué vers une conception plus experte et nous lui attribuons un conflit cognitif positif.

« Conflit cognitif négatif » («CC-») si l'explication de l'élève n'est pas en adéquation avec une conception experte.
Par exemple, un élève trouve une explication à l'augmentation du niveau de liquide en écrivant «Je pense que le liquide monte car le sel était en trop grande quantité et n'a pu se dissoudre dans l'eau ». Cet élève ne semble pas concevoir que le sel dissout occupe de la place.

«Conflit cognitif non explicite » («CC? ») si l'explication de l'élève ne permet pas de déduire si le conflit cognitif est positif ou négatif.

Un élève écrit: «Le sel s'est dissout mais a augmenté le niveau de l'eau. Je ne sais pas comment. » Il se rend compte que le niveau monte mais ne trouve pas d'explication. Un conflit cognitif a sans doute eu lieu, mais a-t-il permis le changement de prévalence, même momentané, de sa conception initiale? Nous n'en sommes pas sûrs d'où l'attribution d'un conflit cognitif non explicite.

Le tableau 2 présente, pour l'ensemble des deux groupes ayant réalisé l'activité impliquant un conflit cognitif $(n=150)$, le nombre et la fréquence de prévisions incorrectes ainsi que le nombre de conflits cognitifs (CC) positifs, négatifs et non explicites.

Tableau 2. Prévisions incorrectes et conflits cognitifs pour l'activité visant le conflit cognitif

\begin{tabular}{lccc}
\hline$n=150$ & \multicolumn{2}{c}{ Le niveau reste le même } & Le niveau diminue \\
\hline Nombre de prévisions incorrectes & $64 / 150$ & $43 \%$ & $2 / 150$ \\
Nombre de CC positifs (CC+) & $46 / 64$ & $72 \%$ & $1,5 \%$ \\
Nombre de CC négatifs (CC-) & $7 / 64$ & $11 \%$ & - \\
Nombre de CC non explicites (CC ?) & $11 / 64$ & $17 \%$ & - \\
\hline
\end{tabular}

\subsection{Gain par élève}

Sur base des quatre questions des pré- et post-tests, une moyenne du gain conceptuel pour l'ensemble du groupe a été calculée et indiquée dans le tableau 3 (un interrogé du groupe $\mathrm{CC}+\mathrm{EI}$ n'a pas répondu à deux questions au post-test; la moyenne du gain a été calculée pour un effectif de 77).

Pour le groupe $\mathrm{CC}$ soumis uniquement à un conflit cognitif, le gain conceptuel est de $+0,64$ (écart-type $=1,23$ ). L'augmentation des scores est statistiquement significative ; $t(71)=4,45, p<0,0001$.

Dans le groupe CC+EI soumis à un conflit cognitif suivi d'un entrainement à l'inhibition, le gain conceptuel $(\mathrm{M}=+1,65$, écart-type $=1,16)$ est significativement plus important que pour le groupe $\mathrm{CC} \quad(\mathrm{M}=+0,64$, écarttype $=1,23) ; t(76)=5,2, p<0,0001, d=0,85$.
Tableau 3. Confrontation des moyennes du gain conceptuel par élève pour les groupes $\mathrm{CC}$ et $\mathrm{CC}+\mathrm{EI}$

\begin{tabular}{cc}
\hline & Activité avec conflit \\
Activité & cognitif et entrainement \\
avec conflit & à l'inhibition des \\
cognitif seul & $\begin{array}{c}\text { conceptions non } \\
\text { pertinentes }\end{array}$ \\
&
\end{tabular}

\begin{tabular}{lcc} 
Groupe d'élèves & CC & CC+EI \\
Effectif $n$ & 72 & 77 \\
$\begin{array}{l}\text { Moyenne du gain } \\
\text { conceptuel par élève } \\
\text { (entre - } 4 \text { et }+4)\end{array}$ & $+0,64$ & $+1,65$ \\
$\begin{array}{l}\text { Ecart type } \\
d \text { de Cohen }\end{array}$ & 1,23 & 1,16 \\
& & 0,85 (effet fort) \\
\hline
\end{tabular}

${ }^{2}$ Les élèves ayant prévu correctement le niveau de liquide ne devaient pas expliciter leur conception après la manipulation. 
Ajoutons que 14 des 72 élèves du groupe CC ont un gain négatif (12 élèves répondent moins bien à une question après le posttest et 2 élèves à deux questions) alors qu'un seul élève des 77 du groupe $\mathrm{CC}+\mathrm{EI}$ obtient un gain négatif de -1 : cet élève avait 3 réponses erronées au pré-test et donne une réponse erronée supplémentaire au post-test (question $1 \mathrm{du}$ test).

Nous devons cependant rester prudents quant aux résultats. Une part de l'augmentation des scores est peut-être due à la durée supplémentaire que les élèves ont consacrée à la correction des affirmations d'Alex, soit environ 5 à 10 minutes selon les élèves, ainsi qu'à la pratique qu'ils en ont eue.

\subsection{Gain par question}

Nous appelons gain conceptuel par question, la fréquence en pourcentage des réponses erronées avant l'activité qui deviennent correctes après l'activité. Ainsi à la question 1 pour le groupe $\mathrm{CC}(n=72)$, nous obtenons 34 réponses erronées avant l'activité dont 25 deviennent correctes après l'activité, soit un gain conceptuel de 73,5\%.

Les résultats obtenus pour chacune des quatre questions et pour les deux groupes CC $(n=72)$ et CC+EI $(n=78)$ sont présentés dans le tableau 4.

Le graphique 1 permet de visualiser les différences de gain conceptuel par question en fonction des activités $\mathrm{CC}$ et CC+EI. Le groupe ayant suivi l'activité avec conflit cognitif et entrainement à l'inhibition obtient un gain conceptuel significativement supérieur uniquement pour les questions Q3 et Q4, par rapport au groupe ayant suivi l'activité avec conflit cognitif seul.

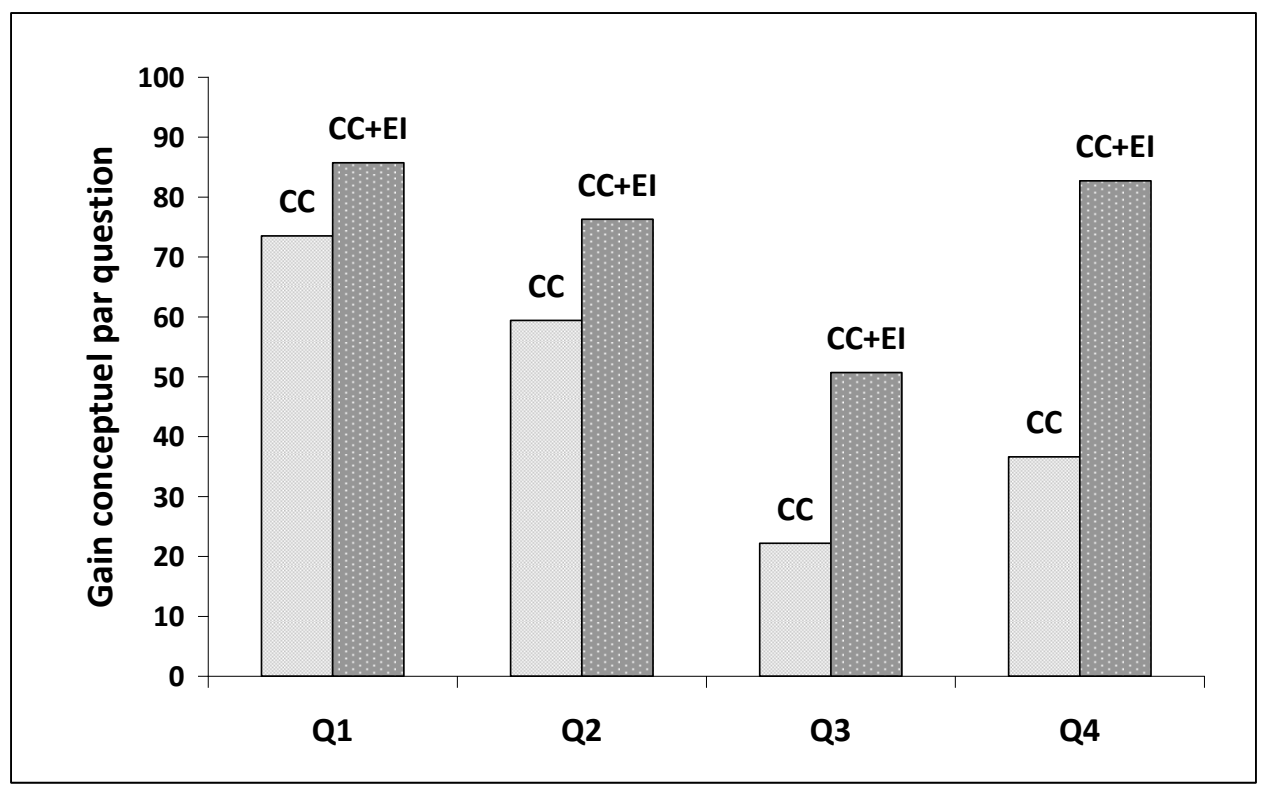

Graphique 1. Confrontation des gains conceptuels par question pour les activités CC et CC+EI

Tableau 4. Fréquence des réponses erronées avant l'activité, fréquence des réponses qui deviennent correctes après l'activité, gain conceptuel par question et tests statistiques selon la distribution de Pearson

\begin{tabular}{|c|c|c|c|c|c|c|c|c|}
\hline \multirow[t]{2}{*}{ Questions } & \multicolumn{2}{|c|}{$\begin{array}{l}\text { Fréquence des réponses } \\
\text { erronées avant l'activité }\end{array}$} & \multicolumn{2}{|c|}{$\begin{array}{l}\text { Fréquence des réponses } \\
\text { correctes après l'activité }\end{array}$} & \multicolumn{2}{|c|}{$\begin{array}{c}\text { Gain conceptuel par } \\
\text { question }\end{array}$} & \multicolumn{2}{|c|}{ Tests statistiques } \\
\hline & $\mathrm{CC}$ & $\mathrm{CC}+\mathrm{EI}$ & $\mathrm{CC}$ & $\mathrm{CC}+\mathrm{EI}$ & $\mathrm{CC}$ & $\mathrm{CC}+\mathrm{EI}$ & $\chi^{2}$ & $p$ \\
\hline Q1 & $34 / 72$ & $40 / 78$ & $25 / 34$ & $35 / 40$ & $73,5 \%$ & $85,7 \%$ & 2,34 & 0,13 \\
\hline Q2 & $32 / 72$ & $38 / 78$ & $19 / 32$ & $29 / 38$ & $59,4 \%$ & $76,3 \%$ & 2,30 & 0,13 \\
\hline Q3 & $63 / 72$ & $69 / 78$ & $14 / 63$ & $35 / 69$ & $22,2 \%$ & $50,7 \%$ & 11,51 & 0,0007 \\
\hline Q4 & $41 / 72$ & $52 / 78$ & $15 / 41$ & $43 / 52$ & $36,6 \%$ & $82,7 \%$ & 20,77 & $<0,0001$ \\
\hline
\end{tabular}




\section{Discussion}

Pour améliorer les scores des apprenants de grade 10 qui répondent à des questions sur la concentration chimique, notre méthodologie a été d'utiliser le conflit perceptocognitif associé ou non à une approche métacognitive centrée sur le contrôle inhibiteur des conceptions non pertinentes.

\subsection{Les conflits cognitifs apparents réalisés}

Une petite moitié des élèves interrogés (44\%) ne prévoient pas l'augmentation du niveau de liquide après l'ajout du chlorure de sodium dans l'eau. Suite à l'activité visant un éventuel conflit cognitif, deux-tiers d'entre eux justifient correctement que le niveau monte. Deux stratégies sont mises en évidence: $47 \%$ des élèves expliquent que «les entités de sel prennent de la place donc le volume augmente » et $53 \%$ déclarent que «plus de matière entraine plus de volume ». Nous attribuons ce changement d'expression à la réutilisation de la $p$-prim «More A then more B ». Nous utilisons le terme « réutilisation » puisque lors du test initial à la remédiation, nous avons mis en évidence que la presque totalité des élèves de première primaire utilisent cette habitude spontanée et prévoient correctement l'augmentation du niveau de liquide suite à la dissolution du sel de cuisine dans l'eau.

Nous avons cherché à vérifier si un lien existe entre la stratégie acquise après l'activité de remédiation et celle que l'élève utilisait dans sa prévision, avant l'activité. Les élèves qui prévoyaient avant l'activité que le niveau ne monterait pas, car « les entités de sel s'intercalent entre les molécules d'eau » en ayant donc une vision microscopique de la matière conservent cette vision puisque 80 \% d'entre eux déclarent après l'activité que « les entités de sel prennent de la place ». D'autres élèves expriment une vision davantage macroscopique de la matière en déclarant que le niveau ne monte pas, car « le sel disparaît » ou « le sel absorbe l'eau » ou encore, selon Lavoisier, « Rien ne se perd, rien ne se gagne, tout se transforme ». Après l'activité, la plupart d'entre eux (entre 77 et $100 \%$ selon la conception de départ) admettent que le niveau monte, car «plus de matière entraine plus de volume ». Ils restent donc sur une échelle macroscopique de la matière.

Si l'on se place du point de vue du modèle de prévalence conceptuelle de Patrice Potvin (2013), un changement de prévalence semble se réaliser suite au conflit cognitif et des « liens cognitifs » privilégiés semblent exister. Une hypothèse est que les élèves qui utilisent avant l'activité une conception plus intuitive, sans référence aux modèles microscopiques de la matière (« le sel disparaît », « le sel absorbe l'eau » ou « rien ne se perd, rien ne se gagne, tout se transforme »), rendent prévalente une conception tout aussi intuitive liée directement à une p-prim ("plus de matière donc plus de volume ») et qui reste sur une vision macroscopique de la matière. Ceux qui prévoyaient que le niveau de liquide ne monte pas, en se référant à une conception impliquant davantage une visualisation microscopique de la matière
(« les entités de sel s'intercalent entre les molécules d'eau ») telle que mise en apprentissage en chimie, rendent prévalente une conception selon laquelle cette vision reste présente tout en y intégrant l'utilisation de la $p$-prim « More A then more $B$ » (« les entités de sel prennent de la place donc le volume augmente »).

\subsection{Le gain conceptuel par élève}

L'analyse des résultats montre qu'une augmentation des scores est statistiquement significative pour les élèves ayant été confrontés au conflit cognitif. La moyenne du gain conceptuel par élève pour quatre questions est de $+0,64$ dans le cas du groupe $\mathrm{CC}$; ce résultat est interprété comme le fait que deux élèves sur trois répondent correctement à une question supplémentaire sur les quatre questions après l'activité impliquant le conflit percepto-cognitif. Le conflit percepto-cognitif leur permet d'acquérir que le soluté prend de la place au sein de la solution et ainsi de concevoir que le volume de solution est supérieur au volume de solvant. Le calcul de la concentration impliquant la division par le volume total, la conception pertinente « J'utilise le volume de solution pour calculer une concentration » est donc davantage mobilisée par les apprenants.

L'ajout au conflit cognitif d'un entrainement à la fonction exécutive de contrôle inhibiteur permet d'améliorer davantage les scores. Le gain conceptuel moyen pour le groupe ayant été soumis au conflit cognitif puis à un entrainement à l'inhibition $(+1,65$ pour 4 questions) montre qu'en moyenne chaque élève répond correctement à une question supplémentaire sur quatre par rapport aux élèves du groupe conflit cognitif seul.

Cette étape supplémentaire d'automatisation à l'inhibition de la conception non pertinente permet également de réduire fortement le nombre d'élèves qui répondent moins bien au post-test: 1 élève du groupe CC+EI au lieu de 14 pour le groupe $\mathrm{CC}$ obtient un «gain» de -1 . L'objectif étant de permettre une amélioration de l'acquisition du concept de concentration pour l'ensemble des élèves, l'entrainement à l'inhibition va davantage dans ce sens.

L'acquisition du concept de concentration chimique est favorisée par un apprentissage à l'inhibition de la conception non pertinente «Vsolvant». L'activation de la conception pertinente «Vsolution » semble permettre une réactivation de la p-prim «More A then more B »dans le contexte de la dissolution d'un soluté dans un solvant.

La remédiation avec l'entrainement à l'inhibition permet de mettre l'élève au niveau métacognitif et de lui faire prendre conscience qu'il doit contrôler ses habitudes en fonction du contexte. La remédiation crée en quelque sorte, une rationalisation de la pensée intuitive. L'élève est mis en garde que des conceptions sont en compétition lorsqu'il raisonne sur un concept et qu'il doit rester maitre de la conception à utiliser de façon à la rendre prévalente dans ce 
contexte : l'apprenant est mis en conscience qu'il doit gérer les fonctions exécutives qui l'amènent à raisonner.

Cette approche est positive puisque les différentes $p$-prims et les conceptions qui en résultent ne sont pas en ellesmêmes erronées, mais c'est leur activation qui peut l'être dans certains contextes.

La répétition de cette mise en garde de l'existence d'un piège permet d'automatiser le nouveau « lien cognitif » qui aboutit à activer la conception prévalente dans le contexte de la question.

\subsection{Le gain conceptuel par question}

L'analyse des résultats montre que l'entrainement à l'inhibition permet une augmentation statistiquement significative pour les questions Q3 et Q4 des pré- et posttests. Ces deux questions demandent une mobilisation cognitive plus importante que les questions Q1 et Q2 qui se réfèrent aux définitions de la concentration chimique. Elles ne demandent pas une réflexion avancée alors que les questions Q3 et Q4 sont davantage de l'ordre du savoir-faire.

La question Q3 avait été posée dans une précédente étude diagnostique (Willame et Snauwaert, 2015) : «Une solution est préparée en dissolvant $100 \mathrm{~g}$ de chlorure de sodium $\mathrm{NaCl}$ dans $500 \mathrm{~mL}$ d'eau. Quelle est la concentration massique en $\mathrm{NaCl}$ obtenue? ». La grande majorité $(90 \%)$ des élèves interrogés répondaient de façon erronée que la concentration massique est de $200 \mathrm{~g} / \mathrm{L}$ (la réponse correcte est «Il manque des informations pour répondre » puisque seul le volume de solvant est donné). Les résultats dans cette présente étude confirment ces chiffres (132 élèves sur les 150 ne répondent pas correctement avant les activités). Nous avions suggéré que les interrogés appliquent le contrat didactique implicite en sciences «Des valeurs numériques dans un énoncé impliquent un calcul numérique dans la réponse ». Les résultats présentés dans cet article montrent que le conflit cognitif seul a permis à un élève sur quatre de répondre correctement à cette même question alors que le conflit cognitif associé au contrôle inhibiteur permet de doubler cette fréquence puisqu'un élève sur deux répond alors correctement. Le contrat didactique reste cependant appliqué par de nombreux élèves.

La question Q4 s'intéresse à la façon de préparer une solution. Le fait que le soluté prenne de la place au sein de la solution implique au chimiste d'ajouter le soluté avant de compléter son volume au volume désiré de solution. Le conflit cognitif permet à un peu plus d'un tiers des interrogés de répondre correctement, mais le contrôle inhibiteur fait évoluer ce résultat à plus de 8 élèves interrogés sur 10 . Le fait de se rendre compte, grâce à la manipulation, que le niveau de liquide augmente n'est pas suffisant pour la majorité des élèves à rendre prévalente la conception pertinente 《Vsolution ». C'est l'inhibition de la conception «Vsolvant » et l'automatisation de l'activation de la conception «Vsolution» qui permet de rendre cette conception pertinente prévalente dans le contexte de la préparation d'une solution de concentration connue.

Dans le contexte de la dissolution d'un soluté et du calcul de sa concentration au sein de la solution, nos résultats montrent l'intérêt du conflit cognitif suivi d'un entrainement à l'inhibition des conceptions non pertinentes. La fonction exécutive telle que le contrôle inhibiteur semble jouer un rôle important dans le parcours scolaire des apprenants en sciences.

Sur base du test diagnostique réalisé dans les classes de différents niveaux (de la primaire aux futurs enseignants de sciences; tableau 1), les activités proposées aux apprenants dans le cadre de cette étude permettraient une réactivation d'une habitude délaissée dans le cadre de la dissolution d'un soluté chez les plus experts en chimie : "More A then more $B$ ». Cette $p$-prim n'est pas pertinente dans tous les contextes scientifiques. Ainsi, dans le contexte de la chute des corps, cette habitude de causalité proportionnelle est celle à inhiber puisque ce n'est pas parce que la masse d'un objet est plus grande que sa vitesse de chute augmente (Brault Foisy et al., 2015 ; Dunbar et al., 2007). De même, en mathématiques, cette même habitude est également celle à inhiber dans le cas, par exemple, de la comparaison de l'aire et du périmètre de différentes figures géométriques. En effet, ce n'est pas parce qu'une surface est plus petite ou plus grande que le périmètre est proportionnellement plus petit ou plus grand (Babai et al., 2009).

La reconnaissance du contexte dans lequel le sujet doit apprendre à bloquer certaines réponses intuitives erronées est donc essentielle. Il s'agit donc d'entrainer l'apprenant dans un premier temps à reconnaître le contexte de l'apprentissage ou de la question puis, dans un second temps, à contrôler ses réponses intuitives.

\section{Conclusion et propositions pour l'enseignement}

Notre étude montre que l'apprentissage d'un concept passe aussi par un contrôle de ses intuitions, de ses habitudes intuitives pour rationaliser sa pensée. L'enseignant qui est au cœur de l'apprentissage de ses élèves a donc un rôle majeur à jouer. Il doit être celui qui participe à la prise de conscience que chacun a emmagasiné des conceptions utiles, mais qui doivent être mobilisées de façon pertinente en fonction du contexte. Il s'agit de rendre prévalente celle qui permettra d'envisager le concept de façon experte.

Pour remédier aux difficultés d'apprentissage d'un concept, le conflit cognitif qui précède l'entrainement au contrôle inhibiteur joue un rôle essentiel. L'élève en difficulté n'envisage pas la conception pertinente comme celle à rendre prévalente du fait qu'il accorde un statut trop important aux conceptions non appropriées. Le conflit lui fait prendre conscience qu'il doit modifier ce statut. Le conflit cognitif n'est pas vécu comme une arme qui attaque l'intelligence de l'individu, mais comme une lampe qui éclaire la conception à rendre prévalente. 
L'élève doit ensuite s'entrainer à allumer cette lampe tout en laissant dans l'obscurité les conceptions non adéquates dans le contexte considéré. Il devra les éclairer en fonction du contexte. Cette étape d'entrainement à l'inhibition des conceptions non pertinentes est donc fondamentale pour automatiser l'éclairage, l'activation de la conception appropriée dans le bon contexte. Les outils tels que les alertes émotives (ou «inhibitive stop signs 》) sont les signaux déclencheurs d'un contrôle de ses intuitions afin d'« attraper le piège » et mobiliser ainsi la conception pertinente. L'automatisation de ce processus permettra de changer, non pas de conception, mais de prévalence conceptuelle.

Une récente étude de Potvin et Cyr (2017), menée sur le thème de la flottabilité de boules de masse, volume et matière différentes, suggère que l'enseignement a permis de rendre prévalente les conceptions scientifiques des experts. Notre étude montre que l'enseignement peut, à l'inverse, rendre prévalentes des conceptions non appropriées. L'enseignant doit en être conscient. Il doit rester lui-même vigilant quant aux conceptions qui interfèrent et dont le statut peut être renforcé suite à la mise en apprentissage des modèles scientifiques. Cela s'avèrerait d'autant plus en chimie, où les représentations symboliques du niveau microscopique d'une matière visible macroscopiquement peuvent conduire à créer des interférences supplémentaires dont le statut trop important empêche de rendre prévalente la conception experte pour le contexte considéré.

Nous n'avons pas mesuré à long terme l'impact d'une remédiation impliquant un conflit cognitif et un apprentissage à l'inhibition de la conception non pertinente, mais il semble qu'une étape de renforcement soit nécessaire pour rendre durable la prévalence conceptuelle (Potvin et Cyr, 2017). Ce renforcement peut se faire par des retours réguliers pendant l'année sur les alertes mises en place, pendant les remédiations.

Cette étude montre que les recherches en didactique («montrer le chemin») et en sciences cognitives («comprendre le chemin») peuvent contribuer à l'amélioration de l'apprentissage en classe. La collaboration entre les chercheurs et les enseignants est essentielle pour que les outils puissent être intégrés dans les cursus scolaires.

\section{Références}

Arnaud, P. (1989). Cours de chimie physique (3 éd.). Paris, France : Dunod.

Astolfi, J.-P. (1992). Apprendre par franchissement d'obstacles? Repères, 5(1), 103-116. https://doi.org/10.3406/reper.1992.2052

Astolfi, J.-P., Darot, E., Ginsburger-Vogel, Y. et Toussaint, J. (2008). Mots-clés de la didactique des sciences ( $2^{\mathrm{e}}$ éd.). Bruxelles, Belgique : De Boeck. https://doi.org/10.3917/dbu.astol.2008.01
Babai, R., Younis, N. et Stavy, R. (2014). Involvement of inhibitory control mechanisms in overcoming intuitive interferences. Neuroeducation, 3(1), 1-9. https://doi.org/10.24046/neuroed.20140301.1

Babai, R., Zilber, H., Stavy, R. et Tirosh, D. (2009). The effect of intervention on accuracy of students' responses and reaction times to geometry problems. International Journal of Science and Mathematics Education, 8(1), 185201. https://doi.org/10.1007/s10763-009-9169-8

Borst, G., Moutier, S. et Houdé, O. (2014). Negative priming in logicomathematical reasoning: the cost of blocking your intuition. Dans W. De Neys et M. Osman (dir.), New approaches in reasoning research - Current issues in Thinking \& Reasoning (p. 34-50). New York, NY: Psychology Press.

Brault Foisy, L.-M., Potvin, P., Riopel, M. et Masson, S. (2015). Is inhibition involved in overcoming a common physics misconception in mechanics? Trends in Neuroscience and Education, 4(1-2), 26-36. https://doi.org/10.1016/j.tine.2015.03.001

Brown, D. E. (1993). Refocusing core intuitions: A concretizing role for analogy in conceptual change. Journal of Research in Science Teaching, 30(10), 1273-1290. https://doi.org/10.1002/tea.3660301009

Cassotti, M. et Moutier, S. (2010). How to explain receptivity to conjunction-fallacy inhibition training: Evidence from the Iowa Gambling Task. Brain and Cognition, 72(3), 378384. https://doi.org/10.1016/j.bandc.2009.11.004

Clement, J., Brown, D. E. et Zietsman, A. (1989). Not all preconceptions are misconceptions: finding "anchoring conceptions" for grounding instruction on students' intuitions. International Journal of Science Education, 11(5), 554-565. https://doi.org/10.1080/0950069890110507

de Berg, K. (2012). A study of first-year chemistry student' understanding of solution concentration at the tertiary level. Chemistry Education Research and Practice, 13(1), 816. https://doi.org/10.1039/c1rp90056k

Damasio, A. R. (1994). Descartes' Error: Emotion, reason, and the human brain. New York, NY : Grosset, Putman.

Devetak, I., Vogrinc, J. et Glažar, S. A. (2008). Assessing 16year-old students' understanding of aqueous solution at submicroscopic level. Research in Science Education, 39(2), 157-179. https://doi.org/10.1007/s11165-007-9077-2

diSessa, A. A. (1983). Phenomenology and evolution of intuition. Dans D. Gentner et A. L. Stevens (dir.), Mental models (p. 15-33). Mahwah, NJ : Lawrence Erlbaum.

diSessa, A. A. (2006). A history of conceptual change research: Threads and fault lines. Dans R. K. Sawyer (dir.), The Cambridge handbook of the learning sciences (p. 265-281). Cambridge, Royaume-Uni : Cambridge University Press. 
diSessa, A. A. (2013). A bird's-eye view of the "Pieces" vs. "Coherence" controversy (From the "Pieces" side of the fence). Dans S. Vosniadou (dir.), International handbook of research on conceptual change ( $2^{\mathrm{e}}$ éd., p. 31-48). New York, NY: Routledge.

https://doi.org/10.4324/9780203154472.ch2

Duit, R. et Treagust, D. F. (2003). Conceptual change: A powerful framework for improving science teaching and learning. International Journal of Sciences Education, 25(6), 671-688. https://doi.org/10.1080/09500690305016

Dunbar, K. N., Fugelsang, J. A. et Stein, C. (2007). Do naive theories ever go away? Using brain and behavior to understand changes in concepts. Dans M. C. Lovett et P. Shah (dir.), Thinking with Data: 33'd Carnegie Symposium on Cognition (p. 193-206). Mahwah, NJ : Erlbaum.

Fugelsang, J. A. et Dunbar, K. N., (2005). Brain-based mechanism underlying complex causal thinking. Neuropsychologia, 43(8), 1204-1213.

https://doi.org/10.1016/j.neuropsychologia.2004.10.012

Gandillet, E. et Le Maréchal, J.-F. (2003, octobre). Conceptions et chimie des solutions ioniques. Actes de colloque des $3^{\text {es }}$ Rencontres scientifiques de l'ARDiST, Toulouse.

Khang, G. N. et Sai, C. L. (1987). Secondary school students' difficulties in learning the "Mole Concept" - A preliminary study in Singapore. Singapore Journal of Education, 8(1), 80-88. https://doi.org/10.1080/02188798708547617

Houdé, O. (2016a). Apprendre à résister aux automatismes. Cahiers pédagogiques, (527), 20-22.

Houdé, O. (2016b, mai). Comment aider les élèves à inhiber leurs erreurs scolaires persistantes. Conférence présentée au $5^{\mathrm{e}}$ Congrès de l'Association pour la recherche en neuroéducation, UQAM, Montréal (Canada), 24-27 mai 2016.

Houdé, O. (2004). La psychologie de l'enfant ( 6 éd.). Paris, France : Presses Universitaires de France.

Houdé, O. et Tzourio-Mazoyer, N. (2003). Neural foundations of logical and mathematical cognition. Nature Reviews Neuroscience, 4(6), 507-514. https://doi.org/10.1038/nrn1117

Houdé, O., Zago, L., Crivello, F., Moutier, S., Pineau, A., Mazoyer, B. et Tzourio-Mazoyer, N. (2001). Access to deductive logic depends on a right ventromedial prefrontal area devoted to emotion and feeling: Evidence from a training paradigm. NeuroImage, 14(6), 1486-1492. https://doi.org/10.1006/nimg.2001.0930

Houdé, O., Zago, L., Mellet, E., Moutier, S., Pineau, A., Mazoyer, B. et Tzourio-Mazoyer, N. (2000). Shifting from the perceptual brain to the logical brain: The neural impact of cognitive inhibition training. Journal of Cognitive Neurosciences, 12(5), 721-728.

https://doi.org/10.1162/089892900562525
International Union of Pure and Applied Chemistry (IUPAC). (2016). La dissolution d'un cristal de sel dans l'eau. http://old.iupac.org/didac/Didac\%20Fr/Didac01/Con tent/H04\%20-\%20H05.htm

Johnstone, A. H. (1993). The development of chemistry teaching: A changing response to changing demand. Journal of Chemical Education, 70(9), 701-705. https://doi.org/10.1021/ed070p701

Kuhn, T. S. (1983). La structure des révolutions scientifiques. Paris, France : Flammarion.

Legrand, J.-C. (2006). Cours de thermodynamique. Résumé. Formation d'ingénieurs en Matériaux. Ecole polytechnique universitaire Pierre et Marie Curie. http://www.edu.upmc.fr/chimie/jclegrand/partie1_0 6_07.pdf

Lubin, A., Lanoë, C., Pineau, A. et Rossi, S. (2012). Apprendre à inhiber: Une pédagogie innovante au service des apprentissages scolaires fondamentaux (mathématiques et orthographe) chez des élèves de 6 à 11 ans. Neuroeducation, 1(1), 55-84. https://doi.org/10.24046/neuroed.20120101.55

Masson, S. (2012). Etude des mécanismes cérébraux liés à l'expertise scientifique en électricité à l'aide de l'imagerie par résonance magnétique fonctionnelle. Thèse de doctorat inédite. Université du Québec à Montréal, Canada. http://www.archipel.uqam.ca/4876/1/D2287.pdf

Masson, S. (2016, mai). Cerveau, apprentissage et enseignement des mathématiques et des sciences: Comment aider les élèves à surmonter leurs difficultés? Conférence présentée au $5^{\mathrm{e}}$ Congrès de l'Association pour la recherche en neuroéducation, UQAM, Montréal (Canada), 24-27 mai 2016.

Minstrell, J. (2001). Facets of students' thinking: Designing to cross the gap from research to standards-based practice. Dans K. Crowley, C. D. Schunn et T. Okada (dir.), Designing for science: Implications for professional, instructional, and everyday science. Mahwah, $\mathrm{NJ}$ : Lawrence Erlbaum Associates.

Nivaldo, J. T. (2011). Chemistry: A molecular approach ( $2^{\mathrm{e}}$ éd.). Upper Saddle River, NJ : Pearson Prentice Hall.

Nussbaum, J. et Novick, S. (1982). Alternative frameworks, conceptual conflict and accommodation: Toward a principled teaching strategy. Instructional Science, 11(3), 183-200. https://doi.org/10.1007/bf00414279

Orange, C. et Orange-Ravachol, D. (2013). Le concept de représentation en didactique des sciences : Sa nécessaire composante épistémologique et ses conséquences. Recherches en éducation, 17, 46-61.

Posner, G. J., Strike, K. A., Hewson, P. W. et Gertzog, W. A. (1982). Accomodation of a scientific conception: Toward a theory of conceptual change. Science Education, 66(2), 211-227. https://doi.org/10.1002/sce.3730660207 
Potvin, P. (2013). Proposition for improving the classical models of conceptual change based on neuroeducational evidence: Conceptual prevalence. Neuroeducation, 2(1), 16-43. https://doi.org/10.24046/neuroed.20130201.16

Potvin, P. (2011). Manuel d'enseignement des sciences et de la technologie: Pour intéresser les élèves $d u$ secondaire. Québec, Canada : MultiMondes.

http://multim.com/titre/?ID=350

Potvin, P. et Cyr, G. (2017). Toward a durable prevalence of scientific conceptions: Tracking the effects of two interfering misconceptions about buoyancy from preschoolers to science teachers. Journal of Research in Science Teaching, 54(9), 1121-1142.

https://doi.org/10.1002/tea.21396

Potvin, P., Riopel, M. et Masson, S. (2007). Regards multiples sur l'enseignement des sciences. Québec, Canada: MultiMondes. http://multim.com/titre/?ID=212

Potvin, P., Sauriol, E. et Riopel, M. (2015). Experimental evidence of the superiority of the prevalence model of conceptual change over classical models and repetition. Journal of Research in Science Teaching, 52(8), 1082-1108. https://doi.org/10.1002/tea.21235

Reuter, Y., Cohen-Azria, C., Daunay, B., Delcambre, I. et Lahanier-Reuter, D. (2013). Dictionnaire des concepts fondamentaux des didactiques ( $3^{\mathrm{e}}$ éd.). Bruxelles, Belgique : De Boeck.

https://doi.org/10.3917/dbu.reute.2013.01

Rossi, S., Lubin, A., Lanoë, C. et Pineau, A. (2012). Une pédagogie du contrôle cognitif pour l'amélioration de l'attention à la consigne chez l'enfant de 4-5 ans. Neuroeducation, 1(1), 29-54. https://doi.org/10.24046/neuroed.20120101.29

Siegler, R. S. (1996). Emerging minds. The process of change in children's thinking. New York, NY: Oxford University Press.

Smith, C. A. et Lazarus, R. S. (1990). Emotion and adaptation. Dans L. A. Pervin (dir.), Handbook of Personality: Theory and Research (p. 609-637). New York, NY : Guilford.

Stavy R. et Tirosh D. (2000). How students (mis-)understand science and mathematics. Intuitive rules. New York, NY : Teachers College Press.

Strike, K. A. et Posner, G. J. (1992). A revisionist theory of conceptual change. Dans R. A. Duschl et R. J. Hamilton (dir.), Philosophy of science, cognitive psychology, and educational theory and practice (p. 147-176). Albany, NY : SUNY Press.

Tsaparlis, G. et Sevian, H. (dir.). (2013). Concepts of matter in science education. Dordrecht, Pays-Bas : Springer. https://doi.org/10.1007/978-94-007-5914-5
Tsoumpelis, L. et Gréa, J. (1995). Essai d'application de la théorie des situations en sciences physiques Apprentissage de la concentration molaire en classe de première S. Recherches en Didactique des Mathématiques, 15(2), 63-108. http://rdm.penseesauvage.com/Essai-dapplication-de-la-theorie.html

Tümay, H. (2016). Reconsidering learning difficulties and misconceptions in chemistry: Emergence in chemistry and its implications for chemical education. Chemistry Education Research and Practice, 17(2), 229-245. https://doi.org/10.1039/c6rp00008h

Van Lerberghe, L. (2017). Des conceptions naïves aux conceptions expertes grâce à un apprentissage alliant contrôle inhibiteur et conflit cognitif. Mise en application au travers de l'acquisition du concept de concentration massique en troisième générale option sciences. Mémoire de master en sciences de l'éducation. Université catholique de Louvain, Louvain-la-Neuve, Belgique. https://dial.uclouvain.be/memoire/ucl/fr/object/the sis\%3A8550

Vermersch, P. (2011). L'entretien d'explicitation ( $7^{e}$ éd.). Issyles-Moulineaux : ESF.

Viennot, L. (2008). Learning and conceptual understanding: Beyond simplistic ideas, what have we learned? International Commission on Physics Education. http://web.phys.ksu.edu/ICPE/Publications/teach2/ Viennot.pdf

Vosniadou, S. et Brewer, W. F. (1992). Mental models of the earth: A study of conceptual change in childhood. Cognitive Psychology, 24(4), 535-585. https://doi.org/10.1016/0010-0285(92)90018-w

Willame, B. (2017). Construction d'outils didactiques pour remédier aux difficultés d'apprentissage du concept de concentration en chimie dans le secondaire supérieur. Appui sur les neurosciences cognitives. Thèse de doctorat en didactique des sciences. Université de Namur. Namur, Belgique : Presses Universitaires de Namur. https://pure.unamur.be/ws/portalfiles/portal/35494 $\underline{384}$

Willame, B. et Snauwaert, P. (2015). Les difficultés rencontrées dans l'apprentissage du concept de concentration en chimie. Spiral-E. Revue de recherches en éducation, 55(1), 177-205. https://doi.org/10.3406/spira.2015.1743

Willame, B. et Snauwaert, P. (2016). Et si nous mettions du sel dans l'eau - Comment évoluent les conceptions des apprenants au fur et à mesure des apprentissages en chimie? Spectre, Revue de l'Association pour l'enseignement de la science et de la technologie au Québec, 45(3), 18-21. 


\section{ANNEXE 1}

\section{Pré-test}

1. Quelle expression correspond le mieux au concept de « concentration chimique » :

a) Quantité de soluté dans un volume de solvant

b) Rapport entre une quantité de soluté et le volume de solution*

c) Grande quantité de soluté dans une solution

d) Molécules de soluté qui se regroupent dans un solvant

e) Aucune des possibilités

f) Je ne sais pas

2. Dans l'expression de la concentration $\mathrm{C}$, que représente $\mathrm{V}$ ?
a) Le volume de solution*
b) Le volume de solvant
c) Le volume de soluté
d) Aucune des possibilités
e) Je ne sais pas

3. Une solution est préparée en dissolvant $100 \mathrm{~g}$ de chlorure de sodium $\mathrm{NaCl}$ dans $500 \mathrm{~mL}(0,500 \mathrm{~L})$ d'eau. Quelle est la concentration massique en $\mathrm{NaCl}$ obtenue ?
a) $0,200 \mathrm{~g} / \mathrm{L}$
b) $200 \mathrm{~g} / \mathrm{L}$
c) $5,00 \mathrm{~mL} / \mathrm{g}$
d) Il manque des informations pour répondre*
e) Aucune des possibilités

4. Pour préparer une solution aqueuse de chlorure de sodium ( $\mathrm{NaCl}$ dans l'eau) à $2 \mathrm{~g} / \mathrm{L}$, que faut-il faire ?
a) Placer $1 \mathrm{~L}$ d'eau dans une fiole et ajouter $2 \mathrm{~g}$ de $\mathrm{NaCl}$
b) Placer $2 \mathrm{~g}$ de $\mathrm{NaCl}$ dans une fiole et ajouter $1 \mathrm{~L}$ d'eau
c) Placer $2 \mathrm{~g}$ de $\mathrm{NaCl}$ dans une fiole et compléter avec de l'eau jusqu'à obtenir un volume de $1 \mathrm{~L}^{*}$
d) Les propositions a ou b parce que l'ordre d'ajout du soluté n'a pas d'importance
e) Aucune des possibilités
f) Je ne sais pas 


\section{ANNEXE 2}

\section{Outil visant le conflit cognitif}

Lis attentivement toutes les indications données, sans passer aucune ligne.

Le matériel nécessaire : Un porte tube avec

- 1 tube à essai contenant de l'eau dont le niveau est indiqué par un trait

- 1 tube à essai contenant du sel de cuisine

Complète les encadrés au fur et à mesure que cela est demandé sans revenir en arrière une fois l'étape complétée.

\section{Étape 1. Prévisions}

1.1. Si la totalité du sel contenu dans le tube à essai était versée dans l'eau et que l'agitation permettait la dissolution complète du sel, que ferait le niveau du liquide?

Choisis l'une des propositions :

Le niveau reste le même

Le niveau diminue en dessous du trait

Le niveau monte au dessus du trait

1.2. Explique ton choix en étant le plus explicite possible :

\section{Étape 2. Observations}

2.1. Verse maintenant la totalité du sel dans l'eau, bouche le tube avec le bouchon puis mélange pendant 30 secondes en bloquant le bouchon avec un doigt.

2.2. Que fait le niveau de liquide? Choisis l'une des propositions :

Le niveau reste le même

Le niveau diminue en dessous du trait

Le niveau monte au dessus du trait

2.3. Compare ce résultat à ta prévision. Avais-tu raison? oui ou non

Si tu as répondu «non » : comment expliques-tu l'évolution réelle du niveau de liquide? 


\title{
Perspectives théoriques à l'égard des fonctions exécutives en contexte éducatif chez les enfants d'âge préscolaire
}

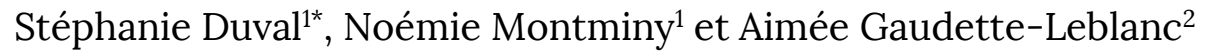

\section{RÉSUMÉ}

Cet article théorique vise à documenter l'évolution des perspectives qui ont été dégagées sur le développement des fonctions exécutives (FE) chez les enfants âgés entre 3 et 6 ans. Malgré la présence d'un accord général sur la définition plus large du concept de FE, un débat persiste toujours sur les composantes qui y sont associées, surtout chez les jeunes enfants. En effet, différentes propositions théoriques quant à la manière de conceptualiser les FE ont été proposées depuis le début des années 2000. Il est donc difficile de s'entendre sur les habiletés qu'il est possible d'observer chez les enfants d'âge préscolaire, notamment en contexte éducatif. Dans un tel contexte, il s'avère essentiel de miser sur l'observation des habiletés associées aux FE dans des situations quotidiennes et naturelles (p. ex. temps de jeu), ce qui permet ensuite à l'adulte d'accompagner l'enfant dans le déploiement de ces dernières. Prenant appui sur les perspectives théoriques dégagées dans cet article, notamment celle de Miyake et al. (2000), cet article propose des pistes d'observation et d'intervention permettant de soutenir les habiletés liées aux FE à l'éducation préscolaire, de manière à favoriser le développement et l'apprentissage de l'enfant, par extension sa réussite éducative.

\footnotetext{
${ }^{1}$ Université Laval, Faculté des sciences de l'éducation, Département d'études sur l'enseignement et l'apprentissage, Québec, Canada

${ }^{2}$ Université Laval, Faculté de musique, Programme d'éducation musicale, Québec, Canada

* Correspondance avec l'auteure : stephanie.duval@fse.ulaval.ca
}

Pour citer cet article : Duval, S., Montminy, N. et Gaudette-Leblanc, A. (2018). Perspectives théoriques à l'égard des fonctions exécutives en contexte éducatif chez les enfants d'âge préscolaire. Neuroéducation, 5(2), 93-108.

DOI: $\underline{\text { https://doi.org/10.24046/neuroed.20180502.93 }}$

Reçu le $1^{\text {er }}$ novembre 2017. Révision reçue le 27 avril 2018.

Accepté le 10 mai 2018. Publié en ligne le 19 septembre 2018.

Neuroéducation, 5(2), 93-108

ISSN: 1929-1833

Tous droits réservés C 2018 - Association pour la recherche en neuroéducation 


\section{Introduction}

Jusqu'à tout récemment, l'étude des fonctions exécutives (FE) a principalement été le domaine des neurologues et des neuropsychologues (Anderson, Jacobs et Anderson, 2008; Denckla, 1996; Diamond, 2006; Holmes-Bernstein et Waber, 1990). Une attention accrue est présentement portée envers ces fonctions cognitives de haut niveau dans le monde de l'éducation (p. ex. Diamond, 2016). Pour cause, les FE permettent d'assurer le «contrôle cognitif » de l'enfant, car elles lui permettent de raisonner, de planifier, de concentrer son attention et d'inhiber les comportements jugés non appropriés dans le contexte où il se trouve (Chevalier, 2010). De cette manière, les FE lui permettent de contrôler intentionnellement sa pensée et ses actions dans l'atteinte d'un but précis (Chevalier, 2010; Miyake et al., 2000).

$\mathrm{Au}$ plan international, de plus en plus de chercheurs soulignent l'importance d'étudier les FE chez l'enfant, particulièrement à la période de 3 à 6 ans qui s'avère critique pour leur développement (Diamond, 2016). De manière plus précise, des travaux font ressortir des liens entre les FE, définies comme un ensemble de processus cognitifs interdépendants, et la réussite éducative de l'enfant, dès son entrée à la maternelle (p. ex. Engel de Abreu et al., 2014). Des études ont d'ailleurs montré que les enfants de la maternelle qui démontraient de meilleures $\mathrm{FE}$, telles que mesurées à l'aide de tests standardisés, s'engageaient plus efficacement dans les situations d'apprentissage offertes en première année du primaire (Blair et Raver, 2014; Williford et al., 2013).

Ces études montrent qu'un intérêt est porté envers l'étude des FE en contexte éducatif, notamment lors de la transition de l'éducation préscolaire vers l'enseignement primaire. Ce moment, qui marque le passage de l'enfant d'un milieu où l'apprentissage par le jeu est valorisé (éducation préscolaire) vers un environnement où l'enseignement plus formel de domaines disciplinaires (p. ex. mathématiques, lecture, etc.) est préconisé (Moreno, Shwayder et Friedman, 2016), amène l'enfant à déployer plusieurs habiletés associées aux FE.

Si des études ont examiné le lien entre les FE de l'enfant et sa performance dans les tâches scolaires, peu d'entre elles ont spécifiquement porté sur les habiletés associées aux FE en contexte d'éducation préscolaire. Ces habiletés sont pourtant sollicitées lors de situations naturelles et quotidiennes de classe, par exemple en situation de jeu (Moreno et al., 2016). De plus, bien qu'une attention soit actuellement portée envers la réussite éducative de l'enfant dès son entrée à l'école (Bierman et Torres, 2016; Simard et al., 2013), on se questionne toujours sur les pratiques enseignantes les plus optimales à mettre en place en classe, de manière à favoriser le développement et l'apprentissage de chacun.

À l'avis de plusieurs chercheurs, on se questionne davantage sur comment intervenir auprès de l'enfant afin de l'amener à réaliser des apprentissages, souvent axés sur les domaines disciplinaires (p. ex. mathématiques) (p. ex. Hirsh-Pasek et al., 2008; Pellegrini, 2009). Cependant, dans une perspective développementale, soit celle privilégiée par les programmes éducatifs pour les enfants d'âge préscolaire (MEQ, 2006; MFA, 2007), on devrait miser sur comment les enfants apprennent, de manière à guider les pratiques enseignantes selon les besoins de chacun.

Dans cette perspective, l'enfant est perçu comme un apprenant actif qui, grâce à ses interactions avec le monde qui l'entoure, construit des connaissances, habiletés et attitudes qui lui permettent d'évoluer et de s'adapter continuellement à travers ses nouvelles expériences (HirshPasek et al., 2008). Afin de miser sur une approche centrée sur l'enfant et préconisant l'apprentissage actif (p. ex. situations de jeu), il semble primordial de comprendre l'évolution du développement des FE chez l'enfant d'âge préscolaire, de manière à examiner comment les habiletés ${ }^{1} \mathrm{y}$ étant reliées peuvent être mises à contribution (observation), pour ultimement mieux accompagner l'enfant (intervention).

Selon Moreno et al. (2016), en dépit d'un accord général sur la définition plus large du concept de $\mathrm{FE}$, un débat persiste toujours sur les composantes ${ }^{1}$ qui y sont associées, surtout chez les jeunes enfants. Il est donc difficile de s'entendre sur les habiletés qu'il est possible d'observer en contexte éducatif, afin de soutenir efficacement l'enfant dès l'éducation préscolaire. Quelles sont les composantes qui sont associées aux FE chez les enfants âgés entre 3 et 6 ans? Comment l'adulte peut-il observer les habiletés liées aux FE en contexte éducatif, pour ensuite ajuster ses interventions visant à les favoriser chez l'enfant? Voilà les questions qui sous-tendent cet article de nature théorique.

\section{Les FE chez l'enfant d'âge préscolaire}

Malgré la présence d'un débat permanent sur la nature des composantes liées aux FE à la petite enfance (c.-à-d., une composante globale ou des composantes différenciées) (Skogan et al., 2015; van der Ven et al., 2012), l'importance d'examiner leur développement à l'âge préscolaire est reconnue (Moreno et al., 2016). En effet, certaines périodes de la vie semblent plus propices au développement des FE (périodes dites critiques) (Kagan et Baird, 2004; Zelazo, 2013), ce qui justifie la pertinence d'y porter attention à ce moment charnière dans la vie de l'enfant.

En neuropsychologie, le concept de FE renvoie couramment à un terme «parapluie » qui englobe un ensemble de processus cognitifs nécessaires à la réalisation d'un comportement dirigé vers un but, sous la gouverne principale du cortex préfrontal et de ses réseaux (Bear, Connors et Paradiso, 2016; Roy, 2012). En éducation, les données de

\footnotetext{
${ }^{1}$ Le terme «habileté » est privilégié dans cet article, lequel réfère aux manifestations observables des FE à l'éducation préscolaire. Le terme « composante » fait plutôt référence à l'activité mentale pouvant être comprise dans ce que l'on appelle «la cognition » (Fortin et Rousseau, 2012). Dans cet article, la mémoire de travail, l'inhibition et la flexibilité mentale ont été retenues comme les composantes principales des FE.
} 
certaines études (Foy et Mann, 2012; Mann et al., 2016) mènent à penser que les FE pourraient constituer l'élément qui unit toutes les dimensions du développement global de l'enfant d'âge préscolaire ${ }^{2}$. Ainsi, on peut penser que les FE constitueraient la pierre angulaire du développement et de l'apprentissage de l'enfant et qu'autour d'elles convergeraient plusieurs stratégies, habiletés et connaissances (Duval et Bouchard, 2013).

Selon Fuhs, Farran et Nesbitt (2013), bien qu'il demeure pertinent de parler d'une seule FE plutôt que des FE (composante globale versus composantes différenciées) à l'âge préscolaire, force est de constater qu'une coordination de certaines habiletés associées aux FE s'avère primordiale dès l'entrée à l'école. Prenons l'exemple d'une situation de jeu incluant des blocs de bois : l'enfant pourrait alors user de ses habiletés d'inhibition en déplaçant minutieusement les blocs pour arriver à construire une tour formée de plusieurs étages. Il pourrait également mettre en œuvre sa flexibilité mentale, par exemple si un autre enfant propose une stratégie qui n'était pas envisagée initialement et qui contribue à bonifier la construction en cours. Lorsque l'enfant s'engage dans des situations qui lui permettent de coordonner ses habiletés liées aux FE, il arrive ainsi à mettre en place des actions et des pensées orientées vers des buts précis. Cet exemple illustre que plusieurs FE peuvent être sollicitées lors d'une même situation à l'éducation préscolaire.

De manière à bien les observer en contexte éducatif, il importe d'abord de bien comprendre ces composantes, d'autant plus qu'il est démontré que les FE de l'enfant de la maternelle prédisent ses succès futurs (Foy et Mann, 2012; Mann et al., 2016). À titre illustratif, Blair et Razza (2007) ont montré que les composantes «mémoire de travail» et « inhibition » permettraient de prédire le rendement scolaire des enfants en mathématiques et en lecture, dès leur entrée au primaire. Dans le même sens, une étude menée par Kroesbergen, Van Luit, Van Lieshout, Van Loosbroek et Van de Rijt (2009) a montré que chez les enfants de 5-6 ans, les FE «mémoire de travail» et «inhibition » étaient notamment associées aux compétences en mathématiques. Par ailleurs, des études ont aussi montré l'importance des FE dans le développement social des jeunes enfants, lequel s'avère également impliqué dans leur réussite éducative présente et ultérieure (Bull, Espy et Wiebe, 2008; Clark, Pritchard et Woodward, 2010; Röthlisberger et al., 2011).

Bien que ces travaux dévoilent des liens précis entre les composantes liées aux FE chez les enfants et leur réussite éducative, il importe de noter que l'émergence des connaissances associées au développement des FE chez l'enfant est encore récente (Roy, 2012). En effet, la transposition de connaissances acquises sur le développement des FE découle d'abord des travaux en neuropsychologie réalisés chez l'adulte. Les études menées auprès de l'enfant utilisent parfois la tendance générale en employant des tests conçus pour l'adulte (Ibid.), lesquels sont généralement effectués en laboratoire. Ainsi, s'il est vrai que l'acquisition des connaissances sur les FE issues des travaux en neuropsychologie chez l'adulte a permis de constituer un cadre de référence théorique sur leur développement des FE, il s'avère essentiel de demeurer prudent sur la transposition qu'on peut $y$ faire chez l'enfant. Effectivement, les propositions théoriques concernant la manière de conceptualiser les FE chez les enfants, basées sur ce que l'on connait du cerveau adulte, s'avèrent hypothétiques en raison du développement cérébral qui n'est pas à sa pleine maturité.

Le fait de s'intéresser à l'évolution développementale des FE chez l'enfant d'âge préscolaire pourrait permettre de dégager des pistes d'observation et d'intervention pour les adultes qui les accompagnent (p. ex. enseignants de maternelle), tel qu'il est proposé dans la discussion de cet article. À l'éducation préscolaire, l'observation quotidienne des enfants constitue un outil de premier ordre pour connaitre les potentionnalités de chacun afin de les accompagner dans leurs apprentissages (MFA, 2007). En observant les habiletés associées aux FE chez l'enfant, l'adulte pourra ainsi examiner ce que l'enfant est capable de faire seul par l'exploration de son environnement, et il pourra complexifier les situations d'apprentissage et de développement afin que ce dernier progresse harmonieusement, de manière à respecter son rythme qui lui est propre.

Pour y parvenir, il importe d'abord de dégager les perspectives théoriques actuelles qui sont proposées afin de comprendre le développement des FE chez les enfants. Peuton supposer que plusieurs habiletés composent les FE chez les enfants, tel que chez les adultes?

\section{Cadre théorique}

Les FE s'avèrent des fonctions psychologiques supérieures, qualifiées de complexes et étant influencées par l'environnement culturel et social (Luria, 1966). Certaines périodes de la vie (p. ex. 3 à 6 ans) sont plus critiques pour leur formation, car elles coïncident avec le développement du cortex préfrontal (De Luca et Leventer, 2008). Le développement de cette région cérébrale est caractérisé par une maturité ontogénétique particulièrement tardive (Dennis, 2006); les fonctions dévolues au cortex préfrontal du cerveau se développent ainsi graduellement pendant l'enfance, et ce, jusqu'à l'âge adulte. Bien que le cortex préfrontal n'atteigne pas sa maturité avant l'âge adulte, les éléments-clés qui le composent, tels que les FE, sont présents tôt dans la vie et doivent être reconfigurés tout au long de l'enfance (Roy, 2012). Ainsi, le développement des FE chez l'enfant est à la fois précoce et prolongé, en raison de la maturation du cortex préfrontal.

Selon Luria (1966), premier chercheur à avoir introduit le terme « FE » dans ses recherches, les fonctions cognitives de haut niveau se développent d'abord grâce aux interactions entre l'enfant et les adultes qui l'entourent (p. ex. parent,

\footnotetext{
${ }^{2}$ Le développement global peut être défini comme le développement simultané, intégré, graduel et continu de toutes les dimensions qui composent

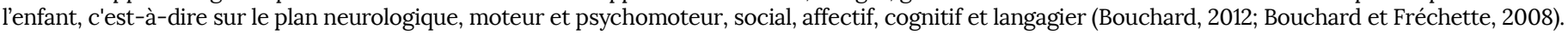


enseignant). Luria considère l'activité humaine selon une approche systémique, c'est-à-dire une approche permettant de considérer différents facteurs d'influence dans le développement et l'apprentissage de l'enfant. De ce point de vue, l'histoire personnelle de l'enfant exerce une influence sur son esprit, ce qui lui permet d'adapter ses comportements aux différents contextes dans lesquels il évolue (p. ex. contexte éducatif). Selon Luria (1966), Vygotski serait le premier chercheur à avoir examiné les principes qui soustendent la relation entre le cerveau et le comportement.

Selon la théorie vygotskienne, le développement de l'enfant est le fruit d'une genèse sociale et il doit être compris dans une perspective historico-culturelle. Vygotski (1997) affirme que le contexte social façonne les processus mentaux de l'enfant, en plus de faire partie intégrante de son processus développemental (Bodrova et Leong, 2010). De cette manière, les comportements individuels découlent de l'interaction entre l'enfant et l'environnement dans lequel il évolue. Vygotski $^{3}$ (1978) distingue deux catégories de processus mentaux : 1) les fonctions psychiques élémentaires, qui sont biologiquement déterminées et 2) les fonctions psychiques supérieures, qui ont des origines socioculturelles. La culture touche à la fois au développement des fonctions psychiques supérieures et à la façon dont elles sont acquises (Bodrova et Leong, 2010), tandis que les processus élémentaires produisent l'activité générale et fondamentale de la plupart des hémisphères cérébraux (Vocate, 1987). En somme, tant pour Vygotski que pour Luria, les FE transcendent l'expérience de l'enfant et reflètent le niveau culturel de son environnement social.

Suite aux travaux de Vygotski et de Luria, de nombreux chercheurs ont tenté d'étudier plus finement le développement des FE (p. ex. Diamond, 2013; Miyake et Friedman, 2012). Dans de nombreuses études portant sur les FE chez les enfants d'âge préscolaire, les chercheurs s'entendent sur le fait qu'il existerait au moins trois composantes fondamentales y étant liées : la mémoire de travail, l'inhibition et la flexibilité mentale (Jacob et Parkinson, 2015; Miyake et al., 2000).

\subsection{La mémoire de travail}

La mémoire de travail représente une pièce maîtresse dans le développement des FE. En contexte éducatif, elle permet à l'enfant de retenir une information et de l'utiliser d'une manière appropriée dans un autre contexte (Diamond, 2013). Cette composante des FE réfère ainsi à la capacité de stocker temporairement des informations en mémoire, afin de les manipuler et de les contrôler ultérieurement (Dekker, Ziermans et Swaab, 2016).

À l'éducation préscolaire, l'enfant pourrait par exemple user d'habiletés liées à la mémoire de travail lors de la lecture d'une histoire, lorsque l'adulte lui pose des questions sur les évènements et les personnages (p. ex. Dans cette histoire, quelle est l'activité préférée de l'ours? Que s'est-il passé avant qu'il parte en camping?). De même, si l'adulte invite l'enfant à faire des liens entre l'histoire et sa vie personnelle, ce dernier sera amené à utiliser différentes habiletés de mémoire (p. ex. Et toi, es-tu déjà allé en camping? Que faisais-tu comme activité? Est-ce semblable à ce que l'ours fait dans cette histoire?). Selon plusieurs auteurs (p. ex. Best et Miller, 2010; Best, Miller et Jones, 2009), cette FE s'améliore progressivement au cours de l'enfance et de l'adolescence, et ce, de façon linéaire.

\subsection{L'inhibition}

L'inhibition permet à l'enfant de contrôler des actions ou de résister à des interférences qui proviennent de stimuli externes et qui ne sont pas pertinents dans la situation actuelle. Cette composante est considérée comme une habileté préalable pour l'acquisition des autres FE (Dekker et al., 2016). À l'éducation préscolaire, l'enfant pourrait user d'habiletés liées à l'inhibition lors d'un jeu de construction, par exemple. En voulant construire une tour de huit étages (comme celle devant sa maison), un enfant pourrait alors être amené à contrôler ses gestes pour que la tour ne s'effondre pas en cours de construction. Cet enfant devra alors adapter ses gestes en fonction de l'environnement, de manière à répondre à l'objectif qu'il s'est lui-même fixé. Si la tour s'effondre, il sera amené à réguler ses émotions (p. ex. se féliciter d'avoir fait cinq étages au lieu d'être fâché de ne pas en avoir réalisé huit), ce qui est également associé à l'inhibition.

À l'âge préscolaire, les capacités d'inhibition s'améliorent rapidement. C'est plus précisément vers l'âge de 4 ans que l'enfant présente des habiletés de base liées à l'inhibition. À cet âge, l'enfant réussirait mieux les tâches d'inhibition motrices que celles d'inhibition verbale (Best et Miller, 2010). Cette composante des FE poursuivrait son développement de façon graduelle et linéaire entre l'âge de 5 à 8 ans. (Best et al., 2009).

\subsection{La flexibilité mentale}

Cette composante réfère à la capacité de l'enfant à changer de tâche ou de stratégie afin de passer d'une opération cognitive à une autre (Chevalier, 2010). De manière plus précise, cette FE lui permet de désengager son attention visà-vis une situation, afin de s'engager dans une nouvelle, en fonction des exigences de cette dernière. À l'éducation préscolaire, l'enfant pourrait user d'habiletés liées à la flexibilité mentale en suivant les règles associées à une routine précise (p. ex. transiter du coin blocs vers la collation) ou en s'engageant dans un rôle au coin jeu symbolique (p. ex. passer du statut «enfant » à celui de « commis d'épicerie », en suivant les règles associées au jeu).

Rappelons qu'actuellement, un vif intérêt est porté envers l'étude des FE en contexte éducatif, notamment à l'éducation

${ }^{3}$ S'écrit Vygotsky, dans les références, dans le cas de ses publications en anglais. 
préscolaire (p. ex. Moreno et al., 2016). Bien que plusieurs chercheurs s'entendent sur le fait que la période préscolaire constitue un moment où l'on observe d'importants changements cognitifs (Diamond, 2013; Hoskyn, Iarocci et Young, 2017), très peu arrivent à un consensus quant à la forme que prennent ces derniers. Les prochaines sections visent à dégager les principales manières de conceptualiser les FE chez l'enfant âgé entre 3 et 6 ans, à partir des études qui ont été diffusées depuis le début des années 2000.

\section{Différentes perspectives développementales}

Knapp et Morton (2017) soulignent que plusieurs transformations particulièrement prononcées apparaissent dans le développement des FE lors de la petite enfance. Selon les chercheurs, la maturation du cerveau suit un continuum de développement prolongé, en concordance avec le développement du cortex préfrontal qui s'échelonne sur une longue période de temps (Ibid.). En effet, les circuits neuronaux associés au développement des FE s'avèrent lents à se développer, car les régions préfrontales du cerveau atteignent leur maturité seulement au début de l'âge adulte (Lenroot et Giedd, 2006). De manière similaire, les habiletés liées aux FE continuent de s'améliorer dans la deuxième décennie de la vie. L'existence de ces similitudes dans les trajectoires de développement entre le cortex préfrontal du cerveau et les habiletés liées aux $\mathrm{FE}$ a conduit à beaucoup de recherches dédiées à examiner cette relation plus en profondeur.

Des études ont examiné les différences liées à l'âge dans le fonctionnement du cerveau au cours de la réalisation de tâches liées aux FE, et ce, pour suggérer que ces deux processus de développement semblent étroitement liés. Cependant, il existe un certain désaccord quant à la façon de décrire l'évolution du cortex préfrontal tout au long de l'enfance et d'expliquer l'effet de celle-ci sur le développement des FE (Knapp et Morton, 2017).

Il existe également un certain désaccord sur la manière de conceptualiser les FE chez l'enfant. L'une des grandes approches permettant de conceptualiser les FE pointe vers une structure unitaire, qui suggère qu'une seule FE serait observée chez l'enfant, laquelle serait composée de plusieurs habiletés communes et indissociables.

\subsection{Modèle théorique à une composante (structure unitaire)}

Un nombre important d'études concernant le développement des FE chez les enfants âgés de 3 ans et moins (p. ex. Wiebe et al., 2011; Willoughby et al., 2010; Willoughby, Wirth et Blair, 2012) présentent un modèle de FE à structure unitaire, lequel diffère de la structure proposée pour les enfants plus âgés.

L'hypothèse selon laquelle le fonctionnement exécutif serait d'abord composé d'un construit unique (une seule FE) correspond à la théorie selon laquelle les activités mentales seraient initialement générales, puis se spécialiseraient progressivement avec l'âge et l'expérience (Clark et al., 2013). Selon cette perspective théorique, les composantes associées aux FE (p. ex. mémoire de travail, inhibition) seraient relativement indifférenciées, notamment en début de vie (Diamond, 2013; Hughes et al., 2009; Roebers, 2017; Wiebe et al., 2011).

Bien que certaines études supportent également une structure unitaire dans le développement des FE chez les enfants âgés entre quatre et cinq ans (p. ex. Fuhs et Day, 2011; Shing et al., 2010; Wiebe, Espy et Charak, 2008), il semble qu'on pourrait différencier les composantes associées aux FE au fur et à mesure que l'enfant grandit, et ce, à partir de l'âge de 4 ans environ. En fait, il en reste encore beaucoup à apprendre sur le moment où la transition de la structure unitaire vers la structure nommée « unité/diversité 》 émerge, telle que suggérée par Miyake et Friedman (2012).

\subsection{Le modèle théorique unité/diversité}

Les analyses factorielles confirmatoires effectuées dans les travaux de Miyake et al. (2000) ont montré que les FE peuvent être conceptualisées en trois composantes principales : la mémoire de travail, l'inhibition et la flexibilité mentale. Ces trois composantes associées aux FE peuvent être conceptualisées dans un cadre nommé « unité/diversité » (Fujisawa, Todo et Ando, 2016). Cette manière de les conceptualiser suppose que ces trois composantes sont corrélées les unes aux autres et partagent plusieurs processus sous-jacents communs (unité), mais qu'elles présentent également certains degrés de séparabilité (diversité) (Miyake et al., 2000).

Suite aux travaux de Miyake et al. (2000), plusieurs chercheurs ont proposé des modèles théoriques suggérant une structure à trois composantes dans l'étude des FE chez les enfants d'âge préscolaire (p. ex. Best et Miller 2010; Best et al., 2009; Garon, Bryson et Smith, 2008). Selon ces auteurs, les composantes des FE partageraient des caractéristiques communes, mais elles seraient également indépendantes. Par exemple, Garon et al. (2008) ont effectué des analyses factorielles confirmatoires dévoilant que trois composantes formaient le concept de FE (mémoire de travail, inhibition, flexibilité mentale). Lors de leurs analyses, les chercheurs ont démontré que ces composantes s'avéreraient partiellement indépendantes, tout en étant corrélées entre elles.

Toujours en s'appuyant sur les travaux de Miyake et al. (2000), Best et Miller (2010) ont défini un modèle à trois composantes ayant différentes trajectoires développementales. Plus précisément, ces derniers ont proposé que le degré de corrélation et d'indépendance des $\mathrm{FE}$ variait selon l'âge de l'enfant. Par exemple, les chercheurs soulignent que l'inhibition se développerait plus rapidement pendant les années préscolaires (3-6 ans), tandis que la mémoire de travail et la flexibilité mentale évolueraient de manière linéaire et progressive tout au long de l'enfance.

En 2012, Miyake et Friedman ont proposé que chacune de ces composantes pouvait être décomposée (diversité), tout en conservant des particularités communes (unité). La figure 1 illustre le modèle de Miyake et Friedman (2012), par une représentation schématique de l'unité et de la diversité. Cette figure montre que les habiletés reliées à chacune des 
composantes (p. ex. mémoire de travail) comportent des processus cognitifs communs aux trois FE (FE commune). Toutefois, chaque composante est constituée de processus cognitifs spécifiques (p. ex. processus spécifique à la mémoire de travail) (voir figure 1).

La figure 1 dévoile également qu'en comparaison avec les processus spécifiques à la mémoire de travail et la flexibilité mentale, l'inhibition s'avère uniquement comprise dans la FE commune (unité). En effet, cette composante (inhibition) serait la seule à s'expliquer par l'unité, car elle présente des particularités communes aux autres composantes (Miyake et Friedman, 2012). Plus précisément, Miyake et Friedman (2012) ont montré que l'inhibition corrèle fortement et significativement avec les deux autres composantes, ce qui mène à la considérer comme une « FE commune » (unité).

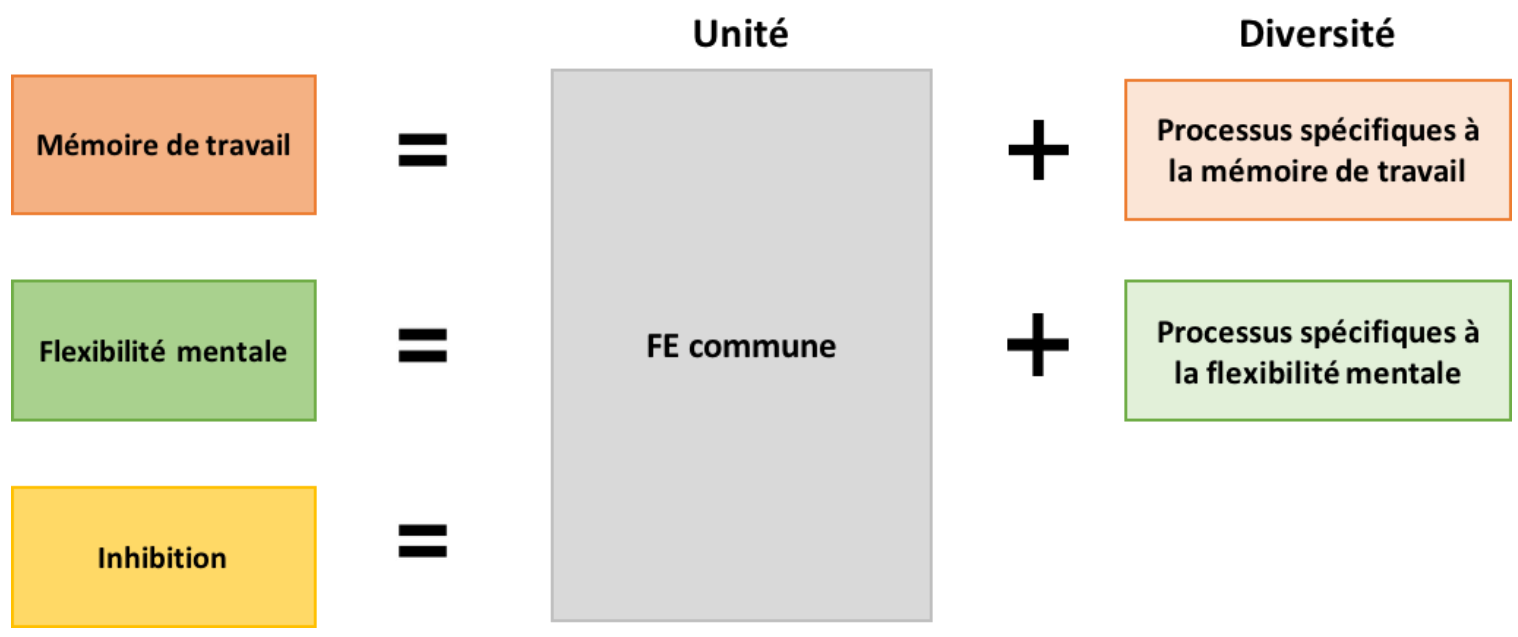

Figure 1. Représentation schématique de l'unité et de la diversité des trois composantes principales des FE. (figure inspirée de Miyake et Friedman, 2012).

Ce qui émerge de la proposition théorique dégagée par ces chercheuses pointe vers la complexité de la composante « inhibition ». Celle-ci représente une composante en soi, mais elle constitue également un facteur général de contrôle exécutif qui influence les autres composantes y étant liées (Ibid.). Suite aux travaux de Miyake et Friedman (2012), Diamond (2013) a suggéré qu'une relation bidirectionnelle existait entre l'inhibition et la mémoire de travail, les décrivant comme des composantes séparées, mais fortement reliées.

Il importe de mentionner que les modèles proposés par Miyake et ses collaborateurs (Miyake et al., 2000; Miyake et Friedman, 2012) ont été élaborés à partir d'un échantillon de participants adultes. Cependant, il s'avère pertinent de les présenter, car plusieurs auteurs se sont par la suite inspirés de ces modèles en tentant de les appliquer à des échantillons d'âges variables. Il est à souligner que le développement des FE apparait selon un modèle de stades développementaux plutôt que de manière statique. Ainsi, les FE de l'enfant progressent selon le rythme de développement de chacun, et non selon un cadre fixe et invariable pour tous les individus. Il s'avère donc difficile de préciser l'âge exact où l'on peut considérer l'un ou l'autre des modèles théoriques.

À titre illustratif, de nombreuses études ont montré qu'une diversité de FE existait chez les enfants d'âge primaire (7 à 12 ans) (p. ex. Engelhardt et al., 2015; Huizinga, Dolan et van der
Molen, 2006; Lehto et al., 2003; Shing et al., 2010), tandis que d'autres chercheurs ont démontré que cette différenciation pouvait se produire un peu plus tôt (p. ex. Miller et al., 2012; Usai et al., 2013), tel qu'à l'âge préscolaire (3 à 6 ans). Néanmoins, un aspect commun unit ces travaux: ils proposent un modèle théorique formé de trois composantes (mémoire de travail, flexibilité mentale et inhibition), lesquelles s'avèrent corrélées entre elles, tout en présentant un caractère dissociable. Outre ces travaux, d'autres chercheurs identifient une structure des FE à deux composantes.

\subsection{Modèle théorique à deux composantes}

Des chercheurs suggèrent une structure formée de deux composantes chez les enfants âgés entre 4 et 5 ans (Lee, Bull et Ho, 2013; van der Ven et al., 2012). Cette structure serait plus précisément composée de 1) l'inhibition, puis de 2) la mémoire de travail et de la flexibilité mentale en tant que FE combinées (Lee et al., 2013; van der Ven et al., 2012). Par ailleurs, d'autres chercheurs (p. ex. Miller et al., 2012; Usai et al., 2013) ont montré l'existence d'un autre modèle théorique, lequel serait formé de ces deux composantes : 1) la mémoire de travail, puis 2) l'inhibition et la flexibilité mentale (FE combinées). En 2015, Monette, Bigras et Lafrenière (2015) ont supporté ce dernier modèle, en suggérant que les composantes « mémoire de travail » et « inhibition/flexibilité mentale » pouvaient être observées chez les enfants âgés 
entre 4 et 5 ans. Selon ces chercheurs, ces deux composantes se développeraient en premier durant l'enfance.

Quoi qu'il en soit, ces différentes études, voire ces différentes manières de conceptualiser les $\mathrm{FE}$, démontrent que leur structure tend à se transformer avec l'âge des enfants. C'est pourquoi Johansson, Marciszko, Brocki et Bohlin (2015) soutiennent qu'on peut observer des améliorations graduelles dans les composantes qui forment les $\mathrm{FE}$, lesquelles deviennent de plus en plus complexes avec l'âge. Un dernier modèle théorique s'oriente d'ailleurs vers une perspective hiérarchique et évolutive de la structure des FE.

\subsection{Perspective liée à un développement hiérarchique des FE}

Selon Johansson et al. (2015), les FE seraient d'abord composées par une structure unitaire (0-3 ans), avant d'être séparées en deux composantes vers l'âge de 3 à 4 ans. Un modèle formé de trois composantes serait ensuite dégagé, lesquelles apparaitraient plus tard dans le développement de l'enfant (Ibid.). Ainsi, il semble que les différentes perspectives théoriques qui ont préalablement été dévoilées puissent être réconciliées, en supposant que l'inhibition, la flexibilité mentale et la mémoire de travail constitueraient différentes composantes qui se différencieraient progressivement les unes des autres, et ce, en fonction de l'âge de l'enfant (Clark et al., 2013; Wiebe et al., 2011).

En ce sens, Garon et al. (2008), de même que Garon, Smith et Bryson (2013), ont proposé que les composantes associées aux FE se développeraient de manière séquentielle. Plus précisément, on verrait d'abord apparaitre la mémoire de travail en tant que composante distincte, suivie de l'inhibition, puis de la flexibilité mentale. Ainsi, on pourrait affirmer que ces trois composantes s'avèrent indépendantes, mais que le développement de chacune serait lié à celui des autres. Dans le même ordre d'idées, Diamond (2006) suggère que les FE représentent des processus cognitifs indépendants qui présentent une trajectoire développementale différente. Bien que la période située entre 3 et 6 ans s'avère critique pour leur développement, ce dernier s'avère progressif et linéaire, en plus d'être différent pour chaque enfant (rythme de développement unique) (Diamond, 2002).

\section{Synthèse des différentes perspectives théoriques dégagées}

Les sections précédentes ont permis de dégager une perspective évolutive dans le développement du fonctionnement exécutif durant l'enfance (3-6 ans). On peut notamment observer que la structure des FE se modifie progressivement au fil du développement, en raison de la maturation du cortex préfrontal (Knapp et Morton, 2017). En effet, différentes conceptions des FE ont été proposées depuis le début des années 2000, selon le point de vue théorique et le groupe d'âge examiné. Étant donné que la procédure d'évaluation et l'interprétation des résultats sont majoritairement basées sur l'un ou l'autre des modèles proposés pour examiner les habiletés liées aux FE chez l'enfant, il demeure important d'envisager différentes manières de conceptualiser les FE en cours de développement (Ibid.).

Les différentes conceptualisations des FE tendent historiquement à se situer selon deux grandes approches : 1) la perspective unitaire, qui met en évidence des composantes communes et indissociables des FE; et 2) la perspective présentant des composantes liées aux FE différenciées et interreliées (Knapp et Morton, 2017). En fait, il existe des preuves considérables qui soutiennent la perspective unitaire des FE chez le jeune enfant, y compris une forte corrélation entre les mesures utilisées (Carlson, Mandell et William, 2004; Friedman et Miyake, 2004). On verrait ensuite apparaitre une croissance progressive liée à la performance des FE au cours de la période comprise entre 4 et 6 ans. Des analyses factorielles confirmatoires ont également montré que plusieurs composantes seraient associées aux FE à partir de l'âge de quatre ans environ. Enfin, les changements liés à la structure des FE durant l'enfance seraient liés à la complexité hiérarchique des composantes (mémoire de travail, inhibition et flexibilité mentale) y étant associées, qui amènent les enfants à résoudre des problèmes de plus en plus difficiles au fur et à mesure qu'ils se développent (Zelazo et Müller, 2010).

Le développement des FE a traditionnellement été étudié à partir de perspectives biologiques ou neuropsychologiques en lien avec le développement du cortex préfrontal, qui devient mature plus lentement que d'autres régions du cerveau (Garon et al., 2008). Cependant, des recherches plus récentes ont mis l'accent sur les influences environnementales associées aux différences individuelles dans les FE et à son développement (Bernier et al., 2011; Raver, Blair et Willoughby, 2013; Rhoades et al., 2011). Ces études montrent notamment qu'il s'avère possible de soutenir les FE chez les enfants d'âge préscolaire, soit lors d'une étape transitoire importante dans leur développement (Fujisawa et al., 2016). Considérant les changements développementaux dans les FE lors de cette période, il serait plus facile de distinguer les composantes y étant liées au fur et à mesure que l'enfant se développe, soit à partir de 4 ans environ. On peut alors se poser la question suivante : à partir 4 ans, estce possible de distinguer les composantes associées aux FE chez l'enfant, à l'aide d'habiletés observées en contexte éducatif?

Selon Isquith, Gioia et Epsy (2004), il est d'abord nécessaire d'observer les habiletés associées aux FE quotidiennement en contexte éducatif pour ensuite les soutenir de manière efficace. Effectivement, l'observation est le premier jalon de lintervention éducative (MFA, 2007), car elle permet à l'enseignant de situer le niveau de développement global des enfants qui composent sa classe. Mieux connaitre et comprendre chacun des enfants, grâce aux observations effectuées lors de situations naturelles de classe, offre à l'adulte des pistes pour ensuite planifier et ajuster ses interventions, de manière à mieux soutenir les 
apprentissages et le développement de chacun. En ce sens, les prochains paragraphes ont pour objectif de discuter des habiletés observables liées aux FE en contexte éducatif, plus précisément en maternelle (4 et 5 ans).

\section{Discussion}

Selon Kaufman (2010), l'environnement joue un rôle majeur dans le développement des FE, notamment en raison de la plasticité considérable du cerveau lors de la période de la petite enfance, qui réfère à la malléabilité des structures cérébrales, lesquelles disposent d'une grande capacité d'adaptation aux demandes de l'environnement (OCDE, 2007). C'est pourquoi Bransford, Brown et Cocking (2000) soulignent que le développement de l'enfant n'est pas seulement 《préprogrammé » par les gènes. Effectivement, l'expérience, notamment les relations affectives, y contribue également de façon importante, en modifiant les structures du cerveau. Dans le même ordre d'idées, Hoskyn et al. (2017) soulignent que le passage du temps ne permettrait pas, à lui seul, d'assurer le développement des habiletés associées aux FE. Il y a donc tout lieu de miser sur la qualité et la richesse des expériences vécues chez l'enfant d'âge préscolaire afin d'optimiser le développement de ses FE (Diamond, 2016). Il s'avère aussi nécessaire d'observer efficacement les habiletés associées aux FE et d'adapter ses pratiques enseignantes en fonction du développement de celles-ci.

En contexte de classe, plusieurs situations naturelles et quotidiennes proposées par l'adulte (p. ex. arrivée du matin, temps de jeu) permettent à l'enseignant d'observer les habiletés associées aux FE chez les enfants, lesquelles sont associées aux dimensions de son développement global. Par exemple, lors d'une causerie en grand groupe, un enfant qui parvient à écouter et à participer aux échanges peut démontrer qu'il est en mesure de respecter le tour de parole, d'être attentif aux propos partagés, d'organiser ses idées et d'adapter son discours. Ces habiletés sont respectivement associées à l'inhibition, à la mémoire de travail et à la flexibilité mentale, lesquelles lui permettent de se développer globalement. En effet, ces habiletés permettent à l'enfant de s'investir dans la causerie en partageant ses idées et ses intérêts (développement affectif), d'interagir avec ses pairs (développement social), de participer aux échanges et exprimer son point de vue (développement langagier), tout en demeurant concentré sur la visée de la discussion. Cela l'amènera à réfléchir et à planifier ses réponses en lien avec le sujet discuté (développement cognitif). Par ailleurs, il peut être difficile, pour un enfant de cet âge, d'attendre son tour de parole. L'enfant peut comprendre qu'il n'est pas approprié, sur le plan social, de couper la parole de ses pairs. Toutefois, il n'arrive pas nécessairement à mettre en application ce qu'il a compris, c'est-à-dire qu'il peut être conscient qu'un comportement n'est pas souhaité, sans pour autant être en mesure de le retenir.

Somme toute, cet exemple démontre que l'observation des différentes habiletés associées aux FE en contexte de classe permettrait à l'enseignant de mieux connaitre le profil développemental de chacun des enfants. L'observation contribue ainsi à la qualité du soutien offert par l'adulte, car elle permet à l'enseignant d'adapter ses interventions en fonction des besoins et des potentionnalités de chacun, tel qu'il les aura observés (p. ex. De quoi l'enfant est-il capable? Quels sont ses défis? Quel matériel est plus opportun pour le soutenir?).

\subsection{Quelques pistes d'observation et d'intervention à l'éducation préscolaire}

La section qui suit présente des pistes d'observation et d'intervention en milieu éducatif (c.-à-d. en fonction de la routine quotidienne de classe), et ce, en tissant des liens avec les propositions théoriques dégagées précédemment. De manière plus précise, le modèle théorique proposé par Miyake (2012) a été retenu en vue d'organiser les idées discutées ci-dessous. Il est donc suggéré d'observer différentes habiletés reliées à la mémoire de travail, l'inhibition et la flexibilité mentale dans le cadre de différentes situations d'apprentissage et de développement offertes en classe d'éducation préscolaire. Plus précisément, les jeux de tables, de cartes et de règles, les jeux de coopération et les jeux symboliques semblent être des occasions où l'adulte peut observer et soutenir différentes habiletés liées aux FE. Mentionnons que les pistes proposées ci-dessous, bien que basées sur les propositions théoriques présentées précédemment, sont des suggestions faites par les auteures.

\subsubsection{Jeux de table, de cartes et de règles}

En contexte d'éducation préscolaire, les enfants ont souvent l'occasion de réaliser des jeux de table. Lors de ce type de jeu, l'adulte peut observer différentes habiletés associées aux FE. Effectivement, les enfants doivent habituellement rester dans une posture assise et éviter de porter attention aux distractions de l'environnement qui les entoure. Il leur faut ensuite mémoriser et manipuler des informations d'ordre visuelles et auditives. Prenons un jeu de Cherche et Trouve : l'enfant devra d'abord mémoriser les règles du jeu, pour ensuite concentrer son attention sur les caractéristiques de l'objet à trouver en vue de les conserver en mémoire. Il devra ensuite faire abstraction d'un ensemble plus ou moins grand de stimuli visuels et tenter de retrouver le symbole qu'il a en tête. Dans cette situation, l'inhibition et la mémoire de travail sont sollicitées. Dans le cas où le jeu de Cherche et Trouve présente plusieurs planches différentes, l'enfant recherchera alors le même symbole dans plusieurs environnements différents. Autrement dit, il devra s'adapter et repérer le même symbole à un endroit différent. Cela fera appel à sa flexibilité mentale.

De façon similaire, l'enfant à qui l'on offre de participer à un jeu de mémoire sera alors invité à faire abstraction des stimuli qui l'entourent, afin de maintenir son attention sur les stimuli visuels qui lui sont présentés. Il devra par exemple mémoriser l'emplacement d'une image en vue de la retrouver et de l'associer à une carte présentant la même image. Dans cette situation, l'inhibition et la mémoire de travail s'avèrent des 
composantes sollicitées par l'enfant. De plus, ses capacités liées à la flexibilité mentale peuvent être mises à contribution, en expérimentant différentes stratégies en vue de résoudre des problèmes rencontrés pendant le jeu.

D'autres types de situations, telles que la réalisation d'un casse-tête ou la participation à un jeu de construction, demandent aussi à l'enfant de manipuler des objets afin de reproduire une image. Par conséquent, ce dernier doit garder en mémoire la représentation de ce qu'il souhaite reproduire. De façon similaire, il est possible d'observer des habiletés associées à la mémoire de travail lors de la reproduction de séries ou de séquences. Par exemple, lorsqu'un enfant s'investit dans un jeu nécessitant de dupliquer une frise ou d'enfiler des billes selon un ordre déterminé, il doit maintenir en mémoire différentes informations d'ordre visuel, en plus de les manipuler afin de reproduire un ensemble.

Finalement, de nombreux jeux proposent à l'enfant de diviser ou de catégoriser des cartes selon une couleur ou un symbole précis. Certains de ces jeux comprennent une opération (p. ex. diviser des cartes selon leur couleur), d'autres en comprennent plusieurs (p. ex. diviser les cartes selon leur couleur et la forme qui est représentée). Entre les âges de 3 et 4 ans, il semble plus difficile pour l'enfant de persévérer si la tâche demandée implique deux opérations (Best et Miller, 2010). En effet, si deux consignes sont données de façon simultanée, cela implique que l'enfant soit en mesure de maintenir la seconde consigne en mémoire pendant qu'il applique la première.

Au fur et à mesure que l'enfant grandit, la capacité à retenir deux règles simultanément devient plus facile, notamment lorsqu'il est soutenu par l'adulte dans les situations de jeu. De surcroit, dans plusieurs jeux de table, une nouvelle règle s'avère graduellement présentée à l'enfant, ce qui modifie le cours de la partie (p. ex. passer son tour, piger une ou des cartes supplémentaires, changer l'ordre dans lequel les joueurs sont invités à jouer, etc.). En plus d'exiger de l'enfant qu'il mémorise la signification des symboles, des règles et des objectifs du jeu, ce dernier est alors invité à s'adapter (flexibilité mentale).

Enfin, les faits relevés dans les paragraphes précédents démontrent qu'il est possible d'observer plusieurs habiletés associées aux FE à travers des jeux de table, de cartes et de règles. Mis à part ces types de jeu, les situations impliquant davantage d'interactions sociales, telles que le jeu coopératif, permettent également à l'adulte d'observer des habiletés liées aux FE chez l'enfant.

\subsubsection{Jeux coopératifs}

Lors d'un jeu de coopération, l'enfant est invité à mettre en œuvre plusieurs habiletés liées aux FE. Lors de ses interactions avec ses pairs, il doit d'abord prêter une attention soutenue à l'autre, en plus d'apprendre à considérer d'autres points de vue, à négocier et à faire des compromis (Hoskyn et al., 2017). Lorsque l'enfant devient en mesure de prêter un bon niveau d'attention à l'autre, il arrive alors à identifier l'état émotionnel dans lequel celui-ci se présente à lui. Il peut ensuite adapter son comportement en conséquence (Carlson et Wang, 2007).

Lorsqu'il vit des conflits avec ses pairs, l'enfant doit être en mesure de considérer la perspective de l'autre (flexibilité mentale), tout en l'écoutant et en inhibant ses réponses. Le fait de tenter de trouver une solution qui répondra aux besoins et aux envies des deux parties amène l'enfant à réguler ses émotions, ce qui lui permet de coopérer avec les autres. Ainsi, les jeux qui permettent la coopération seraient associés à différentes tâches reliées à l'inhibition et à la flexibilité mentale (Carlson et Wang, 2007). Afin d'amener l'enfant à coopérer avec ses pairs, plusieurs chercheurs suggèrent de miser sur des jeux qui lui permettent de s'investir dans des interactions sociales régulières (p. ex. jeux symboliques), lesquelles permettent de développer ses habiletés cognitives, telles que les FE (Goble et Pianta, 2017; Vygotski, 1978).

\subsubsection{Jeu symbolique}

Le jeu symbolique peut être défini comme une situation d'apprentissage et de développement où l'enfant crée une situation imaginaire, joue un rôle et suit des règles (Vygotski, 1978). L'enfant prend plaisir à s'y investir, par exemple, en se déguisant et en interprétant des personnages qui s'avèrent symboliques pour lui (p. ex. jouer à la maman/au papa). Lors de ce type de jeu, l'enfant est amené à inhiber certains comportements spontanés et en adopter de nouveaux en vue de faire progresser le scénario de jeu prévu.

Par exemple, l'enfant qui revêt le rôle de patient dans un scénario de clinique médicale devra contrôler ses envies d'utiliser le stéthoscope (matériel réservé au médecin) pour conserver son rôle et enrichir le scénario. En faisant appel à des habiletés liées à la mémoire de travail, il pourra se représenter mentalement le scénario proposé et le rôle qui lui est attribué, en l'associant aux éléments de sa propre vie. Par exemple, un enfant qui joue le rôle de commis d'épicerie lors d'un jeu symbolique pourra se baser sur les expériences qu'il a vécues au marché au courant de l'été. Finalement, au cours du jeu symbolique, l'enfant peut mettre en place des habiletés liées à la flexibilité mentale, en s'ajustant aux changements proposés par ses pairs (p. ex. l'épicerie prend en feu) et en modifiant rapidement sa représentation de la situation. Le jeu symbolique exige donc le déploiement de nombreuses habiletés reliées aux FE.

Moreno et al. (2016) suggèrent que d'observer les habiletés liées aux FE lors du jeu symbolique, qui s'avère signifiant pour l'enfant, permet de le situer dans sa zone proximale de développement (ZPD), soit de favoriser son plein potentiel en respectant ses besoins et son propre rythme d'apprentissage (Vygotski, 1997). Le jeu devient ainsi un contexte par excellence pour favoriser les FE de l'enfant d'âge préscolaire, d'autant plus que le contexte de groupe dans lequel évolue l'enfant lui permet de prendre plaisir à partager son monde imaginaire. 
Tel que vu précédemment, Vygotski (1997) a soutenu que la culture s'avère un produit de l'activité sociale chez l'humain et, pour cette raison, l'étude du comportement de l'enfant nous conduit directement vers le volet social de son développement. Par conséquent, Fleer, Veresov et Walker (2017), suggèrent que les FE devraient être considérées dans un contexte social, tel que dans un jeu symbolique qui implique plusieurs enfants, car il crée les conditions optimales pour soutenir le développement de l'enfant. De même, s'appuyant sur les travaux de Vygotski, Bodrova, Germeroth et Leong (2013) soulignent la pertinence d'examiner les habiletés associées aux FE à travers le jeu symbolique, notamment lorsqu'il est mature. En effet, il ne suffit pas d'offrir des situations de jeu symbolique en classe ; encore faut-il observer et étayer le jeu des enfants afin qu'il se complexifie et qu'il amène des gains chez ces derniers.

5.2 Le jeu symbolique mature: contexte clé pour le développement des $\mathrm{FE}$

En parallèle aux travaux de Vygotski, Elkonin (2005) a introduit le concept de jeu mature, qui constitue une forme d'activité unique pour l'enfant, notamment lorsqu'il est soutenu par l'adulte. Le jeu symbolique mature constituerait la forme la plus optimale pour favoriser les FE de l'enfant (Bodrova et Leong, 2007; Elkonin, 2005), car il l'amène à inventer des scénarios signifiants et complexes qui se rapprochent de sa réalité (Diamond, 2013). C'est pourquoi Blair et Raver (2014) soulignent que le jeu symbolique mature, planifié de manière intentionnelle, sert de véhicule pour développer les FE chez les enfants, de même que le langage, le vocabulaire et la créativité.

Selon Kelly et Hammond (2011), l'inhibition serait la première FE à émerger pendant l'âge préscolaire (3-6 ans), soit au même moment où le jeu symbolique est également à son apogée. En ce sens, Elias et Berk (2002) ont mené une étude longitudinale qui a montré que lorsque l'enfant s'engageait dans un jeu symbolique de haut niveau avec ses pairs au courant de l'année scolaire, il démontrait davantage d'habiletés d'inhibition à la fin de l'année, tel que mesurées par l'observation en contexte naturel lors de périodes de rangement. De manière plus précise, les enfants qui mettaient en œuvre des habiletés associées aux FE dans le cadre de leurs jeux symboliques étaient ensuite en mesure de les transférer dans d'autres situations de classe (p. ex. lors du rangement des ateliers).

Outre la capacité d'inhibition, on voit apparaitre, dans le jeu symbolique mature, des habiletés reliées à la mémoire de travail et à la flexibilité mentale (Diamond, 2013). Effectivement, dans ce contexte de jeu, l'enfant est amené à assumer et à maintenir un rôle spécifique en s'engageant constamment dans des actions y étant liées, en prenant part à des interactions qui correspondent à son personnage. Le jeu symbolique mature suppose également, pour des enfants de cet âge, la création de scénarios riches qui intègrent différents éléments familiers (p. ex. famille, transport), les amenant à puiser dans leur mémoire.
Ces différentes informations dévoilent que le jeu symbolique représente un contexte d'observation privilégié à l'éducation préscolaire. En effet, l'observation du jeu permet à l'adulte d'examiner le niveau d'habiletés des enfants pour ensuite les soutenir efficacement dans leur développement et leurs apprentissages, par exemple à l'aide de l'étayage. Concept provenant des travaux de Bruner (1983), l'étayage consiste à accompagner l'enfant pour l'amener de plus en plus loin dans son développement, en tenant compte de ses capacités actuelles et potentielles (Duval et Bouchard, 2013). Dans le cadre du jeu symbolique, cette forme d'accompagnement vise à guider l'enfant afin qu'il parvienne à un jeu de plus en plus mature, pour qu'il puisse développer ses habiletés associées aux FE de manière plus poussée (Bodrova et Leong, 2010). L'étayage permet ainsi à l'adulte de créer des conditions optimales pour la complexification du jeu. Par exemple, l'enseignant pourrait accompagner l'enfant en lui offrant suffisamment de temps pour développer un scénario de jeu de plus en plus évolué, il pourrait rendre accessible du matériel riche et diversifié, il pourrait prendre lui-même un rôle pour suggérer des nouvelles actions aux enfants, etc. (Trawick-Smith, 2012).

Pour que le jeu symbolique devienne une situation d'apprentissage et de développement riche et signifiante, les temps de jeu doivent être suffisamment longs et les enfants doivent pouvoir les planifier, afin de s'engager dans des rôles et des règles implicites (Landry, 2014). Hanline, Milton et Phelps (2010) ajoutent que la fréquence et la complexité du jeu symbolique sont des aspects importants à considérer dans le milieu éducatif, afin que l'enfant développe ses FE de manière efficace. Par exemple, le jeu devrait favoriser le dialogue, en plus d'intégrer l'utilisation d'accessoires symboliques (p. ex. un bloc de bois représentant un téléphone).

Enfin, selon l'approche vygotskienne, le rôle de l'adulte ne consiste pas à diriger le jeu de l'enfant, mais bien à le soutenir afin qu'il se complexifie et qu'il devienne mature. Les pratiques enseignantes déployées dans le cadre du jeu symbolique devraient permettre de bonifier la situation d'apprentissage et de développement dans laquelle l'enfant s'investit, l'amenant alors à développer ses habiletés cognitives liées aux FE.

\subsection{Optimiser le potentiel des stratégies d'observation et intervention}

Bien qu'il ait été démontré que la mise en place de différentes stratégies d'intervention permettrait de soutenir le développement des FE (Bodrova, 2008; Diamond et Lee, 2011), certaines conditions seraient essentielles afin d'optimiser ces dernières et d'en assurer l'efficacité (Bierman et Torres, 2016). Déjà en 1966, Luria soutenait que les fonctions psychologiques supérieures (c.-à-d. FE) sont d'abord développées grâce aux interactions entre l'enfant et les adultes qui l'entourent. Ces interactions permettent notamment à l'enfant de développer son langage, ce qui 
l'amène à modifier ses fonctions mentales, en plus de créer de nouvelles formes d'activité dans son esprit (Luria, 1966).

Selon Bodrova et Leong (2010), il importe de miser sur les temps de jeu permettant des interactions de qualité en classe (adulte-enfant et enfant-enfant), lesquelles favorisent le développement des FE. En ce sens, Moreno et al. (2016) ont récemment montré que les enfants faisaient davantage preuve d'habiletés liées aux FE (p. ex. mémoire de travail, inhibition) lorsque l'adulte interagissait avec eux, voire lorsqu'il les accompagnait dans le cadre de leurs jeux (p. ex. en prenant les traits d'un personnage, en les questionnant sur leurs stratégies, etc.).

De même, les enseignants qui s'engagent dans une activité quotidienne d'observation du jeu deviennent en mesure d'intervenir et d'étayer les situations d'apprentissages et de développement centrées sur l'enfant, et ce, de manière différenciée. Ils peuvent ainsi augmenter ou diminuer le soutien pédagogique offert aux enfants, selon leur rythme unique de développement et d'apprentissage. Cette manière d'intervenir permet à l'enfant de réfléchir à ses actions, en lui procurant un sentiment d'autocontrôle. Dans ce cadre, les activités proposées à l'enfant sont spécifiquement conçues pour inciter l'utilisation d'habiletés liées aux FE.

Plusieurs autres résultats de recherche (p. ex. Bernier et al., 2011; Duval et al., 2016; Fleer et al., 2017) suggèrent que par l'adoption de certaines attitudes (p. ex. sensibilité), l'adulte pourrait mettre en place un environnement propice à l'émergence des FE. En ce sens, il est d'abord suggéré de miser sur la qualité du soutien émotionnel dans le milieu éducatif (Curby et al., 2009). En effet, il semble que les enseignants qui interagissent de manière positive avec les enfants (p. ex. qui instaurent un climat positif, qui démontrent de la sensibilité à l'égard des enfants) sont ensuite en mesure de fournir un soutien de qualité dans leurs apprentissages. Duval et al. (2016) ont d'ailleurs montré que la qualité du soutien émotionnel offert en classe d'éducation préscolaire influençait les habiletés liées à la mémoire de travail et à l'inhibition chez l'enfant âgé de 5 ans.

De plus, les adultes qui organisent la classe en se souciant des besoins et des intérêts de l'enfant (p. ex. en variant les modalités d'apprentissage, en offrant du matériel riche et diversifié) lui permettent de s'investir dans des situations adaptées à son niveau de développement (Curby et al., 2009), pendant lesquelles il pourra mettre en place des habiletés liées aux FE. La structuration de l'horaire (p. ex. routines claires et prévisibles), de même que l'encadrement et la planification des situations proposées en classe inciteraient également l'enfant à explorer son environnement (Ibid.), ce qui favoriserait le développement de ses FE.

Enfin, la disponibilité, l'engagement et le support de l'enseignant seraient associés au niveau de persévérance de l'enfant dans les situations d'apprentissage et de développement suggérées. De manière plus précise, le soutien offert par l'adulte dans les situations d'apprentissage et de développement (p. ex. questionnement, étayage) amène l'enfant à réfléchir et à développer de nouveaux concepts à l'aide de rétroactions constructives et spécifiques (Curby et al., 2009), ce qui favorise en retour le développement des FE. La qualité des rétroactions consiste à se concentrer sur l'évolution de l'apprentissage et de la compréhension de l'enfant, au lieu de simplement indiquer si une réponse est correcte ou non (Franke, Kazemi et Battey, 2007). Les encouragements de l'enseignant permettent ainsi de soutenir le niveau d'engagement de l'enfant dans les situations d'apprentissage et de développement offertes, lequel serait lié au développement des $\mathrm{FE}$, favorisant par le fait même sa réussite éducative (Raver et al., 2008; Raver et al., 2011).

\section{Conclusion}

Cet article a d'abord permis de dégager les perspectives théoriques actuelles qui sont proposées afin de comprendre le développement des FE chez les enfants d'âge préscolaire. Rappelons que les conceptualisations des $\mathrm{FE}$ tendent à se situer selon deux grandes approches : 1) la perspective unitaire, mettant en évidence des composantes communes et indissociables des $\mathrm{FE}$; et 2) la perspective liée à des composantes différenciées et interreliées des FE (Knapp et Morton, 2017). Une perspective évolutive a été proposée quant au développement des FE durant la période préscolaire (3-6 ans). En effet, cet article a montré que la structure des FE se modifie progressivement au fil du développement, en raison des changements développementaux observés dans le cortex préfrontal du cerveau, et qu'il devient donc important d'envisager différentes manières de conceptualiser les FE en cours de développement (Ibid.), notamment à l'âge préscolaire.

Considérant ces faits, et soulignant l'intérêt actuel porté envers l'étude des FE, on peut se questionner sur les habiletés associées aux FE qui s'avèrent observables à l'éducation préscolaire, de manière à accompagner efficacement leur développement. Cet article suggère d'abord de mieux comprendre le développement des FE chez l'enfant d'âge préscolaire afin de dégager des pistes d'observation et d'intervention pour le personnel enseignant.

Selon Bierman et Torres (2016), certaines conditions s'avèrent essentielles afin d'optimiser le développement des FE en classe. Par exemple, il est proposé d'offrir des situations d'apprentissage et de développement misant sur les interactions sociales entre les enfants, ceci permettant le développement de différentes stratégies liées aux FE. Pour ce faire, il est reconnu que les pratiques enseignantes centrées sur l'enfant et sur l'apprentissage par le jeu (p. ex. jeu symbolique mature) lui permettent d'apprendre et de se développer à son plein potentiel pendant la période préscolaire (Bodrova et Leong, 2010 ; Diamond, 2009; Fleer et al., 2017; Moreno et al., 2016). 


\section{Références}

Anderson, V., Jacobs, R. et Anderson, P. (dir.). (2008). Executive functions and the frontal lobes: A lifespan perspective. New York, NY: Taylor \& Francis. https://doi.org/10.4324/9780203837863

Bear, M. F., Connors, B. W. et Paradiso, M. (2016). Neurosciences : À la découverte du cerveau (4 éd.). Paris, France: Pradel.

Bernier, A., Carlson, S. M., Deschênes, M. et Matte-Gagné, C. (2011). Social factors in the development of early executive functioning: a closer look at the caregiving environment. Developmental Science, 15(1), 12-24. https://doi.org/10.1111/j.1467-7687.2011.01093.x

Best, J. R. et Miller, P. H. (2010). A developmental perspective on executive function. Child Development, 81(6), 16411660. https://doi.org/10.1111/j.1467-8624.2010.01499.x

Best, J. R., Miller, P. H. et Jones, L. L. (2009). Executive functions after age 5: Changes and correlates. Developmental Review, 29(3), 180-200. https://doi.org/10.1016/j.dr.2009.05.002

Bierman, K. L. et Torres, M. (2016). Promoting the development of executive functions through early education and prevention programs. Dans J. A. Griffin, P. McCardle et L. S. Freund (dir.), Executive function in preschool-age children: Integrating measurement, neurodevelopment, and translational research (p. 299326). Washington, DC: American Psychological Association. https://doi.org/10.1037/14797-014

Blair, C. B. et Raver, C. C. (2014). Closing the achievement gap through modification of neurocognitive and neuroendocrine function: Results from a cluster randomized controlled trial of an innovative approach to the education of children in kindergarten. PLoS ONE, 9(11), e112393. https://doi.org/10.1371/journal.pone.0112393

Blair, C. B. et Razza, R. P. (2007). Relating effortful control, executive function, and false belief understanding to emerging math and literacy ability in kindergarten. Child Development, 78(2), 647-663.

https://doi.org/10.1111/j.1467-8624.2007.01019.x

Bodrova, E. (2008). Make-believe play versus academic skills: A Vygotskian approach to dilemma of early childhood education. European Early Childhood Education Research Journal, 16(3), 357-369. https://doi.org/10.1080/13502930802291777

Bodrova, E., Germeroth, C. et Leong, D. J. (2013). Play and selfregulation: Lessons from Vygotsky. American Journal of Play, 6(1), 111-123.

http://www.journalofplay.org/issues/6/1/article/7play-and-self-regulation-lessons-vygotsky
Bodrova, E. et Leong, D. J. (2010). Revisiting vygotskian perspectives of play and pedagogy. Dans S. Rogers (dir.), Rethinking play and pedagogy in early childhood education. Concepts, contexts and cultures (p. 60-72). New York, NY: Routledge. http://doi.org/10.4324/9780203839478

Bodrova, E. et Leong, D. J. (2007). Tools of the mind: The Vygotskian approach to early childhood education ( $2^{\mathrm{e}}$ éd.). Columbus, $\mathrm{OH}$ : Merrill/Prentice Hall.

Bouchard, C. (2012). Le développement global de l'enfant, au cœur de l'éducation au préscolaire! Revue Préscolaire, 50(2), 9-14.

https://www.aepq.ca/wpcontent/uploads/2011/04/AEPQ_Revue_v50n2.pdf

Bouchard, C. et Fréchette, N. (2008). Le développement global de l'enfant de 0 à 5 ans en contextes éducatifs. Québec, Canada: Presses de l'Université du Québec.

Bransford, J. D., Brown, A. L. et Cocking, R. R. (2000). How people learn. Washington, DC: National Academy Press. https://doi.org/10.17226/9853

Bruner, J. (1983). Child's talk: Learning to use language. New York, NY: Norton.

Bull, R., Espy, K. A. et Wiebe, S. A. (2008). Short-term memory, working memory, and executive functioning in preschoolers: Longitudinal predictors of mathematical achievement at age 7 years. Developmental Neuropsychology, 33(3), 205-228. https://doi.org/10.1080/87565640801982312

Carlson, S. M., Mandell, D. J. et Williams, L. (2004). Executive function and theory of mind: Stability and prediction from ages 2 to 3. Developmental Psychology, 40(6), 11051122. https://doi.org/10.1037/0012-1649.40.6.1105

Carlson, S. M. et Wang, T. S. (2007). Inhibitory control and emotion regulation in preschool children. Cognitive Development, 22(4), 489-510. https://doi.org/10.1016/j.cogdev.2007.08.002

Chevalier, N. (2010). Les fonctions exécutives chez l'enfant: Concepts et développement. Canadian Psychology, 51(3), 149-163. https://doi.org/10.1037/a0020031

Clark, C. A. C., Pritchard, V. E. et Woodward, L. J. (2010). Preschool executive functioning abilities predict early mathematics achievement Developmental Psychology, 46(5), 1176-1191. https://doi.org/10.1037/a0019672

Clark, C. A. C., Sheffield, T. D., Chevalier, N., Nelson, J. M., Wiebe, S. A. et Espy, K. A. (2013). Charting early trajectories of executive control with the shape school. Developmental Psychology, 49(8), 1481-1493. https://doi.org/10.1037/a0030578 
Curby, T. W., LoCasale-Crouch, J., Konold, T. R., Pianta, R. C., Howes, C., Burchinal, ... et Barbarin, O. (2009). The relations of observed pre-K classroom quality profiles to children's achievement and social competence. Early Education and Development, 20(2), 346-372. https://doi.org/10.1080/10409280802581284

Dekker, M. C., Ziermans, T. B. et Swaab, H. (2016). The impact of behavioural executive functioning and intelligence on math abilities in children with intellectual disabilities. Journal of Intellectual Disability Research, 60(11), 10861096. https://doi.org/10.1111/jir.12276

De Luca, C. R. et Leventer, R. J. (2008). Developmental trajectories of executive functions across the lifespan. Dans V. Anderson, R. Jacobs et P. J. Anderson (dir.), Executive functions and the frontal lobes: A lifespan perspective (p. 57-90). New York, NY: Taylor \& Francis. http://doi.org/10.4324/9780203837863

Denckla, M. B. (1996) A theory and model of executive function: A neuropsychological perspective. Dans G. R Lyon et N. A. Krasnegor (dir.), Attention, memory and executive function (p. 263-278). Baltimore: Paul $\mathrm{H}$ Brookes Publishing.

Dennis, M. (2006). Prefrontal cortex: Typical and atypical development. Dans J. Risberg et J. Grafman (dir.), The frontal lobes: Development, function and pathology (p. 128162). New York, NY : Cambridge University Press. https://doi.org/10.1017/cbo9780511545917.007

Diamond, A. (2016). Why improving and assessing executive functions early in life is critical. Dans J. A. Griffin, P. McCardle et L. S. Freund (dir.), Executive function in preschool-age children: Integrating measurement, neurodevelopment, and translational research (p. 11-43). Washington, DC: American Psychological Association. https://doi.org/10.1037/14797-002

Diamond, A. (2013). Executive functions. Annual Review of Psychology, 64(1), 135-168.

https://doi.org/10.1146/annurev-psych-113011-143750

Diamond, A. (2009). Apprendre à apprendre. Les Dossiers de La Recherche, (34), 89-92.

Diamond, A. (2006). The early development of executive functions. Dans E. Bialystok et F. Craik (dir.), Lifespan cognition: Mechanisms of change (p. 70-95). New York, NY: Oxford University Press.

https://doi.org/10.1093/acprof:oso/9780195169539.00 $\underline{3.0006}$

Diamond, A. (2002). Normal development of prefrontal cortex from birth to young adulthood: Cognitive functions, anatomy, and biochemistry. Dans D. T. Stuss et R. T. Knight (dir.), Principles of frontal lobe function (p. 466503). Londres, Royaume-Uni : Oxford University Press. https://doi.org/10.1093/acprof:oso/9780195134971.003.0029
Diamond, A. et Lee, K. (2011). Interventions shown to aid executive function development in children 4 to 12 years old. Science, 333(6045), 959-964.

https://doi.org/10.1126/science.1204529

Duval, S. et Bouchard, C. (2013). Soutenir la préparation à l'école et à la vie des enfants issus de milieux défavorisés et des enfants en difficulté. Document préparé pour le ministère de la Famille. Québec, Canada : Gouvernement du Québec.

https://www.mfa.gouv.qc.ca/fr/publication/documen ts/preparation-ecole.pdf

Duval, S., Bouchard, C., Pagé, P. et Hamel, C. (2016). Quality of classroom interactions in kindergarten and executive functions among five-year-old children. Cogent Education, 3(1), 1-18. https://doi.org/10.1080/2331186x.2016.1207909

Elias, C. L. et Berk, L. E. (2002). Self-regulation in young children: Is there a role for sociodramatic play? Early Childhood Research Quarterly, 17(2), 216-238. https://doi.org/10.1016/S0885-2006(02)00146-1

Elkonin, D. B. (2005). Chapter 1: The Subject of Our Research: The Developed Form of Play. Journal of Russian $\&$ East European Psychology, 43(1), 22-48.

https://www.tandfonline.com/doi/abs/10.1080/10610 $\underline{405.2005 .11059242}$

Engel de Abreu, P. M. J., Abreu, N., Nikaedo, C. C., Puglisi, M. L., Tourinho, C. J., Miranda, M. C., ... et Martin, R. (2014). Executive functioning and reading achievement in school: A study of Brazilian children assessed by their teachers as "poor readers". Frontiers in Psychology, 5, 550. https://doi.org/10.3389/fpsyg.2014.00550

Engelhardt, L. E., Briley, D. A., Mann, F. D., Harden, K. P. et Tucker-Drob, E. M. (2015). Genes unite executive functions in childhood. Psychological Science, 26(8), 11511163. https://doi.org/10.1177/0956797615577209

Fleer, M., Veresov, N. et Walker, S. (2017). Re-conceptualizing executive functions as social activity in children's playworlds. Learning, Culture and Social Interaction, 14, 1-11. https://doi.org/10.1016/j.lcsi.2017.04.003

Fortin, C. et Rousseau, R. (2012). Psychologie cognitive. Une approche de traitement de l'information. Québec, QC: Presses de l'Université du Québec.

Foy, J. G. et Mann, V. A. (2012). Executive function and early reading skills. Reading and Writing, 26(3) 453-472. https://doi.org/10.1007/s11145-012-9376-5

Franke, M. L., Kazemi, E. et Battey, D. (2007). Mathematics teaching and classroom practice. Dans F. K. Lester (dir.), Second handbook of research on mathematics teaching and learning (p. 225-256). Charlotte, NC: Information Age. 
Friedman, N. P. et Miyake, A. (2004). The relations among inhibition and interference control functions: A latentvariable analysis. Journal of Experimental Psychology: General, 133(1), 101-135. https://doi.org/10.1037/0096$\underline{3445.133 .1 .101}$

Fuhs, M. W. et Day, J. D. (2011). Verbal ability and executive functioning development in preschoolers at head start. Developmental Psychology, 47(2), 404-416. https://doi.org/10.1037/a0021065

Fuhs, M. W., Farran, D. C. et Nesbitt, K. T. (2013). Preschool classroom processes as predictors of children's cognitive self-regulation skills development. School Psychology Quarterly, 28(4), 347-359.

https://doi.org/10.1037/spq0000031

Fujisawa, K. K., Todo, N. et Ando, J. (2016). Genetic and environmental influences on the development and stability of executive functions in children of preschool age: A longitudinal study of Japanese twins. Infant and Child Development, 26(3), e1994. https://doi.org/10.1002/icd.1994

Garon, N., Bryson, S. E. et Smith, I. M. (2008). Executive function in preschoolers: A review using an integrative framework. Psychological Bulletin, 134(1), 31-60. https://doi.org/10.1037/0033-2909.134.1.31

Garon, N., Smith, I. M. et Bryson, S. E. (2013). A novel executive function battery for preschoolers: Sensitivity to age differences. Child Neuropsychology, 20(6), 713-736. https://doi.org/10.1080/09297049.2013.857650

Goble, P. et Pianta, R. C. (2017). Teacher-child interactions in free choice and teacher-directed activity settings: Prediction to school readiness. Early Education and Development, 28(8),1035-1051.

https://doi.org/10.1080/10409289.2017.1322449

Hanline, M. F., Milton, S. et Phelps, P. C. (2010). The relationship between preschool block play and reading and maths abilities in early elementary school: A longitudinal study of children with and without disabilities. Early Child Development and Care, 180(8), 1005-1017. https://doi.org/10.1080/03004430802671171

Hirsh-Pasek, K., Golinkoff, R. M., Berk, L. et Singer, D. (2008). A mandate for playful learning in preschool: Presenting the evidence. New York, NY : Oxford University Press. https://doi.org/10.1093/acprof:oso/9780195382716.001 .0001

Holmes-Bernstein, J. et Waber, D. P. (1990) Developmental neuropsychological assessment: The systemic approach. Dans A. A. Boulton, G. B. Baker et M. Hiscock (dir.), Neuromethods (vol. 17, p. 311-371). Totowa, NJ : Humana Press. https://doi.org/10.1385/0896031330
Hoskyn, M. J., Iarocci, G. et Young, A. R. (dir.). (2017). Executive functions in children's everyday lives: A handbook for professionals in applied psychology. New York, NY: Oxford University Press.

https://doi.org/10.1093/acprof:oso/9780199980864.0 01.0001

Hughes, C., Ensor, R., Wilson, A. et Graham, A. (2009). Tracking executive function across the transition to school: A latent variable approach. Developmental Neuropsychology, 35(1), 20-36. https://doi.org/10.1080/87565640903325691

Huizinga, M., Dolan, C. V. et van der Molen, M. W. (2006). Agerelated change in executive function: Developmental trends and a latent variable analysis. Neuropsychologia, 44(11), 2017-2036. https://doi.org/10.1016/j.neuropsychologia.2006.01.010

Isquith, P. K., Gioia, G. A. et Espy K. A. (2004). Executive function in preschool children: Examination through everyday behavior. Developmental Neuropsychology, 26(1), 403-422. https://doi.org/10.1207/s15326942dn2601_3

Jacob, R. et Parkinson, J. (2015). The potential for schoolbased interventions that target executive function to improve academic achievement: A review. Review of Educational Research, 85(4), 512-552. https://doi.org/10.3102/0034654314561338

Johansson, M., Marciszko, C., Brocki, K. et Bohlin, G. (2015). Individual differences in early executive functions: A longitudinal study from 12 to 36 months. Infant and Child Development, 25(6), 533-549. https://doi.org/10.1002/icd.1952

Kagan, J. et Baird, A. (2004). Brain and behavioral development during childhood. Dans M. S. Gazzaniga (dir.), The cognitive neurosciences (p. 93-103). Cambridge, MA: MIT Press.

Kaufman, C. (2010). Executive function in the classroom: Practical strategies for improving performance and enhancing skills for all students. Baltimore, MA: Brookes Publishing.

Kelly. R. et Hammond, S. (2011). The relationship between symbolic play and executive function in young children. Australasian Journal of Early Childhood, 36, 21-27.

Knapp, K. et Morton, J. B. (2017). Executive functioning: A developmental cognitive neuroscience perspective. Dans M. J. Hoskyn, G. Iarocci et A. R. Young (dir.), Executive functions in children's everyday lives: A handbook for professionals in applied psychology (p. 9-20). New York, NY : Oxford University Press.

https://doi.org/10.1093/acprof:oso/9780199980864.0 $\underline{03.0002}$ 
Kroesbergen, E. H., Van Luit, J., Van Lieshout, E., Van Loosbroek, E. et Van de Rijt, B. (2009). Individual differences in early numeracy: The role of executive functions and subitizing. Journal of Psychoeducational Assessment, 27(3), 226-236. https://doi.org/10.1177/0734282908330586

Landry, S. (2014). Favoriser le développement de la pensée sociale par l'étayage du jeu symbolique chez des enfants qui fréquentent la maternelle cinq ans. Thèse de doctorat inédite. Université Laval, Québec, Canada. http://hdl.handle.net/20.500.11794/24789

Lee, K., Bull, R. et Ho, R. M. H. (2013). Developmental changes in executive functioning. Child Development, 84(6), 19331953. https://doi.org/10.1111/cdev.12096

Lehto, J. E., Juujärvi, P., Kooistra, L. et Pulkkinen, L. (2003). Dimensions of executive functioning: Evidence from children. British Journal of Developmental Psychology, 21(1), 59-80. https://doi.org/10.1348/026151003321164627

Lenroot, R. K. et Giedd, J. N. (2006). Brain development in children and adolescents: Insights from anatomical magnetic resonance imaging. Neuroscience $\varepsilon$ Biobehavioral Reviews, 30(6), 718-729.

https://doi.org/10.1016/j.neubiorev.2006.06.001

Luria, A. R. (1966). Higher cortical functions in man. Oxford, Royaume-Uni : Basic Books.

Mann, T. D., Hund, A. M., Hesson-McInnis, M. S. et Roman, Z. J. (2016). Pathways to school readiness: Executive functioning predicts academic and social-emotional aspects of school readiness. Mind, Brain, and Education, 11(1), 21-31. https://doi.org/10.1111/mbe.12134

Miller, M. R., Giesbrecht, G. F., Müller, U., McInerney, R. J. et Kerns, K. A. (2012). A latent variable approach to determining the structure of executive function in preschool children. Journal of Cognition and Development, 13(3), 395-423.

https://doi.org/10.1080/15248372.2011.585478

Ministère de l'Éducation du Québec (MEQ). (2006). Programme de formation de l'école québécoise. Québec, QC: Gouvernement du Québec.

Ministère de la Famille du Québec (MFA). (2007). Accueillir la petite enfance. Québec: QC: Gouvernement du Québec.

Miyake, A. et Friedman, N. P. (2012). The nature and organization of individual differences in executive functions: Four general conclusions. Current Directions in Psychological Science, 21(1), 8-14.

https://doi.org/10.1177/0963721411429458

Miyake, A., Friedman, N. P., Emerson, M. J., Witzki, A. H., Howerter, A. et Wager, T. D. (2000). The unity and diversity of executive functions and their contributions to complex "frontal lobe" tasks: A latent variable analysis. Cognitive Psychology, 41(1), 49-100.

https://doi.org/10.1006/cogp.1999.0734
Monette, S., Bigras, M. et Lafrenière, M.-A. (2015). Structure of executive functions in typically developing kindergarteners. Journal of Experimental Child Psychology, 140, 120-139. https://doi.org/10.1016/j.jecp.2015.07.005

Moreno, A. J., Shwayder, I. et Friedman, I. D. (2016). The function of executive function: Everyday manifestations of regulated thinking in preschool settings. Early Childhood Education Journal, 45(2), 143-153. https://doi.org/10.1007/s10643-016-0777-y

Organisation de coopération et de développement économiques (OCDE) (2007). Comprendre le cerveau: Naissance d'une science de l'apprentissage. Paris, France: Éditions OCDE. https://doi.org/10.1787/9789264029156-fr

Pellegrini, A. D. (2009). The role of play in human development. New York, NY : Oxford University Press. https://doi.org/10.1093/acprof:oso/9780195367324.00 $\underline{1.0001}$

Raver, C. C., Blair, C. B. et Willoughby, M. (2013). Poverty as a predictor of 4-year-olds' executive function: New perspectives on models of differential susceptibility. Developmental Psychology, 49(2), 292-304. https://doi.org/10.1037/a0028343

Raver, C. C., Jones, S. M., Li-Grining, C. P., Metzger, M., Champion, K. M. et Sardin, L. (2008). Improving preschool classroom processes: Preliminary findings from a randomized trial implemented in Head Start settings. Early Childhood Research Quarterly, 23(1), 10-26. https://doi.org/10.1016/j.ecresq.2007.09.001

Raver, C. C., Jones, S. M., Li-Grining, C., Zhai, F., Bub, K. et Pressler, E. (2011). CSRP's impact on low-income preschoolers' preacademic skills: Self-regulation as a mediating mechanism. Child Development, 82(1), 362-378. https://doi.org/10.1111/j.1467-8624.2010.01561.x

Rhoades, B. L., Greenberg, M. T., Lanza, S. T. et Blair, C. B. (2011). Demographic and familial predictors of early executive function development: Contribution of a person-centered perspective. Journal of Experimental Child Psychology, 108(3), 638-662. https://doi.org/10.1016/j.jecp.2010.08.004

Roebers, C. M. (2017). Executive function and metacognition: Towards a unifying framework of cognitive selfregulation. Developmental Review, 45, 31-51. https://doi.org/10.1016/j.dr.2017.04.001

Röthlisberger, M., Neuenschwander, R., Cimeli, P., Michel, E. et Roebers, C. M. (2011). Improving executive functions in 5- and 6-year-olds: Evaluation of a small group intervention in prekindergarten and kindergarten children. Infant and Child Development, 21(4), 411-429. https://doi.org/10.1002/icd.752

Roy, A. (2012). Les fonctions exécutives chez l'enfant: Approche épistémologique et sémiologique clinique. Revue de neuropsychologie, 4(4), 287-297. https://doi.org/10.3917/rne.044.0287 
Shing, Y. L., Lindenberger, U., Diamond, A., Li, S.-C. et Davidson, M. C. (2010). Memory maintenance and inhibitory control differentiate from early childhood to adolescence. Developmental Neuropsychology, 35(6), 679697. https://doi.org/10.1080/87565641.2010.508546

Simard, M., Tremblay, M.-E., Lavoie, A. et Audet, N. (2013). Enquête québécoise sur le développement des enfants à la maternelle 2012. Portrait statistique pour le Québec et ses régions administratives. Québec, Canada: Institut de la statistique du Québec.

http://www.stat.gouv.qc.ca/statistiques/sante/enfant s-ados/developpement-enfants-maternelle-2012.pdf

Skogan, A. H., Egeland, J., Zeiner, P., Øvergaard, K. R., Oerbeck, B., Reichborn-Kjennerud, T. et Aase, H. (2015). Factor structure of the Behavior Rating Inventory of Executive Functions (BRIEF-P) at age three years. Child Neuropsychology, 22(4), 472-492. https://doi.org/10.1080/09297049.2014.992401

Trawick-Smith, J. (2012). Teacher-child play interactions to achieve learning outcomes. Risks and opportunities. Dans R. C. Pianta (dir.), Handbook of early childhood education (p. 259-277). New York, NY : Guilford Press.

Usai, M. C., Viterbori, P., Traverso, L. et De Franchis, V. (2013). Latent structure of executive function in five- and sixyear-old children: A longitudinal study. European Journal of Developmental Psychology, 11(4), 447-462.

https://doi.org/10.1080/17405629.2013.840578

van der Ven, S. H. G., Kroesbergen, E. H., Boom, J. et Leseman, P. P. M. (2012). The structure of executive functions in children: A closer examination of inhibition, shifting, and updating. British Journal of Developmental Psychology, 31(1), 70-87. https://doi.org/10.1111/j.2044-835X.2012.02079.x

Vocate, D. R. (1987). The theory of A.R. Luria: Functions of spoken language in the development of higher mental processes. Hillsdale, MI: Erlbaum.

Vygotski, L. S. (1997). Pensée et langage (3e éd.). Paris, France: La Dispute.
Vygotsky, L. S. (1978). The role of play in development. Dans L. S. Vygotsky (dir.), Mind in society. The development of higher psychological processes (p. 92-104). Cambridge, MA : Harvard University Press.

Wiebe, S. A., Espy, K. A. et Charak, D. (2008). Using confirmatory factor analysis to understand executive control in preschool children: I. Latent structure. Developmental Psychology, 44(2), 575-587. https://doi.org/10.1037/0012-1649.44.2.575

Wiebe, S. A., Sheffield, T., Nelson, J. M., Clark, C. A. C., Chevalier, N. et Espy, K. A. (2011). The structure of executive function in 3-year-olds. Journal of Experimental Child Psychology, 108(3), 436-452. https://doi.org/10.1016/j.jecp.2010.08.008

Williford, A. P., Vick Whittaker, J. E., Vitiello, V. E. et Downer, J. T. (2013). Children's engagement within the preschool classroom and their development of self-regulation. Early Education \& Development, 24(2), 162-187. http://dx.doi.org/10.1080/10409289.2011.628270

Willoughby, M. T., Blair, C. B., Wirth, R. J. et Greenberg, M. (2010). The measurement of executive function at age 3 years: Psychometric properties and criterion validity of a new battery of tasks. Psychological Assessment, 22(2), 306-317. https://doi.org/10.1037/a0018708

Willoughby, M. T., Wirth, R. J. et Blair, C. B. (2012). Executive function in early childhood: Longitudinal measurement invariance and developmental change. Psychological Assessment, 24(2), 418-431. https://doi.org/10.1037/a0025779

Zelazo, P. D. (2013). The Oxford handbook of developmental psychology (vol.1). New York, NY : Oxford University Press. https://doi.org/10.1093/oxfordhb/9780199958450.001.0001

Zelazo, P. D. et Müller, U.(2010). Executive function in typical and atypical development. Dans U. Goswami (dir.), The WileyBlackwell handbook of childhood cognitive development (p. 574-603). Cambridge, Royaume-Uni : Wiley-Blackwell. https://doi.org/10.1002/9781444325485.ch22 


\title{
Proportional reasoning: Reducing the interference of natural numbers through an intervention based on the problem-solving framework of executive functions
}

\author{
Reuven Babai ${ }^{1,2^{\star}}$, Eldad Cohen ${ }^{1}$, Ruth Stavy ${ }^{1,2}$
}

\begin{abstract}
According to the problem-solving framework of executive functions, the first step is to construct a problem space, i.e., the representation of the problem and its possible solutions. We explored how different problem spaces affect students' proportional reasoning. Proportional reasoning is important in school and in everyday life. It involves the comparison of ratios and is known to be difficult. Previous studies have shown that difficulties in proportional reasoning may stem from the interference of the automatic comparison of the salient natural numbers that comprise the ratios. We designed two equivalent comparison of ratios tests that were visually very similar, the Drops test and the Juice test. In the Drops test, tenth graders were asked to compare the intensity of color of mixtures of red and white paint drops. In the Juice test, they were asked to compare the amount of juice each child receives when equally dividing the contents of cups of juice among children in each group. The Juice test was aimed at presenting the task in a mode leading to a problem space that directs students to calculate "rate per unit," thereby reducing the interference of the automatic comparison of the salient natural numbers. The findings indicated that success in the Juice test was higher than in the Drops test. Moreover, success in the Drops test was higher when performed after the Juice test. The current study suggests using modes of presentation that lead to problem spaces that direct students to use appropriate solution strategies, hence aiding them in overcoming difficulties. Using modes or orders of presentation could serve as important tools for educators in science and mathematics and could lead to higher academic achievements among their students.
\end{abstract}

\footnotetext{
${ }^{1}$ Tel Aviv University, The Constantiner School of Education, Department of Mathematics, Science and Technology Education, Tel Aviv, Israel

${ }^{2}$ Tel Aviv University, The Sagol School of Neuroscience, Tel Aviv, Israel

* Author email address: reuvenb@post.tau.ac.il
}

To cite this article: Babai, R., Cohen, E., \& Stavy, R. (2018). Proportional reasoning: Reducing the interference of natural numbers through an intervention based on the problem-solving framework of executive functions. Neuroeducation, 5(2), 109-118.

DOI: https://doi.org/10.24046/neuroed.20180502.109

Received on November $24^{\text {th }}$, 2017. Received in revised form on April $28^{\text {th }}, 2018$.

Accepted on May $10^{\text {th }}, 2018$. Available online on September $19^{\text {th }}, 2018$.

Neuroeducation, 5(2), 109-118

ISSN: 1929-1833

All rights reserved (C) 2018 - Association for Research in Neuroeducation 


\section{Introduction}

Executive functions play a significant role in problem solving. The problem-solving framework of executive functions identifies four temporally distinct phases (Zelazo et al., 1997): representation, planning, execution, and evaluation. The first step in solving a problem is constructing a problem space. The problem space is the representation of the problem and its possible solutions. Studies in science and mathematics education have shown that students' performance is affected by the way in which problems are presented (e.g., Clement, 1993; Elia, Gagatsis, \& Demetriou, 2007; Martin \& Schwartz, 2014; Stavy \& Berkovitz, 1980; Tirosh \& Tsamir, 1996; Tsamir, 2003).

Stavy (1991) studied conservation of matter by students, for example, using two presentation modes, showing that students correctly conserved weight when a colorful gas (iodine) was evaporated in a closed test tube but not when a colorless gas (acetone) was used (58 \% vs. $13 \%$ ). It seems that when iodine was evaporated the created problem space supported students' appropriate solution strategies. These findings raised the possibility of improving students' performance in the colorless gas (acetone) conservation of weight task by first presenting the colorful gas (iodine) conservation of weight task, which supports appropriate solution strategies. Indeed, performance in the acetone conservation of weight task was found to be significantly higher $(44 \%)$ when it followed the iodine conservation of weight task.

Performance in the comparison of perimeters task in two modes of presentation was recently explored (Babai, Nattiv, \& Stavy, 2016). In the comparison of perimeters task it was previously shown that the irrelevant salient variable area interferes with students' reasoning about the relevant variable, perimeter. In one mode of presentation, the perimeters of the geometrical shapes were drawn continuously (continuous mode of presentation). In the other mode they were drawn as built from separate units, matchsticks (discrete mode of presentation). It was found that success in the discrete mode of presentation was higher than in the continuous mode. Moreover, success in the continuous mode increased as a result of previously performing the task in the discrete mode. It was suggested that the problem space created by the discrete mode of presentation led students to appropriate solution strategies, such as moving of segments and/or counting them. The study indicated that altering the mode or order of presentation could serve as an educational tool that might improve students' performance. The current study focuses on a comparison of ratios task, known to be difficult for many students. We presented the task using two modes of presentation that lead to different problem spaces and hence to different solution strategies. We ask whether the mode of presentation affects students' performance in comparing ratios. Previous research has found that in comparison of ratios, much like in the comparison of perimeters, salient variables interfered with students' reasoning.
Proportional reasoning is the ability to compare quantities multiplicatively using ratios and numerical constructs such as fractions. It involves the use of ratios in the comparison of quantities and requires the understanding of direct and inverse relations. It is needed in many science disciplines, when calculating, for example, concentrations, probabilities, densities, velocities, and currents, and is used in mathematics for geometry and algebra. Finally, everyday life financial and purchasing decisions require its use.

Research has shown that proportional reasoning is difficult for many students and adults (e.g., Gómez et al., 2015; Inhelder \& Piaget, 1958; Karplus, Pulos, \& Stage 1983; Lamon, 2007; Moss \& Case, 1999; Ni \& Zhou, 2005; Noelting, 1980a, 1980b; Reiss et al., 1985; Siegler, 1976). The following example demonstrates a common difficulty associated with comparison of ratios. Adolescents were presented with two boxes (Box A containing 3 black balls and 1 white ball, and Box B containing 6 black balls and 2 white balls) and asked to decide if they were more likely to pick a black ball from one of the two boxes, without looking, or if the chance was equal (Green, 1983). The most common response was incorrect, Box B. According to Stavy and Tirosh (2000), this response reflects interference of the salient number of black balls, with formal/logical reasoning. The findings suggest that participants compare the number of black balls in each box instead of calculating the ratios between the number of black and white balls. Comparison of numbers is known as an automatic intuitive process (e.g., Dehaene, 2011). It should be noted that such interference of natural numbers was also observed when using symbolic notations of ratios (like fractions) in several behavioral (Bonato et al., 2007; Kallai \& Tzelgov, 2009; Meert, Grégoire, \& Noël, 2009; Vamvakoussi, Van Dooren, \& Verschaffel, 2012) and brain-imaging studies (Ischebeck, Schocke, \& Delazer, 2009; Stavy, Babai, \& Kallai, 2016).

In general, Fischbein (1987) who studied the role of intuition in science and mathematics claimed that some of students' erroneous responses could arise from intuitive reasoning. Recently, it has been suggested that students' difficulties in science and mathematics could stem from the interference of salient (intuitively, automatically processed) irrelevant variables with formal/logical reasoning (e.g., Stavy \& Babai, 2008, 2010). Apparently, certain variables of the task are so salient that they are automatically processed and thus interfere with correct reasoning.

To explore intuitive interference in comparison of ratios, a nonsymbolic reaction time comparison of probabilities task that included congruent and incongruent trials (see Figure 1) was designed (Babai et al., 2006). In congruent trials there was no intuitive interference, as one box had a larger number of black balls and a higher probability of picking a black ball. In incongruent trials there was interference, as one box had a larger number of black balls, but a lower probability of picking a black ball. 


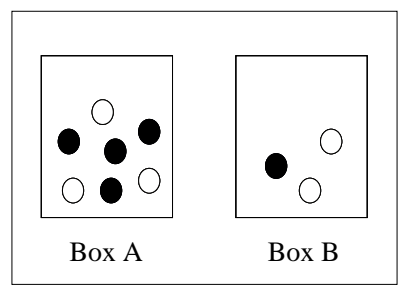

Congruent

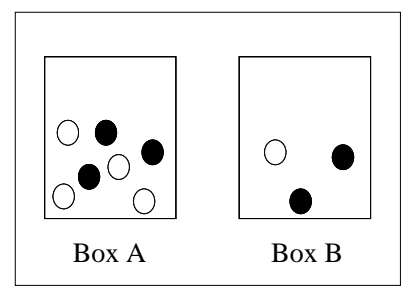

Incongruent
Figure 1. Examples of congruent and incongruent comparison of probabilities task trials

Findings showed that high school students' accuracy of responses in congruent trials was significantly higher than in incongruent ones. Reaction time of correct responses (RTC) in congruent trials was significantly shorter than in incongruent ones (Babai et al., 2006). It was suggested that when the automatic comparison of the number of black balls and that of the probability of picking a black ball resulted in the same conclusion as in congruent trials, students answered correctly and quickly. When the outcome was two different conclusions, a conflict was created. Resolving this conflict was found to be a demanding and a time-consuming process.

Recently, comparison of ratios was studied using reaction time methodology and fMRI brain-imaging (Stavy et al., 2016). Participants in this study were asked to decide which of two mixtures of red and white paint drops (presented in Arabic numerals) was darker. The findings of this study suggested that intuitive automatic comparison of natural numbers supports or suppresses the comparison of ratios as a function of congruity and salience. These findings indicated that participants attend to and compare the natural numbers that comprise the ratios, as was found in previous behavioral and brain-imaging studies dealing with fractions (e.g., Bonato et al., 2007; Ischebeck et al., 2009; Kallai \& Tzelgov, 2009; Meert et al., 2009). Stavy and her colleagues (2016) suggested that interference of the intuitive automatic comparison of natural numbers when solving comparison of ratios problems might be reduced by directing students to choose an appropriate solution strategy, for example to calculate "rate per unit" ratios. Based on the problem-solving framework of executive functions (Zelazo et al., 1997), the current study aims to explore whether creating a different problem space that directs students to calculate "rate per unit" ratios in presentation of the task would improve their performance.

For the current study we designed two equivalent comparison of ratios tests. Both tests were presented nonsymbolically and were visually very similar. In one test, the Drops test, students were asked to compare the intensity of color of mixtures of red and white paint drops, i.e., to judge whether the right mixture was darker, the left mixture was darker, or the two mixtures were equally dark (as done previously by Stavy et al., 2016). In the second test, the Juice test, students were asked to compare the amount of juice each child receives when equally dividing the contents of cups of juice among children in each group, i.e., to judge whether the amount of juice each child in the right group receives is larger, the amount of juice each child in the left group receives is larger, or the amount of juice each child in both groups receives is equal. Figure 2 depicts equivalent trials (direct ratio) as presented in the Drops and Juice tests. The comparison of ratios task, when presented in the Juice test (Figure 2A), rather than in the Drops test (Figure 2B), is likely to direct students to calculate "rate per unit," thereby reducing the interference caused by the automatic comparison of natural numbers. This may improve students' performance in comparison of ratios trial types in which there is intuitive interference.

\section{A. Drops test}

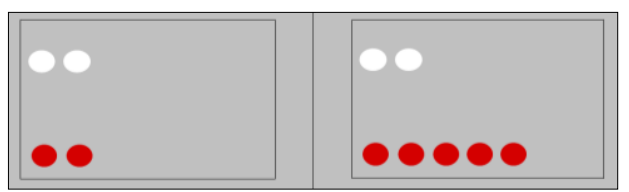

B. Juice test

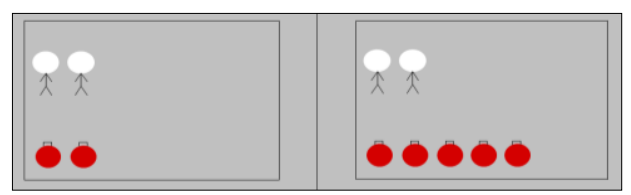

Figure 2. Equivalent comparison of ratios trials, presented in the Drops test (A) and in the Juice test (B)

It was previously suggested that both congruity and salience affect performance in comparison of ratios trials (Stavy et al., 2016). We therefore expected that the automatic comparison of natural numbers (e.g., number of red drops/juice cups) would interfere with proportional reasoning in the incongruent condition. In addition, we expect that decreasing the level of salience of the number of red drops/juice cups in the congruent condition will interfere with participants' performance in the task.

Figure 3 depicts the different trial types that were used in the current study (in the Drops test form).

With respect to congruity:

In congruent trials, in the Drops test, the mixture with the larger number of red drops is darker; in the Juice test, each child from the group that has a larger number of juice cups receives a larger amount of juice.

In incongruent trials, in the Drops test, the mixture with the larger number of red drops is equally as dark as the other; in the Juice test, each child from the group that has a larger number of juice cups receives an equal amount of juice as each child from the other group.

Comparison between congruent (Figure 3A) and incongruent (Figure 3B) trial types in each test will enable us to explore whether presenting the Juice test that directs students to calculate "rate per unit" ratios reduces the congruity effect and improves students' performance in incongruent trials. In order to explore the effect of congruity, in both congruent 
(Figure 3A) and incongruent (Figure 3B) conditions the level of salience is the same - emphasized salience (see below).

With respect to salience:

In congruent emphasized salience trials, in the Drops test, the difference in the number of red drops is larger than the difference in the number of white drops; in the Juice test, the difference in the number of juice cups is larger than the difference in the number of children.

In congruent nonemphasized salience trials, in the Drops test, the difference in the number of red drops is equal to the difference in the number of white drops; in the Juice test, the difference in the number of juice cups is equal to the difference in the number of children.

Decreasing the level of salience of the number of red drops/juice cups in the congruent condition, by making the difference between the number of red drops equal to the difference between the number of white drops (and likewise for juice cups and children) would not support the correct response and would probably interfere with participants' performance in the task.

Comparison between congruent emphasized (Figure 3A) and congruent nonemphasized (Figure $3 \mathrm{C}$ ) trial types in each test will enable us to explore whether presenting the Juice test that directs students to calculate "rate per unit" ratios reduces the salience effect and improves students' performance in the nonemphasized congruent trials. In order to explore the effect of salience, both emphasized and nonemphasized salience conditions are congruent.

It should be noted that it is irrelevant to include incongruent nonemphasized trials in our study, as answering such trials (e. g., 2 red, 2 white in Box A; 5 red, 5 white in Box B) does not actually require proportional reasoning.

The current study is based on the problem-solving framework of executive functions and on our view that students' difficulties may stem from intuitive interference of salient variables. The comparison of ratios task was presented in two modes of presentation that might lead to different problem spaces and hence direct different solution strategies. We hypothesized that a presentation mode that directed students to calculate "rate per unit" (the Juice test) would reduce the interference caused by the automatic comparison of natural numbers and result in better performance. In the current study we explored whether the Juice test would yield a higher success rate than would the Drops test among tenth graders. Moreover, following up on the recent study of Babai and his colleagues (2016), we investigated whether an intervention of previously performing the Juice test, which is visually very similar to the Drops test, would improve students' success in a subsequent Drops test.

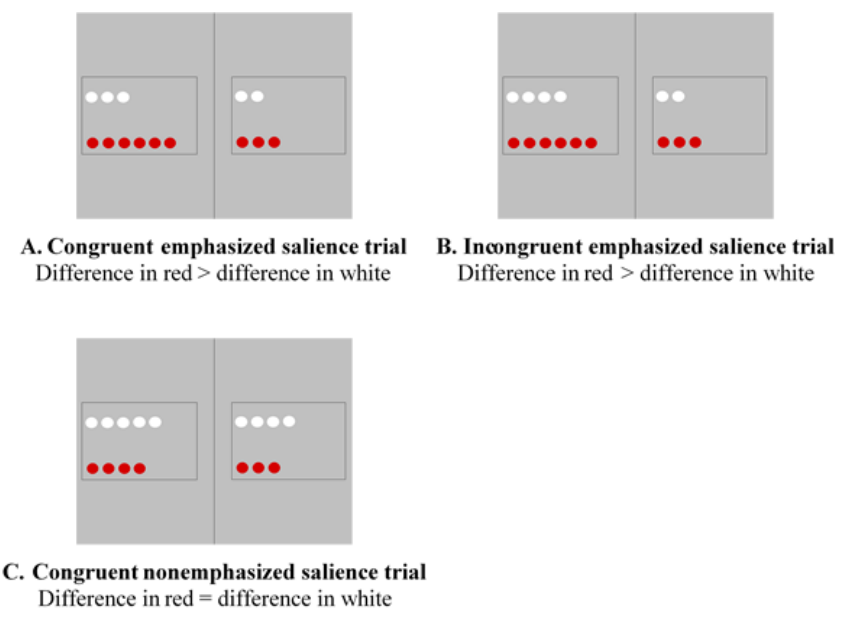

Figure 3. Examples of trial types used in the current study to explore effects of congruity (A vs. B) and salience (A vs. C) as presented in the Drops test

\section{Methodology}

\subsection{Participants}

A total of 69 tenth-grade students from one high school in central Israel were randomly assigned to the Drops and Juice tests (33 and 36 students participated in each of the tests, respectively). Students who performed the Drops test as a first test later performed the Juice test as a second test, and vice versa.

As mastering both direct and inverse ratio trial types is required for proportional reasoning, we included in the analysis students with accuracy of responses of $80 \%$ and above in both direct and inverse ratio trials in the first test. The final sample comprised 24 students who performed the Drops test as a first test (their mean accuracy for direct and inverse ratio trails was $93 \%$ and $94 \%$ respectively; mean RTC was 2530 and 3047 milliseconds respectively) and 25 students who performed the Juice test as a first test (their mean accuracy for direct and inverse ratio trails was $91 \%$ and $95 \%$ respectively; mean RTC was 2730 and 3351 milliseconds respectively).

\subsection{Comparison of ratios task-Drops test}

The computerized comparison of ratios reaction time task was presented in two modes, Drops test and Juice test, which were visually very similar (see Figure 2).

In the Drops test each trial presented two boxes on a grey background. Each box contained red and white circles representing, respectively, red and white paint drops. Participants were informed that in each box the drops of 
paint were mixed, and they were asked to compare the intensity of color in the resulting mixtures, i.e., to judge whether the right mixture was darker, the left mixture was darker, or the two mixtures were equally dark. Participants were asked to answer correctly and as rapidly as they could. Each trial was presented on the screen until the participant responded, "left mixture" by pressing the F-key, "right mixture" by pressing the J-key, or "equally dark" by pressing the space bar.

There were 30 relevant experimental trials in the test (15 pairs of ratios that were horizontally switched): 10 congruent emphasized salience, 10 incongruent emphasized salience, and 10 congruent nonemphasized salience (see Figure 3). In addition, there were 10 direct ratio and 10 inverse ratio trials (10 pairs of ratios that were horizontally switched). Success in these trials was used as a criterion to select the participants for analysis in the current study (see the Participants section). In addition, there were 30 irrelevant trials. These irrelevant trials belonged to conditions that were not analyzed as part of the current study (for example, trials that contained an equal number of red and white paint drops). The number of red and white paint drops in each mixture ranged from one to seven. The trials were presented on a computer screen in a pseudorandom order. At the start of the test, participants were presented with eight trials, different from the experimental ones, in order to familiarize them with the task and the experimental setting. Accuracy and reaction time were recorded for each response. Students who performed the Drops test as a first test later performed the Juice test.

\subsection{Comparison of ratios task-Juice test}

The Juice test was visually very similar to the Drops test (see Figure 2). Identical ratios were presented in both tests and shown in the same order. In the Juice test, students were asked to compare the amount of juice each child (depicted in white) receives when equally dividing the contents of cups of juice (depicted in red) to children in each group, i.e., to judge whether the amount of juice each child in the right group receives is larger, the amount of juice each child in the left group receives is larger, or the amount of juice each child in both groups receives is equal. As in the Drops test, in the Juice test participants were asked to answer correctly and as rapidly as they could. Each trial was presented on the screen until the participant responded, "left group" by pressing the F-key, "right group" by pressing the J-key, or "equal" by pressing the space bar. Likewise, at the start of the Juice test, participants were presented with eight trials, different from the experimental ones, in order to familiarize them with the task and the experimental setting. Accuracy and reaction time were recorded for each response. Students who performed the Juice test as a first test later performed the Drops test.

\subsection{Data analysis}

Accuracy was measured by calculating the percentages of correct responses for each participant for each test in each of the three conditions. The reaction time analysis consisted of calculating the average RTC for each participant for each test in each of the three conditions. Repeated measure General Linear Model (GLM) was carried out in SPSS software in order to detect significant differences. In Section 3.1 (effect of mode of presentation in the first test), the variables for effect of congruity were: mode of representation (Drops test and Juice test) and congruity (congruent emphasized salience and incongruent emphasized salience). For effect of salience, variables were: mode of representation (Drops test and Juice test) and salience (congruent emphasized salience and congruent nonemphasized salience). In Sections 3.2-3.3 (effect of previous mode of presentation) the variables were: previous mode of presentation (first or second test for either the Drops test or the Juice test) and either congruity (as above) or salience (as above).

\section{Results}

\subsection{Effect of mode of presentation in the first test}

We will first present the results related to the comparison of the two modes of presentation in the first test. We compared students' performance in the tests focusing on the effect of congruity (congruent vs. incongruent, both are emphasized salience trials) and salience (emphasized vs. nonemphasized salience, both are congruent trials).

Table 1 shows rate of success and RTC for the two modes of presentation, for the congruent and incongruent emphasized salience task conditions.

Table 1. Accuracy and reaction time of correct responses (RTC) in the first test of Drops $(n=24)$ and Juice $(n=25)$ for the congruent and incongruent emphasized salience trials

\begin{tabular}{|c|c|c|c|c|}
\hline \multirow[t]{2}{*}{ Congruity } & \multicolumn{2}{|c|}{$\begin{array}{c}\text { Accuracy in percent } \\
\text { (SD) }\end{array}$} & \multicolumn{2}{|c|}{$\begin{array}{l}\text { RTC in milliseconds } \\
\text { (SD) }\end{array}$} \\
\hline & Drops & Juice & Drops & Juice \\
\hline Congruent & $\begin{array}{l}87.5 \\
(15.1)\end{array}$ & $\begin{array}{l}86.8 \\
(11.1)\end{array}$ & $\begin{array}{c}2598 \\
(1224)\end{array}$ & $\begin{array}{c}4079 \\
(2140)\end{array}$ \\
\hline Incongruent & $\begin{array}{c}25.0 \\
(26.9)\end{array}$ & $\begin{array}{c}62.0 \\
(30.5)\end{array}$ & $\begin{array}{c}4567 \\
(1785)\end{array}$ & $\begin{array}{c}5049 \\
(1424)\end{array}$ \\
\hline
\end{tabular}

Analysis of success rate revealed statistically significant main effects of mode of presentation $(F=15.38, d f=47, p<.001$, partial eta squared $=0.247)$, and congruity $(F=97.15, d f=47$, $p<.001$, partial eta squared $=0.674)$. The success rate in the Juice test was higher than in the Drops test and was higher in congruent trials than in incongruent ones. In addition, a statistically significant interaction of mode of presentation $\mathrm{x}$ congruity $(F=18.12, \quad d f=47, \quad p<.001, \quad$ partial eta squared $=0.278$ ) was found. In the incongruent condition a higher success rate was found for the Juice test than for the 
Drops test (62\% vs. $25 \%$ ), while in the congruent no difference was observed (87\% vs. $88 \%)$.

Analysis of RTC included 14 participants in the Drops test and 23 participants in the Juice test. This analysis revealed statistically significant main effects of mode of presentation $(\mathrm{F}=4.62, d f=35, p=.039$, partial eta squared $=0.117)$, and congruity $(\mathrm{F}=13.64, \quad d f=35, \quad p=.001, \quad$ partial eta squared $=0.280$ ). This analysis revealed that RTC in incongruent trials was longer than that for congruent ones (4808 milliseconds vs. 3559 milliseconds) and was longer for the Juice test in comparison to the Drops test (4669 milliseconds vs. 3698 milliseconds).

Table 2 shows rate of success and RTC, for the two modes of presentation, for the emphasized and nonemphasized salience congruent task conditions.

Table 2. Accuracy and reaction time of correct responses (RTC) in the first test of Drops $(n=24)$ and Juice $(n=25)$ for the emphasized and nonemphasized salience congruent trials

\begin{tabular}{lcccc}
\hline \multirow{2}{*}{ Salience } & \multicolumn{2}{c}{$\begin{array}{c}\text { Accuracy in percent } \\
(\mathrm{SD})\end{array}$} & $\begin{array}{c}\text { RTC in milliseconds } \\
(\mathrm{SD})\end{array}$ \\
\hline & Drops & Juice & Drops & Juice \\
\cline { 2 - 5 } & 87.5 & 86.8 & 2598 & 4079 \\
Emphasized & $(15.1)$ & $(11.1)$ & $(1224)$ & $(2140)$ \\
& 38.8 & 55.6 & 5489 & 7149 \\
Nonemphasized & $(30.0)$ & $(25.8)$ & $(2685)$ & $(5583)$ \\
& & & & \\
\hline
\end{tabular}

Analysis of success rate revealed statistically significant main effect of salience $(F=92.14, d f=47, p<.001$, partial eta squared $=0.662$ ). The success rate was higher in emphasized congruent trials than in nonemphasized congruent ones. In addition, a statistically significant interaction of mode of presentation x salience $(\mathrm{F}=4.44, d f=47, p=.040$, partial eta squared $=0.086$ ) was found. In the nonemphasized congruent condition a higher success rate was found for the Juice test than for the Drops test (56 \% vs. $39 \%$ ), while in the emphasized congruent condition no difference was observed (87\% vs. $88 \%$ ).

Analysis of RTC included 20 participants in the Drops test and 24 participants in the Juice test. This analysis revealed that the effect of mode of presentation reached a significance level of $p=.075(F=3.33, d f=42$, partial eta squared $=0.074)$.

The analysis revealed a statistically significant main effect of salience $(F=22.80, \quad d f=42, \quad p<.001, \quad$ partial eta squared $=0.352$ ). This analysis revealed that RTC in nonemphasized congruent trials was longer than that for emphasized congruent ones (6319 milliseconds vs. 3424 milliseconds).
Overall, the above findings clearly indicate, as expected, that in both tests, congruity and salience affect student responses for both accuracy and RTC.

3.2 Drops test: Effect of previous mode of presentation on accuracy of responses and RTC

In this section we describe the accuracy and RTC of the Drops test administered as a first test to one group of students, and as a second test, administered after the Juice test, to a second group of students. The findings for congruent and incongruent emphasized salience trials are depicted in Table 3.

Table 3. Accuracy and reaction time of correct responses (RTC) in the Drops test presented as a first test to one group $(n=24)$ and as a second test to another group after performing the Juice test $(n=25)$ for the congruent and incongruent emphasized salience trials

\begin{tabular}{lcccc}
\hline \multirow{2}{*}{ Congruity } & \multicolumn{2}{c}{$\begin{array}{c}\text { Accuracy in percent } \\
\text { (SD) }\end{array}$} & \multicolumn{2}{c}{$\begin{array}{c}\text { RTC in milliseconds } \\
\text { (SD) }\end{array}$} \\
\hline \multirow{4}{*}{ Congruent } & $\begin{array}{c}\text { Drops as } \\
\text { first }\end{array}$ & $\begin{array}{c}\text { Drops } \\
\text { after Juice }\end{array}$ & $\begin{array}{c}\text { Drops as } \\
\text { first }\end{array}$ & $\begin{array}{c}\text { Drops } \\
\text { after Juice }\end{array}$ \\
\cline { 2 - 5 } & 87.5 & 87.2 & 2598 & 2731 \\
Incongruent & $(15.1)$ & $(15.4)$ & $(1224)$ & $(1255)$ \\
& 25.0 & 52.0 & 4567 & 4164 \\
& $(26.9)$ & $(32.2)$ & $(1785)$ & $(1426)$ \\
\hline
\end{tabular}

Analysis revealed statistically significant main effects of previous mode of presentation $(F=8.29, d f=47, p=.006$, partial eta squared $=0.150)$ and congruity $(F=98.85, d f=47$, $p<.001$, partial eta squared $=0.678)$. Success rate in the Drops test when following the Juice test was higher than that of Drops test as a first test (70 \% vs. $56 \%$, respectively) and is significantly higher in congruent than in incongruent trials ( $87 \%$ vs. $39 \%$, respectively). A statistically significant interaction of previous mode of presentation $\mathrm{x}$ congruity $(F=7.72, d f=47, p=.008$, partial eta squared $=0.141)$ was found. The improvement in success rate was only evident in incongruent trials (from $25 \%$ to $52 \%$ ).

Analysis of RTC included 14 participants in the Drops test as a first test and 24 participants in the drops test as a second test. This analysis revealed no statistically significant effects related to previous presentation mode; only main effect of congruity was observed $(\mathrm{F}=31.58, d f=36, p<.001$, partial eta squared $=0.467)$. RTC for incongruent trials was longer than that for congruent ones (4365 milliseconds vs. 2804 milliseconds).

The findings for emphasized and nonemphasized salience congruent trials of the Drops test administered as a first test to one group of students, and as a second test, administered after the Juice test, to a second group of students are depicted in Table 4. 
Table 4. Accuracy and reaction time of correct responses (RTC) in the Drops test presented as a first test to one group $(n=24)$ and as a second test to another group after performing the Juice test $(n=25)$ for the emphasized and nonemphasized salience congruent trials

\begin{tabular}{lcccc}
\hline Salience & \multicolumn{2}{c}{$\begin{array}{c}\text { Accuracy in percent } \\
\text { (SD) }\end{array}$} & $\begin{array}{c}\text { RTC in milliseconds } \\
(\mathrm{SD})\end{array}$ \\
\hline \multirow{4}{*}{ Emphasized } & $\begin{array}{c}\text { Drops as } \\
\text { first }\end{array}$ & $\begin{array}{c}\text { Drops } \\
\text { after Juice }\end{array}$ & $\begin{array}{c}\text { Drops as } \\
\text { first }\end{array}$ & $\begin{array}{c}\text { Drops } \\
\text { after Juice }\end{array}$ \\
\cline { 2 - 5 } & 87.5 & 87.2 & 2598 & 2731 \\
& $(15.1)$ & $(15.4)$ & $(1224)$ & $(1255)$ \\
Nonemphasized & 38.8 & 67.6 & 5489 & 4135 \\
& $(30.0)$ & $(23.9)$ & $(2685)$ & $(2002)$ \\
\hline
\end{tabular}

Analysis revealed statistically significant main effects of previous mode of presentation $(\mathrm{F}=9.09, d f=47, p=.004$, partial eta squared $=0.162)$ and salience $(F=69.01, d f=47$, $p<.001$, partial eta squared $=0.595$ ). Success rate in the Drops test when following the Juice test was higher than that in the Drops test as a first test (77\% vs. $63 \%$, respectively) and was significantly higher in emphasized than in nonemphasized congruent trials ( $87 \%$ vs. $53 \%$, respectively). A statistically significant interaction of previous mode of presentation x salience $(\mathrm{F}=12.55, d f=47, p=.001$, partial eta squared $=0.211$ ) was found. The improvement in success rate was only evident in nonemphasized congruent trials (from $39 \%$ to $68 \%$ ).

Analysis of RTC included 20 participants in the Drops test as a first test and 25 participants in the Drops test as a second test. This analysis revealed statistically significant main effect of salience $(F=53.78, \quad d f=43, \quad p<.001$, partial eta squared $=0.556$ ). RTC for nonemphasized trials was longer than that for emphasized congruent ones (4812 milliseconds vs. 2720 milliseconds). In addition, a statistically significant interaction of previous mode of presentation $\mathrm{x}$ salience $(F=5.80, d f=43, p=.020$, partial eta squared $=0.119)$ was found. RTC in nonemphasized trials was reduced from first to second test (5489 milliseconds vs. 4135 milliseconds), while no difference was observed for emphasized ones (2710 milliseconds vs. 2731 milliseconds).

\subsection{Juice test: Effect of previous mode of presentation on} accuracy of responses and RTC

In this section we describe the accuracy and RTC for the Juice test administered as a first test to one group of students, and as a second test, administered after the Drops test, to a second group of students. The findings for congruent and incongruent emphasized salience trials are depicted in Table 5.
Table 5. Accuracy and reaction time of correct responses (RTC) in the Juice test presented as a first test to one group $(n=25)$ and as a second test to another group after performing the Drops test $(n=24)$ for the congruent and incongruent emphasized salience trials

\begin{tabular}{lcccc}
\hline \multirow{2}{*}{ Congruity } & \multicolumn{2}{c}{$\begin{array}{c}\text { Accuracy in percent } \\
\text { (SD) }\end{array}$} & \multicolumn{2}{c}{$\begin{array}{c}\text { RTC in milliseconds } \\
\text { (SD) }\end{array}$} \\
\hline \multirow{4}{*}{ Congruent } & $\begin{array}{c}\text { Juice as } \\
\text { first }\end{array}$ & $\begin{array}{c}\text { Juice after } \\
\text { Drops }\end{array}$ & $\begin{array}{c}\text { Juice as } \\
\text { first }\end{array}$ & $\begin{array}{c}\text { Juice after } \\
\text { Drops }\end{array}$ \\
\cline { 2 - 5 } & 86.8 & 86.3 & 4079 & 3444 \\
& $(11.1)$ & $(15.6)$ & $(2140)$ & $(2077)$ \\
Incongruent & 62.0 & 45.1 & 5049 & 4728 \\
& $(30.5)$ & $(30.6)$ & $(1424)$ & $(2208)$ \\
\hline
\end{tabular}

Analysis of accuracy of responses revealed no statistically significant effects related to previous presentation mode; only main effect of congruity was observed $(F=49.82, d f=47$, $p<.001$, partial eta squared $=0.515$ ). Success rate is significantly higher in congruent than in incongruent trials ( $87 \%$ vs. $54 \%$, respectively). In contrast to the Drops test, in the Juice test (as a second test) no improvement in accuracy was evident in incongruent trials performed after the Drops test.

Analysis of RTC included 23 participants in the Juice test as a first test and 19 participants in the Juice test as a second test. This analysis revealed no statistically significant effects related to previous presentation mode; only main effect of congruity was observed $(F=7.31, d f=40, p=.010$, partial eta squared $=0.155)$. RTC for incongruent trials was longer than that for congruent ones (4889 milliseconds vs. 4052 milliseconds).

The findings for emphasized and nonemphasized salience congruent trials of the Juice test administered as a first test to one group of students, and as a second test, administered after the Drops test, to a second group of students are depicted in Table 6.

Table 6. Accuracy and reaction time of correct responses (RTC) in the Juice test presented as a first test to one group $(n=25)$ and as a second test to another group after performing the Drops test $(n=24)$ for the emphasized and nonemphasized salience congruent trials

\begin{tabular}{lcccc}
\hline \multirow{2}{*}{ Salience } & \multicolumn{2}{c}{$\begin{array}{c}\text { Accuracy in percent } \\
(\mathrm{SD})\end{array}$} & $\begin{array}{c}\text { RTC in milliseconds } \\
(\mathrm{SD})\end{array}$ \\
\hline \multirow{4}{*}{ Emphasized } & $\begin{array}{c}\text { Juice as } \\
\text { first }\end{array}$ & $\begin{array}{c}\text { Juice after } \\
\text { Drops }\end{array}$ & $\begin{array}{c}\text { Juice as } \\
\text { first }\end{array}$ & $\begin{array}{c}\text { Juice after } \\
\text { Drops }\end{array}$ \\
\cline { 2 - 5 } & 86.8 & 86.3 & 4079 & 3444 \\
& $(11.1)$ & $(15.6)$ & $(2140)$ & $(2077)$ \\
Nonemphasized & 55.6 & 45.8 & 7149 & 6582 \\
& $(25.8)$ & $(23.8)$ & $(5583)$ & $(4845)$ \\
\hline
\end{tabular}


Analysis of accuracy of responses revealed no statistically significant effects related to previous presentation mode; only main effect of salience was observed $(F=80.30, d f=47$, $p<.001$, partial eta squared $=0.631$ ). Success rate was significantly higher in emphasized than in nonemphasized congruent trials ( $87 \%$ vs. $51 \%$, respectively). In contrast to the Drops test, in the Juice test (as a second test) no improvement in accuracy was evident in nonemphasized salient trials performed after the Drops test.

Analysis of RTC included 24 participants in the Juice test as a first test and 12 participants in the Juice test as a second test. This analysis revealed no statistically significant effects related to previous presentation mode; only main effect of salience was observed $(F=17.19, d f=44, p<.001$, partial eta squared $=0.281$ ). RTC for nonemphasized trials was longer than that for emphasized ones (6866 milliseconds vs. 3866 milliseconds).

\section{Discussion}

The current study is based on the problem-solving framework of executive function, specifically on the first step of constructing a problem space (Zelazo et al., 1997). The problem space is the representation of the problem and its possible solutions. Therefore, a different problem space could be constructed when presenting a problem in a different mode. Choosing a specific mode of presentation may lead to construction of a different problem space that might suggest appropriate solution strategies and thus help solvers in overcoming difficulties. Our study illustrates how executive functions are involved in problem solving related to proportional reasoning.

Proportional reasoning, an important skill in school and in daily life, is known to be difficult for schoolchildren and adults (e.g., Karplus et al., 1983). We focused here on a comparison of ratios task known to be difficult for many students due to the interference of the automatic comparison of the salient natural numbers that comprise the ratios. Such interference was previously reported based on behavioral and fMRI brainimaging studies (e.g., Ischebeck et al., 2009; Kallai \& Tzelgov, 2009; Meert et al., 2009; Stavy et al., 2016). Based on the problem-solving framework of executive functions we expected that using two different presentations of the comparison of ratios task would lead to different solution strategies. We designed two nonsymbolically equivalent comparison of ratios tasks that were visually very similar, the Drops test and the Juice test. The Juice test (Figure 2A), in comparison to the Drops test (Figure 2B), was aimed at creating a problem space that directed students to calculate "rate per unit," thereby reducing the interference of the automatic comparison of the salient natural numbers.

We studied here whether the Juice test would yield a higher success rate than would the Drops test among tenth graders. We also explored whether performing the Juice test before the Drops test would improve students' success in the Drops test. Findings of the current study indicate that, indeed, success in the Juice test is higher than in the Drops test, for both incongruent emphasized salience and congruent nonemphasized salience trials. Moreover, success in these conditions in the Drops test is higher when performed after the Juice test. Below we discuss our findings related to the effect of mode of presentation in the first test and the effect of previous presentation mode.

\subsection{Effect of mode of presentation in the first test}

Previous studies in science and mathematics education have suggested that specific modes of presentation improve students' performance (e.g., Clement, 1993; Elia et al., 2007; Martin \& Schwartz, 2014; Tirosh \& Tsamir, 1996; Tsamir, 2003). Findings of the current study clearly show that success rate in the Juice test is significantly higher than in the Drops test for trials in which interference caused by the automatic comparison of natural numbers is evident, i.e., incongruent emphasized trials and congruent nonemphasized ones. The Juice test probably leads to a problem space that directs students to apply more complex, time consuming, appropriate strategies, such as calculation of per unit ratios (i.e., dividing juice from cups among groups of children). In the Drops test, however, no hints to such strategies of calculating per unit ratios are given and students who rely on the salient numbers of drops tend to provide more incorrect responses. The findings suggest that the Juice test results in an overall longer RTC (for the salience effect, statistical significance level is $p=.075$ ), indicating that the solution strategies for the Juice test are more complex.

It should be noted that although performance is much higher in the Juice test, effects of both congruity and salience are still evident, indicating that intuitive interference continues to affect students' reasoning even when their performance is improved.

\subsection{Effect of previous presentation mode}

Success rate for the Juice test was higher than for the Drops test when each was presented as a first test. Comparing the Drops test before and after performing the Juice test indicated that students' success rate in the Drops test is higher after performing the Juice test, while students' success rate in the Juice test is not higher when performed after the Drops test.

These findings suggest that the problem space constructed in the Juice test is later used when performing the Drops test. This transfer probably stems from the visual similarity between the two tests. Further studies are needed in order to explore the importance of visual similarity for transfer of appropriate solution strategies.

\section{Conclusions}

The current study provides some practical implications for education. For example, educators could consider using modes of presentations that lead to problem spaces that would direct students to use appropriate solution strategies 
that will aid them in overcoming difficulties. Using modes or orders of presentation could serve as important tools for educators of science and mathematics and could lead to higher academic achievements of students in science and mathematics.

The positive effect of a previous presentation mode observed in the current study can be seen as "teaching by analogy." In teaching by analogy students are first presented with an "anchoring task" that elicits a correct response due to the way it is presented, thus supporting appropriate solution strategies. Later on, students are presented with a similar "target task" known to elicit incorrect responses. The anchoring task probably encourages appropriate solution strategies, and such a sequence of instruction is effective in helping students overcome difficulties (e.g., Babai et al., 2016; Clement, 1993; Stavy, 1991; Tsamir, 2003). Further exploration through brain imaging of the brain correlates of such an intervention and studying long-term effects and possible behavioral effects in different populations (e.g., different ages, various mathematical competencies) would be beneficial.

\section{Acknowledgments}

This research was supported by the Israel Science Foundation [grant no. 464/07].

\section{References}

Babai, R., Brecher, T., Stavy R., \& Tirosh, D. (2006). Intuitive interference in probabilistic reasoning. International Journal of Science and Mathematics Education, 4(4), 627639. https://doi.org/10.1007/s10763-006-9031-1

Babai, R., Nattiv, L., \& Stavy, R. (2016). Comparison of perimeters: Improving students' performance by increasing the salience of the relevant variable. ZDM Mathematics Education, 48(3), 367-378.

https://doi.org/10.1007/s11858-016-0766-z

Bonato, M., Fabbri, S., Umiltà, C., \& Zorzi, M. (2007). The mental representation of numerical fractions: Real or integer? Journal of Experimental Psychology: Human Perception and Performance, 33(6), 1410-1419. https://doi.org/10.1037/0096-1523.33.6.1410

Clement, J. (1993). Using bridging analogies and anchoring intuitions to deal with students' preconceptions about physics. Journal of Research in Science Teaching, 30(10), 1241-1257. https://doi.org/10.1002/tea.3660301007

Dehaene, S. (2011). The number sense: How the mind creates mathematics, revised and updated edition. New York, NY: Oxford University Press.

Elia, I., Gagatsis, A., \& Demetriou, A. (2007). The effects of different modes of representation on the solution of onestep additive problems. Learning and Instruction, 17(6), 658-672. https://doi.org/10.1016/j.learninstruc.2007.09.011
Fischbein, E. (1987). Intuition in science and mathematics. Dordrecht, The Netherlands: Reidel.

Gómez, D. M., Jiménez, A., Bobadilla, R., Reyes, C., \& Dartnell, P. (2015). The effect of inhibitory control on general mathematics achievement and fraction comparison in middle school children. ZDM Mathematics Education, 47(5), 801-811. https://doi.org/10.1007/s11858-0150685-4

Green, D. R. (1983). A survey of probabilistic concepts in 3000 students aged 11-16 years. In D. R. Grey, P. Holmes, V. Barnett, \& G. M. Constable (Eds.), Proceedings of the First International Conference on Teaching Statistics (pp. 766783). Sheffield, UK: Teaching Statistics Trust.

Inhelder, B., \& Piaget, J. (1958). The growth of logical thinking: From childhood to adolescence. New York, NY: Basic Books.

Ischebeck, A., Schocke, M., \& Delazer, M. (2009). The processing and representation of fractions within the brain: An fMRI investigation. NeuroImage, 47(1), 403-413. https://doi.org/10.1016/j.neuroimage.2009.03.041

Kallai, A. Y., \& Tzelgov, J. (2009). A generalized fraction: An entity smaller than one on the mental number line. Journal of Experimental Psychology: Human Perception and Performance, 35(6), 1845-1864. https://doi.org/10.1037/a0016892

Karplus, E., Pulos, S., \& Stage, E. K. (1983). Proportional reasoning of early adolescents. In R. Lesh \& M. Landau (Eds.), Acquisition of mathematics concepts and processes (pp. 45-90). New York, NY: Academic Press.

Lamon, S. J. (2007). Rational numbers and proportional reasoning: Toward a theoretical framework for research. In F. Lester (Ed.), Second handbook of research on mathematics teaching and learning (pp. 629-668). Reston, VA: NCTM.

Martin, L., \& Schwartz, D. L. (2014). A pragmatic perspective on visual representation and creative thinking. Visual Studies, 29(1), 80-93. https://doi.org/10.1080/1472586x.2014.862997

Meert, G., Grégoire, J., \& Noël, M.-P. (2009). Rational numbers: Componential versus holistic representation of fractions in a magnitude comparison task. Quarterly Journal of Experimental Psychology, 62(8), 1598-1616 https://doi.org/10.1080/17470210802511162

Moss, J., \& Case, R. (1999). Developing children's understanding of the rational numbers: A new model and an experimental curriculum. Journal for Research in Mathematics Education, 30(2), 122-147. https://doi.org/10.2307/749607

Ni, Y., \& Zhou, Y. D. (2005). Teaching and learning fraction and rational numbers: The origins and implications of whole number bias. Educational Psychologist, 40(1), 27-52. https://doi.org/10.1207/s15326985ep4001_3 
Noelting, G. (1980a). The development of proportional reasoning and the ratio concept (the Orange Juice Experiment), Part 1: The determination of stages. Educational Studies in Mathematics, 11(2), 217-253. https://doi.org/10.1007/bf00304357

Noelting, G. (1980b). The development of proportional reasoning and the ratio concept, Part 2: Problem structure at successive stages; problem-solving strategies and the mechanism of adaptive restructuring. Educational Studies in Mathematics, 11(3), 331-363. https://doi.org/10.1007/bf00697744

Reiss, M., Behr, M., Lesh, R., \& Post, T. (1985). Cognitive processes and products in proportional reasoning. In $\mathrm{L}$. Streefland (Ed.), Proceedings of the Ninth International Conference for the Psychology of Mathematics Education (pp. 352-356). Noordwijkerhout (Utrecht), Netherlands: PME.

Siegler, R. S. (1976). Three aspects of cognitive development. Cognitive Psychology, 8(4), 481-520. https://doi.org/10.1016/0010-0285(76)90016-5

Stavy, R. (1991). Using analogy to overcome misconceptions about conservation of matter. Journal of Research in Science Teaching, 28(4), 305-313. https://doi.org/10.1002/tea.3660280404

Stavy, R., \& Babai, R. (2010). Overcoming intuitive interference in mathematics: Insights from behavioral, brain imaging and intervention studies. ZDM Mathematics Education, 42(6), 621-633. https://doi.org/10.1007/s11858-010-0251-z

Stavy, R., \& Babai, R. (2008). Complexity of shapes and quantitative reasoning in geometry. Mind, Brain, and Education, 2(4), 170-176. https://doi.org/10.1111/j.1751228x.2008.00051.x
Stavy, R., Babai, R., \& Kallai, A. Y. (2016). Proportional reasoning: The role of congruity and salience in behavioral and imaging research. Zeitschrift für Psychologie, 224(4), 266-276. https://doi.org/10.1027/2151-2604/a000262

Stavy, R., \& Berkovitz, B. (1980). Cognitive conflict as a basis for teaching quantitative aspects of the concept of temperature. Science Education, 64(5), 679-692. https://doi.org/10.1002/sce.3730640514

Stavy, R., \& Tirosh, D. (2000). How students (mis-)understand mathematics and science. New York, NY: Teachers College Press.

Tirosh, D., \& Tsamir, P. (1996). The role of representations in students' intuitive thinking about infinity. International Journal of Mathematical Education in Science and Technology, 27(1), 33-40. https://doi.org/10.1080/0020739960270105

Tsamir, P. (2003). From "easy" to "difficult" or vice versa: The case of infinite sets. Focus on Learning Problems in Mathematics, 25(2), 1-17.

Vamvakoussi, X., Van Dooren, W., \& Verschaffel, L. (2012). Naturally biased? In search for reaction time evidence for a natural number bias in adults. The Journal of Mathematical Behavior, 31(3), 344-355. https://doi.org/10.1016/j.jmathb.2012.02.001

Zelazo, P. D., Carter, A., Reznick, J. S., \& Frye, D. (1997). Early development of executive function: A problem-solving framework. Review of General Psychology, 1(2), 198-226. https://doi.org/10.1037/1089-2680.1.2.198 


\title{
EXPERIMENTAL RESEARCH
}

\section{Executive function as a predictor of physics-related conceptual change}

\author{
François Thibault ${ }^{1 *} \&$ Patrice Potvin ${ }^{1}$
}

\begin{abstract}
While expert vs. novice comparisons using fMRI revealed a link between executive function and expertise in scientific fields such as electricity and mechanics, it is still uncertain whether these functions are active components of the learning process, rather than its by-product. Using the Force Concept Inventory to track conceptual change, the aim of this study was to confirm that executive function is indeed relevant to this process. Data suggests that participants with higher executive function abilities, as approximated by the Wisconsin Card Sorting Test, are likely to make more progress toward conceptual changes in a 15-week physics course than participants with lesser abilities. This implies that executive function is solicited throughout the process of conceptual change, and not solely being used as a consequence of expertise.
\end{abstract}

\footnotetext{
${ }^{1}$ Université du Québec à Montréal, Faculty of Education Sciences, Department of Didactics, Montreal, Canada

*Author email address: thibault.francois.2@uqam.ca
}

To cite this article: Thibault, F., \& Potvin, P. (2018). Executive function as a predictor of physics-related conceptual change. Neuroeducation, 5(2), 119-126.

DOI: https://doi.org/10.24046/neuroed.20180502.119

Received on November $30^{\text {th }}, 2017$. Received in revised form on May $30^{\text {th }}, 2018$.

Accepted on June $9^{\text {th }}, 2018$. Available online on September $19^{\text {th }}, 2018$.

Neuroeducation, 5(2), 119-126

ISSN: 1929-1833

All rights reserved (C) 2018 - Association for Research in Neuroeducation 


\section{Introduction}

The development of modern imaging technology, combined with its ever-increasing availability, has allowed researchers to study the human brain for purposes that are not medical in nature. This led to interesting discoveries in educational research, bringing valuable insights to fields such as language and mathematics education. Scientific education, on the other hand, has yet to see similar progress.

Up to now, a significant part of imaging research in this field has focused on comparisons between novices and experts in different areas of science, a trend largely influenced by Dunbar and his team's work on this topic (Dunbar \& Stein, 2007). In their initial publication, they describe an experiment comparing experts and novices in mechanics, where it was observed that for experts to answer successfully to items related to a common misconception (heavier objects fall faster than lighter ones), increased activation of the anterior cingulate cortex $(\mathrm{ACC})$ was required.

In the past, many functions have been attributed to the ACC: target selection (Frith et al., 1991; Posner et al., 1988), motivational valence assessment (Mesulam, 1990), motor response selection (Badgaiyan \& Posner, 1998; Paus et al., 1993; Turken \& Swick, 1999), error detection (Gehring \& Knight, 2000; Luu, Flaisch \& Tucker, 2000), competition monitoring (Carter et al., 1998), working memory (Petit et al., 2000) and reward assessment (Knutson et al., 2000). More recently, its activation has been described as some sort of "teaching signal" indicating that the situation leading to its activation requires increased cognitive resources to process, and thus should preferably be avoided in the future (Botvinick, 2007). Activation of the ACC is also observed during tasks such as the Stroop Task (Adleman et al., 2002; Bush et al., 1998) or the Wisconsin Card Sorting Test (Lie et al., 2006) suggesting that it could be linked to executive functions such as inhibition and shifting, and possibly also updating, considering its previously observed ties to working memory.

Using a nearly identical task involving the common physics misconception that heavier objects fall faster, Brault Foisy, Masson, Potvin, \& Riopel (2013) replicated Dunbar \& Stein's (2007) findings and effectively observed an increased activation of the ACC for experts viewing non-scientific events. Furthermore, activation of the left dorsolateral prefrontal cortex (DLPFC) and the right ventrolateral prefrontal cortex (VLPFC), regions commonly associated with executive functions such as inhibition, working memory and set-shifting (Bush et al., 1998; Lie et al., 2006; Menon et al., 2001; Monchi et al., 2001; NathanielJames, Fletcher, \& Frith, 1997) were recorded alongside the ACC, which could be interpreted as a sign that non-scientific events trigger misconceptions even in experts, who are then able to overcome them and consistently produce correct answers during the task. Identical activation patterns were also observed by Masson, Potvin, Riopel, \& Brault Foisy (2014) using a similar methodology, but with regards to a common misconception in electricity according to which a single wire connecting a light bulb to a power source is required for it to produce light.
However, such experiments can only account for what happens during task-specific activities. In other words, while they can tell us about the differences between experts' and novices' performances during specific problem-solving tasks, they tell us nothing about how said experts developed their expertise in the first place. As such, before these findings can significantly impact scientific education in general, additional information is required. Since these experiments focus on specific misconceptions, the "experts" that are being studied are generally described as having completed a successful conceptual change, meaning that they have permanently overcome the interference caused by the misconception, and can be reliably expected to answer correctly during the task. This leads to an interesting question: are executive functions part of the process of conceptual change, or is their increased use by experts merely a consequence of the conceptual changes they have completed?

Insights towards an answer to this question can be found in Kwon \& Lawson's (2000) study of the effect of brain growth on scientific reasoning and conceptual change. Using a modified version of Lawson's Classroom Test of Scientific Reasoning (Lawson, 1978, 1987, 1992), they found that inhibition capacity, as measured by the Wisconsin Card Sorting Test (WCST; Berg, 1948; Heaton et al., 1993) was, of all other variables considered, the best predictor of scientific reasoning. Furthermore, scientific reasoning was also revealed as the best predictor of post-test performance on a test of air pressure concepts. These results coincide with the recent fMRI studies described earlier, in that they confirm that thinking like a scientist, and thus successfully solving scientific problems, seems to involve the use of executive functions such as inhibition.

The primary focus of their experiment, however, was to learn more about conceptual change. More specifically, it was to learn which functions of a teenager's developing brain were more important in improving conceptual understanding regarding various air pressure concepts. Defining conceptual gain as the difference between pre- and post-test results on a test of air pressure concepts (i.e., students' scores improve because they progress toward conceptual change regarding some of the concepts studied over the 14 weeks of the experiment), the authors found that inhibition capacity was also the best predictor of conceptual change, more so than other variables such as scientific reasoning, mental capacity or planning ability. As such, inhibition appears to not only be important for problem solving in science-related domains, but also for achieving conceptual change in these domains.

But while these results were very promising at the time, more recent knowledge raises doubts as to what was really observed during Kwon \& Lawson's (2000) experiment. Knowing that performance to science-related tasks is strongly linked to executive functions, and that these functions, as demonstrated by Kwon and Lawson themselves using the WCST, vary greatly with age, the extended duration of their experiment can be problematic. Indeed, it is not 
impossible that participants achieved better results on the post-test, not because they learned the targeted concepts, but rather because their executive function abilities improved during the experiment, allowing them to perform better. Furthermore, the lessons that covered air-pressure concepts in this study specifically used the concept acquisition test questions as examples, giving partial credit for answers that were conceptually insufficient, but used the correct terminology. As such, it is difficult to conclude with certainty that conceptual change truly occurred, as opposed to simple memorization of previously unknown key terms.

This distinction between conceptual change and memorization is deeply tied to the Piagetian paradigm (Piaget, 1952), which describes two main forms of learning: assimilation and accommodation. In Posner, Strike, Hewson, \& Gertzog's (1982) conceptual change model, assimilation is described as a "simple" accretion of knowledge, while accommodation requires profound changes in the learner's conceptions, a consequence of the incongruities between their prior conceptions and newly acquired knowledge. Assimilation and accommodation have also respectively been described as requiring weak and strong restructuring (Carey, 1985; Tyson et al., 1997), highlighting the inherent difficulties associated with acquiring new knowledge when prior conceptions act as a source of interference.

Such interference also explains the previously described observations, where executive functions such as inhibition were required to perform science-related tasks involving common misconceptions. Indeed, it could be argued that such observations are required to conclude that the strong restructuring associated with conceptual change has occurred or, perhaps more importantly, is in the process of occurring. In this context, a confirmation that executive functions are solicited during the process of conceptual change, and not simply manifested during problem resolution once conceptual change has been completed, is required before pursuing other objectives, such as identifying which executive functions are in play and the extent of their influence on this process. To do so, the current study will use a methodology very similar to Kwon \& Lawson's (2000), but controlling for variations in executive function capacities, as well as using stricter instruments to measure conceptual change over the experimental period.

\section{Method}

\subsection{Sample}

Participants $(n=59)$ were recruited among first-year students at École de Technologie Supérieure (ETS), one of Montreal's two engineering universities. To be selected, participants had to be registered for the ING150 course during the semester in which the study took place. This is an introductory level course on Newtonian mechanics and is mandatory for first-year students of all engineering specializations at ÉTS. It is also important to note that ÉTS students are selected from technical college programs rather than pre-university college programs, and that the participants were mostly enrolled in software and electrical engineering programs. Consequently, their only prior Newtonian mechanics training took place roughly three to four years prior to this study, while most of them were still in high school.

\subsection{Design}

Prior to instruction, students were administered pre-test measures of executive function (Wisconsin Card Sorting Test) and force-related knowledge (Force Concept Inventory). These tests were administered using the Laboratoire mobile pour l'étude des cheminements d'apprentissage (LabMÉCAS), a portable laboratory consisting of 35 laptop computers preloaded with testing software. This allowed the students to take the tests during their scheduled directed exercise period and required a total of approximately 45 minutes for both tests.

After pre-testing, students were taught a series of 15 threehour lessons in Newtonian mechanics at a rate of one lesson per week during a 15-week semester, supplemented by another 15 three-hour sessions of directed exercises. Although students were selected in three different groups, all three lecturers responsible for their instruction were required by ÉTS to adhere strictly to the standard curriculum for the ING150 course. After completion of the lessons, both the Wisconsin Card Sorting Test and the Force Concept Inventory were re-administered to participants in the last regularly scheduled directed exercise period prior to the final examination for the course.

\subsection{Materials}

\subsubsection{Wisconsin Card Sorting Test}

As per Kwon and Lawson's (2000) research, the WCST was used to measure participants' executive function. Although this test was initially designed to measure mental flexibility (Berg, 1948), it is also known to require increased activation from the dorsolateral prefrontal cortex and the anterior cingulate cortex (Lie et al., 2006; Monchi et al., 2001), brain regions that are often associated with the inhibition of incorrect responses (Konishi et al., 1999; Taylor et al., 1997), detection of dissonance between observations and expectations (Berns, Cohen, \& Mintun, 1997; Carter et al., 1998), as well as task-set switching (Aron, Robbins, \& Poldrack, 2004). As such, it should serve as a good approximation of executive function in general.

This test consists of a total of 132 cards: 4 stimulus cards and 128 response cards. Each of these cards can be described using three different characteristics: number, shape and colour. During the test, the participant is asked to successively match each of the response cards to one of the stimulus cards. After each attempt, the participant is told whether the match is correct or not, but not the matching principle. Once 10 consecutive correct matches are made, the 
matching principle is changed. While the participant has been warned that the matching principle will change during the test, the required conditions, as well as the algorithm used to select matching principles, remain unknown to them. When a participant, after receiving negative feedback, persists in using a discarded principle for their attempts, they are said to have committed a perseveration error and are assigned -1 points. Thus, participants with higher executive function capabilities will also have higher scores (i.e., closer to 0).

It should also be noted that the WCST measures executive function in a context where visual stimulation is preponderant, which could be problematic if the other variable studied is not visual in nature. Indeed, it has been observed in the past that executive functions such as inhibition can be highly task-dependent (Simmonds, Pekar, \& Mostofsky, 2008). As such, a general approximation of executive function should be more accurate if it uses stimuli that are similar in nature to the other elements being studied. This should not be an issue in the current experiment, however, as visual elements such as graphs or other schematic representations are very often used in mechanics, but also in scientific education in general. There is thus no reason to believe that the WCST would perform differently in experiments involving other scientific domains.

Furthermore, in concordance with the need to ensure that variations in performance were not due to unexpected variations in executive function, steps were taken to control for pre- to post-test variations in executive function abilities. Specifically, executive function abilities were calculated by taking each participant's average score on the WCST, and then disqualifying participants whose deviation (the difference between their actual WCST scores and their calculated average) were more than two standard deviations removed from the average deviation of the studied sample.

Indeed, while a certain increase in WCST scores could be expected as students learn to inhibit their misconceptions, it would be very unusual for a participant to be among the best during one iteration of the test and among the worse during the other. This had the unfortunate side effect of considerably reducing the number of eligible participants (from 59 to 52), negatively impacting the precision of the intended statistical analyses, but also ensuring that any correlation observed between executive function abilities and conceptual change could not be attributed to extreme variations in WCST scores. The typical scenario for these rejected participants was to have a nearly perfect score (fewer than 10 perseveration errors) in either the pre- or the post-test, and abnormally low scores in the other (over 30 perseveration errors). In contrast, the average participant saw their WCST score improve by 1.36 points $(\sigma=3.07)$.

\subsubsection{Force Concept Inventory}

To measure participants' comprehension of force-related concepts, the Force Concept Inventory (FCI) test was used. Specifically designed by physics professors based on their observations of common students' misconceptions (Halloun
\& Hestenes, 1985; Hestenes, Wells \& Swackhamer, 1992), the FCI is a multiple-choice questionnaire consisting of 30 items. For each item, a single correct answer and four distractors are presented to participants. One of the key points of this test is that each of the distractors is based on one of the most popular misconceptions about forces. There are no calculations required to answer the FCI's items. Rather, participants are asked to interpret or describe a specific phenomenon by selecting the appropriate answer.

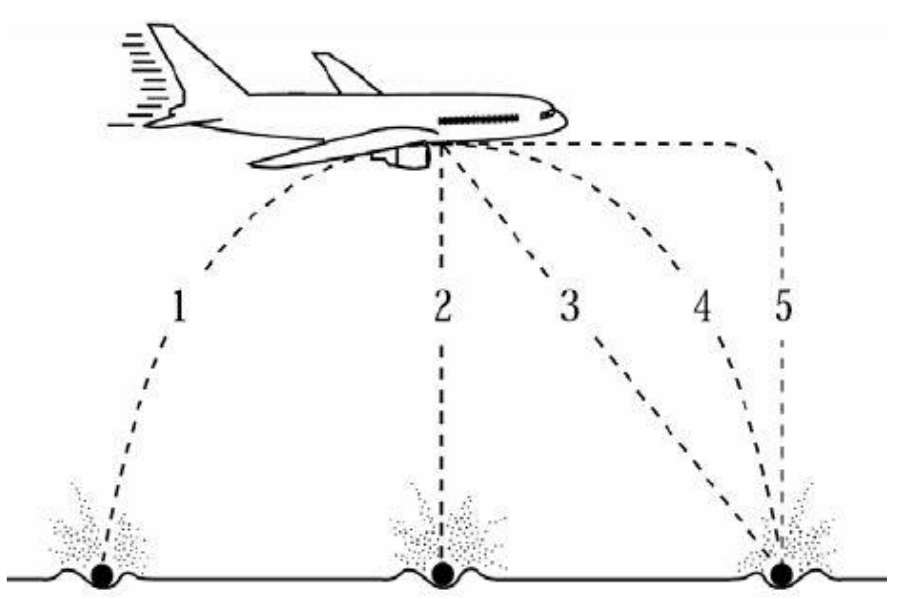

Figure 1. Sample item from the FCI (Hestenes et al., 1992)

Figure 1 shows one such item, where the participant is asked to pick which trajectory would best describe the path of a bowling ball dropped from a plane that is moving toward the right at a constant velocity. Option \#1 is based on a misconception that can arise after watching video footage of parachute jumpers. In videos taken from a point of view inside the plane, the jumper seems to fall backwards, causing the misconception. Option \#2 is based on more mundane sources: in their daily lives, people often drop items, which apparently fall in a straight line toward the ground. This is because the slow speed of a walking human, combined with the relatively low height at which the object is held, makes it very hard to notice the small forward movement. Option \#3 is caused by partial comprehension of the phenomenon. While proponents of this answer understand that the plane imparts a certain velocity toward the right to the bowling ball, they fail to consider that gravity imparts an acceleration, and not a fixed velocity, toward the ground. Similarly, option \#5 describes the Aristotelian theory of impetus, intuitively held by many, where the forward momentum must be "spent" before the ball can fall to the ground. Thus, only participants who truly understand the difference between velocity and acceleration, as well as being able to correctly identify the forces at play and the initial conditions of the bowling ball, are able to answer correctly using option \#4.

A similar design was used for each of the 30 items of the Force Concept Inventory. Since every distractor is designed to appeal to participants who hold specific misconceptions, only those who have completed conceptual change toward the 
selected concepts should be able to consistently answer correctly.

While Kwon \& Lawson (2000) also correlated post-test scores to executive function, the current study will focus solely on pre- to post-test gains on the FCI. Indeed, correlation between post-test results and executive function could be explained, as was previously described during the short review of more recent fMRI studies, by the fact that executive function correlates with performance in science-related tasks. As such, pre- to post-test gains constitute the best measure of conceptual change during the experimental period, especially given the specific nature of the FCI's items.

\subsection{Instrumentation}

For this study, a computerized version of the WCST was used. It is available on the Psychology Experiment Building Language (PEBL) platform and conforms to Berg's (1948) original implementation of the test in every way, except for the fact that feedback is given automatically by the program and not by a human agent. As for the FCI, a French version of the test was administered using an interactive Portable Document Format file. Thanks to the LabMÉCAS infrastructure, it was possible for up to 34 participants to take the tests simultaneously, a process requiring approximately one hour.

\section{Results}

Table 1 presents descriptive statistics of participants' results on the Force Concept Inventory, as well as the average class grade for the ING150 course. As it can be observed, despite having achieved generally good grades on the ING150 course, participants show a limited understanding of concepts related to force, velocity and acceleration. In fact, their conceptual understanding only seems to have minimally improved during the semester, the average gain on the FCI only being 1.96 out of 30 items.

Table 1. Descriptive statistics for the FCI and ING150 course

\begin{tabular}{lccc}
\hline & $\begin{array}{c}\text { FCI pre-test } \\
(/ 30)\end{array}$ & $\begin{array}{c}\text { FCI post-test } \\
(/ 30)\end{array}$ & FCI Gain \\
\cline { 2 - 4 } Average & 12.83 & 14.79 & 1.96 \\
Minimum & 4 & 3 & -5 \\
Q1 & 9 & 11 & 1 \\
Median & 11 & 14 & 2 \\
Q3 & 17 & 18 & 3 \\
Maximum & 25 & 28 & 9 \\
\hline ING150 course average & $81 \%$ & & \\
\hline
\end{tabular}

Figure 2 shows a graph of pre- to post-test gains on the FCI as a function of inhibiting ability. Regression analysis shows that a moderate $(.30<\mathrm{R}=.427<.50$ [Cohen, 1988]) positive correlation $(p<.01)$ exists between participants' inhibiting ability and their ability to successfully achieve conceptual change, as measured by their FCI gains over one semester. Furthermore, although there seems to be little variation in inhibiting ability for the majority of participants, this variable explains $18.2 \%$ of the variance observed for pre- to post-test gains, as can be observed in Table 2 .

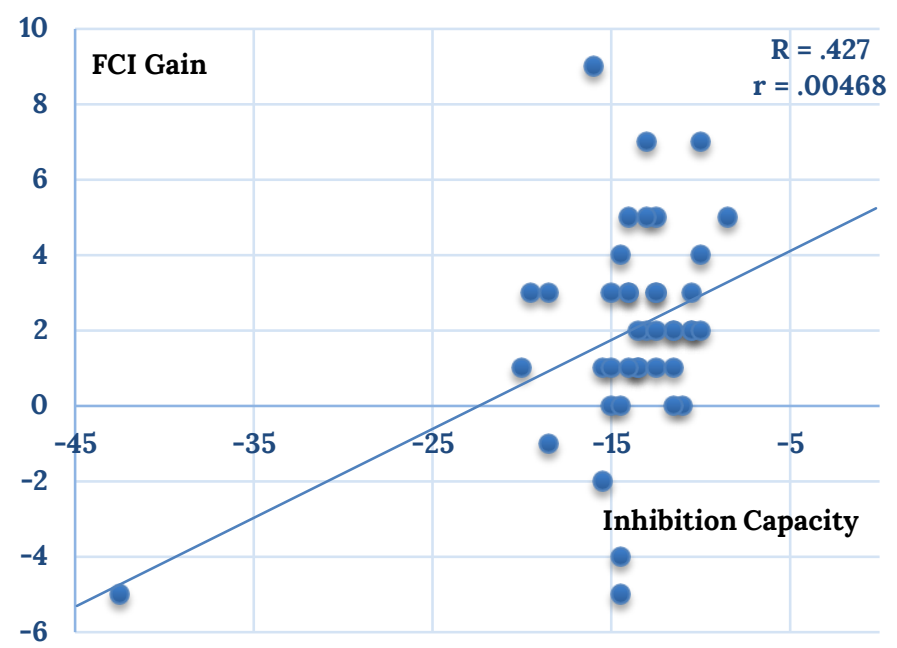

Figure 2. FCI Gain vs. Inhibition Capacity

However, the presence of several outliers on the graph warrants the use of non-parametric measures, such as Spearman's and Kendall's rank correlation coefficients. This is due to the fact that the calculations involved in statistical analyses such as Pearson's coefficient use the data itself, meaning that extreme outliers will have a larger impact on the end result than other points of data. Spearman's and Kendall's coefficients do not suffer from this bias, as they use each participant's rank for each variable rather than the actual test scores. Using these measures, a positive correlation $(p<.05)$ can still be observed, although its effect seems to be slightly weaker than what Pearson's coefficient seems to indicate $(\rho=.308, \tau=.228)$.

Table 2. Correlation Analysis

\begin{tabular}{ll}
\hline Pearson's correlation coefficient $(\mathrm{R})$ & .427 \\
Squared Pearson $\left(\mathrm{R}^{2}\right)$ & .182 \\
$p\left(\mathrm{R}^{2}\right)$ & .00468 \\
Spearman's rank correlation coefficient $(\rho)$ & .308 \\
$p(\rho)$ & .0469 \\
Kendall rank correlation coefficient $(\tau)$ & .228 \\
$p(\tau)$ & .0474 \\
\hline
\end{tabular}




\section{Discussion}

Interestingly, participants seem to have become adept at solving problems related to forces, as shown by their class' generally strong results on the ING150 course, despite their limited understanding of the related concepts, as evidenced by their results on the FCI (as shown in Table 1). This could be tied to the ÉTS's vocation as an engineering school, where more emphasis is placed on practical problem solving over conceptual understanding. It would have been interesting to compare participants' grades to the class average, but the ÉTS decided not to disclose individual grades for ethical reasons.

As can be seen in Figure 2, most of the participants seem to possess very similar inhibiting abilities, which can most likely be explained by the selection process used by ÉTS during student admission. Indeed, similarly to medical programs, engineering programs in Quebec require college grades that are well above average, and enrollment is limited. As such, it is not impossible that participants in the current sample, despite holding common misconceptions in force-related physics, are on the stronger side of the executive function spectrum.

This could possibly explain the large difference between the present correlation and the one observed by Kwon and Lawson (2000), for whom inhibiting ability could explain nearly $30 \%$ of the variance in conceptual gains. There are also large differences in the tests administered to the participants in both studies to measure conceptual gains. While the 30 FCI items all contained "traps" based on popular misconceptions and were meant to lure participants into selecting the wrong answers, the test used by Kwon and Lawson consisted of only six open-ended short answer questions where partial points could be awarded to participants who correctly used certain keywords while still answering incorrectly overall. This has the effect of allowing students to score better on the test despite not necessarily having completed conceptual change, allowing for a wider distribution of scores in the sample. Furthermore, the lessons given to participants in Kwon and Lawson's study specifically included the different test items and the corresponding answers as examples which, combined with the scoring method used, could have allowed students to achieve better gains than expected.

Additional correlation analysis using Spearman's rank correlation coefficient reveals that, while the outliers had an obvious impact on the observed correlation ( $\rho=.308$ vs. $\mathrm{R}=.427)$, the correlation still exists $(p<.05)$. Unlike Pearson's coefficient, Spearman's Rho does not assume that the relationship between the two variables is linear in nature (Hauke \& Kossowski, 2011). As such, its value should not be interpreted as a strength of the correlation, but rather as an indication of how well an arbitrary monotonic function could describe the association between the variables. Using this non-parametric measure, it is thus possible to conclude that a modest, but significant, relationship exists between measured executive function and conceptual change as measured by the FCI, whereas participants with higher scores on the WCST also tended to learn more during the same physics course.

Another interesting interpretation of the data stems from the use of Kendall's rank correlation coefficient, which is a measure of the concordance between the subjects' rankings according to both studied variables. Using the calculated coefficient, it can be inferred that, when comparing two students, the one possessing higher executive function abilities also has a $61.4 \%$ chance of achieving more conceptual gains during the semester. These odds, while not overwhelming, are consistent with the moderate effect observed with Pearson's and Spearman's coefficients.

\section{Conclusion}

Novice vs. Expert comparisons using fMRI initially revealed a link between executive function and performance in sciencerelated tasks. In these studies, experts showed increased brain activation in areas linked to executive function such as the anterior cingulate cortex, the left ventrolateral prefrontal cortex or the right dorsolateral prefrontal cortex when successfully solving tasks involving common misconceptions. This link has also been observed in studies using reaction times, where participants required more time to process similar items, which authors explained by the solicitation of increased cognitive resources required by common misconceptions portrayed in the task (Potvin et al., 2014; Shtulman \& Valcarcel, 2012).

The data collected during this research extends these findings, supporting the existence of a relation between executive function and conceptual change. While the sample size is small, significant correlations were found between the two variables using three different correlation coefficients. In short, these results imply that students with stronger executive function abilities will tend to be more efficient at achieving conceptual change in domains rich in misconceptions. These results should in no way be interpreted as meaning that these students should be favoured or that science programs be restricted to them as they are most likely to succeed, especially since the correlation is only of moderate strength. Rather, teachers and educators might be interested in helping students develop their executive function alongside the traditional curriculum, as this could potentially make them more efficient at successfully completing conceptual change in the future. Furthermore, tests of executive function could be used as a diagnostic tool to identify the students that are more likely to struggle with the standard curriculum and adjust their instruction accordingly.

But before researching pedagogical practices that favour the development of executive function, it would be important to establish which specific executive functions are being solicited. Indeed, many executive functions, such as inhibition, working memory and set-shifting, are linked to similar brain activity when tested using fMRI (Aron et al., 2004; Berns et al., 1997; Carter et al., 1998; Konishi et al., 1999; 
Taylor et al., 1997), meaning that distinguishing one from the other using only fMRI data is not easy, especially if the task was not specifically designed to measure executive function. In turn, knowing which specific executive functions are at play during the process of conceptual change would give researchers and educators new insights regarding the effectiveness of various teaching methods, ideally leading to better learning opportunities for students.

\section{References}

Adleman, N. E., Menon, V., Blasey, C. M., White, C. D., Warsofsky, I. S., Glover, G. H., \& Reiss, A. L. (2002). A developmental fMRI study of the Stroop color-word task. NeuroImage, 16(1), 61-75. https://doi.org/10.1006/nimg.2001.1046

Aron, A. R., Robbins, T. W., \& Poldrack, R. A. (2004). Inhibition and the right inferior frontal cortex. Trends in Cognitive Sciences, 8(4), 170-177. https://doi.org/10.1016/j.tics.2004.02.010

Badgaiyan, R. D., \& Posner, M. I. (1998). Mapping the cingulate cortex in response selection and monitoring. NeuroImage, 7(3), 255-260. https://doi.org/10.1006/nimg.1998.0326

Berg, E. A. (1948). A simple objective technique for measuring flexibility in thinking. The Journal of General Psychology, 39(1), 15-22. https://doi.org/10.1080/00221309.1948.9918159

Berns, G. S., Cohen, J. D., \& Mintun, M. A. (1997). Brain regions responsive to novelty in the absence of awareness. Science, 276(5316), 1272-1275.

https://doi.org/10.1126/science.276.5316.1272

Botvinick, M. M. (2007). Conflict monitoring and decision making: Reconciling two perspectives on anterior cingulate function. Cognitive, Affective, \& Behavioral Neuroscience, 7(4), 356-366.

https://doi.org/10.3758/cabn.7.4.356

Brault Foisy, L.-M., Masson, S., Potvin, P., \& Riopel, M. (2013, June). Using fMRI to compare cerebral activations between novices and experts in science during a task in mechanics involving a common misconception. Paper presented at the Canada-Israel Symposium on Brain Plasticity, Learning and Education, Western University, London, Canada.

Bush, G., Whalen, P. J., Rosen, B. R., Jenike, M. A., McInerney, S. C., \& Rauch, S. L. (1998). The counting Stroop: an interference task specialized for functional neuroimaging-validation study with functional MRI. Human Brain Mapping, 6(4), 270-282. https://doi.org/10.1002/(sici)10970193(1998)6:4\%3C270::aid-hbm6\%3E3.3.co;2-h

Carey, S. (1985). Conceptual change in childhood. Cambridge, MA: MIT Press.
Carter, C. S., Braver, T. S., Barch, D. M., Botvinick, M. M., Noll, D., \& Cohen, J. D. (1998). Anterior cingulate cortex, error detection, and the online monitoring of performance. Science, 280(5364), 747-749. https://doi.org/10.1126/science.280.5364.747

Cohen, J. (1988). Statistical power analysis for the behavioral sciences ( $2^{\text {nd }}$ ed.). Hillsdale, NJ: Erlbaum.

Dunbar, K. N., \& Stein, C. (2007). Do naïve theories ever go away? In Lovett (Ed.), Thinking with data (pp.193-205), Mahwah, NJ: Lawrence Erlbaum Associates.

Frith, C. D., Friston, K. J., Liddle, P. F., \& Frackowiak, R. S. (1991). Willed action and the prefrontal cortex in man: A study with PET. Proceedings of the Royal Society of London. Series B: Biological Sciences, 244(1311), 241-246. https://doi.org/10.1098/rspb.1991.0077

Gehring, W. J., \& Knight, R. T. (2000). Prefrontal-cingulate interactions in action monitoring. Nature Neuroscience, 3(5), 516-520. https://doi.org/10.1038/74899

Halloun, I. A., \& Hestenes, D. (1985). The initial knowledge state of college physics students. American Journal of Physics, 53(11), 1043-1055. https://doi.org/10.1119/1.14030

Hauke, J., \& Kossowski, T. (2011). Comparison of values of Pearson's and Spearman's correlation coefficients on the same sets of data. Quaestiones Geographicae, 30(2), 8793. https://doi.org/10.2478/v10117-011-0021-1

Heaton, R. K., Chelune, G. J., Tally, J. L., Kay, G. G., \& Curtiss, G. (1993). Wisconsin Card Sorting Test manual: Revised and expanded. Odessa, FL: Psychological Assessment Resources, Inc.

Hestenes, D., Wells, M. \& Swackhamer, G. (1992). Force Concept Inventory. The Physics Teacher, 30(3), 141-158. https://doi.org/10.1119/1.2343497

Konishi, S., Nakajima, K., Uchida, I., Kikyo, H., Kameyama, M. \& Miyashita, Y. (1999). Common inhibitory mechanism in human inferior prefrontal cortex revealed by eventrelated functional MRI. Brain, 122(5), 981-991. https: //doi.org/10.1093/brain/122.5.981

Knutson, B., Westdorp, A., Kaiser, E., \& Hommer, D. (2000). FMRI visualization of brain activity during a monetary incentive delay task. NeuroImage, 12(1), 20-27. https://doi.org/10.1006/nimg.2000.0593

Kwon, Y.-J., Lawson, A. E. (2000). Linking brain growth with the development of scientific reasoning ability and conceptual change during adolescence. Journal of Research on Science Teaching, 37(1), 44-62. https://doi.org/10.1002/(sici)10982736(200001)37:1\%3C44::aid-tea4\%3E3.0.co;2-j

Lawson, A. E. (1992). What do tests of formal reasoning actually measure? Journal of Research in Science Teaching, 29(9), 965-983. https://doi.org/10.1002/tea.3660290906 
Lawson, A. E. (1987). Classroom Test of scientific reasoning. Unpublished manuscript, Arizona State University, Tempe, Arizona.

Lawson, A. E. (1978). The development and validation of a classroom test of formal reasoning. Journal of Research in Science Teaching, 15(1), 11-24.

https://doi.org/10.1002/tea.3660150103

Lie, C. H., Specht, K., Marshall, J. C., \& Fink, G. R. (2006). Using fMRI to decompose the neural processes underlying the Wisconsin Card Sorting Test. NeuroImage, 30(3), 10381049. https://doi.org/10.1016/j.neuroimage.2005.10.031

Luu, P., Flaisch, T., \& Tucker, D. M. (2000). Medial frontal cortex in action monitoring. Journal of Neuroscience, 20(1), 464-469. https://doi.org/10.1523/jneurosci.2001-00464.2000

Masson, S., Potvin, P., Riopel, M., \& Brault-Foisy, L.-M. (2014). Differences in brain activation between novices and experts in science during a task involving a common misconception in electricity. Mind, Brain, and Education, 8(1), 44-55. https://doi.org/10.1111/mbe.12043

Menon, V., Adleman, N. E., White, C. D., Glover, G. H., \& Reiss, A. L. (2001). Error-related brain activation during a Go/NoGo response inhibition task. Human Brain Mapping, 12(3), 131-143. https://doi.org/10.1002/10970193(200103)12:3\%3C131::aid-hbm1010\%3E3.0.co;2-c

Mesulam, M. (1990). Large-scale neurocognitive networks and distributed processing for attention, language, and memory. Annals of Neurology, 28(5), 597-613. https://doi.org/10.1002/ana.410280502

Monchi, O., Petrides, M., Petre, V., Worsley, K., \& Dagher, A. (2001). Wisconsin Card Sorting revisited: distinct neural circuits participating in different stages of the task identified by event-related functional magnetic resonance imaging. The Journal of Neuroscience, 21(19), 7733-7741. https://doi.org/10.1523/jneurosci.21-19-07733.2001

Nathaniel-James, D. A., Fletcher, P., \& Frith, C. D. (1997). The functional anatomy of verbal initiation and suppression using the Hayling Test. Neuropsychologia, 35(4), 559-566. https://doi.org/10.1016/s0028-3932(96)00104-2

Paus, T., Petrides, M., Evans, A. C., \& Meyer, E. (1993). Role of the human anterior cingulate cortex in the control of oculomotor, manual, and speech responses: a positron emission tomography study. Journal of Neurophysiology, 70(2), 453-469. https://doi.org/10.1152/jn.1993.70.2.453
Petit, L., Courtney, S. M., Ungerleider, L. G., \& Haxby, J. V. (1998). Sustained activity in the medial wall during working memory delays. The Journal of Neuroscience, 18(22), 9429-9437. https://doi.org/10.1523/jneurosci.18-22-09429.1998

Piaget, J. (1952). The origin of intelligence in children. New York, NY: International Universities Press.

Posner, M. I., Petersen, S., Fox, P., \& Raichle, M. (1988). Localization of cognitive operations in the human brain. Science, 240(4859), 1627-1631. https://doi.org/10.1126/science.3289116

Posner, G. J., Strike, K. A., Hewson, P. W., \& Gertzog, W. A. (1982). Accommodation of a scientific conception: Toward a theory of conceptual change. Science Education, 66(2), 211-227. https://doi.org/10.1002/sce.3730660207

Potvin, P., Masson, S., Lafortune, S., \& Cyr, G. (2014). Persistence of the intuitive conception that heavier objects sink more: A reaction time study with different levels of interference. International Journal of Science and Mathematics Education, 13(1), 21-43. https://doi.org/10.1007/s10763-014-9520-6

Simmonds, D. J., Pekar, J. J., \& Mostofsky, S. H. (2008). Metaanalysis of $\mathrm{Go} / \mathrm{No}$-go tasks demonstrating that fMRI activation associated with response inhibition is taskdependent. Neuropsychologia, 46(1), 224-232. https://doi.org/10.1016/j.neuropsychologia.2007.07.015

Shtulman, A., \& Valcarcel, J. (2012). Scientific knowledge suppresses but does not supplant earlier intuitions. Cognition, 124(2), 209-215.

https://doi.org/10.1016/j.cognition.2012.04.005

Taylor, S. F., Kornblum, S., Lauber, E. J., Minoshima, S., \& Koeppe, R. A. (1997). Isolation of specific interference processing in the Stroop task: PET activation studies. NeuroImage, 6(2), 81-92. https://doi.org/10.1006/nimg.1997.0285

Turken, U., \& Swick, D. (1999). Response selection in the human anterior cingulate cortex. Nature Neuroscience, 2(10), 920-924. https://doi.org/10.1038/13224

Tyson, L. M., Venville, G. J., Harrison, A. G., \& Treagust, D. F. (1997). A multidimensional framework for interpreting conceptual change events in the classroom. Science Education, 81(4), 387-404. https://doi.org/10.1002/(sici)1098237x(199707)81:4\%3C387::aid-sce2\%3E3.0.co;2-8 